\title{
PEDRO TUMA
}
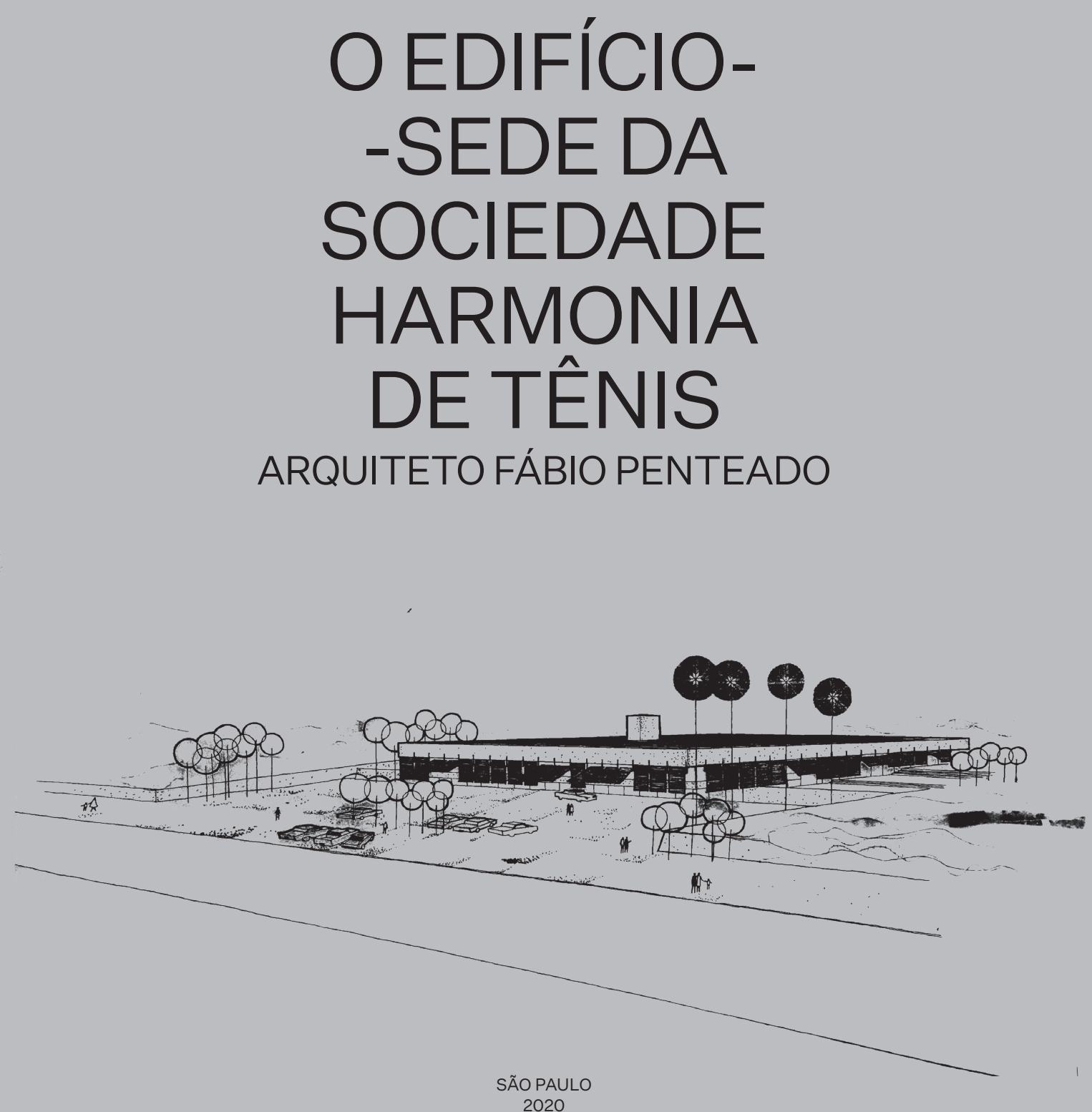



\section{Pedro Tuma}

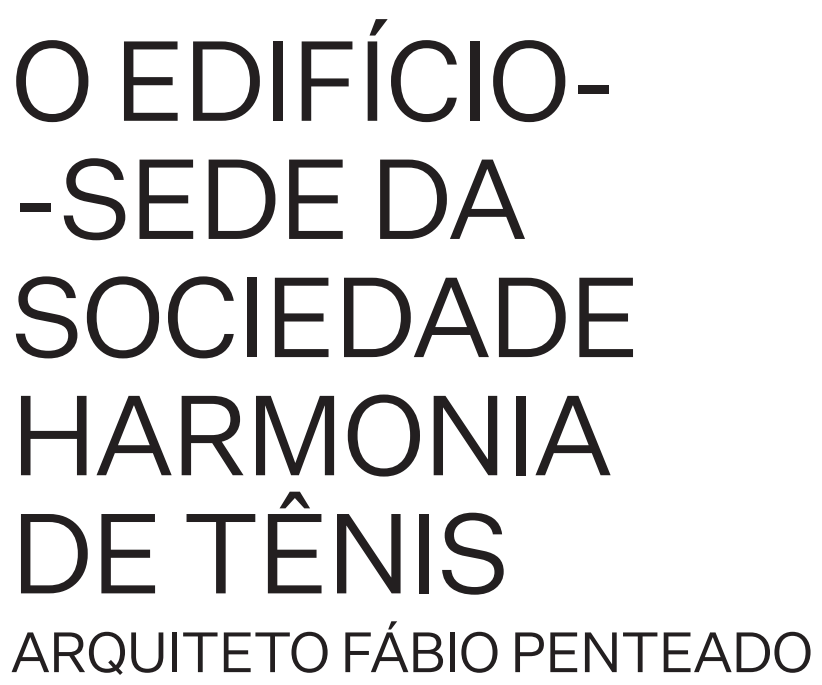

Dissertação apresentada à Faculdade de Arquitetura e

Urbanismo da Universidade de São Paulo para a obtenção

do título de Mestre em Arquitetura e Urbanismo.

Área de Concentração:

Projeto de Arquitetura

Orientador:

Profa. Dra. Helena A. Ayoub Silva

Exemplar corrigido em relação à versão original,

sob responsabilidade do autor e anuência da orientadora.

A versão original, em formato digital, ficará arquivada na

Biblioteca da Faculdade. 
Autorizo a reprodução e divulgação total ou parcial deste trabalho, por qualquer meio

convencional ou eletrônico, para fins de estudo e pesquisa, desde que citada a fonte.

Email do autor: pedro@terraetuma.com.br

Faculdade de Arquitetura e Urbanismo da Universidade de São Paulo

Tuma, Pedro

O edifício-sede da Sociedade Harmonia de Tênis: Arquiteto Fábio Penteado / Pedro Tuma; orientadora Helena Aparecida Ayoub Silva. - São Paulo, 2020. $130 \mathrm{p}$.

Dissertação (Mestrado) - Faculdade de Arquitetura e Urbanismo da Universidade de São Paulo. Área de concentração: Projeto da Arquitetura.

1. Penteado, Fábio Moura. 2. Arquitetura Moderna - São Paulo. 3. Arquitetura Moderna - Brasil. 4. Clubes Esportivos. I. Silva, Helena Aparecida Ayoub, orient. II. Título. 


\section{Pedro Tuma}

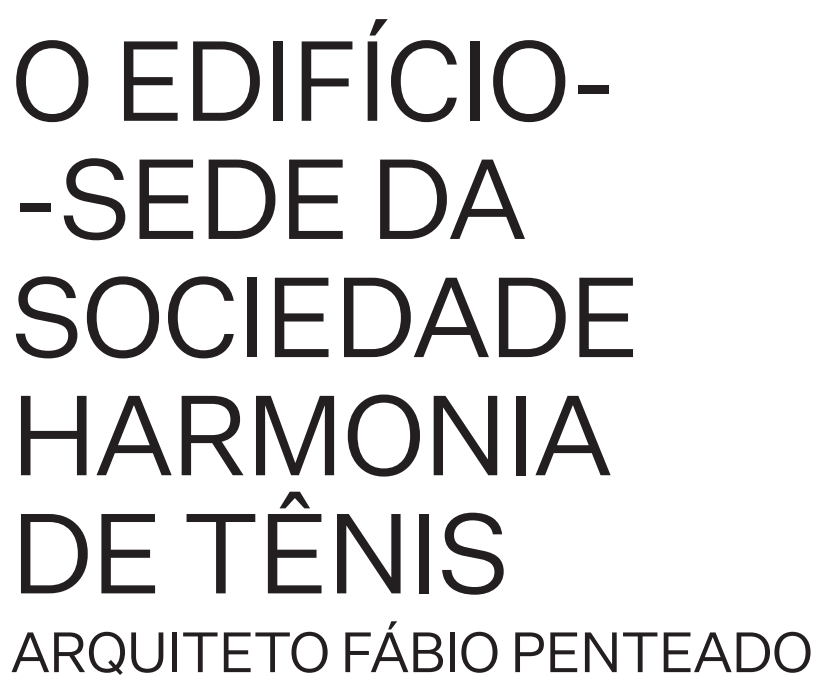

Dissertação apresentada à Faculdade de Arquitetura e

Urbanismo da Universidade de São Paulo para a obtenção

do título de Mestre em Arquitetura e Urbanismo.

Aprovado em:

Banca Examinadora

Profa. Dra

Instituição:

Julgamento:

Assinatura:

Prof. Dr.

Instituição:

Julgamento:

Assinatura:

Prof. Dr.

Instituição:

Julgamento

Assinatura: 
O edifício-sede da Sociedade Harmonia de Tênis, projetado por Fábio Penteado, Alfredo Paesani e Teru Tamaki em 1964, se enquadra entre os edifícios mais representativos produzidos pela vanguarda da arquitetura moderna paulista.

Projetado sob os paradigmas que uniam a vanguarda paulista e a mais alta tecnologia do concreto armado disponível na época, o edifício tem uma qualidade construtiva exemplar e se encontra em bom estado de conservação e originalidade, incentivado pelo tombamento do CONDEPHAAT no ano de 1992.

Este trabalho busca resgatar os antecedentes históricos formadores desta vanguarda e, a partir de uma análise centrípeta em relação ao edifício-sede, revelar aproximações e distanciamentos entre as demais obras modernas produzidas até aquele momento.

Palavras-chave:1. Penteado, Fábio Moura. 2. Arquitetura Moderna - São Paulo. 3. Arquitetura Moderna - Brasil. 4. Clubes Esportivos.
The headquarters building of Sociedade Harmonia de Tênis, designed by Fábio Penteado, Alfredo Paesani and Teru Tamaki in 1964, is one of the most representative buildings produced by the avant-garde of modern São Paulo architecture.

Designed under the paradigms that united the vanguard of São Paulo and the highest technology of reinforced concrete available at the time, the building has an exemplary constructive quality and is in good condition and originality, encouraged by the tipping of CONDEPHAAT in 1992.

This work seeks to rescue the historical antecedents that formed this avant-garde and, from a centripetal analysis in relation to the headquarters building, to reveal approximations and distances between the other modern works produced up to that moment.

Keywords: 1. Penteado, Fábio Moura 2. Modern Architecture - São Paulo. 3. Modern Architecture - Brazil. 4. Sports clubs. 


\section{AGRADECIMENTOS}

Arquivo Fábio Penteado

Biblioteca da Escola da Cidade

Biblioteca da Faculdade de Arquitetura e Urbanismo

da Universidade de São Paulo

Biblioteca do IEB - Instituto de Estudos Brasileiros

Centro Cultural São Paulo

Instituto Moreira Salles

Japan House São Paulo

Aos meus filhos Bento Ornaghi Tuma e Caetano Ornaghi Tuma pelo apoio irrestrito e compreensão da minha ausência.

A minha orientadora Helena Ayoub e minha companheira Fernanda Lie Sakano que tornaram esta pesquisa possível.

Aos meus familiares Eliana Berdugo, Gabriella Ornaghi, Caio Tuma, Mariana Tuma e aos sócios Danilo Terra e Juliana Assali.

Aos amigos Cesar Shundi Iwamizu e Francesco Perrotta-Bosch pelas conversas iniciais.

À equipe do Arquivo Fábio Penteado, Adriana Penteado, César Sampedro, Renata Baralle e Caio Sertori.

Bárbara Catta - projeto gráfico e diagramação

Clovis Pacheco Filho - revisão

Isabella Finholdt - digitalização dos slides

Aos professores Antônio Carlos Barossi, Hugo Segawa, Leandro Medrano, Mônica Junqueira Camargo, Marta Bogéa, Rafael Perrone.

Aos parceiros Rafael Murolo e Mariana Viegas.

Ao jornalista Paulo Markun e aos pesquisadores Ivo Giroto e Vitor Próspero. 

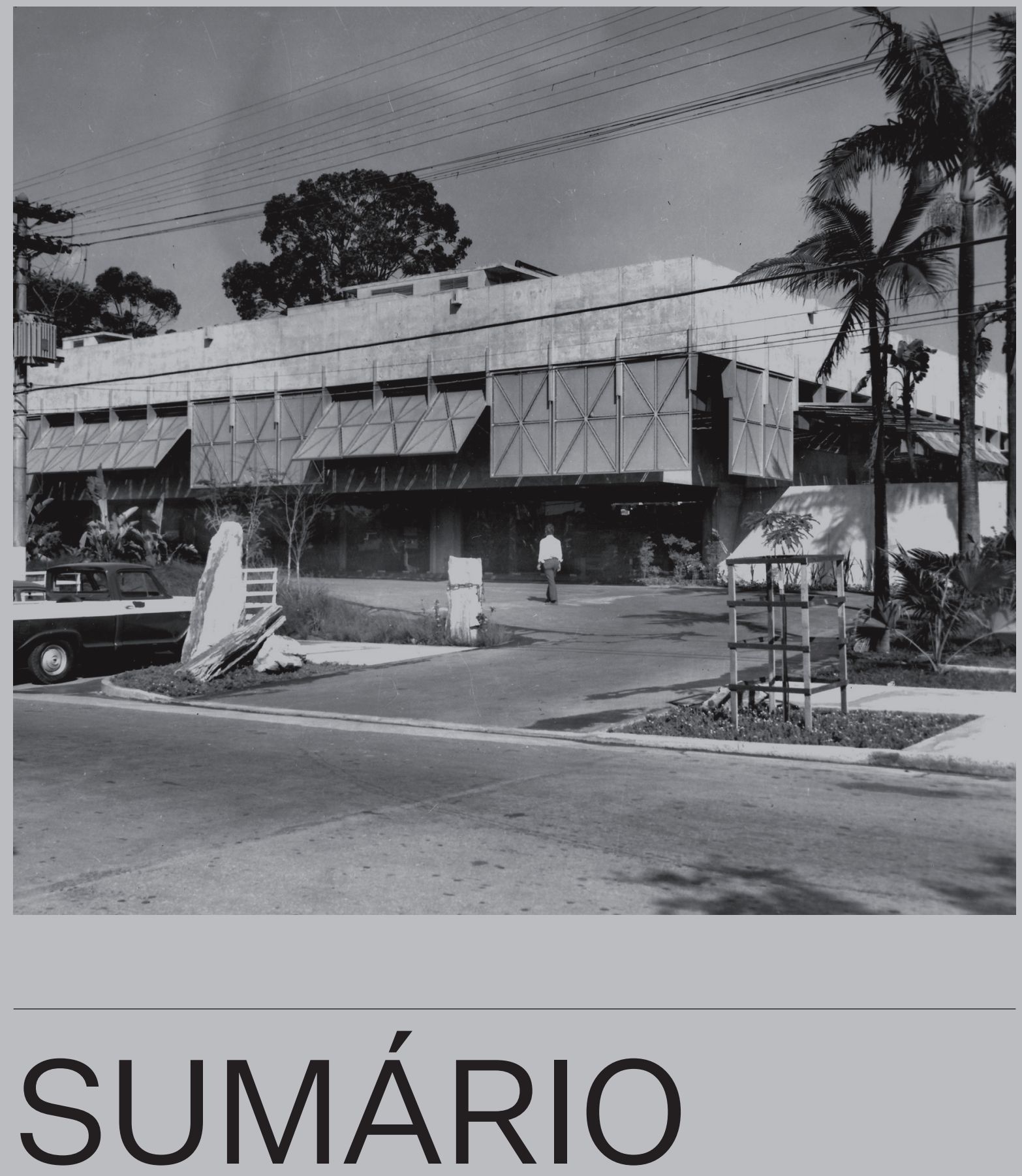


\section{INTRODUÇÃO}

\section{CONTEXTO \\ HISTÓRICO}

POLÍTICA NACIONAL-DESENVOLVIMENTISTA NO BRASIL

ESCOLA CARIOCA

VANGUARDA MODERNA PAULISTA

CLUBES ESPORTIVOS

NOTAS 1

\section{ANTECEDENTES}

AUTORES DO PROJETO 


\section{PROJETOS}

CONCURSO DE 1958

CONCURSO DE 1964

ANTEPROJETO DE 1964 - 1 a VERSÃO

ANTEPROJETO DE 1964 - 2a VERSÃO

DESENVOLVIMENTO DOS PROJETOS E OBRA

Contrato

Projetos Executivos

Estrutura

Águas Pluviais

95

Iluminação

95

Acústica

96

Estudo de cores

96

Mobiliário

98

RELAÇÃO COM A PAISAGEM

101

A PRAÇA COBERTA

103

COBERTURA ÚNICA E OS PLANOS DE LAJES

108

REDESENHO DA TOPOGRAFIA

FORMA DE EXCEÇÃO

\section{CONSIDERAÇÕES \\ FINAIS}

122

\section{REFERÊNCIAS \\ BIBLIOGRÁFICAS}

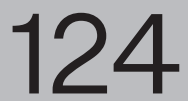




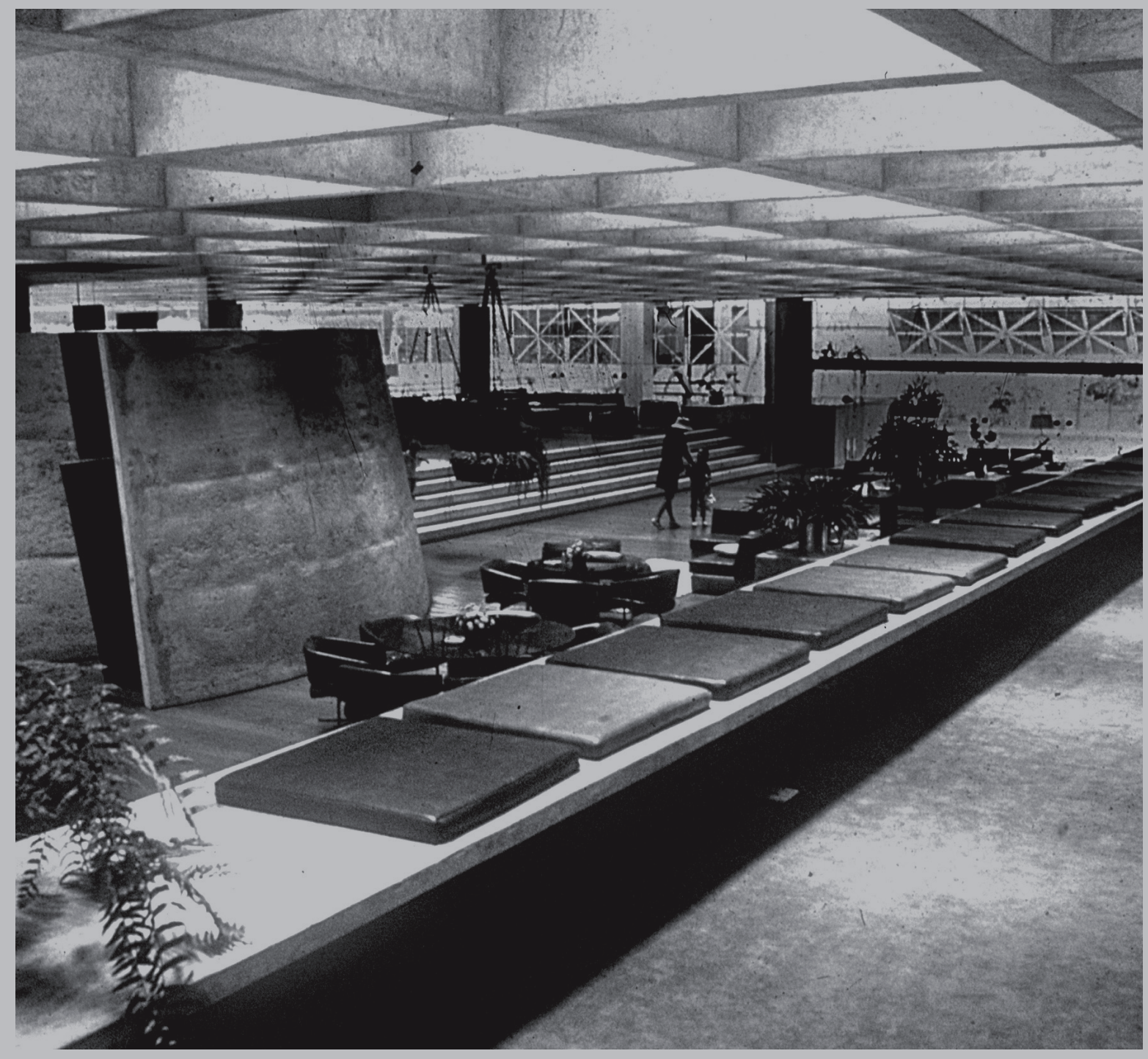




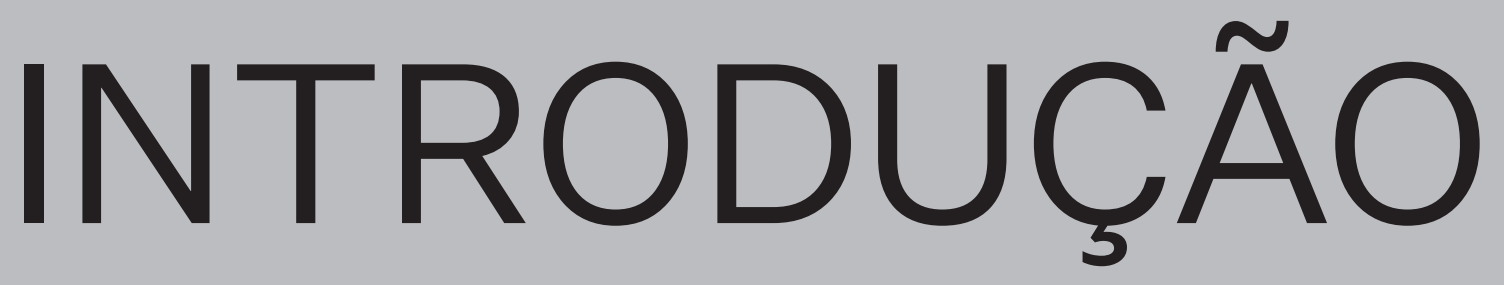


O panorama da arquitetura moderna no Brasil, que se desenvolveu ao longo do século XX, possui ao menos dois grandes conjuntos de obras que se destacaram a partir das vanguardas estabelecidas no Rio de Janeiro, entre os anos de 1930 e 1950, e em São Paulo, nas décadas de 1960 e 1970.

O grupo dos paulistas, que tinha em Vilanova Artigas (1915-1985) o seu principal mentor, era majoritariamente integrado por jovens e talentosos arquitetos formados nos anos 1950 nas faculdades de arquitetura do Mackenzie e da Universidade de São Paulo, entre os quais podemos destacar Carlos Millan, (1927-1964) Fábio Penteado, (1929-2011) Paulo Mendes da Rocha, (1928) Pedro Paulo de Melo Saraiva, (1933-2016), formados no Mackenzie e Jon Maitrejean, (1929) Joaquim Guedes, (1932-2008) e Abrahão Sanovicz, (1933-1999) formados na FAU-USP.

Estes profissionais desenvolveram muitas obras para a iniciativa privada, como casas e clubes, utilizadas como laboratórios para aplicação de técnicas e estratégias de projeto inovadoras que caracterizaram esta vanguarda.

Embora pouco difundido na literatura especializada, o edifício-sede do Clube Harmonia, 1964-1970, dos arquitetos Fábio Moura Penteado, Alfredo Paesani, (1931-2010) e Teru Tamaki, (1934-2013) se enquadra como uma das obras mais representativas deste grupo. Projetado sob os paradigmas que uniam esta vanguarda e com a mais alta tecnologia do concreto armado disponível na época, o edifício tem uma qualidade construtiva exemplar e se encontra em bom estado de conservação e originalidade incentivado pelo tombamento do CONDEPHAAT, no ano de 1992.

O objetivo deste trabalho é reunir, organizar e sistematizar a documentação relativa aos projetos arquitetônicos, execução de obra e tombamento do edifício-sede, contribuindo para a sua divulgação e a análise da obra, fornecendo subsídios para atividades acadêmicas e o ensino de projetos de arquitetura relacionados ao tema.

No primeiro capítulo esta pesquisa se dedica ao levantamento histórico das políticas nacionais e locais que apoiaram o desenvolvimento da Escola Carioca e consequente projeção mundial, a partir da exposição realizada pelo Museu de Arte Moderna de Nova Iorque (MOMA), Brazil builds: architecture new and old,
1652-1942, até a construção de Brasília, a sua obra mais representativa. Na segunda parte do primeiro capítulo é analisado o panorama das obras modernas em São Paulo, a partir das primeiras experiências de Gregori Ilych Warchavchik (1896-1972), até as obras que antecederam o projeto do edifício-sede do Clube Harmonia, em 1964.

O segundo capítulo aponta os antecedentes que promoveram a idealização e construção do edifício-sede desde o surgimento do bairro Jardim América, em São Paulo, da Sociedade Harmonia de Tênis e das trajetórias profissionais dos arquitetos responsáveis pelo projeto analisando suas obras mais representativas até aquele momento.

No terceiro capítulo são organizados e analisados os documentos e desenhos relativos aos projetos do edifício-sede. Esta parte da pesquisa inicia-se com o Concurso de Anteprojeto para a Sociedade Harmonia de Tênis, de 1958, e posteriormente o Concurso para a Nova Sede da Sociedade Harmonia de Tênis, de 1964, desde a concepção até os projetos executivos que viabilizaram a construção do edifício. A obra é analisada com o objetivo de se encontrar similaridades e afastamentos entre outros edifícios modernos produzidos até aquele momento. Além dos apontamentos técnicos, é explorada a relação que o edifício estabelece com a paisagem, a sua concepção como uma praça coberta, a cobertura única e os planos de lajes de piso, o redesenho da topografia e a peça fundamental na articulação dos programas de serviço e social absorvida pela estrutura tronco de cone, nominada forma de exceção.

A tentativa de encontrar pontos de convergência entre as obras analisadas não busca estabelecer um jogo de espelhos entre elas, mas explorar, a partir dos seus antecedentes e produção contemporânea daquele momento, o contexto no qual o edifício-sede foi produzido. 

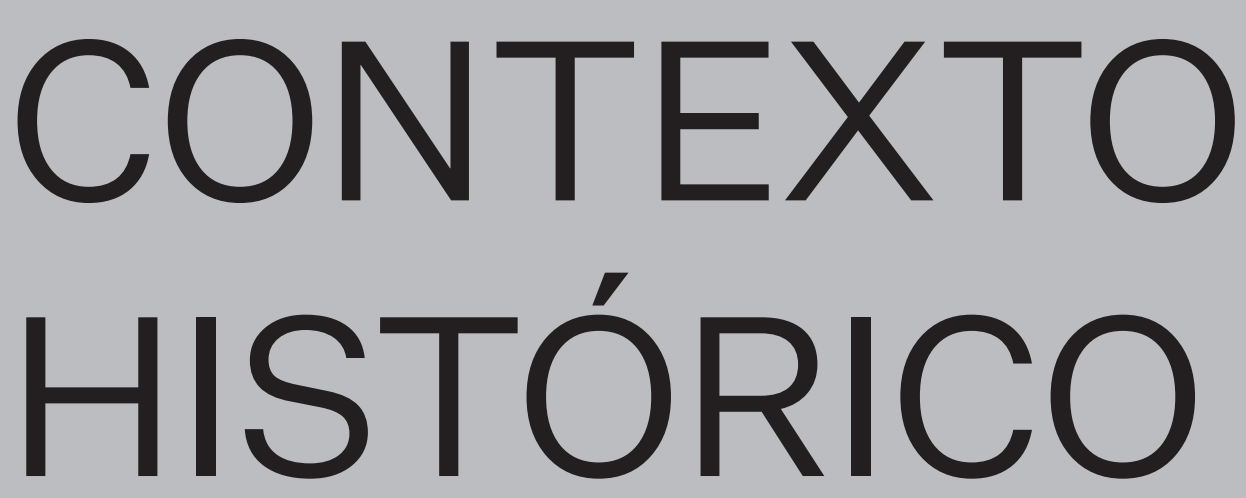


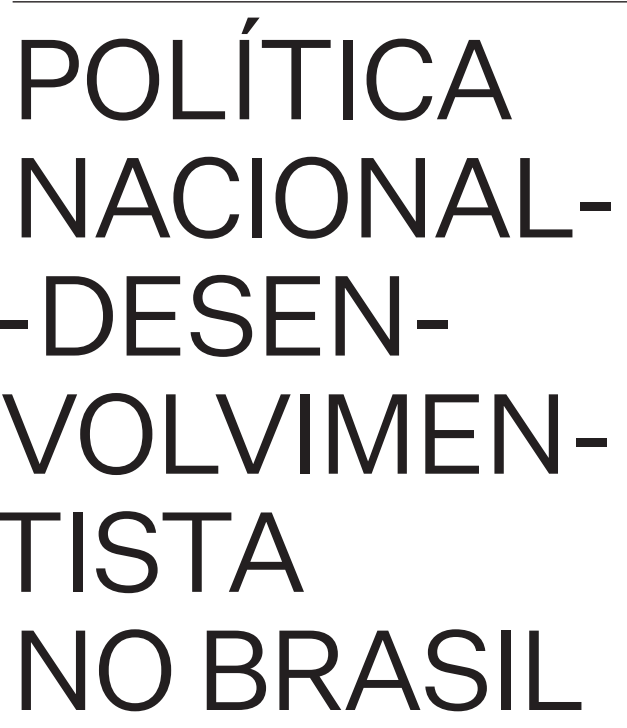

Entre os anos de 1956 e 1964 o Brasil vivenciou um período de profunda transformação política, econômica e social, que teve impacto direto na produção das vanguardas arquitetônicas do país. O impulso nacional-desenvolvimentista promovido pelo governo federal e compartilhado pelos governos estaduais possibilitou a construção de uma série de obras paradigmáticas do movimento moderno brasileiro.

O programa político inicial e mais marcante deste período foi implantado pelo governo nacional de Juscelino Kubitschek, entre 1956 e 1961. O Plano de Metas anunciava "cinquenta anos de progresso em cinco anos de governo" e previa investimentos nos setores públicos e privados que incentivariam a industrialização e modernização do país. Com o propósito de superar o subdesenvolvimento brasileiro através de um modelo econômico autossuficiente, o plano dava continuidade à política de substituição de importações, iniciada após a crise de 1929, com o desenvolvimento do setor manufatureiro brasileiro. Juscelino Kubitschek comprometeu-se com os nacionalistas e trabalhava pela alternância do modelo agrário exportador do país, dominado pelas oligarquias latifundiárias, pelo modelo democrático-burguês. O plano resultou num crescimento econômico acelerado durante o seu governo, às custas de um alto endividamento público e inflação galopante.

A região Sudeste foi a maior beneficiada com o processo de industrialização, recebendo grande parte das novas fábricas, uma vez que possuía melhores condições de infra-estrutura. As novas oportunidades de emprego estimularam a imigração para os principais centros urbanos, consolidando as áreas mais urbanizadas. Em meados de 1960, a maioria da população brasileira já se estabelecia em territórios urbanos (IBGE, 2019). Durante as décadas de 1960 e 1970, a cidade do Rio de Janeiro recebeu em média 100 mil novos moradores a cada ano (IBGE, 2019) ${ }^{1}$ e São Paulo recebeu anualmente quase 200 mil moradores no mesmo período (IBGE, 2019). Havia uma esperança na modernidade das cidades, que transformaria a vida das pessoas e cabia aos arquitetos planejar e projetar este novo Brasil.

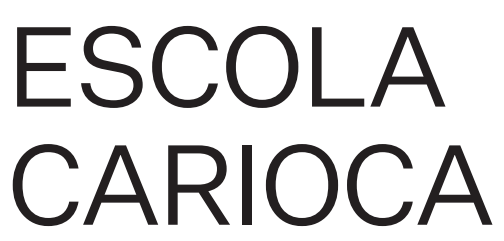

O primeiro curso de arquitetura do Brasil, a Escola Real de Ciências, Artes e Ofícios, foi concebido no Rio de Janeiro em 1816. A partir do decreto de Dom João VI, foram concedidas pensões a diversos artistas franceses que se estabeleceram no Brasil. A chamada missão artística francesa, liderada por Joachim Lebreton (17601819), introduziu no país o projeto academicista para o ensino das artes. O curso de arquitetura ficou sob orientação do professor Auguste Henri Victor Grandjean de Montigny (1776-1850).

A Missão promoveu o neoclassicismo, que se caracterizava pela ênfase no racionalismo, equilíbrio, ordem, moderação e economia, que contrastava com a tradição barroca introduzida a partir do século XVII pelos missionários católicos. O estilo indicava o progresso da colônia, que logo proclamaria a sua independência em relação a Portugal. Logo nas primeiras décadas do século XIX o neoclassicismo protagonizou as encomendas das elites e o barroco, fortemente associado à dominação portuguesa, passou a sobreviver na cultura popular interiorana.

Durante o século XIX a Escola teve seu nome alterado para Real Academia de Desenho, Pintura, Escultura e Arquitetura Civil e, em seguida, para Academia de Artes (1820). Em 1826 o edifício projetado por Auguste Henri Victor Grandjean de Montigny ficou 


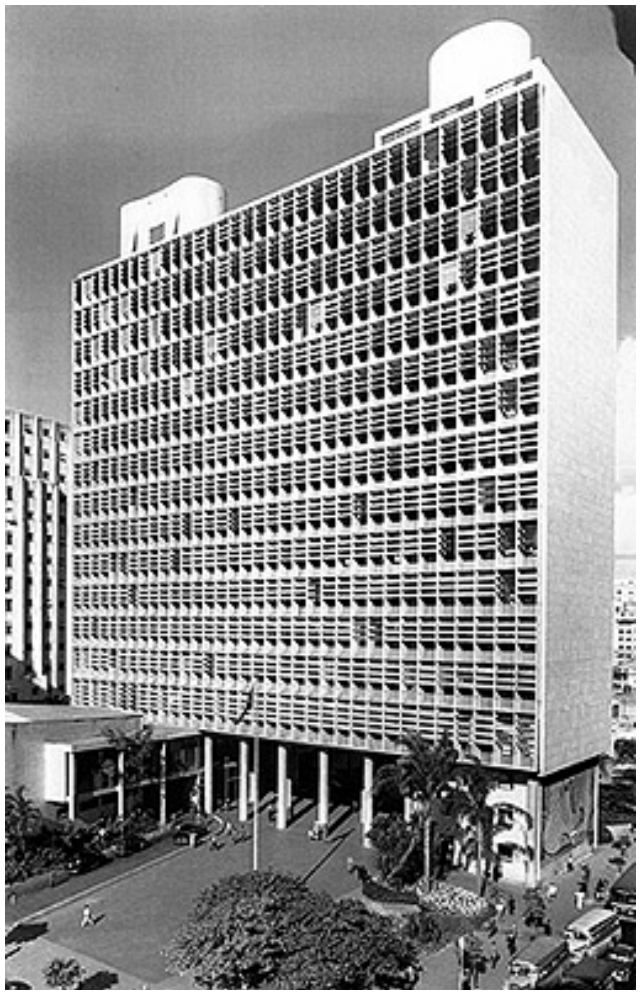

pronto e a escola passou a funcionar plenamente com o nome Academia Imperial de Belas Artes, até o ano de 1890, quando passa a se chamar Escola Nacional de Belas Artes (ENBA). Em 1915, o curso de arquitetura introduziu disciplinas técnicas que ampliaram o conhecimento dos estudantes, que passaram a ser denominados engenheiros-arquitetos.

No final da década de 1920, já havia um grupo de alunos que reivindicava a modernização do ensino na ENBA. Neste período, se formaram na instituição os arquitetos-engenheiros que protagonizaram a vanguarda arquitetônica carioca. Dentre os mais renomados estão Lúcio Costa (1924), Luiz Nunes (1926), Marcelo Roberto (1929), Affonso Reidy (1930), Carlos Leão (1931), Jorge Moreira (1932), Ernâni Mendes de Vasconcelos (1933), Álvaro Vital Brazil (1933), Oscar Niemeyer (1934) e Milton Roberto (1934).

Ao assumir a direção da ENBA, entre dezembro de 1930 e setembro de 1931, Lúcio Costa introduz a renovação no ensino de arquitetura e se torna a principal referência como mentor do grupo de arquitetos modernos cariocas. Atento às novas vanguardas artísticas, o então ministro da Educação, Gustavo Capanema (19001985), convida Lúcio Costa para desenvolver o projeto para o Ministério da Educação e Saúde Pública, (MESP) com o desejo de propagar o progresso e a participar da modernização do país.

Costa reúne uma equipe de recém-formados na ENBA: Affonso Reidy, Carlos Leão, Jorge Moreira, Ernani Vasconcellos, Oscar Niemeyer e contrata a consultoria do arquiteto franco-suíço Le Corbusier.

O edifício do MESP, projetado e construído entre 1936 e 1945, durante o governo de Getúlio Vargas, possui 16 pisos sobre o térreo e tornou-se o primeiro arranha-céu na história a incorporar os cinco elementos que definem o programa moderno corbusiano formulado em 1926: os pilotis; a planta livre; a fachada livre; as janelas em fita; e o terraço-jardim (les pilotis; le plan libre; la façade libre; la fenêtre en bandeau; et toite-terrace), além de se tornar a primeira realização da curtain wall (fachada envidraçada) devidamente orientada para a face menos exposta ao sol, da primeira aplicação em larga escala de brises de proteção (brise-soleil), criado três anos antes por Corbusier, e de introduzir elementos da cultura nacional como os azulejos de Cândido Portinari e jardins tropicais do paisagista Roberto Burle Marx.

A partir de meados da década de 1930, o grupo de arquitetos modernos passa a receber uma série de encomendas estatais e privadas, construindo um conjunto de obras modernas corbusianas com características locais, o qual foi considerado mais tarde por Banham (WISNIK, 2004, p. 25) "o primeiro estilo nacional da arquitetura moderna" e segundo Mindlin ${ }^{3}$ (1975, p.172 apud SEGAWA, 2010, p. 105) a "emancipação e adaptação profunda à terra e ao meio", além de "a mais importante contribuição do Brasil ao patrimônio da cultura universal".

No ano de 1943 o Museu de Arte Moderna de Nova Iorque (MOMA) realizou uma exposição dedicada à arquitetura brasileira "Brazil builds: architecture new and old, 1652-1942”, com destaque para a produção moderna carioca através de obras exemplares, como a Sede da Associação Brasileira de Imprensa (ABI) (1936), dos irmãos Roberto: Marcelo (1908-1964), Milton (1914-1953) e Maurício (1921-1996); a Estação de Passageiros de Hidroaviões (1937), de Attílio Corrêa Lima (1901-1943); o

\section{$1 \uparrow \quad$ Edifício do MESP, 1950}

Fonte: MINISTÉRIO da Educação e Saúde Pública (Rio de Janeiro, RJ). In: ENCICLOPÉDIA Itaú Cultural de Arte e Cultura Brasileiras. São Paulo: Itaú Cultural, 2019. 


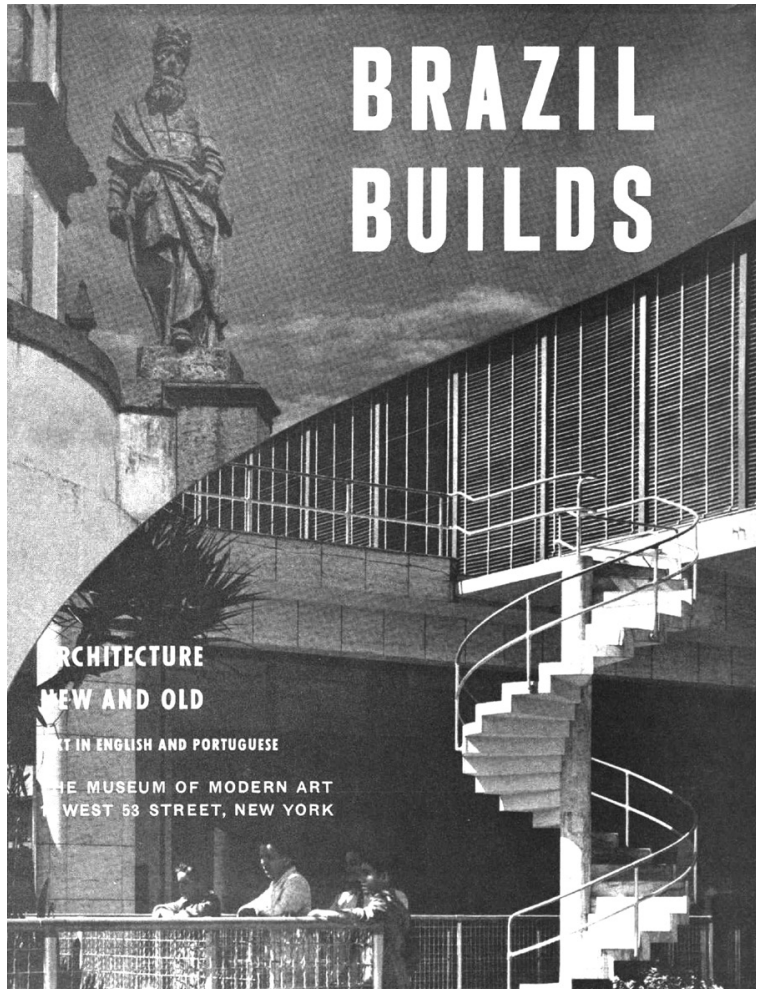

Grande Hotel de Ouro Preto (1938), de Oscar Niemeyer; o Pavilhão do Brasil na Feira Internacional de Nova York (1938-1939), de Lúcio Costa e Niemeyer; e parte do Conjunto Arquitetônico da Pampulha (1942-1944), projetado por Niemeyer em Belo Horizonte a partir da encomenda do então prefeito Juscelino Kubitscheck, além do edifício do Ministério da Educação e Saúde Pública (MESP).

Por meio do catálogo desta exposição, organizado por uma das mais importantes instituições de arte moderna do mundo, a arquitetura brasileira é apresentada em escala internacional. Em texto escrito no ano de 1944 sobre a importância da exposição Brazil Builds, Mário de Andrade (1893-1945) afirma que "a primeira escola, o que se pode chamar legitimamente de 'escola' de arquitetura moderna no Brasil, foi a do Rio, com Lúcio Costa à frente, e ainda inigualada até hoje". Nomeada internamente como "Escola Carioca" e internacionalmente como brazilian style, esta arquitetura passa a figurar equivocadamente como a totalidade da produção nacional.
O primeiro autor a incluir as obras da Escola Carioca foi Bruno Zevi, em 1950, em Storia dell'architettura moderna, ampliadas na edição de 1973 com a inclusão de Brasília. A partir de então tornou-se referência obrigatória nos principais autores que analisam a arquitetura do século 20: Giedion, Dorfles, Hitchcock, Peter, Joedicke, Benévolo, Kultermann, Tafuri e Dal Co, Frampton, Curtis, Montaner, Colquhoun e Cohen, comentada, quase sempre, como uma produção periférica sob a influência de Le Corbusier (...) (CAMARGO, 2019, p. 13)

De acordo com Segawa (2010), com a repercussão internacional a arquitetura brasileira se legitima e passa a ser reconhecida, fato inédito "para uma categoria e para uma prática profissional, até então visível como uma derivação da engenharia ou apenas uma atividade artística associada à construção.” (SEGAWA, 2010, p. 129)

Se Lúcio Costa era o mentor do grupo, o principal arquiteto desta geração, Oscar Niemeyer produziu um conjunto de projetos que suscitou uma geração de admiradores e tornou-se a principal referência para a maioria dos arquitetos brasileiros. Cultivando uma ideologia da social-democracia, ligado à esquerda e ao Partido Comunista Brasileiro, (PCB) propagava fazer da arquitetura instrumento para transformar a vida da sociedade.

A partir da década de 1940, os arquitetos modernos formados na ENBA passam a produzir obras em diversas cidades do Brasil. Em São Paulo, Hélio Duarte (1906-1989) torna-se diretor do Convênio Escolar entre 1948-1955 e reorganiza o sistema educacional, com o apoio do educador Anísio Spínola Teixeira (19001971), a partir do planejamento e execução de 68 equipamentos escolares.

Em 1951, Oscar Niemeyer é convidado para projetar um conjunto de edifícios no Parque do Ibirapuera, em comemoração ao IV Centenário da fundação da cidade de São Paulo. Este projeto, realizado a convite de Ciccillo Matarazzo (1898-1977), foi responsável por introduzir a arquitetura moderna nos edifícios públicos de São Paulo. Com o apoio de uma equipe de arquitetos locais composta por Zenon Lotufo (1911-1986), Eduardo Kneese de Mello (1906-1994), Hélio Uchôa Cavalcanti (1913-1971), Carlos Lemos (1925-) e Gauss Estelita, Niemeyer projeta o conjunto de edificações modernas inaugurado em 21 de agosto de 1954, composto pela grande marquise, Pavilhão da Agricultura, Pavilhão das Indústrias, Pavilhão das Nações, Pavilhão dos Estados e o Pavilhão de Exposição.

$2 \uparrow$ Capa do catálogo "Brazil builds: architecture new and old, 16521942", 1943

Fonte: GOODWIN, 1943, capa. 


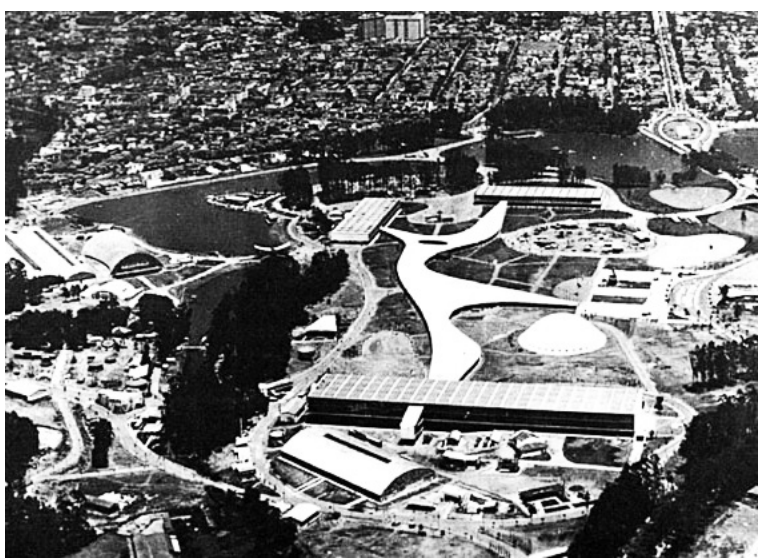

Com a grande repercussão internacional da arquitetura brasileira, diversos estrangeiros, incluindo críticos de arquitetura, vieram para o Brasil. As primeiras críticas contundentes à arquitetura carioca partiram do designer suíço Max Bill (1908-1994), um destacado profissional no cenário internacional, formado pela Escola Bauhaus. Em 1953, em entrevista à revista brasileira Manchete, o suíço se refere ao edifício do MESP afirmando que:

Falta-Ihe sentido e proporção humana; ante aquela massa imensa o pedestre sente-se esmagado. Não concordo, tão pouco, com o partido adotado no projeto, que preferiu condenar o pátio interno construindo o prédio sobre pilotis. O pátio interno seria mais adaptável ao clima, viriam correntes de ar ascendente que produziriam melhor ventilação refrescando o ambiente. (Aquino, p. 38, 1953)
Sobre o conjunto da Pampulha, Max Bill o descreve como: "um barroquismo excessivo que não pertence à arquitetura nem à escultura" e prossegue:

Aliás, a arquitetura moderna brasileira padece um pouco deste amor ao inútil, ao simplesmente decorativo. Ao projetar-se, por exemplo, um conjunto como a Pampulha, não se levou em conta a sua função social. O sentimento da coletividade humana é aí substituído pelo individualismo exagerado. [...]. Niemeyer, apesar do seu evidente talento, projetou-o por instinto, por simples amor à forma pela forma; elaborou-o em torno de curvas caprichosas e gratuitas cujo sentido arquitetural apenas para si mesmo é evidente. 0 resultado disso é um barroquismo excessivo que não pertence à arquitetura nem à escultura.

E conclui: (...) em arquitetura tudo deve ter sua lógica, sua função imediata. Um arquiteto deve ser capaz de defender seu projeto até nos seus menores detalhes. Deve saber responder porque colocou uma porta em tal lugar, porque pintou tal parede de azul, porque empregou determinado tipo de janela. (Aquino, p. 38 e 39, 1953)

Quando perguntado em 1953 sobre os arquitetos brasileiros, Max Bill afirmou "Para mim, o mais importante deles é Affonso Reidy, o autor do projeto do Conjunto do Pedregulho.” (Aquino, p. 39, 1953)

Implantado na costa oeste do morro do Pedregulho, o "Conjunto Residencial Prefeito Mendes de Moraes", teve seu projeto desenvolvido por Reidy, a partir de 1946, para abrigar funcionários públicos da cidade do Rio de Janeiro, então Distrito Federal.

Inaugurado em 1952, o conjunto de edificações inspirado no conceito de "unidade de vizinhança" está inserido num terreno de $52.142,00 \mathrm{~m} 2$. O edifício de maior envergadura possui 260 metros de comprimento e segue o desenho natural da curva de nível, implantado na cota mediana de uma pendente com desnível de $50 \mathrm{~m}$. Além de abrigar 272 unidades habitacionais com vista para a baía de Guanabara, o edifício possui ainda uma creche. O conjunto edificado possui outros dois blocos de habitação com 56 unidades habitacionais, lavanderia coletiva, playground, piscinas com vestiários, quadras esportivas, berçário, escola primária, ginásio, centro de saúde e cooperativa, que se articulam a partir de uma praça.

Outro projeto fundamental desenvolvido por Reidy, o Museu de Arte Moderna do Rio de Janeiro - MAM (1953), lançou as bases do brutalismo arquitetônico no

$3 \uparrow \quad$ Vista aérea do Ibirapuera, 1954

Fonte: Acervo de João Emílio Gerodetti. 


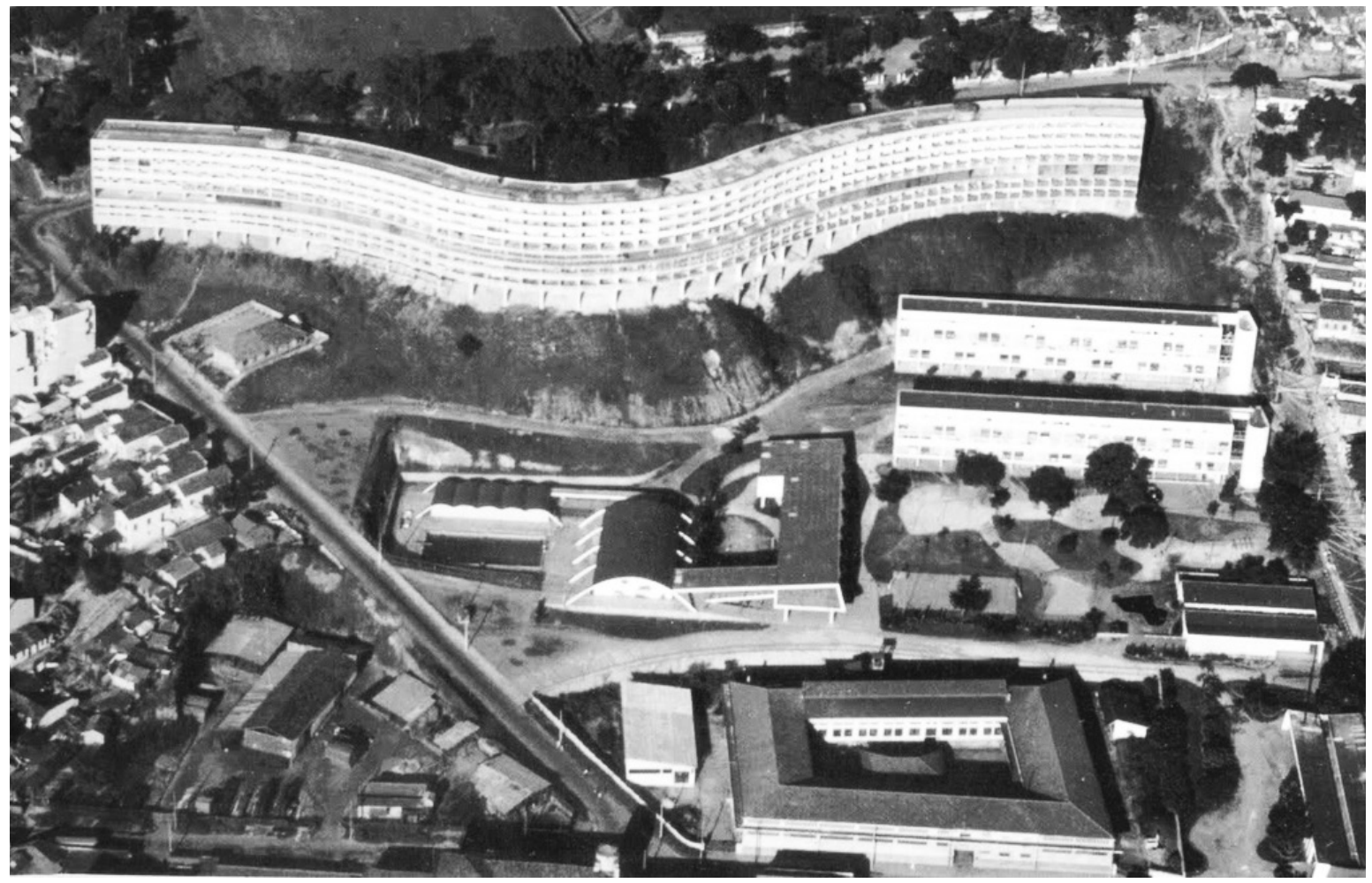

Brasil e se tornou a primeira obra moderna em concreto aparente no país. O projeto vem de forte inspiração na Unidade de Habitação de Marselha, inaugurada um ano antes, em 1952. Projetada por Le Corbusier, de quem Reidy era amigo e se considerava um discípulo, a Unidade de Habitação se tornou a obra seminal do brutalismo no mundo.

O edifício principal do MAM é caracterizado por quatorze pórticos trapezoidais, paralelos, distanciados dez metros entre si. Os pórticos são formado por pilares duplos inclinados em ambos os lados e se unem por meio de vigas que vencem cinquenta metros de vão livre. Em planta, o edifício é um retângulo de $140 \mathrm{~m}$ de extensão por $28,30 \mathrm{~m}$. O pavimento que abriga o pro-

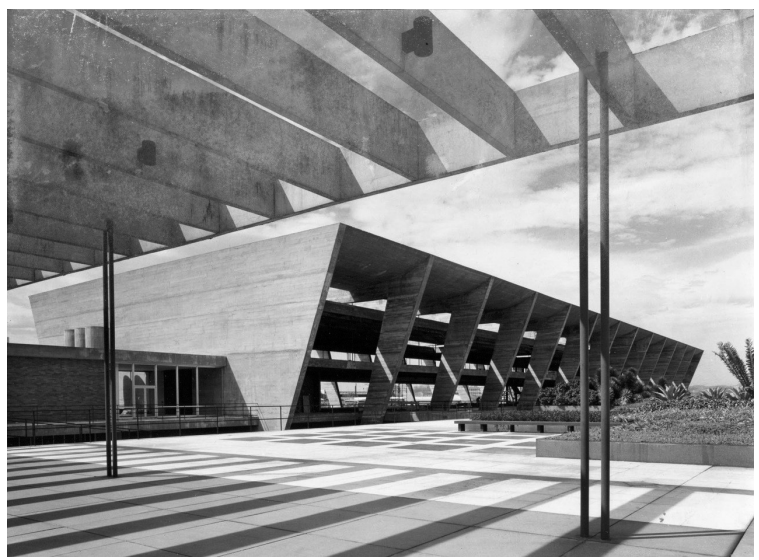
grama do museu está elevado do chão e é apoiado pelos pilares que formam as bases dos pórticos. A cobertura é sustentada pela viga superior, da qual partem os tirantes que estruturam os mezaninos.

Em agosto de 1956, com apenas seis meses da administração de Juscelino Kubitschek, o Congresso

$4 \uparrow \quad$ Vista aérea Pedregulho Fonte: Página Archdaily Brasil. ${ }^{5}$
$5 \uparrow$ Vista Museu de Arte Moderna, Rio de Janeiro, Fonte: Página Archdaily Brasil. ${ }^{6}$ 


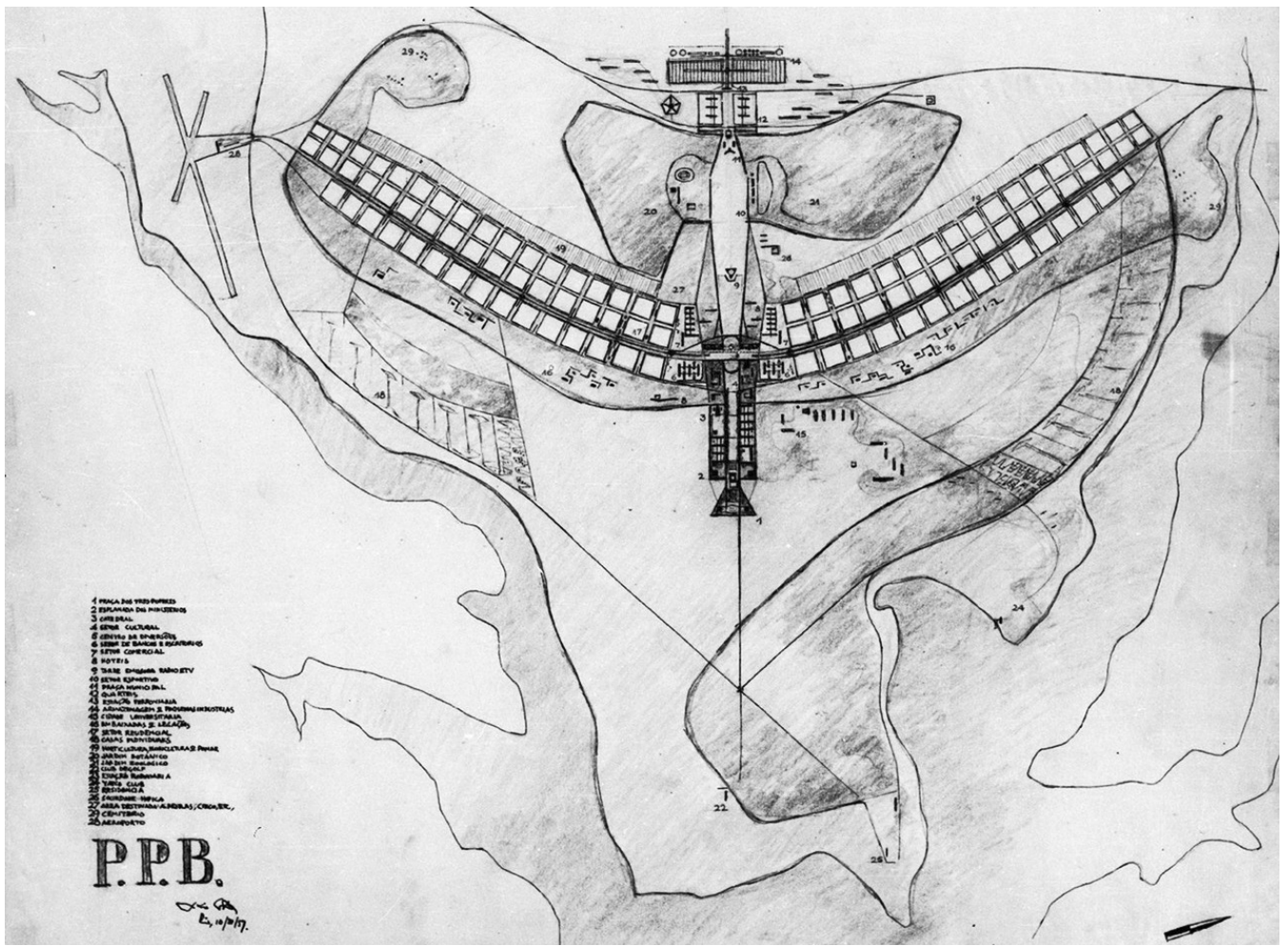

Nacional aprovava a transferência da capital federal para o Planalto Central. Em setembro do mesmo ano, foi divulgado o concurso público nacional para o desenvolvimento do plano urbanístico da nova capital, com previsão para abrigar no máximo 500 mil habitantes. Segawa, (2010) considera que "Nesse momento, Juscelino Kubitschek já havia determinado que Oscar Niemeyer fosse autor dos projetos arquitetônicos dos principais edifícios públicos.” (SEGAWA, 2010, p. 123)

O júri do concurso, formado por três estrangeiros e quatro brasileiros, entre eles Oscar Niemeyer, analisaram vinte e seis projetos dos principais escritórios do país. Em setembro de 1957, o projeto de Lúcio Costa foi proclamado vencedor.

O plano de Lúcio Costa para Brasília é setorizado em quatro escalas: a monumental, implantada no eixo leste/oeste, com os principais edifícios da administração governamental projetados por Niemeyer; a residencial no eixo norte/sul, que contém as unidades de vizinhanças formadas pelas superquadras; a gregária, localizada no cruzamento dos eixos, onde estão a rodoviária projetada por Lúcio Costa, os setores bancários, comerciais e de diversão; e a bucólica, que permeia a cidade e orla do lago Paranoá.

A construção de Brasília pôs em solo nacional uma série de teorias da arquitetura e do urbanismo europeu e tornou-se um dos grande laboratórios da arquitetura moderna mundial. A nova capital, projetada por Niemeyer e Lúcio Costa, é a obra que melhor representa a industrialização e modernização do país daquele período. Embora não fizesse parte do Plano de Metas, a sua inauguração em 1960 tornou-se o maior símbolo da era JK.

O concurso para a nova capital colocou a arquitetura em destaque na imprensa diária e as referências internacionais de revisão do movimento moderno, culminando com a realização do Congresso Internacional dos Críticos de Arte em Brasília, em 1959, fomentaram a criação de um ambiente propício à investigação das artes e da arquitetura, com visíveis desdobramentos na mentalidade dominante. (CAMARGO, 2019 p. 5)

$6 \uparrow \quad$ Plano de Brasília, Lúcio Costa, 1957

Fonte: Página Archdaily Brasil. ${ }^{7}$ 


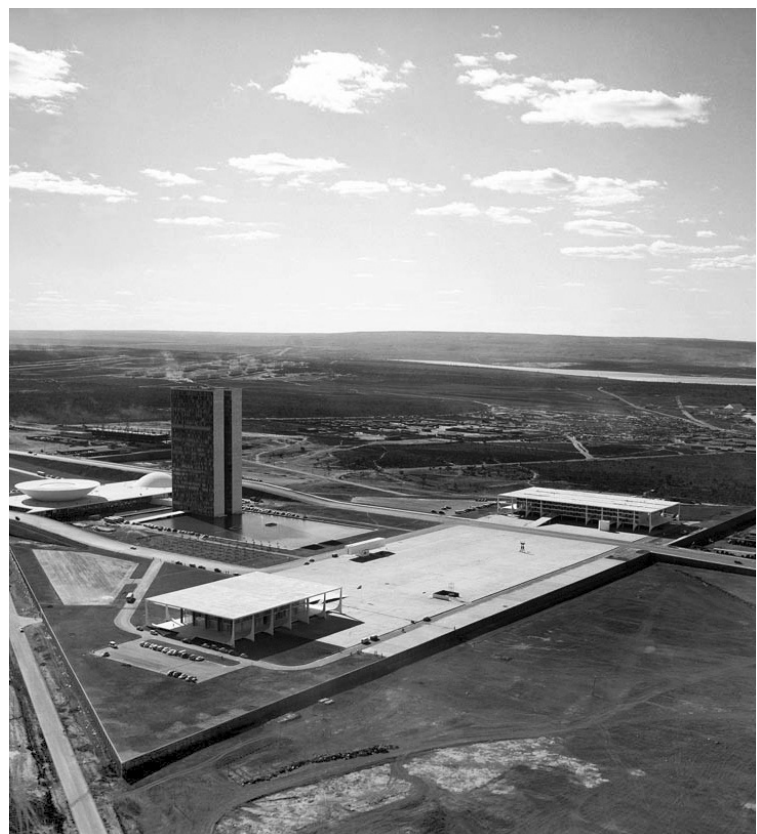

Durante o desenvolvimento do projeto de Brasília, em fevereiro de 1958, Niemeyer publica um depoimento na revista Módulo em tom de autocrítica. Sem citar diretamente Max Bill, escreve que a sua tendência excessiva para a originalidade havia prejudicado a simplicidade, no sentido da lógica e economia de algumas de suas obras. A partir de então, se interessava por soluções compactas, simples, geométricas, atentas aos problemas de hierarquia e na expressão dos edifícios não mais pelos elementos secundários, mas pela própria estrutura, devidamente integrada à solução plástica original bela, inesperada e harmoniosa. Segawa afirma que este manifesto foi "prontamente sentido pelos colegas: seu conteúdo foi seminal para os arquitetos das esquerdas e certamente tornou-se um ponto de partida para uma nova 'linha': um tipo de arquitetura feita em São Paulo, a 'linha paulista'.” (SEGAWA, 2010, p. 144).

Para Segawa, a obra de Brasília está “(...) no bojo desse projeto desenvolvimentista e constitui o marco final dessa vanguarda arquitetônica alimentada por uma política de conciliações ideológicas.” (SEGAWA, 2010, p. 114). Para Wisnik:

Brasília está no centro de qualquer discussão sobre arquitetura brasileira no século XX. Construída em um dos momentos de maior efervescência política e cultural na história do país, Brasília é a expressão máxima de uma arquitetura que está associada, no plano da cultura, a um novo padrão estético no país, que podemos dizer sofisticado sem ser aristocrático. (...) Brasília tornou-se uma baliza para a produção nacional: ela é o ' lugar' para onde converge a produção dos arquitetos cariocas das décadas de 1930, 40 e 50, e de onde parte a produção paulista dos anos 1960 e 70 (...) (ANDREOLI; FORTI, 2004, p. 36-37)

\section{VANGUARDA MODERNA PAULISTA}

Em São Paulo, a primeira geração de arquitetos modernos inicia a sua produção a partir das encomendas privadas. O precursor desse movimento na cidade foi o arquiteto russo, então radicado na cidade, Gregori Ilych Warchavchik (1896-1972). Embora as técnicas construtivas disponíveis e a legislação corrente limitassem o desenvolvimento de uma arquitetura moderna aos moldes europeus, Warchavchik projeta a Casa Modernista da rua Santa Cruz (1927-1928), considerada pelo crítico Yves Bruand (1926-2011), o primeiro exemplar de arquitetura moderna no Brasil. Outra obra marcante da sua produção, a Casa da Rua Itápolis (1929-1930), foi inaugurada com a "Exposição de uma casa modernista", da qual participam alguns dos artistas da Semana de 22 como Anita Malfatti (18891964), Di Cavalcanti (1297-1976), Victor Brecheret (1894-1955), Oswald de Andrade (1890-1954), entre outros, expondo um alinhamento da arquitetura com as demais expressões das artes modernas da época.

O desdobramento desse movimento iniciado por Warchavchik na cidade pode ser observado na obra do

$7 \uparrow \quad$ A Praça dos Três Poderes em Brasília Fonte: Página Archdaily Brasil. ${ }^{8}$ 

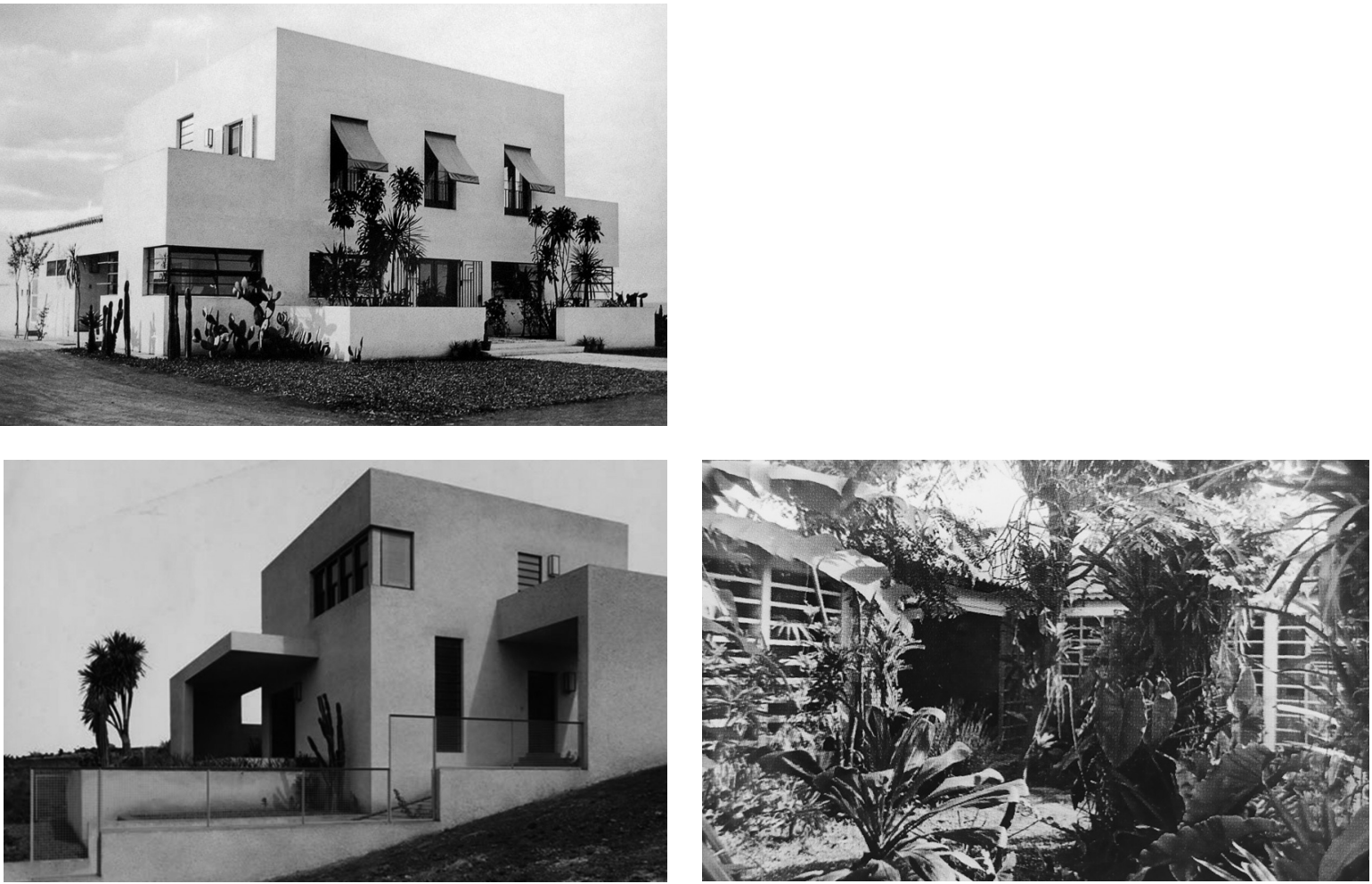

arquiteto Rino Levi (1901-1965) que, impactado pela visita que realizou à Casa da Rua Santa Cruz em 1929, inicia uma produção de obras alinhadas ao pensamento moderno a partir da década de 1930. Rino Levi, formado pela Escola Superior de Arquitetura de Roma em 1926, expressava, além dos aspectos formais da modernidade, preocupações com as técnicas construtivas e ambientais.

A arquitetura inspirada na paisagem, no clima e nas necessidades do cliente era promovida pelo arquiteto norte-americano Frank Lloyd Wright (1867-1959) e foi amplamente difundida pelo mundo, principalmente a partir da Casa da Cascata (1934-1936).

A partir do projeto de sua própria residência, a Casa Rino Levi (1944), o arquiteto inicia a produção de uma série de residências introvertidas, nas quais distribui seus programas em blocos que se unem visualmente através de jardins tropicais, estabelecendo uma relação marcante entre arquitetura e natureza, interior e exterior.

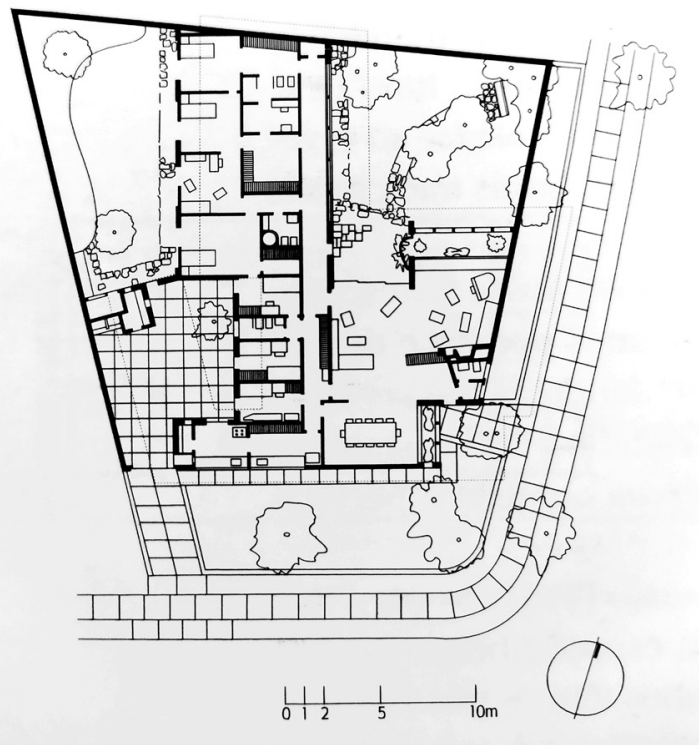

$8 \uparrow$ A Casa Modernista da rua Santa Cruz Fonte: Página Archdaily Brasil. ${ }^{9}$

$9 \uparrow$ A Casa Modernista da rua Itápolis Fonte: Página Archdaily Brasil. ${ }^{10}$
$10 \uparrow$ Casa Rino Levi, jardim principal, 1944 Fonte: (ANELLI; GUERRA; KON, 2001, p. 94).

$11 \uparrow \quad$ Casa Rino Levi, planta Fonte: (ANELLI; GUERRA; KON, 2001, p. 94). 


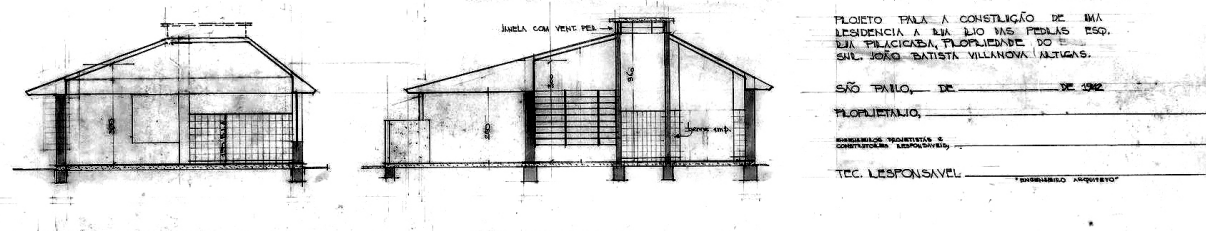

Cant NA Esc 150

COnte BO ESC. 1-80
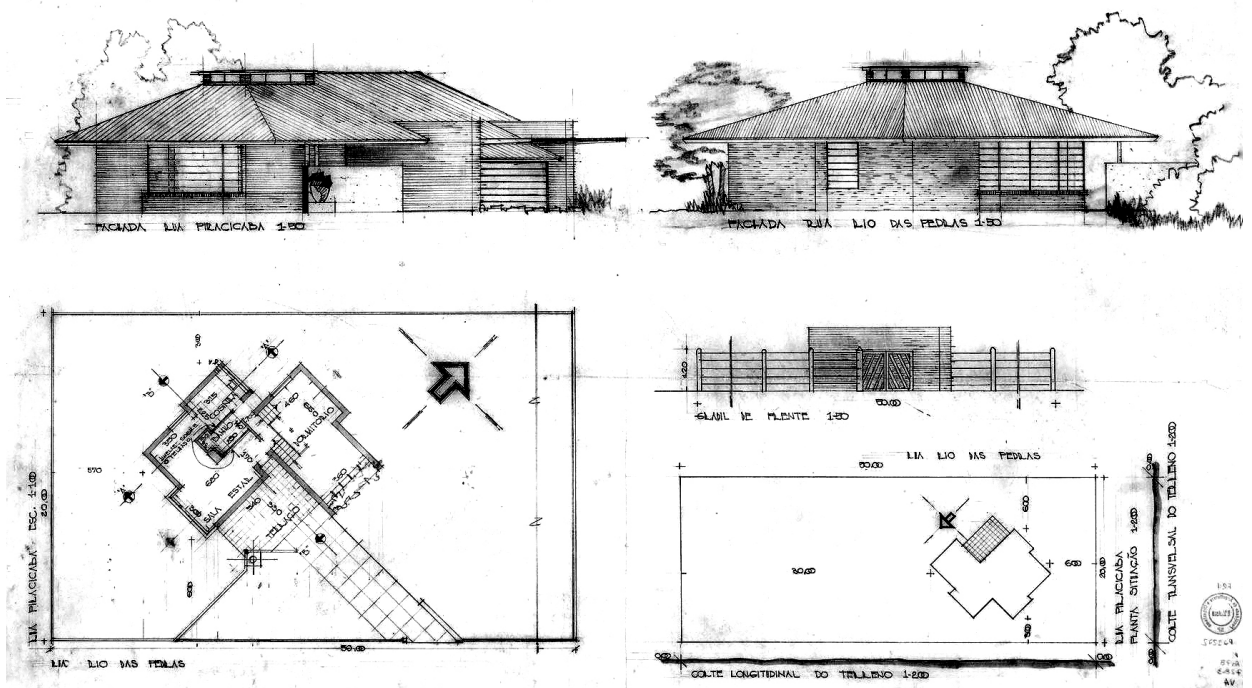

Outro personagem central no desenvolvimento da arquitetura em São Paulo, a partir da década de 1940, foi João Batista Vilanova Artigas (1915-1985). Formado engenheiro-arquiteto em 1937 na Escola Politécnica da Universidade de São Paulo (POLI), Artigas inicia uma pequena construtora com o colega Duílio Marone, com quem projetou cerca de duzentos projetos em estilo eclético, desenvolveu os seus cálculos estruturais e construiu boa parte deles.

Em 1942, orientado pelas formas organicistas de Frank Lloyd Wright, Artigas constrói a própria casa, conhecida como "Casinha" e em 1943 a casa Rio Branco Paranhos, no bairro do Pacaembu. Sua formação ligada à prática construtiva, permite a adaptação dos preceitos wrightiano a partir dos materiais e técnicas locais.

Em 1945, Artigas filiou-se ao Partido Comunista Brasileiro (PCB) e logo se tornou um dos seus membros destacados. $\mathrm{O}$ arquiteto defendia o desenvolvimento de uma arquitetura nacional, como um dos elementos que contribuiriam para a emancipação política e cultural do

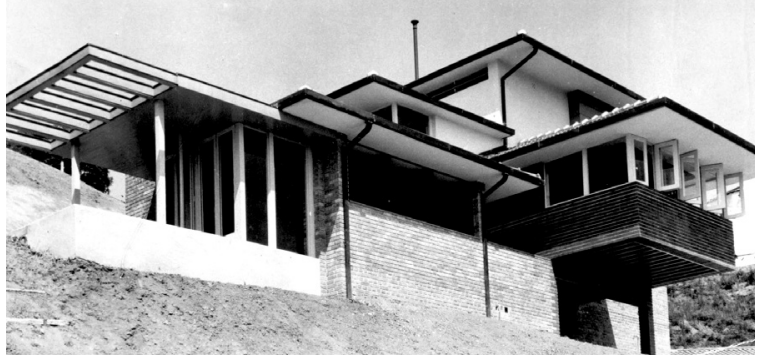

$12 \uparrow \quad$ Casinha, Desenhos Técnicos, 1942 Fonte: Página Vilanova Artigas."

$13 \uparrow$ Casa Rio Branco Paranhos, 1943 Fonte: Página Vilanova Artigas. ${ }^{12}$ 


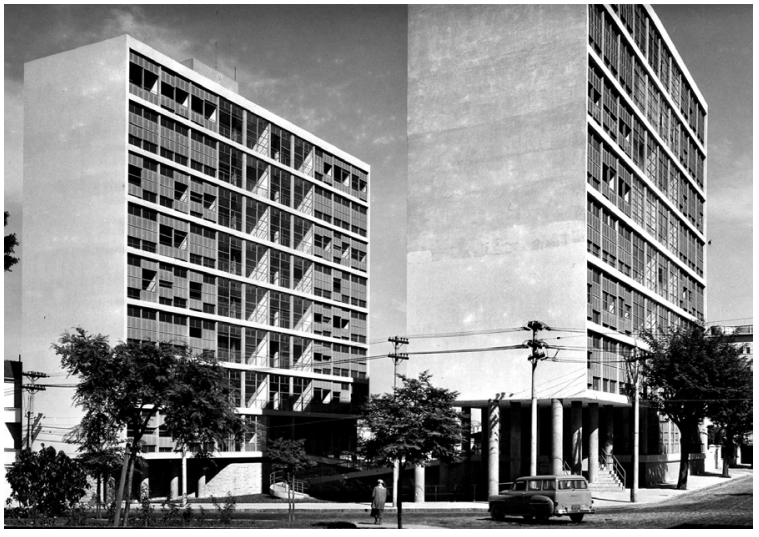

país. Com este propósito, Artigas concebeu um conjunto de obras com clara inspiração na vanguarda carioca, reconhecida como uma adaptação local do modernismo racionalista, coletivista e estandartizável propagado por Le Corbusier. Dentre estas obras pode-se destacar em São Paulo: o edifício Louveira (1946-1950) e a segunda residência de Artigas (1949) e na cidade de Londrina a Casa da Criança (1950), a estação rodoviária (1950) e o edifício Autolon (1953). Boa parte da produção deste período é produzida em parceria com Carlos Cascaldi (1918-1910), ex-aluno de Artigas, que o acompanhou a partir de 1944.

O final da década de 1940 e início da 1950 foi um momento importante para a afirmação da profissão do arquiteto em São Paulo. Os primeiros cursos de arquitetura, antes incorporados aos de engenharia, são emancipados: no Mackenzie em 1947 e na Universidade de São Paulo - USP, em 1948. Pouco tempo depois, em 1951, era inaugurado o Edifício-Sede do Departamento Regional do Instituto de Arquitetos do Brasil (IAB-SP),

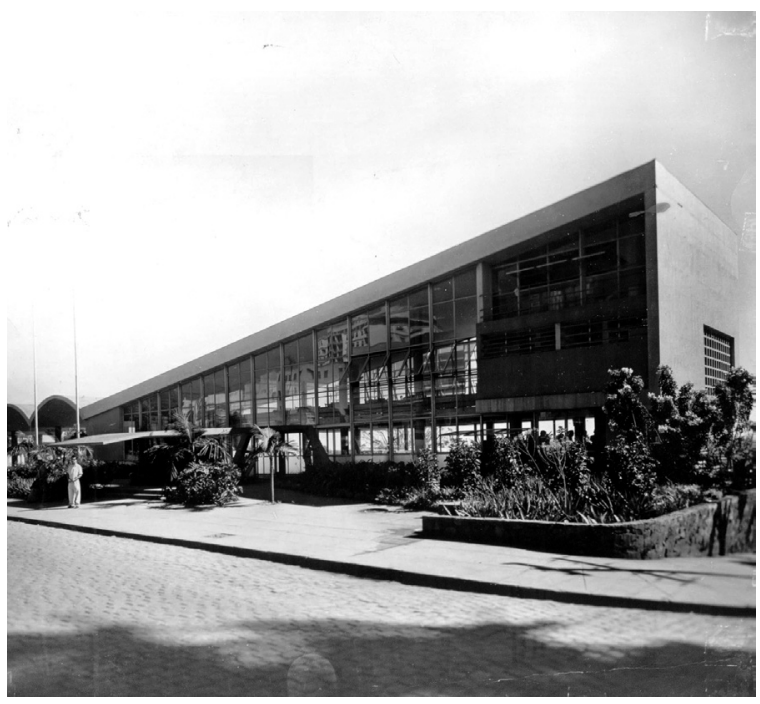

que logo tornou-se local de referência para os encontros e debates sobre arquitetura na cidade.

$\mathrm{O}$ fortalecimento da arquitetura em São Paulo ocorria no mesmo período em que a cidade se estabeleceu como principal polo industrial do país, impondo um processo de expansão e consolidação da metrópole. Ao mesmo tempo, o campo cultural se ampliava com a inauguração do Museu de Arte Moderna de São Paulo (MASP), em 1948, e do Museu de Arte Moderna (MAM), em 1949.

Nesse período, que se sucedeu a Segunda Guerra Mundial (1939-1945), havia um inevitável movimento pela revisão dos conceitos do modernismo. Na arquitetura, Le Corbusier realiza o projeto para a Unidade de Habitação de Marselha (1947-1953), utilizando materiais como o concreto aparente, "béton-brut", marcados pelos processos de construção, valorizando o esforço humano e a história em contraponto aos seus projetos anteriores que se orientavam para o desenvolvimento tecnológico e o futuro. O casal de arquitetos
$14 \uparrow$ Edifício Louveira, 1946 Fonte: Página Vilanova Artigas. ${ }^{13}$
$15 \uparrow$ Rodoviária de Londrina, 1950 Fonte: Página Vilanova Artigas. ${ }^{14}$ 

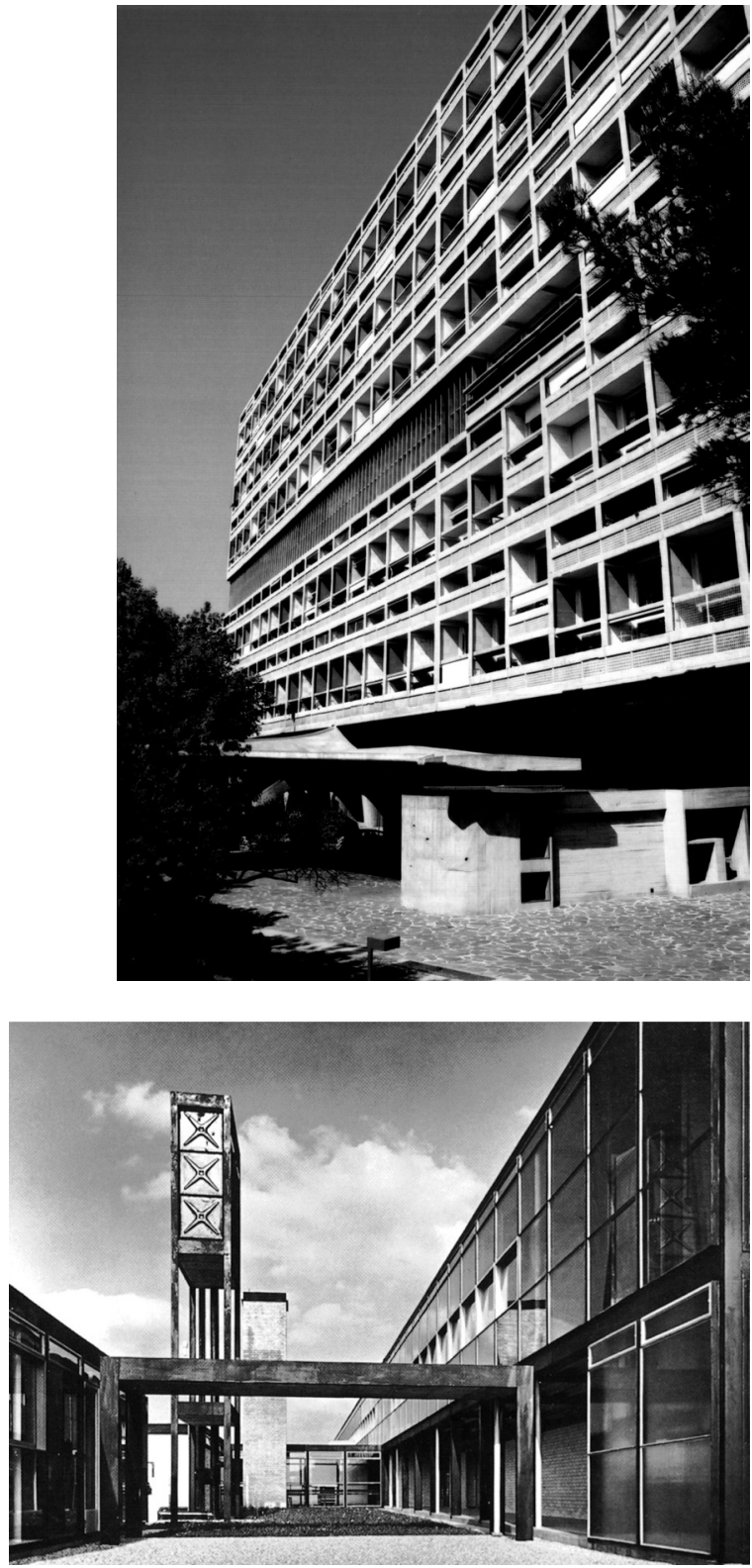

ingleses Alison Smithson (1923-2003) e Peter Smithson (1928-1993) projetaram a escola de Hunstanton (1949-1954) na qual deixaram a estrutura metálica, tijolos de vedação, infraestrutura hidráulica e elétrica expostas, iniciando o movimento do Novo Brutalismo. Suas ideias de revisão do movimento moderno ganharam projeção a partir do X Congresso Internacional de Arquitetura Moderna, realizado em Dubrovnik (1956), antiga Iugoslávia, com a formação do grupo TEAM X.

Em São Paulo, Artigas enfrenta uma crise pessoal que resultou numa estagnação de sua produção arquitetônica, entre os anos de 1952 e 1956. Neste período, inicia uma intensa produção teórica na qual revisava os caminhos da arquitetura moderna no Brasil. Orientado por suas convicções nacionalistas, reformulou as bases do seu pensamento ideológico, produzindo uma crítica frontal ao imperialismo estrangeiro dos quais fariam parte os seus antigos mestres: Le Corbusier e Frank Lloyd Wright. Em 1957, Artigas propõe a reelaboração do ensino da FAU-USP a partir da Disciplina de Projeto como espinha dorsal da matriz curricular.

Até o final da década de 1950, apesar da experiência do Convênio Escolar e do Conjunto do Ibirapuera, respectivamente dirigido e projetado pelos arquitetos cariocas, são pouco expressivas as demandas de projetos públicos modernos por parte do governo e prefeituras de São Paulo. Neste contexto, a elite econômica tornou-se a base de clientes destes arquitetos e, segundo WISNIK, (2015) este setor era também o sujeito de transformação social que repercutia o PCB:

(...) o projeto de reeducação moral da burguesia brasileira veio a se tornar um elemento importante do projeto político do PCB. Pois, na interpretação do partido, o sujeito da transformação social do país não era ainda o proletariado ou o campesinato, mas a burguesia nacional, tida então como progressista. Seria preciso realizar primeiro a revolução democrático-burguesa no país, dizia o partido, e para tanto era vital a reeducação moral dessa classe com vistas à consolidação de ideais mais coletivistas do que privativos, desdobrando-se em costumes mais ascéticos e despojados do que superficiais e decorativos. O projeto da casa burguesa assumia, portanto, contornos revolucionários. (WISNIK, 2015, p. 161-162)

$16 \uparrow \quad$ Unidade de Habitação de Marselha

Fonte: Página capsula.arq. ${ }^{15}$

$17 \uparrow \quad$ Escola de Hunstanton

Fonte: Página capsula.arq. ${ }^{16}$ 


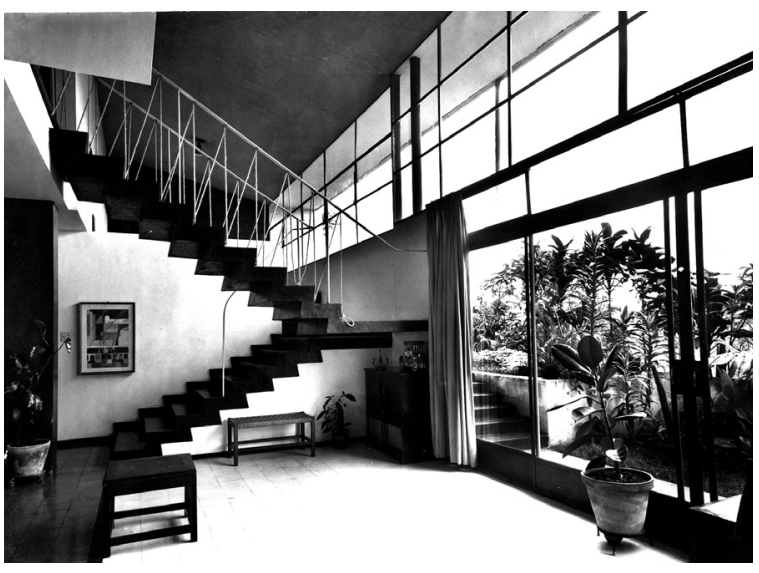

A partir de encomendas para atender a iniciativa privada, Artigas realizou um conjunto de obras residenciais que expressaram as bases projetuais mais radicais da vanguarda que surgiria em São Paulo. Lançando mão das possibilidades tecnológicas que a indústria local propiciava o arquiteto projetou a casa Olga Baeta (19561957), Casa Rubens de Mendonça/Casa Triângulo (1958) e residência Mário Taques Bittencourt (1959).

Para o conjunto de casas projetado no final dos anos 1960, Artigas subverte o modelo do tradicional palacete burguês que possui o programa excessivamente compartimentado e distinção clara na organização funcional do lote em relação à sua frente marcada pela fachada monumental da edificação principal, laterais utilizadas normalmente para a passagem de carro e fundo, onde fica a edificação destinada à guarda do automóvel, áreas de serviços e dormitórios de empregados.

Na casa Olga Baeta (1956-1957), Artigas reúne, sob uma cobertura única, todo o programa que se

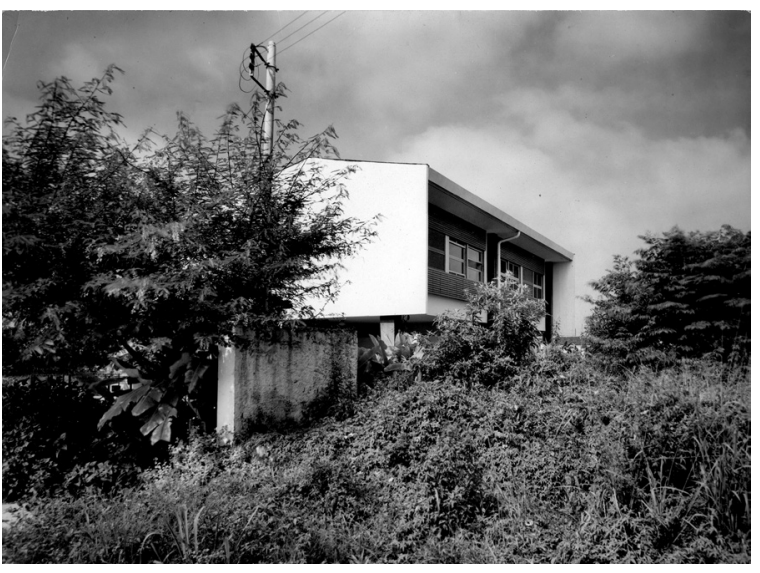

articula de maneira contínua em meios níveis e pés-direitos de alturas variadas. A empena cega voltada para a rua faz com que a casa não possua o caráter hierárquico de frente e fundo. A sala se abre para a face sul por onde se acessa os jardins à frente e ao fundo do lote. A cobertura ocupa o limite dos recuos obrigatórios, e assim, os jardins são incorporados à casa introvertida, que ganha o aspecto de paisagem construída.

Erigidos em uma cidade desprovida de beleza natural evidente e que cresceu muito rapidamente sob a força predatória da especulação imobiliária, esses edifícios deram as costas à trama urbana, procurando reconstruir internamente espaços de uma sociabilidade nova, coletivista e mais austera. (WISNIK, 2015, p. 154)

Na residência Mário Taques Bittencourt (1959) Artigas faz um dos seus exercícios mais radicais ao conceber o volume construído a partir da sua estrutura de pilares, vigas e lajes, estabelecendo "uma identidade
$18 \uparrow$ Casa Olga Baeta Fonte: Página Vilanova Artigas. ${ }^{17}$
$19 \uparrow$ Casa Olga Baeta

Fonte: Página Vilanova Artigas. ${ }^{18}$ 

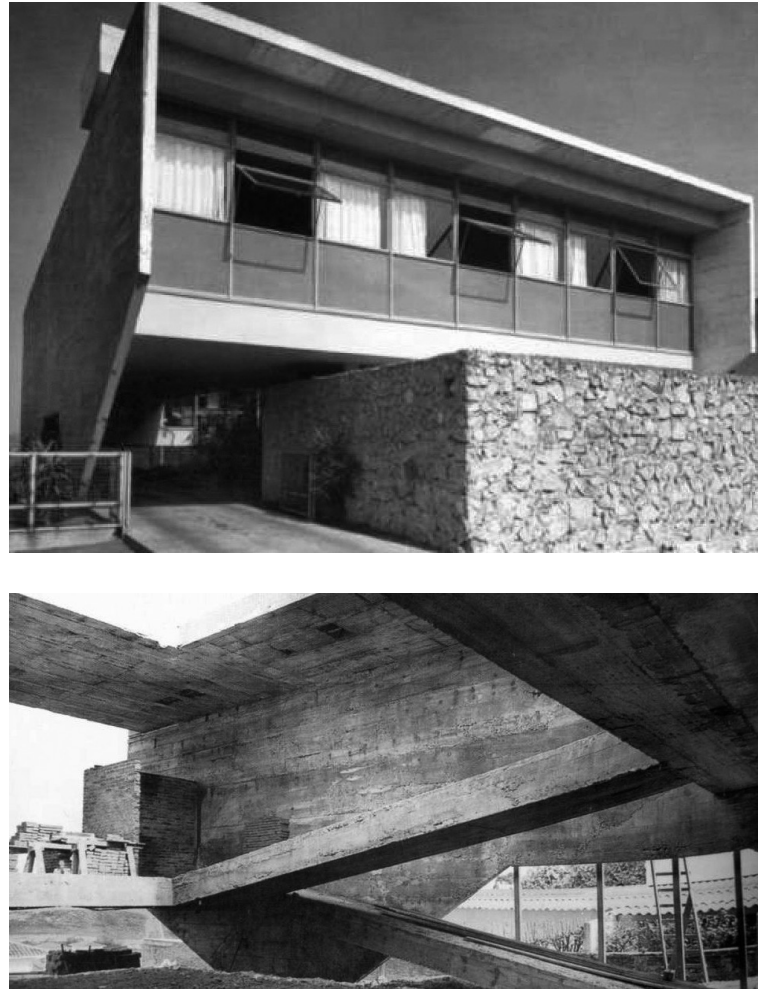

fundamental entre estrutura espacial e estrutura portante" (Wisnik, 2015, p. 163). SEGAWA (2010) considera que este se tornou o carácter mais marcante da arquitetura paulista - a estrutura como arquitetura $\mathrm{e}$ seria tributário da autocrítica de Niemeyer publicada na revista Módulo em fevereiro 1958. A cobertura única se desdobra em duas empenas apoiadas em quatro pilares triangulares. O invólucro, de geometria simples, abriga em seu interior uma espacialidade complexa e radiante. O programa é distribuído em meios-níveis por rampas, em torno de um pátio central luminoso que possui um jardim tropical. A estrutura da casa é construída em concreto aparente, pisos de pedra e madeira natural, além de vedações em aço vidro. Linguagem que se assemelhava ao brutalismo.

Enquanto Le Corbusier utilizou-se da linguagem brutalista para uma revisão do pensamento racionalista e do progressismo técnico, revalorizando as técnicas artesanais, Artigas utilizou-se da linguagem para criar os fundamentos de uma nova arquitetura. Seu objetivo era superar o subdesenvolvimento com base na indústria e nas tecnologias mais avançadas deste período. No momento da efervescência do projeto e obra de Brasília, a esquerda da qual Artigas fazia parte compartilhava da estratégia de desenvolvimentismo brasileiro a partir de convicções nacionalistas e anticolonialistas. Conforme Anatole Kopp, (1990) a arquitetura não seria mais um estilo, mas uma causa.

Havia uma crença coletiva no desenvolvimento do país e em grandes conquistas sociais. O grupo de arquitetos formado por Vilanova Artigas (1915-1985), Ícaro de Castro Mello (1913-1986), Luís Saia (1911-1975), Rino Levi (1901-1965), Eduardo Kneese de Mello (19061994), e Oswaldo Corrêa Gonçalves (1917-2005), cultivava nos mais jovens o interesse pelas teses da arquitetura moderna e na militância política que imaginavam ser capaz de fazer o país encontrar seu próprio e mais justo caminho.

Este discurso atraía para os debates no IAB-SP as turmas de novatos do Mackenzie: Roberto Aflalo (1926-1992), formado em 1950, Carlos Millan (19271964), em 1951, Jorge Wilheim (1928-2014), em 1952, Telésforo Cristófani (1929-2002), em 1952, Fábio Penteado (1929-2011), em 1953, Paulo Mendes da Rocha (1928), em 1954, Pedro Paulo de Melo Saraiva (1933-2016), em 1955 e Francisco Petracco (1935), em 1958 e os alunos recém-formados da FAU-USP: João Clodomiro de Abreu (1927-2010), em 1952, Jon Maitrejean (1929), formado em 1954, Joaquim Guedes (1932-2008), em 1954, Abrahão Sanovicz (19331999), em 1958, Julio Katinsky (1932), em 1957, entre outros como David Libeskind (1928-2014), formado pela Escola de Arquitetura da Universidade Federal de Minas Gerais em 1952.

Ainda no final da década de 1950, o governador Carvalho Pinto, alinhado com as estratégias políticas nacional-desenvolvimentista em curso, implantou o Plano de Ação do Governo Estadual (1959-1963) - PAGE, o qual anunciava que a nova década da cidade de São Paulo seria marcada pela transposição do subdesenvolvimento e caberia à sua administração criar condições para contribuir com essa evolução.

Assim como Kubitschek, o governador Carvalho Pinto deu grande distinção à arquitetura em seu plano. A partir de um acordo com o Instituto de Arquitetos do Brasil (IAB-SP), o PAGE contratou neste período cerca

$20 \uparrow$ Residência Mário Taques Bittencourt Fonte: Arquivo FAU/USP.

$21 \uparrow$ Residência Mário Taques Bittencourt Fonte: Arquivo FAU/USP. 

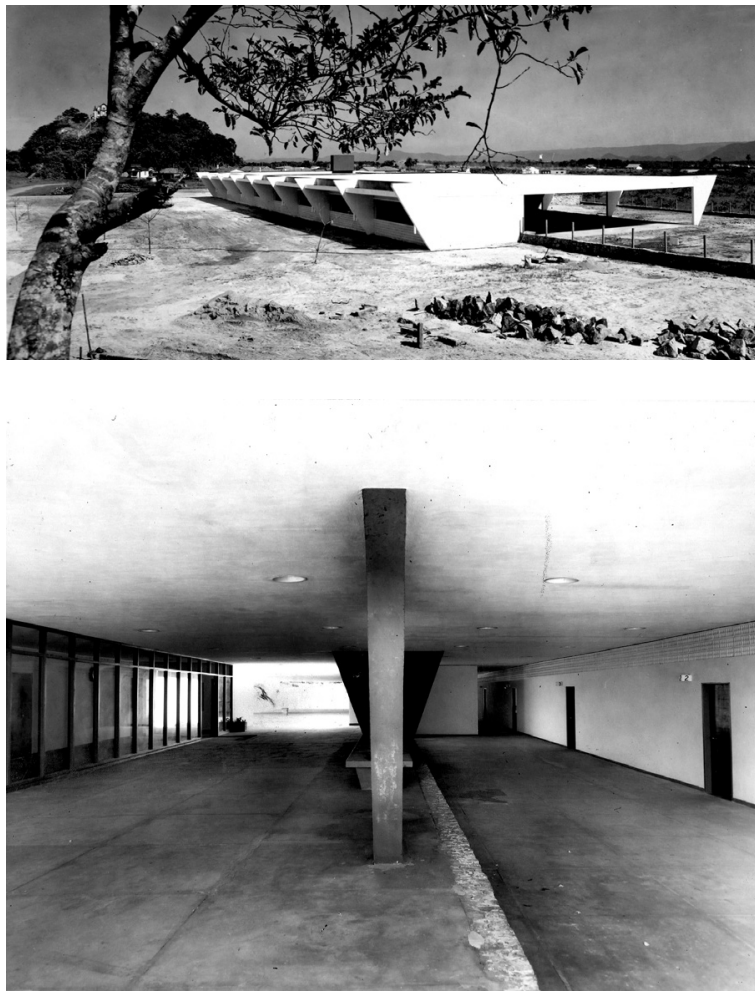

de 160 arquitetos, mais de mil projetos e construiu aproximadamente 400 equipamentos públicos, entre eles fóruns, postos de saúde, escolas (primárias, secundárias, técnicas e profissionais) e a Cidade Universitária Armando Salles de Oliveira (USP-São Paulo), além de criar a FAPESP - (Fundação de Amparo à Pesquisa do Estado de São Paulo), conforme levantamento realizado pela pesquisa de Buzzar e Camargo (2009, p.369).

Dentre os arquitetos contratados estavam Artigas, principal interlocutor entre o IAB-SP e o governo estadual, Eduardo Corona (1921-2001), Carlos Millan, Paulo Mendes da Rocha, Pedro Paulo de Mello Saraiva, Joaquim Guedes, Julio Katinsky, Abrahão Sanovicz, Jon Maitrejean, todos professores da FAU-USP, além de Fábio Penteado e Affonso Reidy, quem despertava imensa admiração dos arquitetos paulistas.

Artigas, em entrevista à revista Acrópole, corrobora essa tese do acúmulo de uma experiência a partir das obras particulares e da possibilidade de colocar sua tese social em prática a partir da contratação do PAGE
(...) Um plano de emergência como se vê. Para a emergência, os órgãos de projeção do Estado não estavam aparelhados. Para ajudá-los, resolveu-se atribuir projetos a arquitetos de fora da estrutura do funcionalismo público. Já tinham uma experiência técnica, acumulada a duras penas, realizando obras particulares. Assim foi projetado, em tempo relativamente curto, um conjunto apreciável de escolas, e a sociedade tomou conhecimento da existência dessa reserva técnica que são os quadros da arquitetura paulista. (...) (Acrópole, 1970 p. 12)

Após utilizar-se das obras privadas para o exercício projetual, Artigas produziu as suas obras mais radicais que simbolizaram a vanguarda paulista daquele momento. Dentre as obras públicas contratadas pelo PAGE, Artigas, em parceria com Carlos Cascaldi, conceberam o Ginásio de Itanhaém (1960/1961), o Ginásio Estadual de Guarulhos (1960), o Ginásio Estadual de Utinga (1961/1968) e o edifício da FAU-USP (1961).

O Ginásio de Itanhaém é o primeiro a desenvolver todo o programa da escola sobre uma única cobertura, eliminando o galpão de esportes/recreio coberto e demais obras anexas. Os três blocos sob a cobertura que circundam o pátio descoberto correspondem às salas de aula, administração e conjunto de sanitários e cantina. As áreas cobertas entre os blocos, utilizadas como circulação, possuem dimensões para serem lugares de encontro e permanência. Uma grande área livre pode ser utilizada como quadra de esportes ou espaço para confraternizações com palco para apresentações. A ambientação destas áreas com múltiplas formas de apropriação se dá pela variação de nível do piso; desta maneira, o pé-direito varia entre $2,50 \mathrm{~m}$ e $3,00 \mathrm{~m}$ proporcionando uma edificação horizontal que evita a monumentalidade das fachadas. A estrutura que define a volumetria do edifício é composta por pórticos trapezoidais que sustentam a cobertura, lembram o MAM de Reidy, e são desdobramentos dos pilares antes experimentados na Casa Rubens de Mendonça.

Ambos os projetos implantaram seus programas sob uma cobertura única apoiada por pórticos estruturais em torno de um pátio iluminante. $\mathrm{O}$ projeto de Itanhaém é térreo e o pátio, descoberto.

O Ginásio de Guarulhos é implantado em três níveis para acomodar o terreno em declive. Utilizando-se de meios-níveis, o programa é distribuído em torno do

$22 \uparrow$ Ginásio de Itanhaém Fonte: Página Vilanova Artigas. ${ }^{19}$

$23 \uparrow$ Ginásio de Itanhaém

Fonte: Página Vilanova Artigas. ${ }^{20}$ 


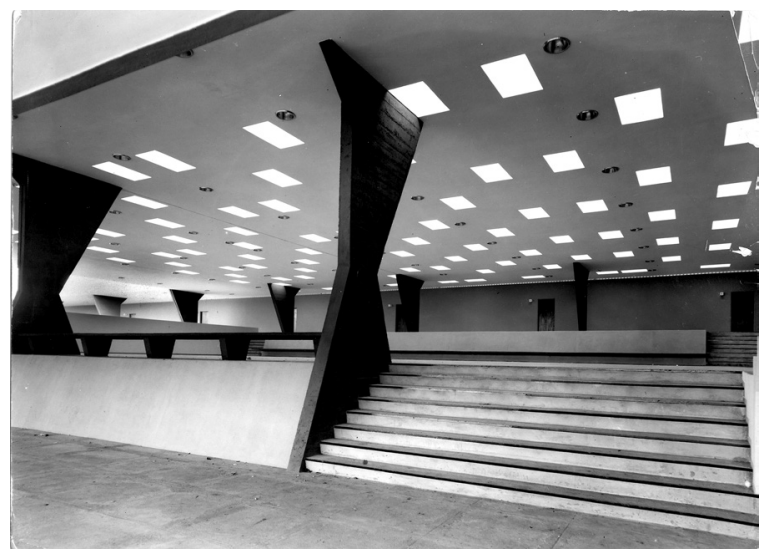

pátio coberto iluminado por domos, localizado no platô intermediário e nomeado praça central. O programa fluído, também sob uma cobertura única, se contrapõe ao modelo de escola vigente, caracterizado pela repartição entre as áreas de estudo e convívio dos estudantes.

Embora o PAGE como um todo não se tratasse de uma produção de obras homogêneas, dentre os projetos desenvolvidos, alguns refletiam a nova arquitetura proposta pelo grupo do IAB-SP, baseada na ética construtiva, e tensão estrutural como expressão, exemplo maior é o edifício da Faculdade de Arquitetura e Urbanismo da Universidade de São Paulo - FAU-USP, de Vilanova Artigas, projetada em 1961.

A partir do módulo básico de $1,10 \mathrm{~m}$ e suas variações $(0,275 \mathrm{~m}, 0,55 \mathrm{~m}, 1,1 \mathrm{~m} \mathrm{1,65m}$, etc.) Artigas projetou uma grande cobertura de $66 \mathrm{~m} \times 110 \mathrm{~m}$, inteiramente iluminada por domos que se dobra em uma fachada cortina, apoiada em 14 pilares periféricos e 18 pilares internos. $\mathrm{O}$ aspecto horizontal do invólucro, abriga o programa da faculdade em oito pavimentos distribuídos por meio de rampas em torno da praça central.

Embora a cobertura estivesse prevista para ser executada em concreto protendido e elementos pré-fabricados, em consonância com o desenvolvimento e industrialização da tecnologia nacional, o alto custo de execução inicialmente postergou, a obra que foi concluída apenas em 1968, a partir do sistema convencional de concreto armado moldado in loco.

O edifício não possui fechamentos no nível do térreo, seu acesso é franco e sugere uma continuidade da área pública externa por meio de um percurso em rampas de dimensões amplas que se tornam lugares de encontros. A materialidade despojada do concreto aparente e fachada horizontalizada que evita a monumentalidade, contém uma qualidade espacial interna de grande impacto. Ao valorizar os espaços de convivência e evitar o impedimento ao seu livre acesso, a FAU-USP tornou-se símbolo maior da vanguarda paulista, concebida como suporte para o uso coletivo e indiscriminado, inspirando uma sociedade mais justa.

$24 \uparrow$ Ginásio de Guarulhos Fonte: Página Vilanova Artigas. ${ }^{21}$

$25 \uparrow$ Ginásio de Guarulhos

Fonte: Página Vilanova Artigas. ${ }^{22}$ 
Pensei que este espaço fosse a expressão da democracia. Pensei que o homem na Faculdade de Arquitetura teria o viço e que nenhuma atividade seria ilícita, que não teria de ser controlada por ninguém, e que os espaços teriam uma dignidade de tal ordem que eu não podia pôr uma porta de entrada, porque era para mim um crime. (ARTIGAS, 2004, p.194)

O PAGE consolidou um conjunto de projetos e obras e, nas palavras de Wisnik (2015) "vem dessa circunstância a primeira percepção palpável de uma 'escola paulista': a reunião de um grupo afirmando em uníssono as mesmas ideias com vistas à criação de uma clara política para a área”. Para Camargo (2016):

\begin{abstract}
Se as residências projetadas por Artigas na segunda metade da década de 1950 conformam o tipo arquitetônico que formalmente configurou a Escola Paulista, sua dimensão social, para além da família, só foi propiciada pelo Plano de Ação. Sem ele, não haveria Escola Paulista, tal como a conhecemos, não haveria o edifício escolar como o tipo de equipamento que em grande parte redimiu a arquitetura moderna em São Paulo do distanciamento social de que era acusada a arquitetura moderna brasileira em geral. (CAMARGO, 2016 p.170 e 171)
\end{abstract}

Embora não exista unanimidade no uso do termo Escola, a vanguarda arquitetônica moderna de São Paulo é reconhecida por diferentes autores como arquitetura paulista, escola paulista, linha paulista, projeto paulista, brutalismo paulista, escola brutalista paulista, entre outros. Pode-se, no entanto, destacar alguns de seus atributos conforme, por exemplo, sugere Wisnik (2015):

Suas características principais são a adoção de um partido estrutural ousado como definidor da forma, o largo emprego do concreto armado ou protendido, a volumetria compacta encimada por uma cobertura iluminante, a predominância de empenas cegas obstruindo uma relação mais franca entre o interior e o exterior do edifício, e a ênfase na criação de uma espacialidade interna contínua. Espacialidade essa balizada por pátios, jardins ou grandes vazios capazes de tragar atributos 'paisagísticos' dos espaços externos para o interior das construções. (WISNIK, 2015, p. 153)
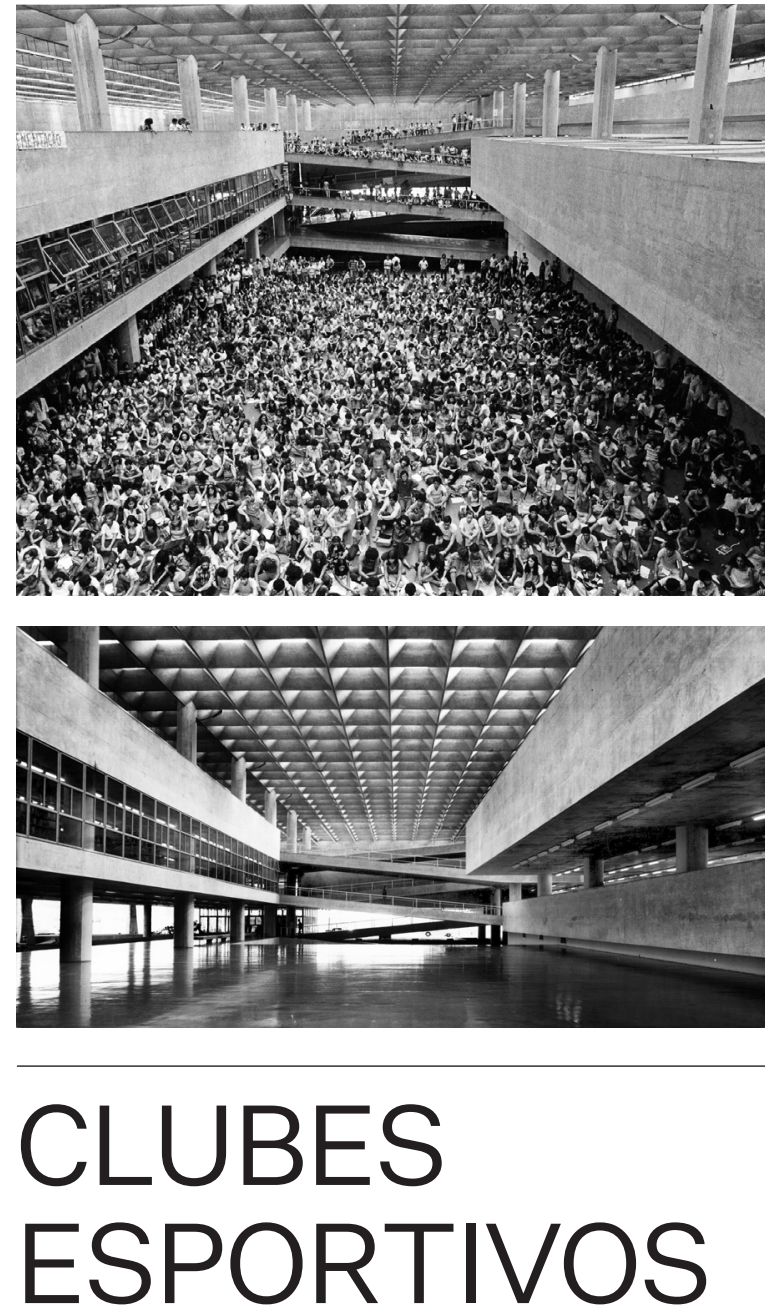

O cenário desenvolvimentista na virada dos anos 1950 e 1960, coroado com a obra de Brasília, seduzia parte da elite econômica paulista, que se tornou, ao lado do governo Carvalho Pinto, o principal contratante de obras modernas de arquitetura em São Paulo. Além das casas burguesas, os clubes esportivos eram tema frequente de publicações especializadas, geralmente contratados a partir de concursos de arquitetura.

Artigas e os demais colegas produziram uma série de obras notáveis para encomendas privadas. Este projetos, assim como o conjunto de casas já citado, 


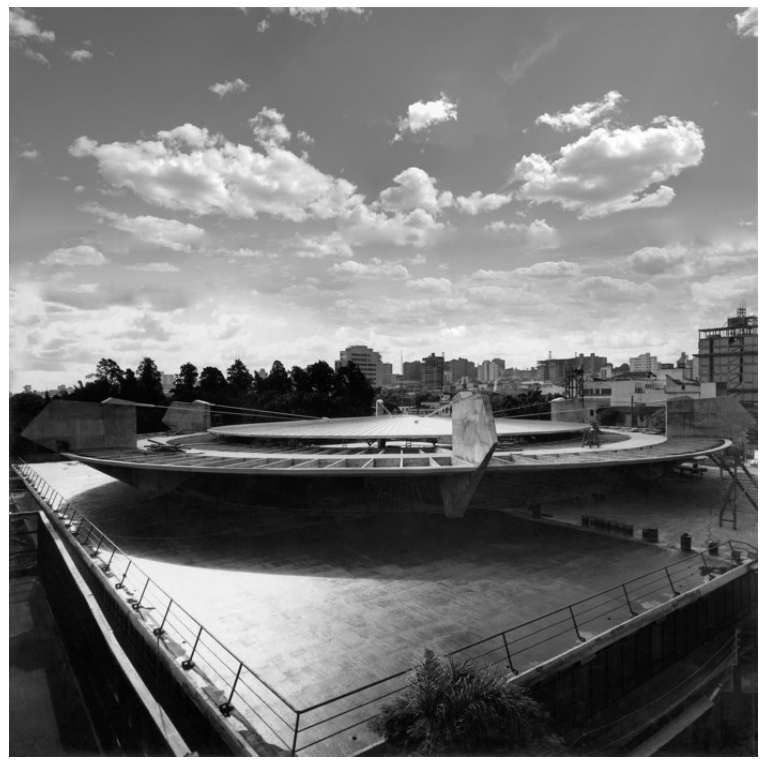

poderiam ser considerados laboratórios para a proposição de novas soluções arquitetônicas.

Exemplo maior deste grupo, Paulo Archias Mendes da Rocha (1928), formado em 1954 pela Universidade Mackenzie, venceu o concurso para o ginásio do Clube Paulistano em 1958, quando tinha apenas 29 anos de idade.

Este edifício, que segundo o próprio arquiteto, inaugura a vida pública de Paulo Mendes, é também um dos precursores desta vanguarda paulista que se aliava à capacidade tecnológica da indústria da construção nacional para produzir uma nova modernidade.

O edifício, inaugurado em 1961, redesenha a topografia natural implantando o programa semi-enterrado com quadra esportiva, duas arquibancadas opostas e programa de apoio, coberto por três estruturas em diferentes níveis: uma plataforma retangular de aproximadamente $75 \mathrm{~m} \times 60 \mathrm{~m}$, a $2,5 \mathrm{~m}$ de altura em relação ao terreno natural, que é também acesso às arquibancadas. A circulação sobre a plataforma é coberta por um anel

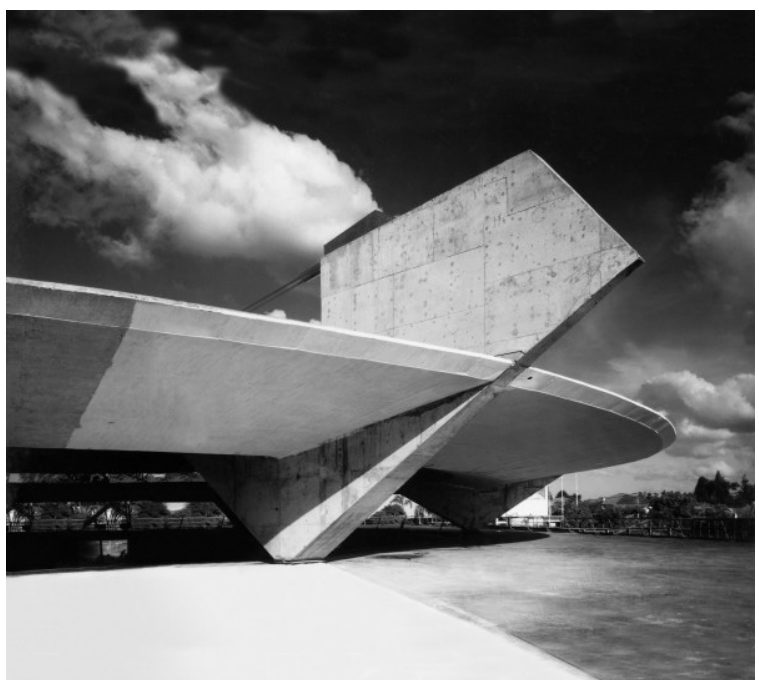

de concreto com aproximadamente $60 \mathrm{~m}$ de diâmetro e $12.50 \mathrm{~m}$ de largura apoiado em seis pilares trapezoidais que se destacam na paisagem. Sobre o anel de concreto uma cobertura metálicas leve com aproximadamente $35 \mathrm{~m}$ de diâmetro, apoia-se no anel em concreto na sua periferia e é atirantada na sua porção central por cabo ancorados nos seis pilares.

Em levantamento realizado por diversos autores: DEDECCA (2012), LIRA (2019), VALDES (2016), SANTOS (2002) pode-se verificar o quão numerosas foram as obras dos clubes esportivos projetados entre os anos de 1956 e 1964 por arquitetos do grupo paulista, dentre os quais:
$28 \uparrow$ Ginásio do Clube Paulistano Fonte: Página Archdaily Brasil. ${ }^{25}$
$29 \uparrow$ Ginásio do Clube Paulistano Fonte: Página Archdaily Brasil. ${ }^{26}$ 
Clubes esportivos projetados

entre os anos de 1956 e 1964

\begin{tabular}{lll} 
ANO & CLUBE & ARQUITETOS \\
\hline 1956 & Botucatu Tênis Clube & Zenon Lotufo \\
\hline 1957 & $\begin{array}{l}\text { Clube Hípico } \\
\text { de Santo Amaro }\end{array}$ & Paulo Mendes da Rocha
\end{tabular}

1957 Associação Esportiva İ́aro de Castro Mello
São José dos Campos

1957 Federação Universitária İ́caro de Castro Mello Paulista de Esportes

\begin{tabular}{|c|c|c|}
\hline 1958 & Araçatuba Clube & Ícaro de Castro Mello \\
\hline 1958 & $\begin{array}{l}{ }^{*} \text { Clube Harmonia } \\
\text { de Tênis }\end{array}$ & $\begin{array}{l}\text { Fábio Penteado, Luiz Forte } \\
\text { Netto e José Maria Gandolfi }\end{array}$ \\
\hline 1958 & $\begin{array}{l}\text { *Ginásio de Esportes } \\
\text { do Clube Atlético } \\
\text { Paulistano }\end{array}$ & $\begin{array}{l}\text { Paulo Mendes da Rocha } \\
\text { e João Eduardo Genaro }\end{array}$ \\
\hline 1958 & $\begin{array}{l}\text { Clube de Campo } \\
\text { São Paulo }\end{array}$ & Ícaro de Castro Mello \\
\hline 1959 & $\begin{array}{l}\text { Associação Atlética } \\
\text { Banco do Brasil }\end{array}$ & Ícaro de Castro Mello \\
\hline \multirow[t]{2}{*}{1960} & Ocian Praia Clube & Ícaro de Castro Mello \\
\hline & $\begin{array}{l}\text { *Edifício Sede do Jockey } \\
\text { Clube de São Paulo }\end{array}$ & $\begin{array}{l}\text { Carlos Millan, Jorge Wilheim } \\
\text { e Maurício Tuck Schneider }\end{array}$ \\
\hline 1961 & $\begin{array}{l}\text { Clube Paineiras } \\
\text { do Morumbi }\end{array}$ & Carlos Millan \\
\hline
\end{tabular}

1961 Anhembi Tênis Clube Vilanova Artigas

1961 Vestiário e piscina Vilanova Artigas do São Paulo

\begin{tabular}{lll} 
ANO & CLUBE & ARQUITETOS \\
\hline 1961 & $\begin{array}{l}\text { Garagem de barcos } \\
\text { do Santa Paula } \\
\text { late Clube }\end{array}$ & Vilanova Artiga
\end{tabular}
1961 *Sede Social Esportiva Ana Mattel, Bernardo do Clube Esportivo Wettreich e Milton Teferman Israelita Brasileiro - MACAB|

1962 Associação Portuguesa Vilanova Artigas de Desportos

$1962 \begin{aligned} & \text { Jabaquara Atlético Vilanova Artigas } \\ & \text { Clube de Santos }\end{aligned}$

\begin{tabular}{lll}
\hline 1962 *Jockey Clube Goiás & Paulo Mendes da Rocha \\
\hline $1962 \quad \begin{array}{ll}\text { *Sede de Campo } \\
\text { do Jóquei Clube de } \\
\text { São Paulo }\end{array}$ & $\begin{array}{l}\text { Sergio Bernardes } \\
\text { e Henrique Pait }\end{array}$ \\
\hline
\end{tabular}

1963 Clubes Recreativo Ícaro de Castro Mello

\begin{tabular}{|c|c|c|}
\hline 1963 & $\begin{array}{l}\text { Tortuga Clube } \\
\text { do Guarujá }\end{array}$ & Vilanova Artigas \\
\hline $\begin{array}{l}1962 \\
-1964\end{array}$ & $\begin{array}{l}\text { Clube XV de } \\
\text { Novembro de Jaú }\end{array}$ & Carlos Millan \\
\hline 1963 & $\begin{array}{l}\text { *Sede do Clube } \\
\text { XV de Santos }\end{array}$ & $\begin{array}{l}\text { Pedro Paulo de Melo } \\
\text { Saraiva e Francisco Petracco }\end{array}$ \\
\hline 1963 & $\begin{array}{l}\text { *Clube da Orla } \\
\text { do Guarujá }\end{array}$ & $\begin{array}{l}\text { Israel Sancovski } \\
\text { e Jerônimo Bonilha Esteves }\end{array}$ \\
\hline
\end{tabular}

1963 Regente Tênis Clube Ícaro de Castro Mello de Regente Feijó 


\begin{tabular}{|c|c|c|}
\hline ANO & CLUBE & ARQUITETOS \\
\hline 1963 & $\begin{array}{l}\text { Esporte Clube } \\
\text { Corinthians } \\
\text { de Presidente Prudente }\end{array}$ & Ícaro de Castro Mello \\
\hline 1963 & $\begin{array}{l}\text { Clube de Regatas } \\
\text { de Piracicaba }\end{array}$ & Ícaro de Castro Mello \\
\hline 1963 & $\begin{array}{l}\text { Umuarama Country } \\
\text { Clube em Guarujá }\end{array}$ & Ícaro de Castro Mello \\
\hline 1963 & $\begin{array}{l}\text { *Sede do } \\
\text { Clube Pinheiros }\end{array}$ & Ícaro de Castro Mello \\
\hline 1964 & $\begin{array}{l}\text { *Clube de Regatas } \\
\text { Paulista Tupã }\end{array}$ & Ícaro de Castro Mello \\
\hline 1964 & $\begin{array}{l}\text { *Clube Sírio Libanês } \\
\text { em Santos }\end{array}$ & $\begin{array}{l}\text { Siegbert Zanettini, } \\
\text { Candido Malta C. Filho, } \\
\text { Manoel K. Corrêa }\end{array}$ \\
\hline 1964 & $\begin{array}{l}{ }^{\star} \text { Clube de Campo da } \\
\text { Associação Paulista } \\
\text { de Medicina }\end{array}$ & $\begin{array}{l}\text { Israel Sancovski, } \\
\text { Jerônimo B. Esteves, } \\
\text { Pedro G. Cury, Nelson } \\
\text { Daruj e Silvano Wendel Filho }\end{array}$ \\
\hline 1964 & $\begin{array}{c}\text { *Sede da Sociedade } \\
\text { Harmonia de Tênis }\end{array}$ & $\begin{array}{l}\text { Fábio Penteado, Alfredo } \\
\text { Paesani e Teru Tamaki }\end{array}$ \\
\hline
\end{tabular}

Segawa (2010) aponta quatro fatores fundamentais para a formação desta nova vanguarda: as discussões políticas e ações da esquerda que antecederam ao golpe militar de 1964; a arquitetura como tema presente no debate público, sobretudo em função da construção de Brasília; São Paulo como principal polo industrial do país e o desenvolvimento da tecnologia nacional do concreto armado; e os cursos de arquitetura das Faculdades de São Paulo (FAU-USP e Mackenzie) que tinham sua origem na escola de engenharia e não nas Belas Artes, como ocorreu no Rio de Janeiro.

O início da década de 1960 foi marcado por um turbulento período político, dominado pela pressão dos grupos reacionários, formados pela Igreja Católica, militares e setores importantes da sociedade civil, que culminou na intervenção militar em 1964.

Com forte respaldo civil, o exército passou a controlar o país em uma escalada conservadora, a qual determinou graves consequências para o campo da arquitetura. A começar pelo fechamento de diversos periódicos, como a Revista Módulo, que encerrou suas atividades em 1965, até a perseguição de professores universitários como, por exemplo, Artigas, que foi preso logo após o golpe de 1964, esteve exilado no Uruguai, retornou à FAU-USP em 1967 e foi definitivamente afastado após o Ato Institucional n.o 5 (AI5) em 1969, retornando à universidade apenas após a anistia em 1979.

"projetos realizados a partir de concursos 


\section{NOTAS 1}

Disponível em: https://censo2010.ibge.gov.br/sinopse/ index.php?dados=8. consultado em: 10/11/19.

2 Disponível em: <http://enciclopedia.itaucultural.org.br/ obra36386/ministerio-da-educacao-e-saude-publicario-de-janeiro-rj>. Acesso em: 1 de Dez. 2019.

3 MINDLIN, A nova arquitetura e o mundo de hoje. Conferência pronunciada pelo arquiteto Henrique E. Mindlin na Escola de Engenharia Mackenzie, em 30/8/45. In YOSHIDA, Celia Ballario, et. al. Henrique Ephim Mindlin: O Homem e o Arquiteto. São Paulo: Instituto Roberto Simonsen / Federação e Centro das Indústrias do Estado de São Paulo, p.165-172.

4 ANDRADE, Mario de, Brazil Builds (1944). In: Depoimento de uma geração. Organização Alberto Xavier. São Paulo: Cosac Naify, 2003, p.179.

5 Disponível em: https://www.archdaily.com.br/br/01-12832/ classicos-da-arquitetura-conjunto-residencial-prefeitomendes-de-moraes-pedregulho-affonso-eduardo-reidy/ nabil-bonduki_4-copia/. Acesso em: 11 abr. 2019.

6 Disponível em: https://www.archdaily.com.br/ $\mathrm{br} / 758700 /$ classicos-da-arquitetura-museude-arte-moderna-do-rio-de-janeiro-affonsoeduardo-reidy/5483c5f3e58ecefOed000063centro_de_documentacao_e_pesquisa_do_mam_1-jpg Acesso em: 11 abr. 2019.

7 Disponível em: https://www.archdaily.com.br/br/867716/ ultima-semana-para-visitar-a-exposicao-quecelebra-os-60-anos-do-projeto-de-lucio-costa-parabrasilia/58d29744e58ecef1270000b6-ultima-semana-para-visitar-a-exposicao-que-celebra-os-60-anos-do-projetode-lucio-costa-para-brasilia-foto . Acesso em: 11 abr. 2019

8 Disponível em: https://www.archdaily.com.br/br/0181125/brasilia-em-construcao-por-marcel-gautherot/ foto-marcel-gautherotims-3/ . Acesso em: 11 abr. 2019.

9 Disponível em: https://www.archdaily.com.br/br/01-17010/ classicos-da-arquitetura-casa-modernista-da-rua-santacruz-gregori-warchavchik/5627b767e58ece127a000256classicos-da-arquitetura-casa-modernista-da-rua-santacruz-gregori-warchavchik-imagem . Acesso em: 11 abr. 2019.

10 Disponível em: https://www.archdaily.com.br/br/01-163168/ classicos-da-arquitetura-casa-modernista-da-rua-itapolisslash-gregori-warchavchik/5280d040e8e44e95f60000b1classicos-da-arquitetura-casa-modernista-da-rua-itapolisslash-gregori-warchavchik-imagem . Acesso em: 11 abr. 2019.

11 Disponível em: http://www.vilanovaartigas.com/ cronologia/projetos/casinha . Acesso em: 11 abr. 2019
12

Disponível em: http://www.vilanovaartigas. com/cronologia/projetos/casa-rio-brancoparanhos. Acesso em: 11 abr. 2019.

13 Disponível em: http://www.vilanovaartigas.com/cronologia/ projetos/edificio-louveira . Acesso em: 11 abr. 2019.

14 Disponível em: http://www.vilanovaartigas.com/cronologia/ projetos/rodoviaria-de-londrina . Acesso em: 11 abr. 2019.

15 Disponível em: https://iO.wp.com/capsula.arq. br/wp-content/uploads/2017/10/CAP-AR-19UniteDHabitation-4.jpg . Acesso em: 11 abr. 2019.

16 Disponível em: https://elarafritzenwalden.tumblr.com/ post/184016909029/smithdon-school-hunstantonnorfolk-east-of/embed . Acesso em: 11 abr. 2019.

17 Disponível em: http://www.vilanovaartigas.com/cronologia/ projetos/casa-olga-baeta. Acesso em: 11 abr. 2019.

18 Disponível em: http://www.vilanovaartigas.com/cronologia/ projetos/casa-olga-baeta. Acesso em: 11 abr. 2019.

19 Disponível em: http://www.vilanovaartigas.com/cronologia/ projetos/ginasio-de-itanhaem. Acesso em: 11 abr. 2019.

20 Disponível em: http://www.vilanovaartigas.com/cronologia/ projetos/ginasio-de-itanhaem. Acesso em: 11 abr. 2019.

21 Disponível em:http://www.vilanovaartigas.com/cronologia/ projetos/ginasio-de-guarulhos. Acesso em: 11 abr. 2019.

22 Disponível em: http://www.vilanovaartigas.com/cronologia/ projetos/ginasio-de-guarulhos. Acesso em: 11 abr. 2019.

23 Disponível em:http://www.vilanovaartigas.com/cronologia/ projetos/ginasio-de-guarulhos. Acesso em: 11 abr. 2019.

24 Disponível em:http://www.vilanovaartigas.com/cronologia/ projetos/ginasio-de-guarulhos. Acesso em: 11 abr. 2019.

25 Disponível em: https://www.archdaily.com.br/ br/01-139826/classicos-da-arquitetura-ginasio-doclube-atletico-paulistano-slash-paulo-mendes-darocha-e-joao-de-gennaro/522e07b6e8e44e260100002bclassicos-da-arquitetura-ginasio-do-clube-atleticopaulistano-slash-paulo-mendes-da-rocha-e-joao-degennaro-imagem?next_project=no. Acesso em: 11 abr. 2019.

Disponível em: https://www.archdaily.com.br/br/01-139826/ classicos-da-arquitetura-ginasio-do-clube-atleticopaulistano-slash-paulo-mendes-da-rocha-e-joao-degennaro/522e07abe8e44e333b00002e-classicosda-arquitetura-ginasio-do-clube-atletico-paulistanoslash-paulo-mendes-da-rocha-e-joao-de-gennaroimagem?next_project=no. Acesso em 11 de Abr. 2019. 

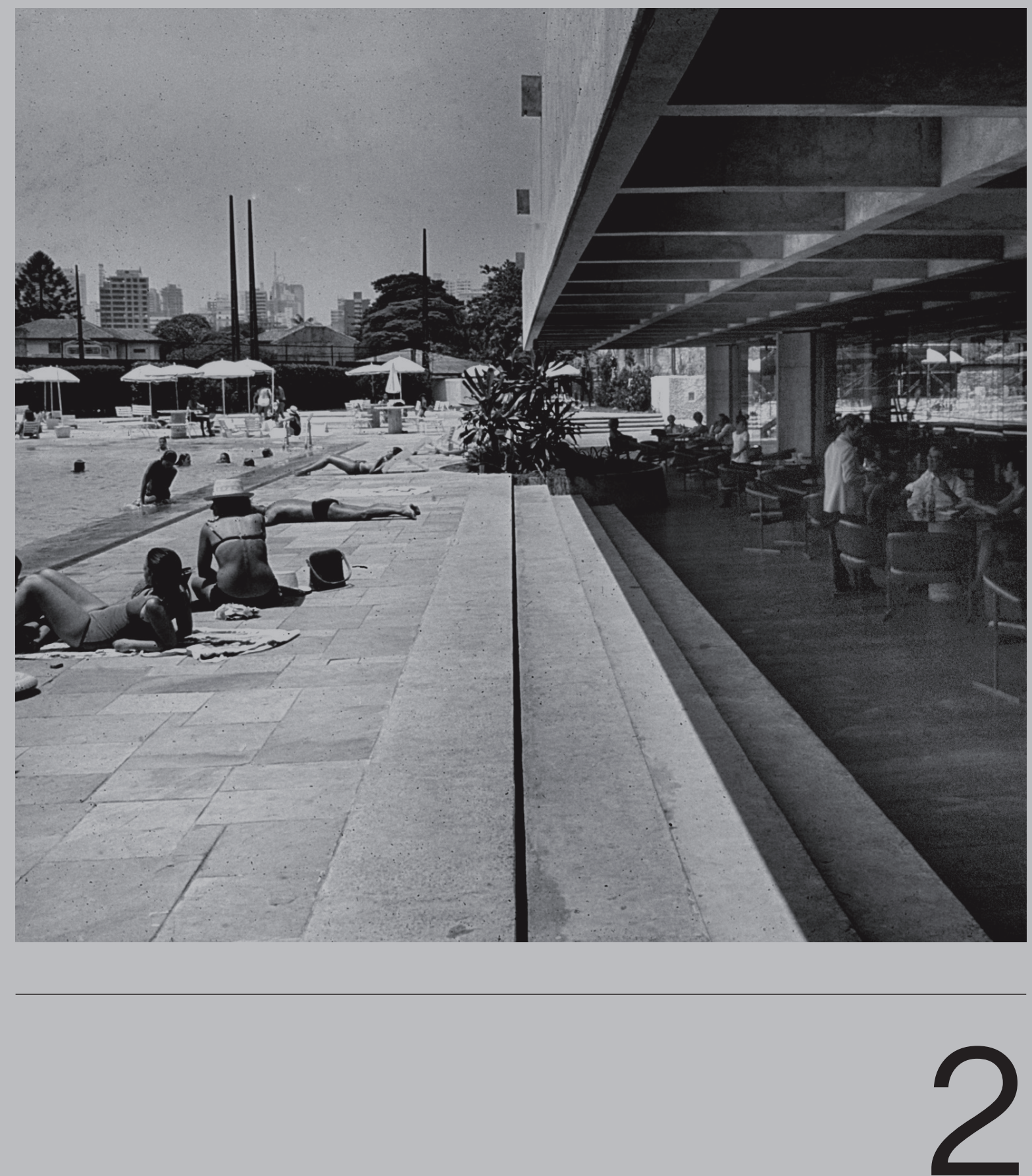
ANTECEDENTES 


\section{BAIRRO JARDIM AMÉRICA}

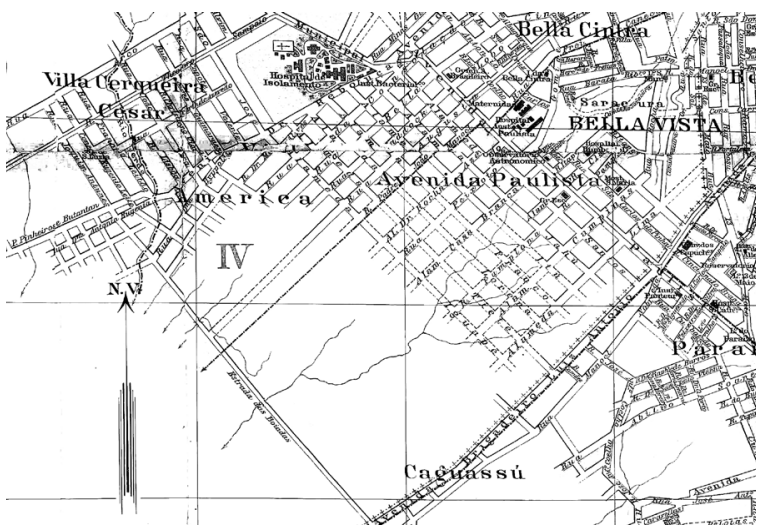

1912

A Sede da Sociedade Harmonia de Tênis, objeto deste estudo, está localizada na rua Canadá, 658 no bairro do Jardim América, o primeiro bairro-jardim da cidade de São Paulo.

O Jardim América foi planejado no início do século XX pela City of São Paulo Improvements and Freehold Land Company Limited. A empresa, sediada na Inglaterra e estabelecida em São Paulo no ano de 1911, foi estruturada por um grupo de empreendedores internacionais, que vieram ao Brasil a convite do arquiteto Joseph-Antoine Bouvard (1840-1920) e do diretor de Obras Públicas do município, Eng. Victor da Silva Freire (1869-1951).

Neste período, a cidade crescia economicamente de maneira exponencial e se tornou uma enorme oportunidade para a empresa desenvolver operações imobiliárias e de urbanização. Com a consultoria de Freire, a City obteve orientação para adquirir aproximadamente doze milhões de metros quadrados de terras, o equivalente a $37 \%$ da área urbana da cidade daquele tempo, e

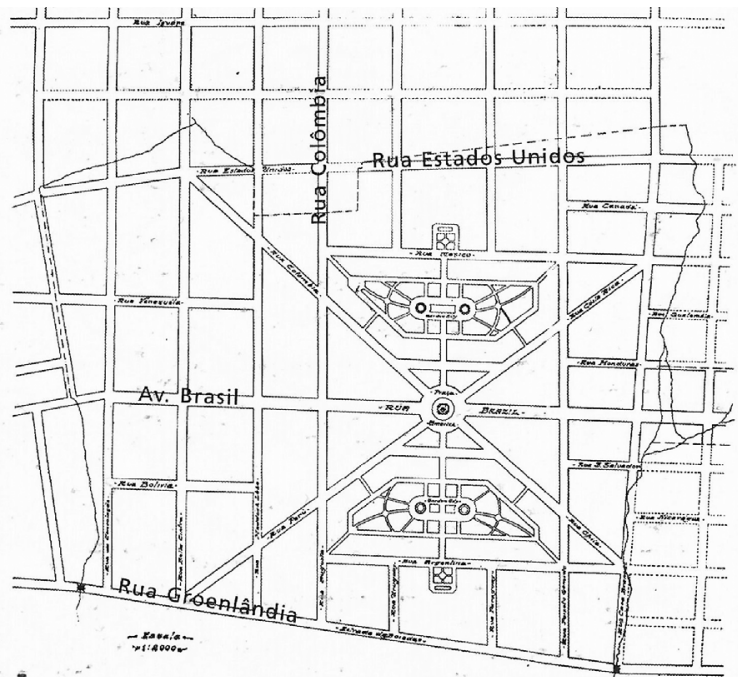

1913

organizar o que se tornaria o maior empreendimento fundiário na história do município de São Paulo.

Em janeiro de 1912, foram adquiridos os terrenos para o loteamento do Jardim América, localizados abaixo da Villa Cerqueira César, em direção às área alagadiças da várzea do rio Pinheiros, conformando uma área de 1.091.118m2.

É possível que o primeiro plano para o Jardim América tenha sido realizado em 1913 por Bouvard, consultor do belga Édouard-Émile-Albert de Laveleye, Barão de Laveleye (1854-1938), financista da empresa City. O projeto previa a continuidade das vias ortogonais que desciam o vale e se organizava em forma de tabuleiro de xadrez, com exceção ao cruzamento em X na avenida Brasil.

Para o desenvolvimento dos projetos definitivos de seus loteamentos, a City contratou os arquitetos Raymond Unwin (1963-1940) e Barry Parker (1867-1947). A renomada dupla de profissionais era a mesma que havia projetado Letchworth, a primeira cidade-jardim, e Hampstead, o primeiro subúrbio-jardim, em Londres.
$30 \uparrow$ Mapa da região da Av. Paulista, 1913 Fonte: Página Prefeitura Municipal de São Paulo.
$31 \uparrow \quad$ Primeiro Plano Jardim América Fonte: (WOLFF, 2001, p. 130). 


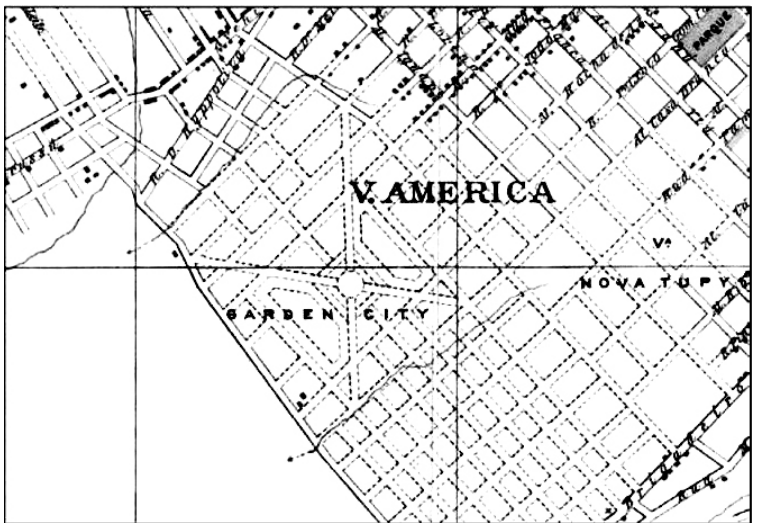

1913

A cidade de Letchworth (1903), localizada ao norte de Londres, foi a primeira experiência concreta ao plano teórico e utópico concebido por Ebenezer Howard (1850-1928). A proposta de Howard descrita em " $T o$ -morrow: A peaceful path to real reform" de 1898, resumidamente, pode ser tratada como uma:

(...) proposta urbanística de uma cidade autônoma, de dimensões controladas, e forte vínculo com a natureza, que se oporia à perda de escala e de humanidade identificada na grande metrópole industrial que Londres já era. (WOLFF, 2017, p. 221)

A cidade-jardim de Howard não visava fins lucrativos: a terra era adquirida por uma sociedade anônima e paga pelos indivíduos que a compunham sem a perspectiva de se tornarem proprietários. Em Letchworth os terrenos foram cedidos em aluguel por 99 anos. Dentre os princípios fundamentais estavam:
"1. eliminação da especulação; 2. controle da expansão e limitação da população; 3. equilíbrio funcional entre a cidade, o campo, as residências, o comércio, a indústria, a função espiritual, política, social e recreativa, com a finalidade de evitar a "depressão moral" e econômica dos subúrbios operários; 4 . planejamento do empreendimento sob sérias bases econômicas.” (GIORDANI, 1972, p.63 apud BACELLI, 1982, p. 44)

Os "três ímãs" propostos por Howard para a cidade-jardim preconizavam dentre outros objetivos: oportunidades sociais, liberdade, cooperação, preços baixos, nenhuma exploração.

O segundo projeto para o Jardim América, realizado em 1915, é somente de Raymond Unwin, que mantém os eixos geométricos básicos do primeiro projeto. No entanto, a proposta intitulada Garden City, tem seu traçado viário orgânico, remetendo ao urbanismo dos subúrbios anglo-americanos, com tratamento paisagístico no canteiro central da Avenida Brasil, praças públicas e onze jardins no centro de quadras para uso exclusivo da vizinhança imediata. Havia ainda a intenção de se construir um distrito comercial, no cruzamento da rua Colômbia com a Avenida Brasil, com 17 lojas e

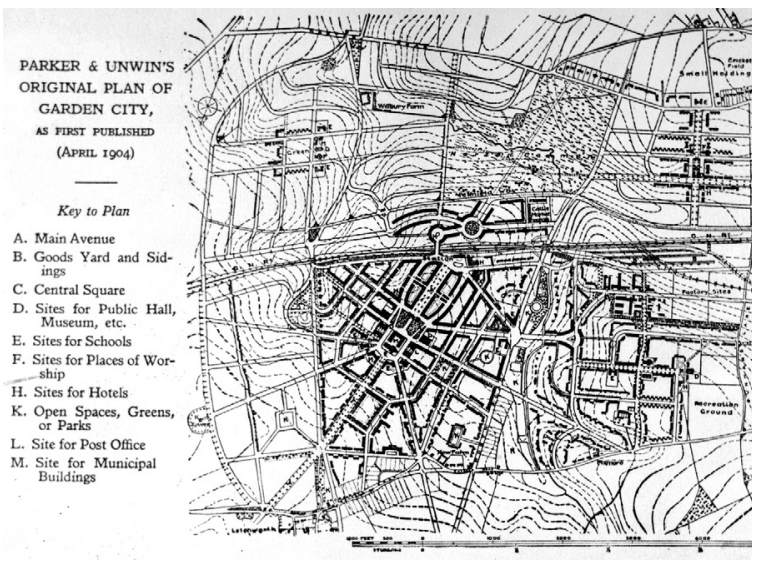

$32 \uparrow$ Primeiro Plano Jardim América inserido no mapa da cidade de São Paulo Fonte: (GOTO e MONTEIRO, 2019, p. 2).
$33 \uparrow$ Projeto para Letchworth, 1904 Fonte: Página Snail in the City. ${ }^{2}$ 


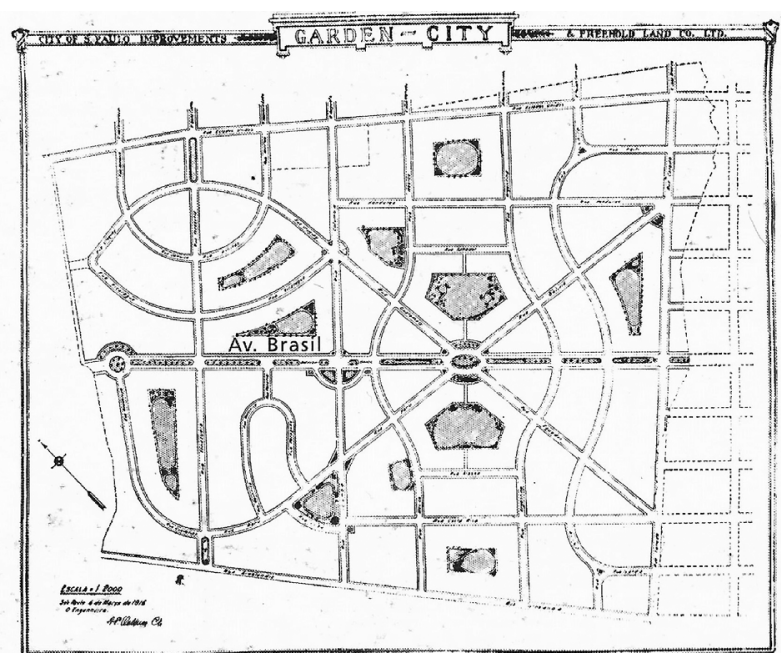

1915

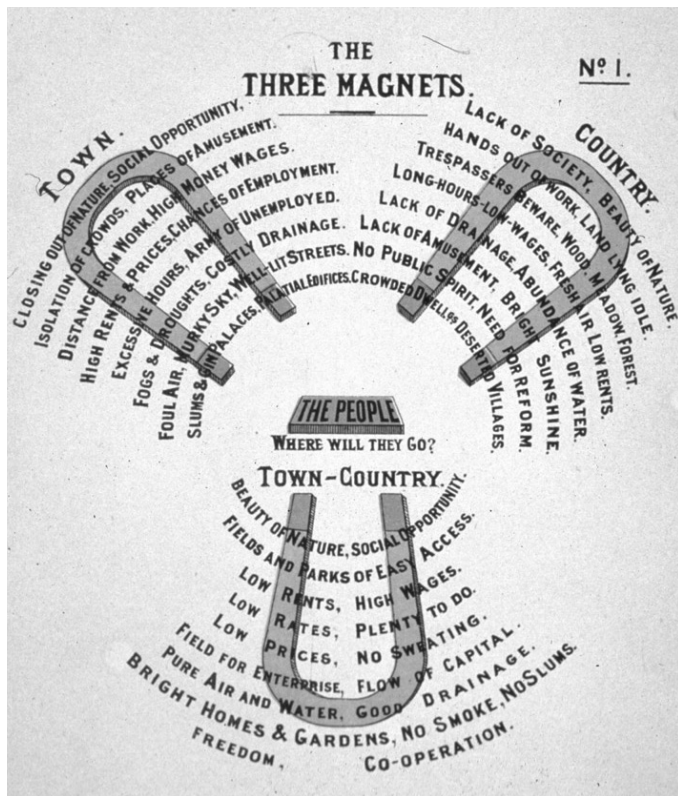

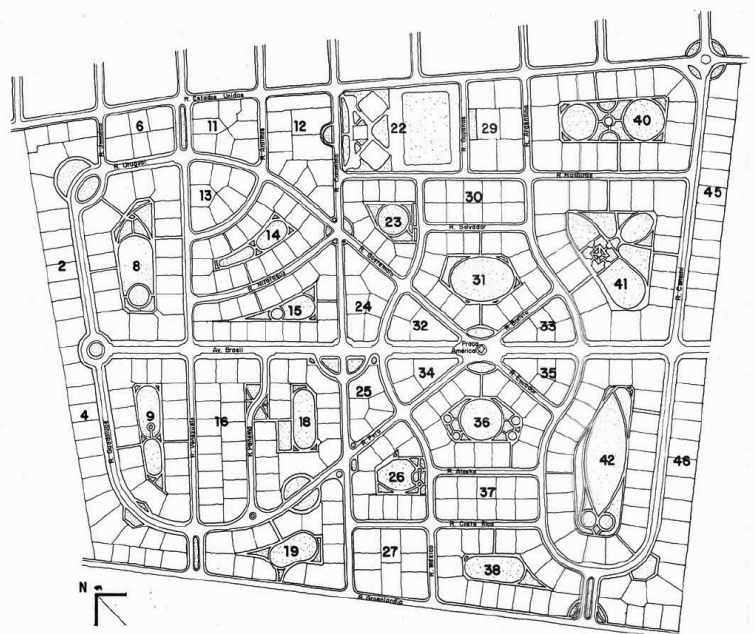

1919

armazéns, sendo vedado o comércio em outras áreas do loteamento.

As demais alterações que se sucederam, até o ano de 1940 , foram realizadas por Barry Parker. No projeto que foi efetivamente implantado, de 1919, delimitado pelas ruas Estados Unidos, Groenlândia e Canadá, nota-se a presença do Clube Atlético Paulistano e quatorze jardins de uso irrestrito nos centros de quadras, interligados às vias públicas por passagens estreitas exclusivas aos pedestres.

Os terrenos adquiridos para o Jardim América eram áreas de charco, distantes e enlameadas. Para possibilitar a implantação do loteamento, a partir de 1913, as terras foram drenadas, aterradas e dotadas de infraestrutura. Em consonância aos interesses da City, foram realizados diversos acordos com os departamentos públicos do Estado e com as companhias particulares para a instalação das infraestruturas de rede de água, esgoto, gás e luz elétrica. Em 1914 a prefeitura concluiu a pavimentação da rua Augusta até a rua Estados Unidos, possibilitando

$36 \uparrow$ Plano Jardim América, 1919

Fonte: (BACELLI, 1982, p. 70 e 71).
$34 \uparrow$ Segundo Plano Jardim América

$35 \uparrow$ Três Ímãs de Howard

Fonte: Página Massachusetts Institute of Technology 


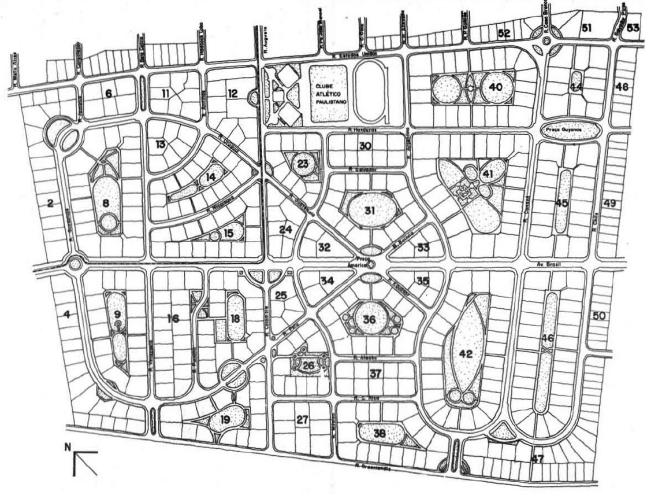

1925

a extensão da linha de bondes que interligou o Jardim América até o centro da cidade.

Seis anos após o início das obras, em 1919, a empresa realizou o lançamento de vendas do empreendimento. A Cia. City estabeleceu um conjunto de regras para a construção de novas edificações no loteamento com o objetivo de estabelecer um padrão ambiental. Foram definidas as taxas máximas de ocupação, o controle dos afastamentos laterais, recuos mínimos em relação à frente e fundos do lote, os limites para o gabarito de altura, altura de gradis de divisa, dentre outras regras.

Estes parâmetros foram utilizados nos demais loteamentos da empresa e, em certa medida, incorporados nas posturas municipais de controle urbano. Exemplo maior da receptividade do poder público ocorreu no planejamento do bairro do Pacaembu. Para alinhar as regras da municipalidade aos projetos propostos pela City, em 1923, a prefeitura estabeleceu diversas alterações na legislação municipal, dentre elas a criação de áreas estritamente residenciais, a redução da largura

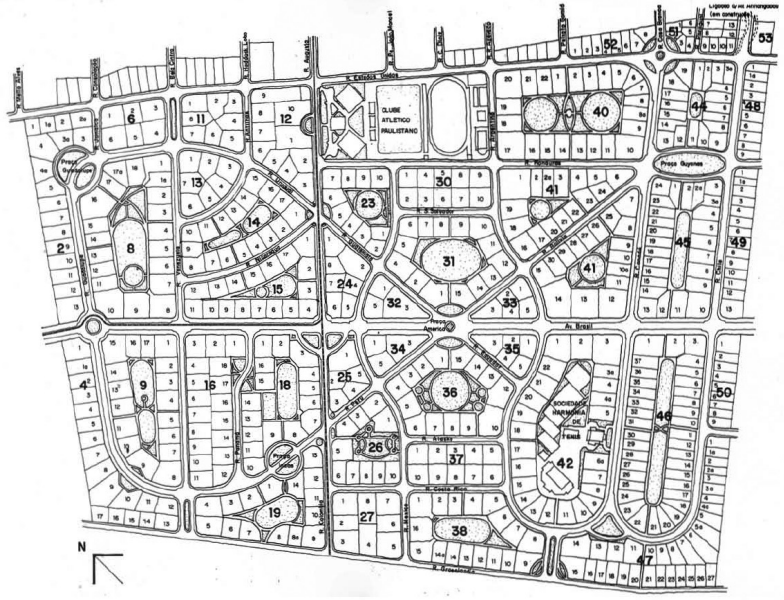

1929

mínima das ruas para viabilizar a implantação do loteamento do Pacaembu, acomodado às curvas de nível do vale, a possibilidade de vias com traçados sinuosos e a não obrigatoriedade do traçado xadrez.

Após quatro anos do lançamento de vendas, em 1925, já haviam cerca de cem casas construídas no Jardim América. Para ampliar a oferta nesse loteamento, a City adquiriu terras vizinhas ao empreendimento e Parker desenvolveu um novo projeto para incorporar a expansão do loteamento, implantando as quadras adjacentes à rua Chile e três novos jardins nos centros das quadras 44, 45 e 46. O terreno do Clube Atlético Paulistano incorporou a quadra 29, suprimindo a rua Guyanas. Neste local estava construído o Estádio Jardim América, com capacidade para 15.000 torcedores. $^{3}$

A partir do mapa produzido pela City of São Paulo em 15 de maio de 1929, é possível verificar a Sociedade Paulista de Tennis ocupando a área central da quadra 42, delimitada pelas ruas Canadá, Argentina e Avenida Brasil.
$37 \uparrow$ Plano Jardim América, 1925 Fonte: (BACELLI, 1982, p.72 e 73).
$38 \uparrow$ Plano Jardim América, 1929

Fonte: Acervo Museu Paulista da USP. 


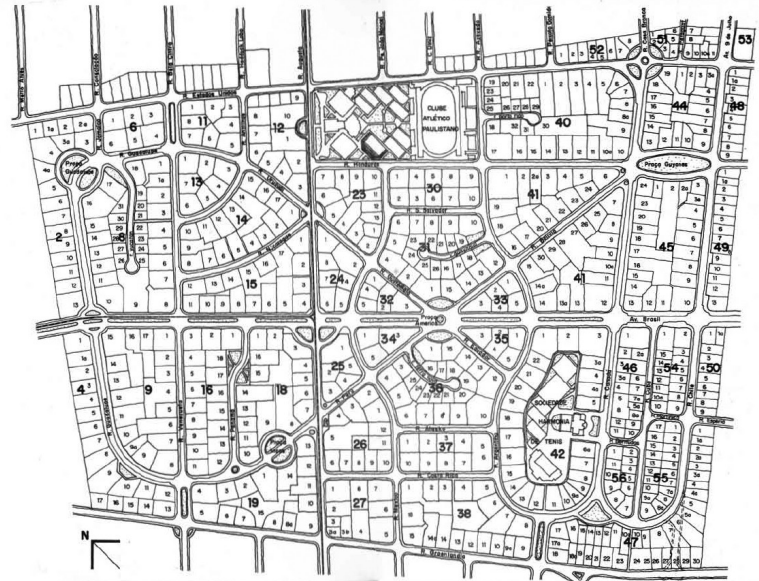

1941

A empresa se tornou detentora dos direitos de fiscalização e parcelamento da área do loteamento até os anos 1940. Neste período realizou diversas alterações no plano original; a mais evidente ocorreu com a supressão dos jardins internos. As áreas de lazer em estilo vitoriano eram um dos grandes diferenciais de venda do empreendimento e um item inovador no urbanismo da cidade.

A City, que se responsabilizava pela manutenção dos jardins internos, na tentativa de transferir tal encargo, propôs a divisão das despesas entre os proprietários de lotes lindeiros. Por serem locais de acesso público, os moradores não aderiram ao plano da empresa. A Companhia também não obteve sucesso na tentativa de transmissão da responsabilidade de manutenção para a prefeitura.

Como solução, a City extinguiu os jardins internos e transformou estas áreas em lotes privados para venda, seja através de novas ruas sem saída, nos moldes cul de sac, seja ofertando para a venda dos lotes

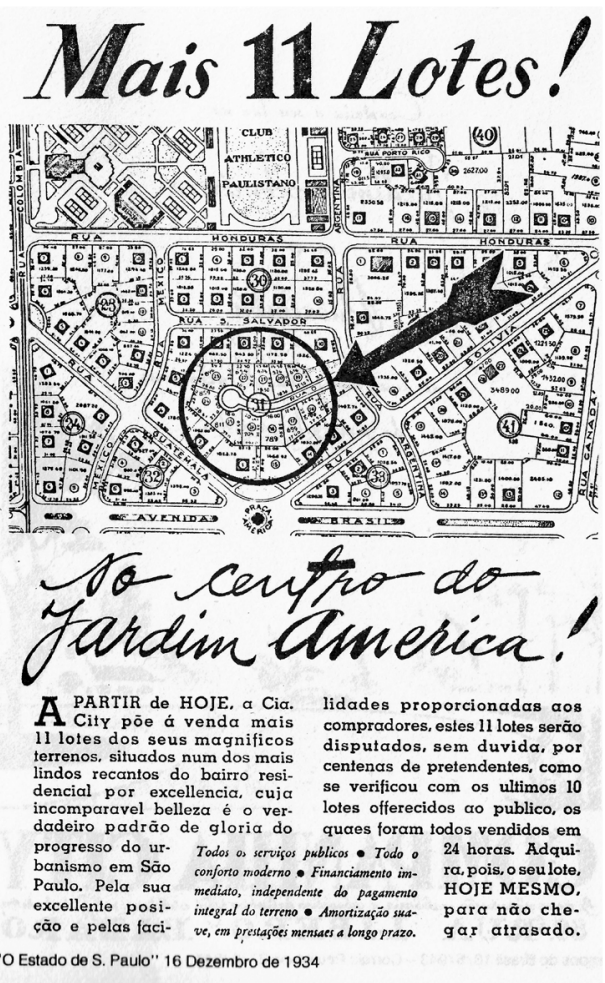

remanescentes aos proprietários das quadras. Estas alterações ficam evidentes no anúncio de vendas de 1934 e no mapa de 1941.

No mapa de 1941, também é possível ver a recém-inaugurada avenida 9 de Julho, primeira grande via integratória do Plano de Avenidas de Prestes Maia (1896-1965) construída fora do centro de São Paulo. Localizada sobre o córrego do Saracura e o córrego Iguatemi, interligou a rua Estados Unidos, na altura da rua Chile, ao Largo da Memória, e contribuiu com a lógica de valorização das áreas nos fundos de vale e das várzeas mais distantes do centro da cidade.

Os prospectos desenvolvidos para a comercialização dos lotes tratavam o Jardim América como o "bairro perfeito" e relacionavam, dentre as suas qualidades, o urbanismo moderno, as redes de infraestrutura urbana e transporte, os clubes seletos e as alamedas verdejantes de linhas sinuosas que o distinguiam do restante da cidade.

Embora houvesse a proibição da construção de empreendimentos não residenciais no loteamento, a empresa
$39 \uparrow$ Plano Jardim América, 1941 Fonte: (BACELLI, 1982, p. 76 e 77 ).
$40 \uparrow$ Anúncio de vendas, 1934 Fonte: (BACELLI, 1982, p. 115). 
permitiu a construção de dois clubes seletos e uma igreja: O Clube Atlético Paulistano, considerado pela City, desde o lançamento do empreendimento, um dos fatores de desenvolvimento e valorização do Jardim América; a Sociedade Paulista de Tennis, que mais tarde tornou-se Sociedade Harmonia de Tênis; e a igreja Nossa Senhora do Brasil, que, segundo Andrade:

vai se caracterizar por atender parte significativa da elite católica da Capital, foi reforçado o caráter altamente segregador do Jardim América, aproximando-o mais de um enclave, ainda que sem muros visíveis. (ANDRADE, 2002)

Concebido como um empreendimento a ser ofertado e adquirido exclusivamente pelo público de alto poder aquisitivo, pautado pela propriedade privada e valorização imobiliária, o Jardim América:

em nada se assemelhava às utopias de cunho socialista que marcaram o século XIX, de caráter fortemente coletivista - como no caso da proposta de cidade-jardim de Howard. (ANDRADE, 2002)

Em virtude de seu valor paisagístico, o bairro e a região dos Jardins foram tombados pelo CONDEPHAAT (Resolução SC 2, de 23/1/1986) no ano de 1986, consolidando o alto padrão de ocupação de seus lotes.

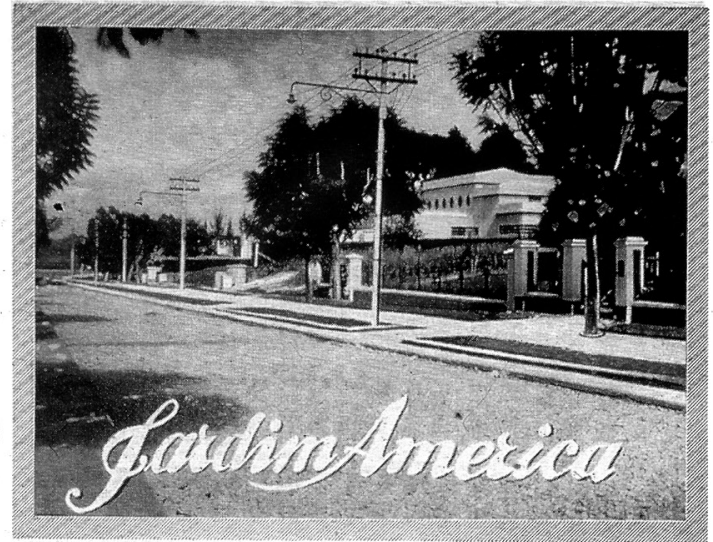

- o bairto

É U.MA verdadeira maravilha, E sob os differentes aspectos do moderno urbanismo, o Jardim Ameriea, Bairo residencial por excellencia, possue toto o conforto proprio do nosso tempo: agua, erpotos, illuminaçâo publica, luz, gaz c tolephone, alem de optimos servicos de bondes e omuibus, tque cortum em. varias thireseós as suas principace arterias, lodos

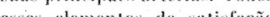

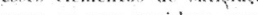

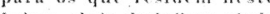
bairro. cheio de behrea, anda sîo enriquecidos com a presenca, constantemente feutiva, garrida, saudavel. de centenas de creanęas. noças - eséolares, athletas, nadadores e ten nistas, que frequentale seus bons cofllexios selectos clubs socisectos chibivo

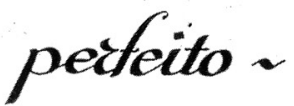

As amplas e verdejantes alamedas do Jardim America, nas linhas sinuosas e acolhedoras desceus detalhes, como nas lihat rectas c puras de seu tracado peral, são, simultunca-

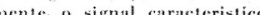
- amoldura adeyunda do

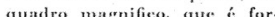

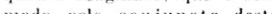

Vas ruas Chile e Canadá, no Praca Guyanas, nas ruas Cuba, Martiniata e Bermudas, anda dispomos de varios lotes de terreno, situados nos trecho: que foram recentemente abertos ao publico. Alli, tamben, já se desfructam todas as com-

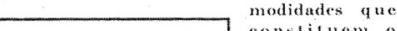
Escalina HOJE o sen lote, constituem fuara a constructä́ de ama conforto moder no: oproprio Financizmento IMMEDIATO do asphaltudo AManciamono $M$ MMEDIATO Dramencho -Jardim Amedofagamento integraldoterreno, rica é o baire perfeito!

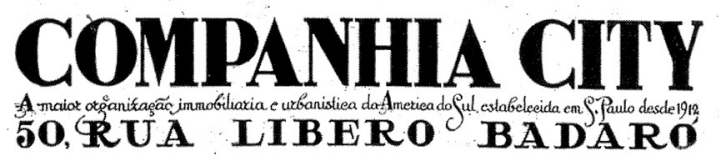




\section{SOCIEDADE HARMONIA DE TÊNIS}

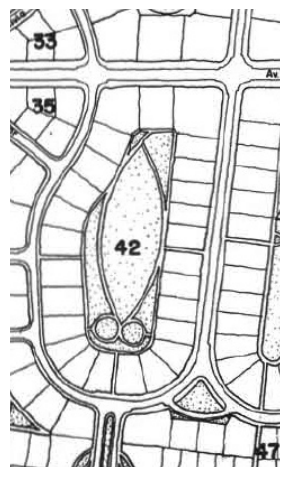

1919

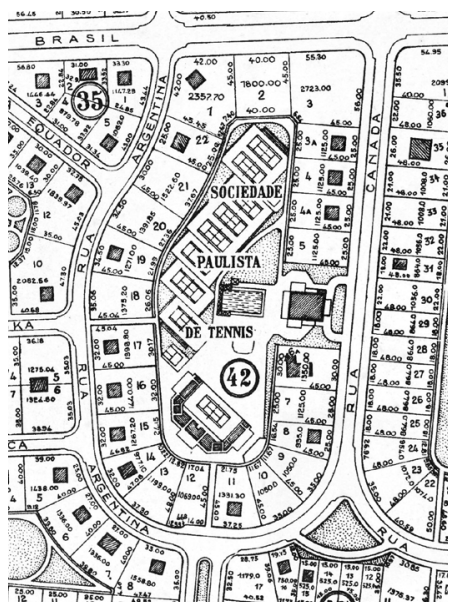

1929

A Sociedade Harmonia de Tênis está implantada na praça central da quadra 42, delimitada pelas ruas Canadá, Argentina e Avenida Brasil no bairro do Jardim América.

Conforme mencionado anteriormente, os jardins centrais das quadras do loteamento foram projetados inicialmente por Unwin em 1915, para uso privativo dos moradores dos lotes lindeiros. Na alteração do projeto, realizada por Parker em 1919, os jardins tornaram-se acessíveis ao público. Na Quadra 42 a interligação ocorre nas ruas Argentina e Canadá, por meio de três vielas para passagem de pedestres.

Em 1929 a Sociedade Paulista de Tennis firmou acordo com a City para adquirir a posse desse jardim. A ocupação da área ocorreu na condição dos 24 proprietários de lotes contíguos se tornarem sócios do clube. $\mathrm{O}$ acesso dos moradores às instalações ocorria por um portão aberto no muro dos fundos de cada terreno. Quando um vizinho mudava ou falecia, a passagem era lacrada definitivamente. A última foi fechada no final da década de 80 .

\footnotetext{
$42 \uparrow$ Detalhe do Plano Jardim América, 1919 Fonte: (BACELLI, 1982, p. 70 e 71).

$43 \uparrow$ Plano Jardim América, 1929
}

Fonte: Acervo Museu Paulista da USP.

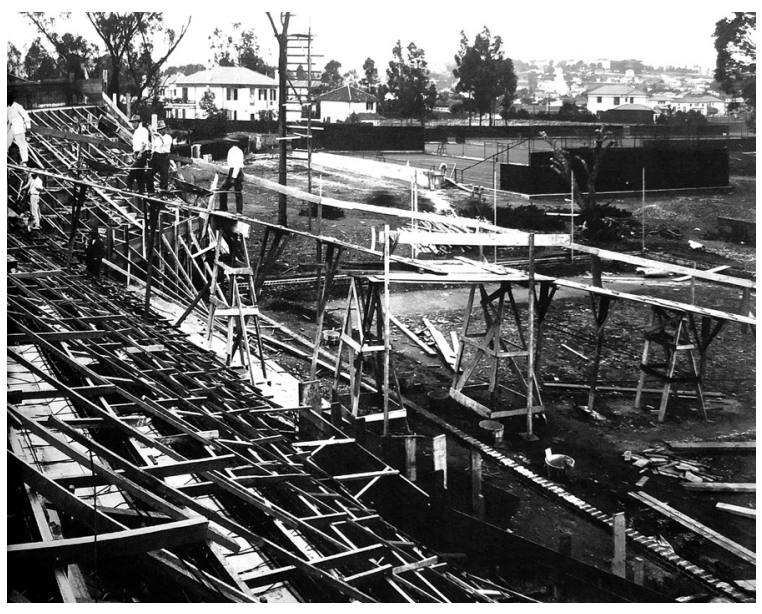

1929

A Sociedade Paulista de Tennis era formada por um grupo de rapazes que utilizava as quadras do Clube Paulistano e encontraram nesta região a oportunidade implantar as instalações necessárias para aprimorar e desenvolver este esporte introduzido no Brasil na virada do século XX por trabalhadores ingleses da Light e da São Paulo Railway.

Inicialmente, construíram oito quadras de tênis e o Estádio Anésio Lara Campos. Inaugurado oficialmente em 19 de abril de 1930, o estádio possui arquibancadas em concreto armado com capacidade para 1500 pessoas e seguia todas as normas técnicas para receber torneios internacionais.

Em 1930, foi oficializada a união entre os representantes da Sociedade Paulista de Tennis e as moças da Sociedade Harmonia de Danças, organizadoras dos bailes do Trianon. Em ata de 26 de julho de 1930: "O sr. Presidente comunica que foram ultimadas as tratativas para a incorporação da Sociedade Paulista de Tênis à Sociedade Harmonia de Danças, que modificará o seu

$44 \uparrow$ Construção do Estádio de Tênis, 1929 Fonte: (PENTEADO, 1998, p. 171). 


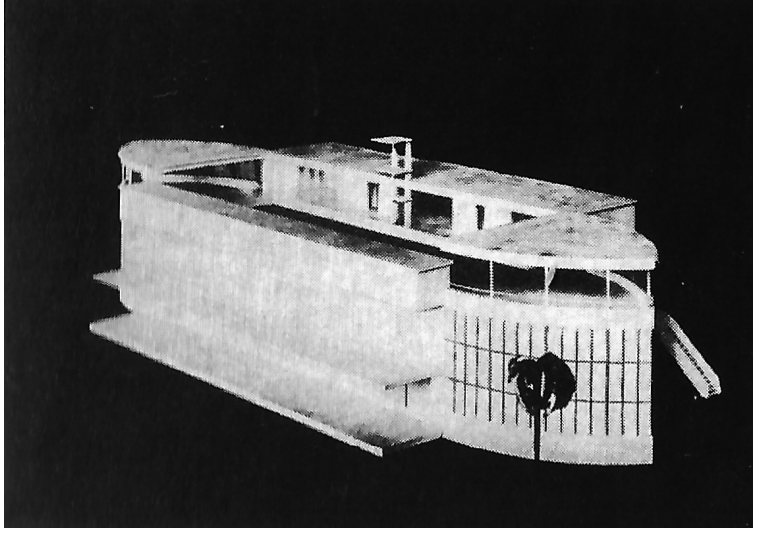

nome para Sociedade Harmonia de Tênis...” (GORDINHO, 1993, p. 1)

Para a construção da primeira sede, o clube utilizou-se dos recursos advindos da venda dos terrenos localizados nos bairros da Água Branca e Barra Funda, pertencentes à extinta Sociedade Harmonia de Danças, somados aos empréstimos com a Cia. City e verbas arrecadadas entre os sócios. As obras para a construção da primeira sede do clube iniciaram em 1934 e foram entregues em 1935, juntamente com uma das primeiras piscinas da cidade.

O clube Harmonia, em sua história, promoveu ao menos três importantes concursos para construção da sua sede:

acredita-se que a primeira sede tenha sido edificada a partir de um concurso realizado em 1929, no qual há registros de duas propostas - uma do arquiteto russo radicado em São Paulo, Gregori Warchavchik, outra de Jaime da Silva Telles. (PENTEADO, 1998, p. 171)
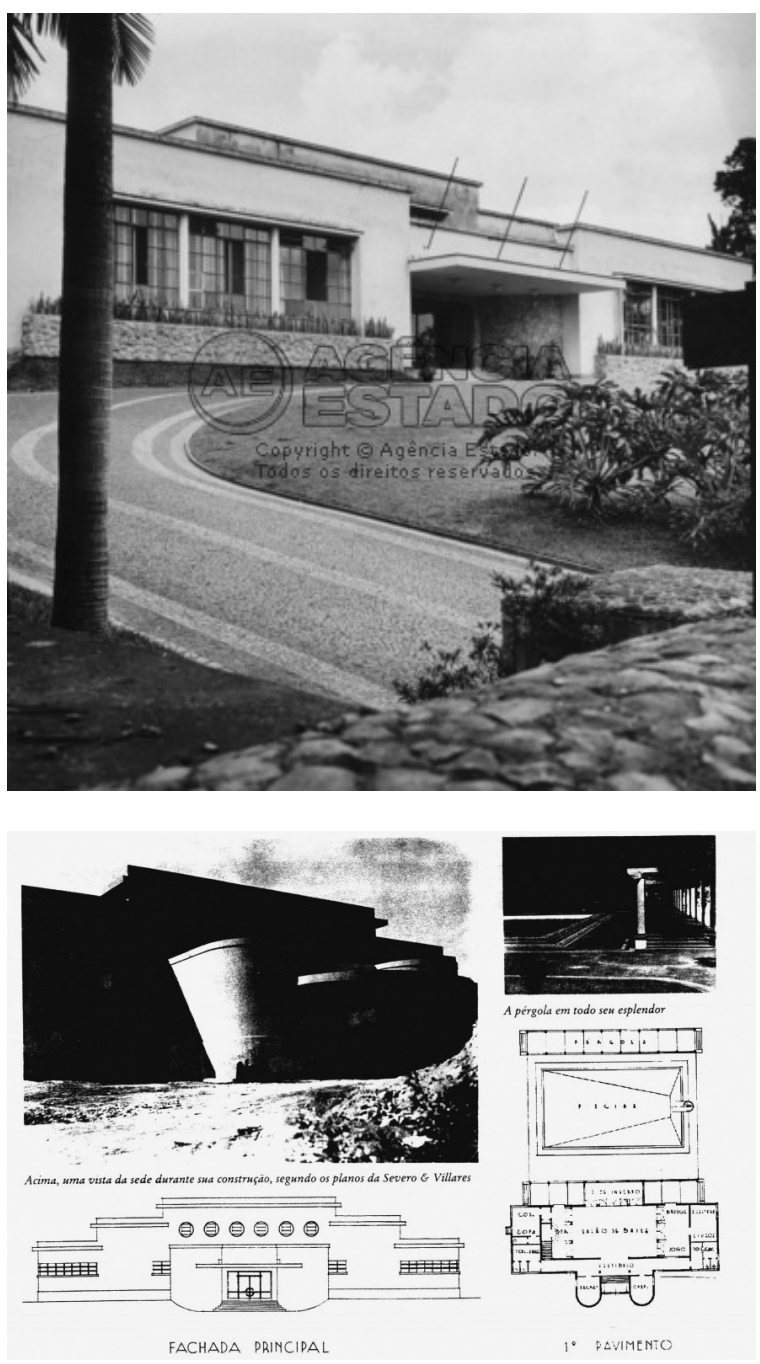

1. PAVIMENTO
$45 \uparrow$ Projeto para o Edifício Sede de Gregori Warchavchik Fonte: (PENTEADO, 1998, p. 171).
$46 \uparrow$ Fachada do Edifício Sede, década de 1930 Fonte: Agência Estado.

$47 \uparrow$ Edifício Sede, década de 1930

Fonte: (GORDINHO, 1993, p. 4). 


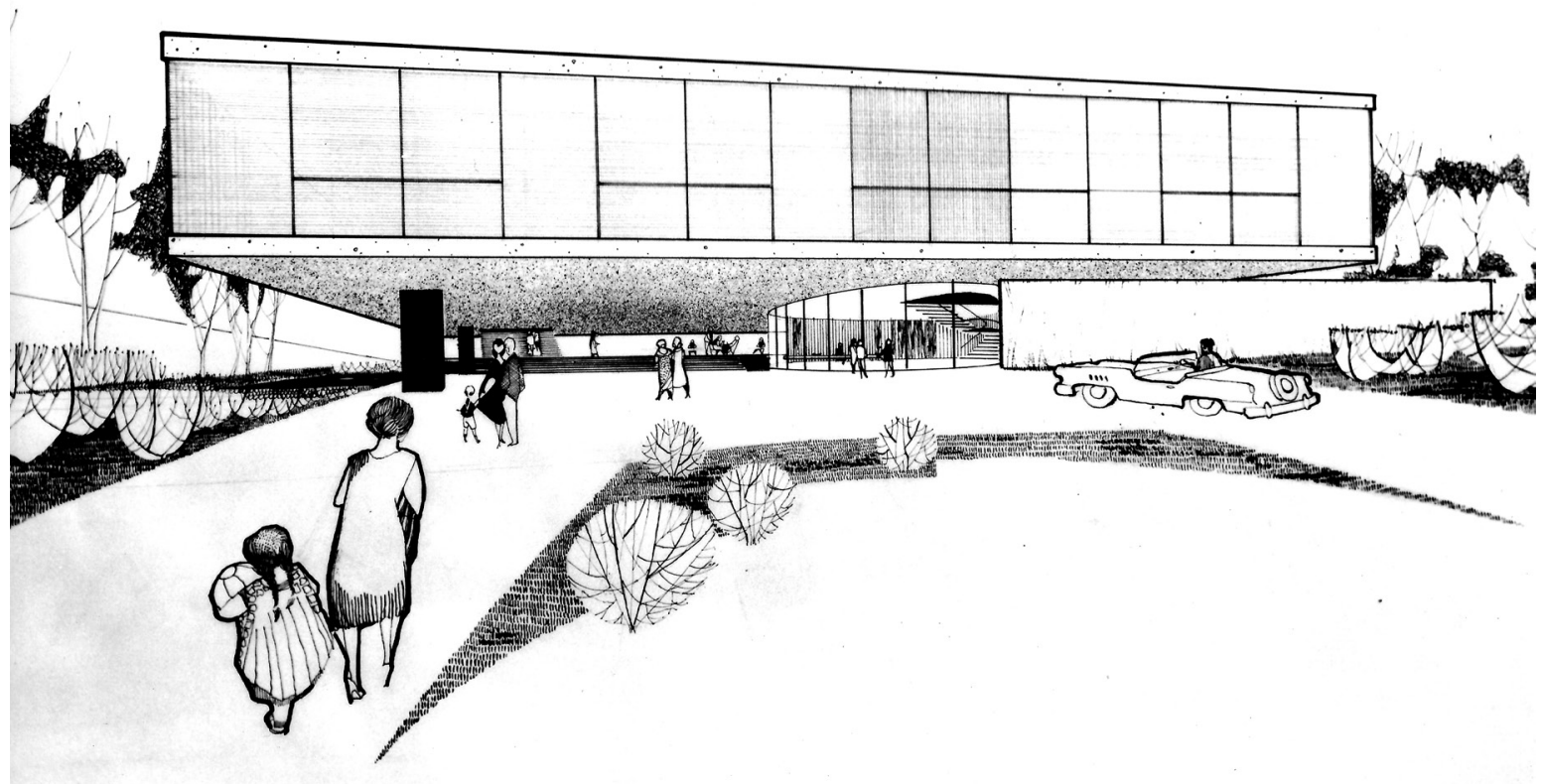

O edifício construído em art déco pelo escritório de engenharia Severo \& Villares, sinalizava a modernidade do clube que contrastava com a arquitetura paulistana da época. O edifício possuía salão de baile, copa, cozinha, toaletes, sala de leitura e sala de jogo para a prática de bridge, antes praticado sob as arquibancadas do estádio.

O clube foi fundado em 1930, com aproximadamente trezentos sócios. Em 1948, o quadro de sócios passou para 1.250. Com emissão de novos títulos, o clube adquiriu recursos para a primeira reforma da sede.

Na década de 1950 o Harmonia registrava 2.585 sócios. Para adequar sua infraestrutura ao aumento de público, em 1958 o Clube e o Instituto de Arquitetos do Brasil promoveram um concurso de arquitetura para o qual convidaram 72 profissionais renomados, dentre os quais 28 apresentaram propostas.

Dentre as atividades do Harmonia, destacavam-se a prática de tênis, bridge e os eventos sociais, com bailes e formaturas. Atendendo às principais demandas do clube, o programa do edital solicitava uma sede com salões de estar, jogos, restaurante, boite e um departamento esportivo completo, incluindo duas quadras de tênis cobertas.

Um dos sócios do clube, o arquiteto Fábio Penteado, formado a apenas cinco anos, venceu o concurso em parceria com Luís Forte Neto (1936) e José Maria Gandolfi (1933). Segundo reportagem da revista Acrópole

A principal característica do projeto vencedor, foi a obtenção de grandes áreas livres ajardinadas, dando ao Clube um espírito adequado às suas finalidades.

(REVISTA ACRÓPOLE, 1960, p. 193) 
O projeto com $6.375 \mathrm{~m} 2$ de área construída previa o faseamento de sua implantação em três etapas, sendo a última a demolição do Estádio Anésio Lara Campos para a construção das duas quadras cobertas. Por falta de verbas, as obras não foram iniciadas.

Em 1962, o Clube realizou uma nova emissão de títulos e adquiriu da City o terreno do extinto jardim central com $18.280 \mathrm{~m} 2$, até então utilizado a título precário com a necessidade de submeter todas as benfeitorias à aprovação da empresa loteadora. Anexado ao lote da Sede, com frente para a rua Canadá, o Clube tornou-se proprietário efetivo de $21.000 \mathrm{~m} 2$.

No ano de 1964, o Harmonia contava com aproximadamente 4.500 sócios e teve o projeto para uma nova sede desenvolvido pelo arquiteto Antônio Luiz de Anhaia Mello. Ao ser informado dos planos do clube, Fábio Penteado, vencedor do concurso de 1958, sugeriu para a diretoria a realização de um novo concurso. Segundo o próprio arquiteto:

(...) houve um concurso, em 1958, e meu grupo ganhou. Porém, foi encomendado outro projeto, mais de acordo com a linha de pensamento predominante no clube.

Em 1964, quando já haviam implantado parte desse projeto e iam começar a sede, constataram que ele era impraticável. Fiquei sabendo disso por meio de um conselheiro que era meu amigo e o convenci a distribuir entre os membros do conselho - mais ou menos cem pessoas - dez exemplares da revista Acrópole, que tinha meu projeto na capa. Houve surpresa, porque ninguém conhecia o trabalho.

Esse meu amigo propôs então que eu fosse convidado a participar novamente. Houve confusão, porque já existia até candidato a fazer tudo. No final, fizeram um novo concurso, do qual participaram o autor do projeto que tinha parado, Anhaia Melo, e eu. (Penteado, 2004)

Em 29 de outubro de 1964 o clube instituiu um novo concurso, também organizado pelo IAB, mas desta vez fechado, no qual concorreram apenas os arquitetos Antônio Luiz de Anhaia Mello e Fábio Penteado.

O júri foi coordenado por outro sócio do clube, o arquiteto Júlio Neves, e composto por Ícaro de Castro Mello, Roberto Carvalho Franco e Rubens Carneiro Vianna, que declararam como vencedor o projeto de Fábio Penteado, em parceria com Teru Tamaki e Alfredo Paesani.
O contrato para o projeto executivo de arquitetura foi assinado em 16 de dezembro de 1964. As obras iniciaram no ano seguinte e a nova sede do clube foi oficialmente inaugurada em 1970.

Em 1 de outubro de 1981 foi enviada ao então presidente do CONDEPHAAT (Conselho de Defesa do Patrimônio Histórico, Arqueológico, Artístico e Turístico), arquiteto Ruy Ohtake, a carta contendo a solicitação de estudos para tombamento do Edifício-Sede da Sociedade Harmonia de Tênis, descrevendo a obra como exemplar significativo da arquitetura contemporânea brasileira. A carta é assinada por treze arquitetos, entre eles Ícaro de Castro Mello, Geraldo Vespasiano Puntoni, Jon Andoni Vergareche Maitrejean, Júlio Neves, Oswaldo Corrêa Gonçalves, Pedro Paulo de Melo Saraiva, Paulo Mendes da Rocha e Eduardo Kneese de Mello. Em 7 de dezembro de 1981 o CONDEPHAAT comunica, através de ofício, a abertura do processo 21.901/81 para estudos de tombamento do edifício.

Dez anos depois da abertura do processo, em carta de 14 de abril de 1992, o colegiado do CONDEPHAAT aprova, por unanimidade, o tombamento do edifício. Neste período, o órgão havia deferido o tombamento apenas de cinco obras de arquitetura moderna: o edifício da FAU-USP, de Vilanova Artigas em 1981; o edifício-sede da Fazenda Capuava, de Flávio de Carvalho em 1981; o edifício do MASP, de Lina Bo Bardi, em 1982; a Casa Modernista da rua Santa Cruz, de Gregori Ilych Warchavchik, em 1984; e o edifício Esther de Alvaro Vital Brasil, em 1990, tornando-o um dos primeiros edifícios modernistas tombados em São Paulo.

No decorrer dos cinquenta anos de existência do Harmonia, inúmeras obras ocorreram em suas dependências e três lotes lindeiros foram incorporados ao clube. Algumas das benfeitorias foram projetadas por Penteado como obras de acessibilidade, adequações pontuais no edifício-sede e a construção do novo estacionamento e piscina localizados no lote justaposto ao edifício. 


\section{AUTORES DO PROJETO}

A equipe de arquitetos que desenvolveu o projeto para a Sede da Sociedade Harmonia de Tênis em 1964 era integrada por: Fábio Penteado (1929-2011) e Alfredo Paesani (1931-2010), formados pelo Mackenzie, respectivamente nos anos de 1953 e 1954, e Teru Tamaki, formado pela FAU-USP, no ano de 1961.

Penteado realizou ao menos 12 projetos em parceria com Paesani, entre os anos de 1956 e 1968. Teru iniciou a sua participação no escritório de Penteado recém formado, em 1963, e o acompanhou até o ano de 2002 produzindo ao menos 53 projetos juntos.

No período em que trabalharam juntos, entre 1963 e 1968, Penteado, Paesani e Tamaki produziram ao menos três projetos entre os mais importantes de suas carreiras: a Sede Social do Clube Harmonia (1964); o Teatro Ópera de Campinas (1966) - segundo colocado no Concurso Nacional do IAB e ganhador da Grande Medalha de Ouro na I Quadrienal de Teatro em Praga -, e o Centro de Convivência de Campinas (1967).

Penteado se refere aos colegas como:

O Teru, que é sempre uma pessoa muito amiga, generosa, a gente fazia projeto junto e ele fazia andar o projeto, assim como foi o Paesani. No caso do Harmonia, sem o Paesani eu não poderia fazer. A ideia é uma ideia, mas toda a minúcia de um projeto de arquitetura competente é extremamente necessária.

(GIROTO, 2013, p. 433)

Alfredo Paesani nasceu em São Paulo no ano de 1931, formou-se engenheiro-arquiteto no ano de 1954. Durante a faculdade, estagiou no escritório de Oswaldo Bratke e no escritório Croce, Aflalo \& Gasperini, ambos reconhecidos pela produção de desenhos rigorosos e minuciosos.

Recém formado, trabalhou com Pedro Paulo de Melo Saraiva, com quem venceu o concurso para o prédio da Assembleia Legislativa de Santa Catarina em 1957, e participou da equipe de Ícaro de Castro Mello, Fábio Penteado, Eduardo de Almeida, Paulo Mendes da Rocha e Vilanova Artigas.

Na lista de obras do Plano de Ação do Governo Carvalho Pinto - PAGE, aparece como autor do projeto para o Fórum Firmino Whitaker, em Mogi Mirim (1959), Grupo Escolar de Araçatuba (1960), EE Prof. Laurindo Vieira Pinto, em Ibiúna (1961) e EE Dom Barreto, em Campinas (1962).

Sempre trabalhou em parcerias e nunca abriu um escritório para desenvolver a sua carreira solo. Em entrevista à Revista Projeto (2004, n. 299), Paesani afirmou que:

(...) a parte criativa nunca foi a mais importante para mim. Eu colaborava, mas, em geral, os outros se encarregavam da criação. Depois tinha a parte executiva, nessa eu ia a fundo. Depois de alguns anos comecei a participar também das obras. Eu me interessava por especificações, queria entender as novas técnicas. (PAESANI, 2005)

Participou ativamente da gestão do IAB, entre os anos de 1959 e 1961 e entre 1968 e 1971 . Compareceu a um congresso em Moscou com Lúcio Costa e outro em Cuba, do qual foi organizador. Foi fundador do Sindicato de Arquitetos de São Paulo (SASP), ocupando o cargo de presidente da instituição entre os anos de 1971 e 1974. Em 1977 foi um dos fundadores da Revista Projeto, ao lado de Fábio Penteado e fundador da Federação Nacional de Arquitetos e Urbanistas, ocupando a presidência em 1980.

Quando diretor técnico da CECAP (Caixa Estadual de Casas para o Povo), atual Companhia de Desenvolvimento Habitacional e Urbano do Estado de São Paulo (CDHU), participou da construção do Conjunto Zezinho Guimarães, em Guarulhos (SP). Encerrou a carreira de arquiteto no ano 2000 aos 69 anos e faleceu dez anos depois.

Teru Tamaki nasceu em 1934 e se formou pela FAU-USP em 1961; aparece como colaborador no projeto vencedor do concurso para o Clube Sírio Libanês de Santos (1964) de Cândido Malta C. Filho e Manoel K. Correa.

Sua trajetória como arquiteto está intimamente ligada ao escritório de Fábio Penteado. Tornou-se professor da FAU-USP em 1986, local em que lecionou até o ano de 2002. Produziu uma série de livros sobre poesia e arquitetura entre os anos de 1993 e 2010. 


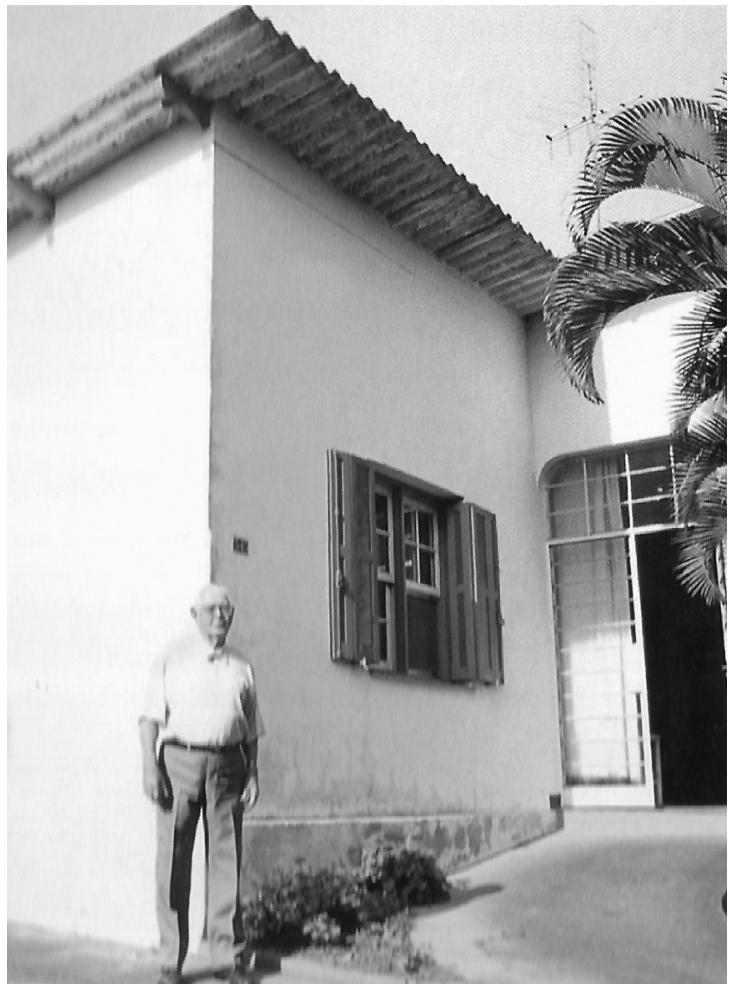

Penteado se refere ao colega:

O Teru foi amigo de 30 anos, um profissional de extrema competência, mas se ele estivesse sozinho também não faria. Então a gente foi andando junto. Eu acho que em todos os grandes trabalhos ele sempre foi fundamental. Sem estar junto com o Teru eu não teria feito grande parte das coisas. (GIROTO, 2013, p. 433)

Fábio Penteado nasceu em Campinas no ano de 1929, neto de engenheiro e filho de industrial. Mudou-se com a família para São Paulo aos seis ano e viveu boa parte de sua vida no bairro de Higienópolis, onde estudou no Colégio Ophélia Fonseca, na época uma tradicional escola da cidade.

Conforme relato do arquiteto, aos 18 anos entrou em último lugar para o curso de arquitetura da Universidade Mackenzie. A graduação ocorreu entre os anos de 1948 e 1953, num período em que a escola, recém emancipada do curso de engenharia (12 de agosto de

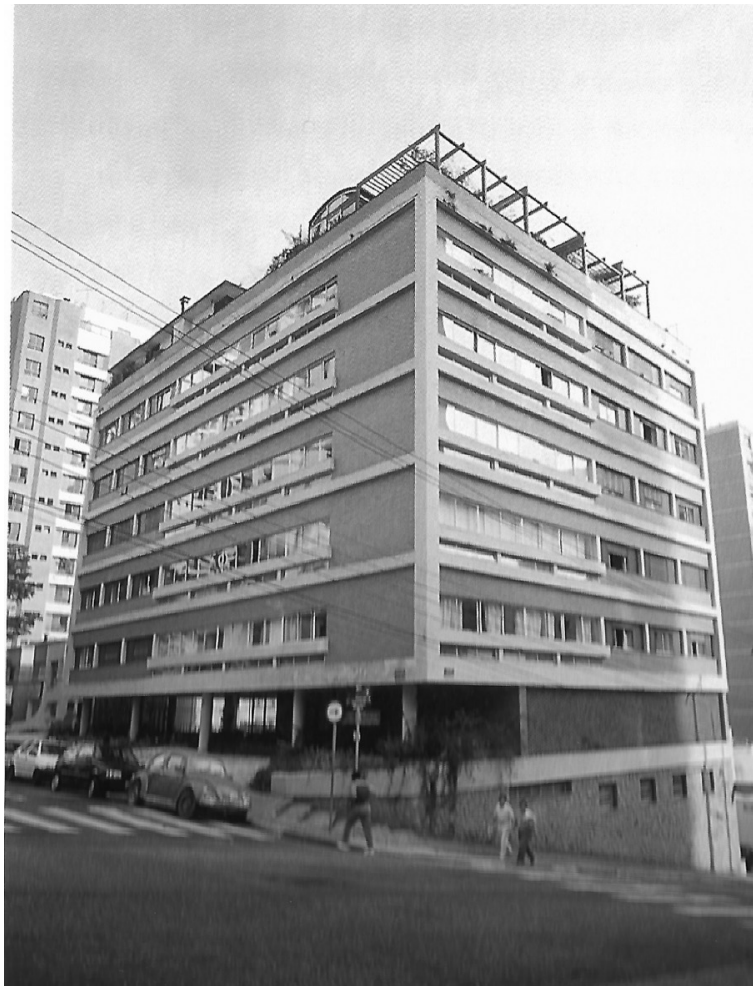

1947) era dirigida por Cristiano Stockler das Neves (1889-1982). O diretor defendia a preservação das tradições clássicas e combatia qualquer indício de modernidade. Não só publicava críticas contra Le Corbusier e Oscar Niemeyer nos principais jornais da cidade, como também proibia a citação de seus nomes em sala de aula "por cometerem uma arquitetura comunista" (PENTEADO, 1998, p. 19).

No Mackenzie, Penteado foi contemporâneo de Carlos Millan, (1927-1964) Paulo Mendes da Rocha, (1928) João Eduardo de Gennaro, (1928-2013) Jorge Wilheim, (1928-2014) Pedro Paulo de Mello Saraiva, (1933-2016) Telésforo Cristófani, (1929-2002) Roberto Aflalo, (1926-2002) Djalma Macedo Soares, Alfredo Paesani, (1931-2010) José Carlos Ribeiro de Almeida, (1938-2005) Alberto Botti, (1931) Júlio Neves, (1932) João Kon (1933), entre outros.
$49 \uparrow$ Residência de Domingos Solha Fonte: (PENTEADO, 1998, p. 22).
$50 \uparrow$ Edifício na rua Itacolomi Fonte: (PENTEADO, 1998, p. 22). 


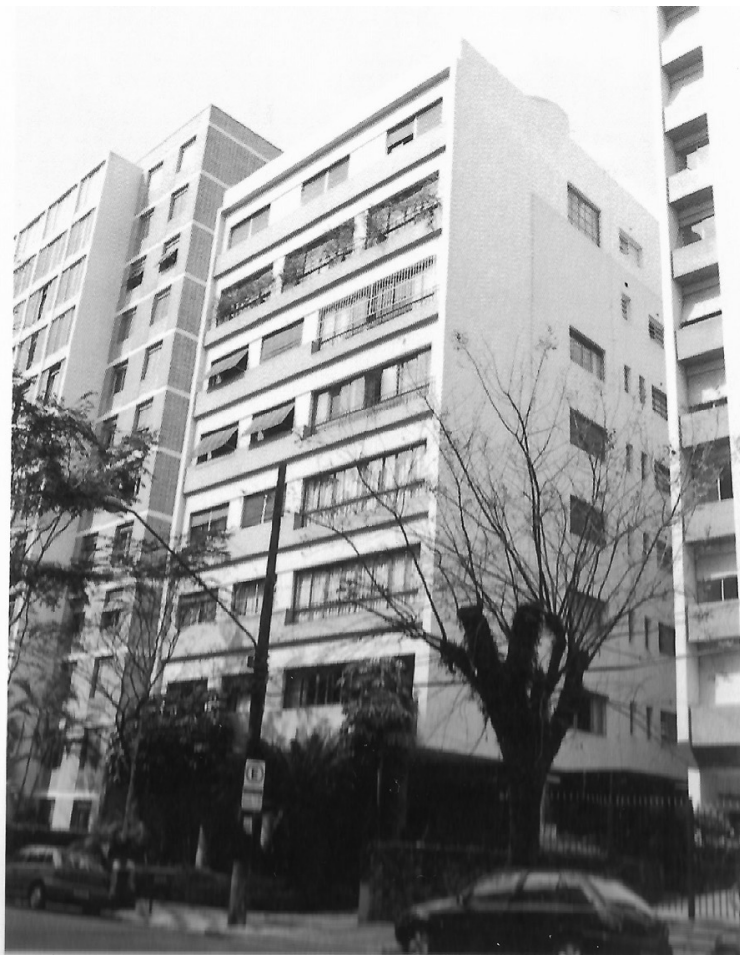

No Mackenzie o ensino era dirigido pelo arquiteto Christiano Stockler das Neves, que em sua obsessão pela arquitetura acadêmica, se comportava como um verdadeiro paladino na luta contra tudo o que fosse ligado à arquitetura moderna. (..) Me valeu muito, naquele tempo, a convivência com alguns colegas, como o Carlos Millan, que se não tivesse desaparecido tão cedo, em 1965, teria sido, sem dúvida, o melhor arquiteto da minha geração.

O Millan fazia uma espécie de ensino subterrâneo dentro da escola, e havia alguns outros - como o Telésforo Cristófani, o Alfredo Paesani, o Pedro Paulo Saraiva, o Paulo Mendes da Rocha - um grupo de uns dez ao todo, que se reunia às quintas-feiras num atelier de Desenho Artístico e lá se discutia sobre tudo, até sobre arquitetura. (PENTEADO, 1983, p. 17-18)

Formado em 1953, aos 24 anos, Fábio já possuía um notável reconhecimento pelo 2.o lugar no concurso promovido pelo IAB para um Hotel em São Carlos (1953), ao lado dos colegas Pedro Paulo de Mello Saraiva e Djalma Macedo Soares e dois projetos construídos: a residência de Domingos Solha, em Souzas, Campinas (1948), e um edifício de apartamentos na rua Itacolomi (1951) em São Paulo. Ainda no seu último ano de formação, projetou em parceria com Stipan Dragutin Milicic, o Edifício Residencial Alameda Franca (1953), o qual finalizaram no ano de 1954, logo após a sua formação.

Em 1954, Penteado abriu o seu primeiro escritório na rua Riachuelo, centro de São Paulo. Fato recorrente em toda a sua trajetória profissional são os projetos em coautoria. Em entrevista a Giroto, o arquiteto expôs a sua necessidade:

(...) Talvez pela minha formação deficiente, eu posso crer que eu sou um bom pensador, mas eu não sou um bom fazedor. (GIROTO, 2013, p. 433)

Nos primeiros dez anos de vida profissional (1954 a 1964) suas múltiplas parcerias são majoritariamente formadas com seus colegas do Mackenzie e com o iugoslavo Milicic, que trabalhou no Brasil entre 1950 e 1970. Desde os primeiros projetos que desenvolveu, Penteado já demonstrava apreço aos concursos de arquitetura e projetos de maior escala como clubes, hotéis edifícios públicos e privados, além de obras de infraestrutura.

No período em que estava estabelecido na Rua Riachuelo, Penteado conquistou alguns prêmios e produziu projetos de grande envergadura dos quais podemos destacar: o primeiro lugar no concurso Sede do Clube Campineiro, (1954) com Milicic; o Prêmio Governador do Estado no III Salão Paulista de Arte Moderna, com o projeto para a Estação de Tratamento de Água de São Bernardo do Campo, (1954) com Ringo Kubota e Milicic, e a Estação de Tratamento de Água Campinas II, (1956) com Alfredo Paesani, na qual faz uma clara alusão aos projetos da Escola Carioca, com a instalação de um painel de azulejo do artista Mário Gruber (1927-2011).

A convite de Kneese de Mello, (1906-1994) mudou o seu escritório para o edifício-sede do Instituto de Arquitetos de São Paulo (IAB SP) em 1956. Ocupando uma das salas do 6.0 andar do IAB, pode conviver com um dos pontos mais animados da cidade, onde se reuniam intelectuais, artistas, jornalistas e estudantes em geral. Lá estavam alguns dos engenheiros-arquitetos mais importantes de São Paulo formados pela Escola Politécnica da USP (POLI) como Ícaro de Castro Mello

$51 \uparrow \quad$ Edifício Alameda Franca

Fonte: (PENTEADO, 1998, p. 22) 

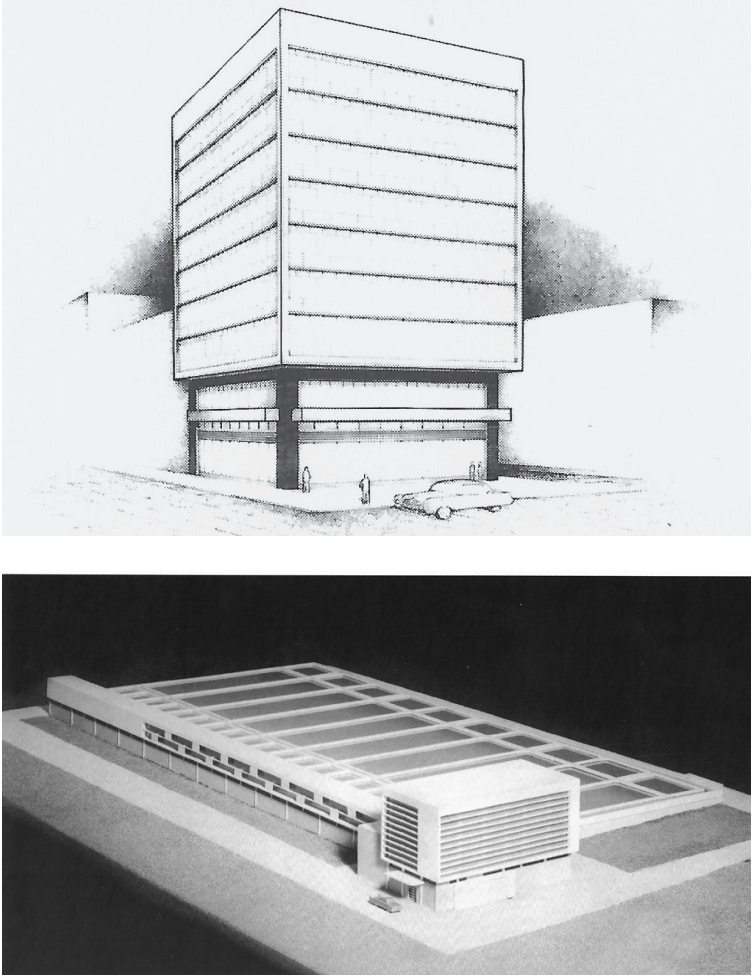

(1913-1986) em 1935, Vilanova Artigas em 1937 e Oswaldo Corrêa Gonçalves (1917-2005) em 1941, os engenheiros-arquitetos formados pelo Mackenzie Eduardo Kneese de Mello em 1931 e Miguel Forte (1915-2002) em 1939, além de Rino Levi, formado na Escola Superior de Arquitetura de Roma em 1926.

No IAB, em 1956, Penteado recebeu o convite para se tornar editor de arquitetura da Revista Visão, periódico de maior importância na época, à qual se dedicou até 1962. Sua função era informar o grande público sobre as obras de arquitetura de todo o Brasil.

Sempre me pareceu muito importante comentar os projetos a partir de suas 'memórias', mas me intrigava verificar se elas continham quase sempre intenções humanísticas de grande beleza, essas intenções dificilmente permaneciam no produto final, na obra construída. Da minha passagem pelo jornalismo o que mais marcou foi essa constatação e creio que a partir de então, busquei expressar esta preocupação, inclusive nos meus projetos. (PENTEADO, 1983, p. 19)

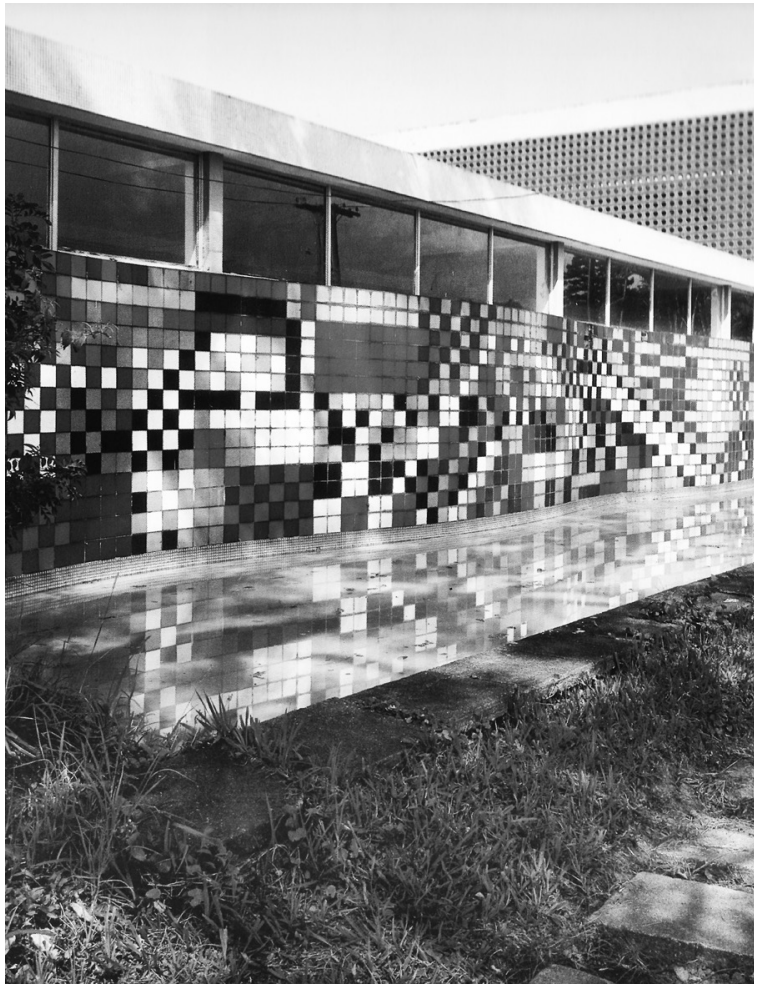

Os encontros entre os arquitetos mais experientes e estudantes promoviam o debate por uma arquitetura nacional. A partir de uma crítica frontal aos padrões de individualidade estabelecidos, a nova arquitetura estava fundamentada na valorização dos espaços coletivos e da cidade, como abrigo para a população que nela se estabelecia. Neste período, é possível verificar uma inflexão na atuação de Penteado, que vai se desdobrar em toda a sua obra subsequente. Para Penteado, o projeto para o Hotel Praia do Peró (1958 - não construído), realizado em parceria com Kubota, marca o início de sua trajetória pautada por uma arquitetura que se estabelece a partir experiência do usuário. Nesta ocasião, o arquiteto subverte a organização tradicional do programa de hotel que se estabelecia em primazia às imposições de ordem comercial em detrimento da experiência dos turistas.
$52 \uparrow$ Sede do Clube Campineiro Fonte: (PENTEADO, 1998, p. 22)

$53 \uparrow$ Estação de Tratamento de Água de São Bernardo do Campo Fonte: (PENTEADO, 1998, p. 21).
$54 \uparrow$ Estação de Tratamento de Água Campinas II Fonte: (PENTEADO, 1998, p. 22). 

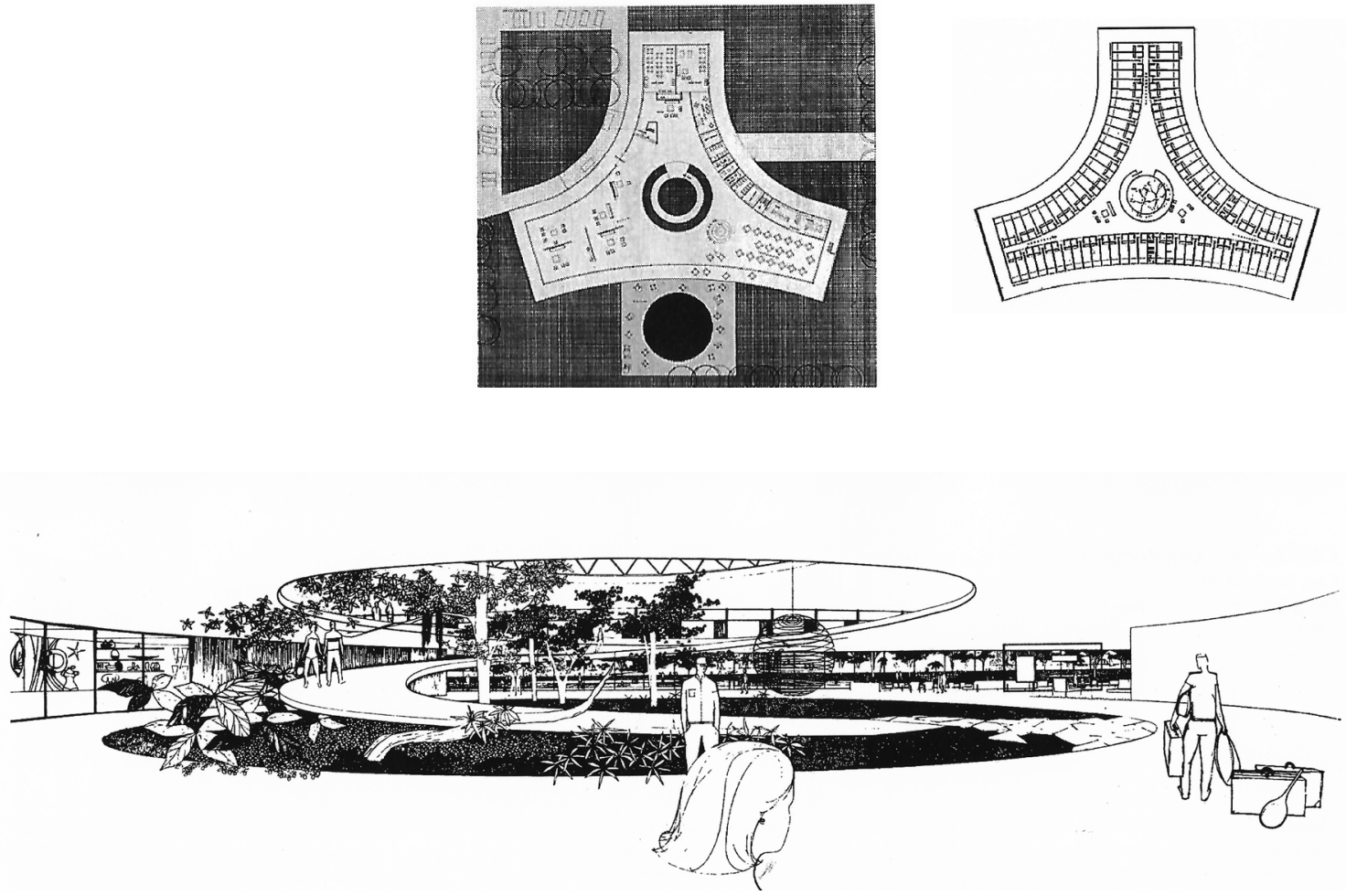

Em depoimento a Giroto, Penteado afirmou:

Por exemplo, um dos primeiros projetos que fiz foi um hotel em Cabo Frio. Eu fui a Cabo Frio e havia lá um hotel com uma plaqueta 'Proibido entrar com traje de banho'. Eu uma vez, conhecendo muito pouco como eu conhecia, estive uma vez no Copacabana Palace, e como hóspede para se chegar à praia se descia um elevador de serviço, passava pela cozinha para ir para a piscina e para a praia. Só que, é claro, você pode cruzar lá com um sujeito de fraque, cartola. Eu fiz a proposta para o hotel sem elevador e sem corredor. Por quê? Se você passa 10 ou 15 dias para encontrar a paisagem, se você cortar essa ligação, entre o seu quarto com um corredor escuro, corta o teu momento. (GIROTO, 2013, p. 451-452)

O hotel, encomendado pela Secretaria de Turismo do Estado da Guanabara, procura estabelecer uma relação íntima entre a natureza e o edifício. A partir de uma planta triangular, o programa ocupado pelas áreas administrativas é distribuído em uma porção do perímetro do térreo, enquanto uma grande área desimpedida organiza em seus vértices a rotina dos seus usuários. $\mathrm{O}$ acesso aos quartos, no pavimento superior, se dá por meio de uma rampa em espiral implantada no centro do projeto sobre o jardim projetado pela arquiteta-paisagista Rosa Kliass (1932).

Para Penteado, a arquitetura na década de 1960 se definiu a partir de alguns projetos de Vilanova Artigas, nos quais o arquiteto conseguiu realizar um admirável trabalho de síntese entre a arte de projetar e as possibilidades técnicas construtivas disponíveis. A modernidade dos resultados que alcançou era de tal forma surpreendente, que justificou o numeroso grupo que o acompanhou nas décadas seguintes. $\mathrm{E}$ acrescenta:
$55 \uparrow$ PerspectivasHotel Praia do Peró Fonte: (PENTEADO, 1998, p. 155).
$56 \uparrow$ PlantasHotel Praia do Peró Fonte: (PENTEADO, 1998, p. 155). 
Mesmo nessa renovação ocorrida em São Paulo, deve-se considerar a influência da arquitetura que estava sendo proposta no Rio de Janeiro - que se reforçou quando Oscar Niemeyer foi convidado para dirigir o projeto dos prédios para as festas do IV Centenário da Cidade de São Paulo, no parque do Ibirapuera, em 1954. Logo em seguida, com o início da construção de Brasília, a arquitetura e o urbanismo ganharam pela primeira vez uma posição de extraordinária evidência, até mesmo no nível da discussão popular, com espaço garantido na imprensa diária. (PENTEADO, 1983, p. 14).

Na virada da década de 1950 para 1960, Penteado venceu o concurso para a Sociedade Harmonia de Tênis (não construído) em 1958, com José Maria Gandolfi e Luiz Forte Netto. Este projeto pode ser considerado uma de suas obras sínteses destas referências citadas. Assim como a Casa Mário Taques Bittencourt (1959) de Artigas, a cobertura das quadras de tênis em concreto protendido se desdobra em pilares triangulares. $\mathrm{O}$ volume suspenso apoiado em pilotis do edifício-sede contém evidentes referências à escola corbusiana carioca.

Entre 1959 e 1962 Penteado projetou cinco obras para o Plano de Ação do Governo Carvalho Pinto - PAGE. Deste conjunto, o Fórum de Araras (1959), em parceria com José Carlos Ribeiro de Almeida, pode ser considerado a obra mais relevante. Para entender o mecanismo de funcionamento do programa, o arquiteto visitou alguns fóruns no interior de São Paulo e verificou que havia uma fórmula que organizava a arquitetura daqueles edifícios. As construções invariavelmente remetiam à linguagem greco-romana, com fachadas imponentes e alturas duplas de seus pés-direitos, conforme o arquiteto relatou à Giroto:

Só que o fórum é de um jeito que, como no caso de Araras que tinha então 30 mil habitantes, era tipicamente de gente que trabalhava na terra; o cara chegava lá e já entrava com medo. Então eu fiz um fórum que não tem porta, eu fiz uma pracinha de sombra onde o sujeito espera. Mas isso também foi típico: por que o sujeito tem que ser amedrontado? (...) Porque o cara já sabia que ia perder, entendeu? A justiça era do coronel, o advogado era do coronel. (...) Fórum pequeno, mas era para reduzir aquele peso daquela justiça, estranho, e abrir ao encontro. E porque que não pode ser um espaço que o sujeito pode entrar.

(GIROTO, 2013, p. 452)

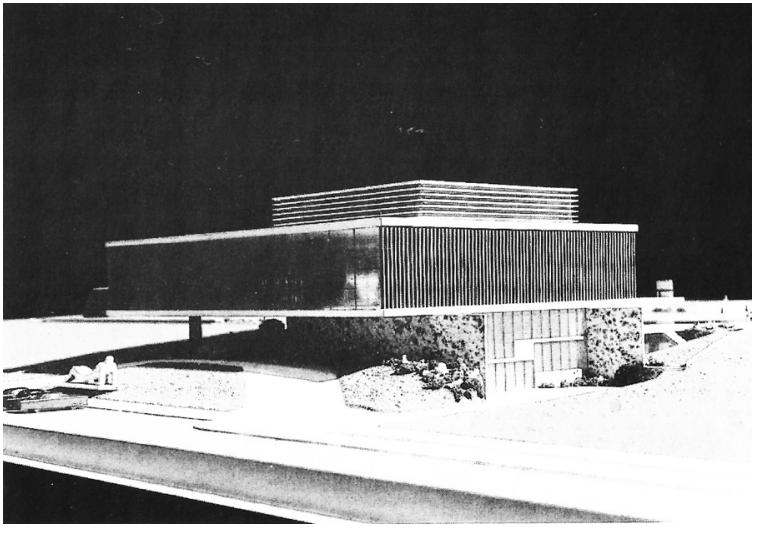

Subvertendo a estrutura fortemente hierárquica característica dos Fóruns, Penteado projetou um edifício convidativo a todos os cidadãos. Em lugar do saguão de pé-direito duplo, foi proposta uma praça coberta onde as pessoas pudessem sentar e conversar.

Com especial semelhança aos projetos dos Ginásios de Artigas, a cobertura única abriga, além da praça com espelho d'água, o programa de uso restrito que é distribuído em dois blocos destinados ao auditório para 200 lugares, também utilizado como uma pequena sala de música, cinema e teatro; e outro para cartórios, setores administrativos e de serviços. Ao fundo da praça uma caixa de escada cilíndrica organiza e intermedia o acesso às repartições.

Além do Fórum de Araras, de Fábio Penteado, foram construídos edifícios com a mesma finalidade em Avaré (por Paulo Mendes da Rocha), Itapira (Joaquim Guedes), Orlândia (Jorge Wilheim), Promissão (Vilanova Artigas), São José dos Campos (Paulo Sérgio Souza Silva) e Socorro (David Libeskind). Camargo (2019) revela a importância do projeto de Penteado: 
A proposta de Fábio Penteado para o Fórum de Araras, em 1960, é a mais paradigmática das mudanças pretendidas. A imponência e monumentalidade características dessa tipologia, sob a vigência do ecletismo, foram substituídas, nesses projetos, pela sociabilidade e convivência. De monumento urbano, o fórum se converteu em uma praça pública: os suntuosos saguões de entrada, geralmente em materiais nobres, foram trocados por amplas áreas de estar com espelho d'água, bancos de jardim, introduzindo um novo caráter ao espaço da justiça, não apenas como o símbolo da retidão e do julgamento, mas, sobretudo, da igualdade e do direito. (CAMARGO, 2019, p. 11)

Sobre este período, em que a vanguarda formada pelo seu grupo inicia a uma produção massiva com indícios de uma Escola Paulista, Penteado afirma:

Certamente o que se convencionou chamar de "Escola Paulista" nunca representou o pensamento da maioria dos arquitetos da cidade, mas não há dúvida que influenciou - bem ou mal - a formação de várias gerações de profissionais, de 1960 em diante. Ela se definiu, de fato, a partir de alguns projetos de Vilanova Artigas, no início dessa década, nos quais ele conseguiu realizar um admirável trabalho de síntese, juntando, como ele dizia, a arte de projetar com as possibilidades técnicas construtivas disponíveis. (PENTEADO, 1983, p. 14)

\section{E conclui:}

Os arquitetos paulistas, apesar de não terem sido chamados a participar dos projetos da nova capital, se beneficiaram muito daquele momento de abertura e tiveram seu campo de atuação ampliado de forma excepcional. Surgiram, de uma hora para outra, centenas de novos projetos; pode-se dizer que foi então que apareceram, na arquitetura paulista, os primeiros indícios de características próprias. (...) Não se pode negar a influência de alguns notáveis arquitetos cariocas, como os irmãos Roberto, Sérgio Bernardes, Jorge Moreira e fundamentalmente, as obras de Affonso Reidy, como a escola Brasil-Paraguay, em Assunção, e o Museu de Arte Moderna do Rio - ambas do início da década de 50 para a arquitetura de São Paulo. Houve como um 'encontro de ideias' entre essas obras e os trabalhos pioneiros de Artigas, influenciando decisivamente a chamada 'Escola Paulista'. (...) Eu tenho o Niemeyer como o arquiteto mais brilhante, mas - para mim - foi o Affonso Eduardo Reidy quem deu, no momento decisivo da renovação, a contribuição mais respeitável para o desenvolvimento da arquitetura brasileira atual. (PENTEADO, 1983, p. 14)
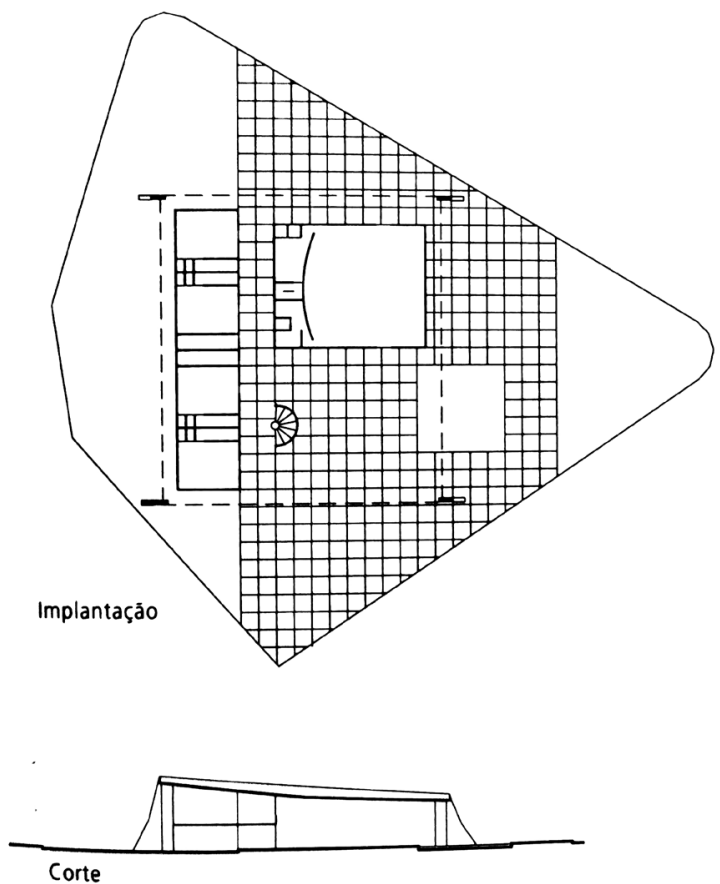

Corte

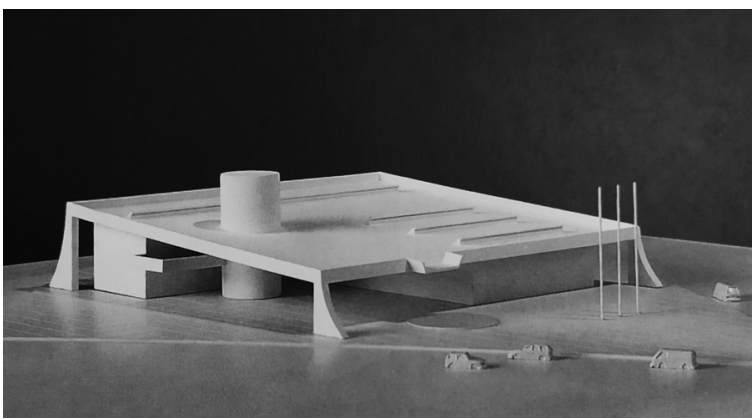



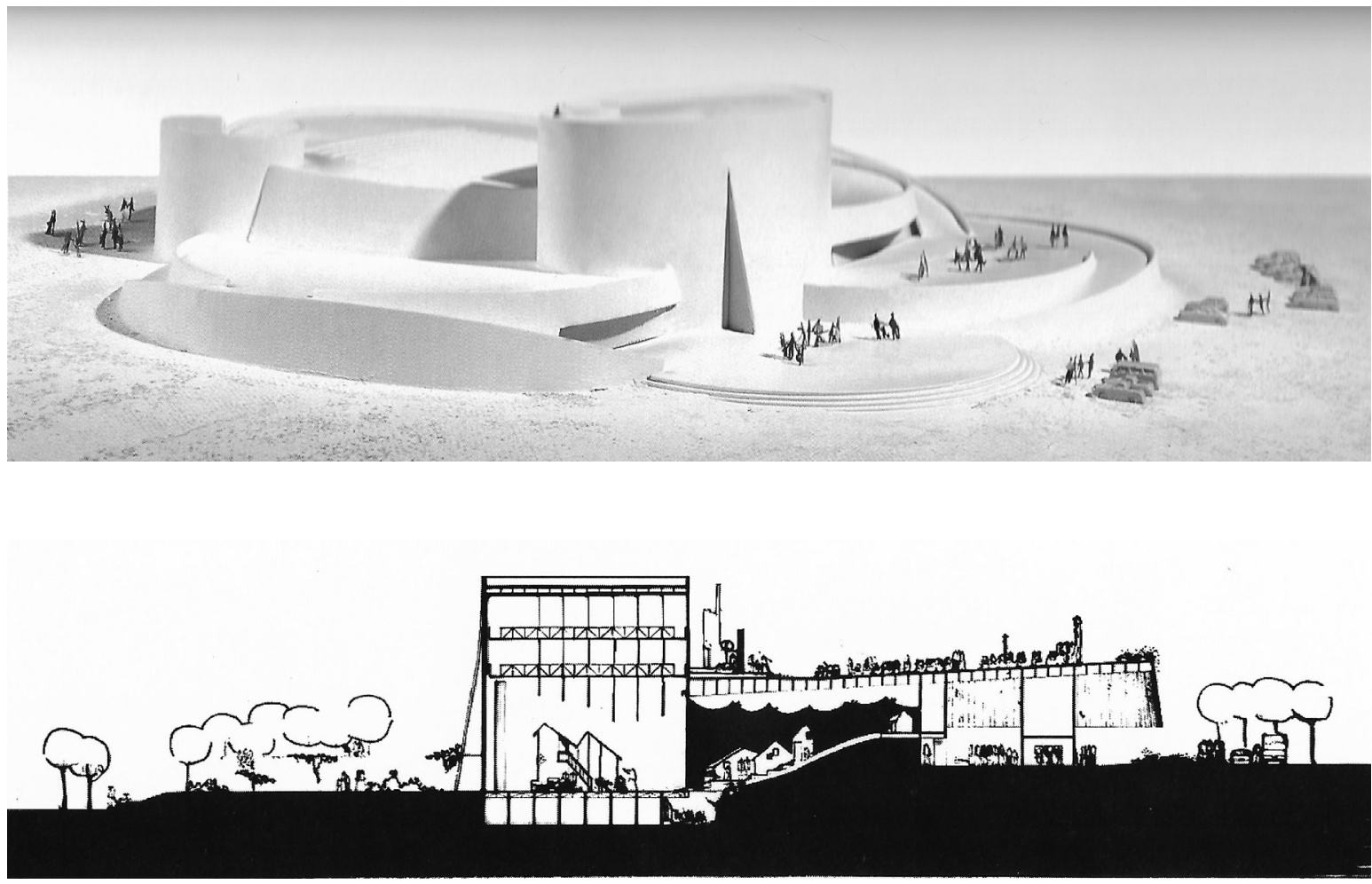

Para o Teatro Municipal de Piracicaba (não construído), projetado em 1960 com José Ribeiro, Penteado propôs um dos edifícios que considerava mais bonito. A ser implantado em uma praça existente, Penteado subverte o bloco construído convencional e propõe uma arquitetura que "é teatro e é praça" a partir de um edifício que reconstrói a topografia natural em patamares de uso irrestrito da população de onde poderiam usufruir dos espaços externos 24 horas por dia e avistar o rio Piracicaba.

A convite do empresário Adalberto Camargo (1923-2008), Penteado projetou com José Ribeiro e Roberto Loeb o Conjunto Habitacional do Limão (19601962) em São Paulo, com 1400 unidades e a Cidade dos Doqueiros (1962-1963) em Santos, com 4500 unidades.

O projeto do Bairro do Limão foi projetado num amplo terreno íngreme, como uma "escada de gigantes"; em cada patamar foi implantada uma superquadra com habitações, núcleos de comércio e lazer.

Para a Cidade dos Doqueiros, localizada em uma antiga pedreira, os arquitetos propõem a escavação do paredão de rochas que faz surgir um espelho d'agua para recolher as águas das chuvas e nascentes do lugar. A partir deste ponto uma implantação radial organiza em leque as superquadras, a praça de convivência e áreas de lazer e comércio. As fachadas do edifício eram painéis cromáticos idealizados pelo artista Antônio Maluf (1926-2005).

Em parceria com os engenheiros Falcão Bauer (1921-1996) e o russo Waldemar Tietz (1889-1978), a equipe realizou uma importante pesquisa no campo da produção industrial e da construção civil para o emprego de peças pré-moldadas e incorporação de mobiliário e equipamentos das unidades. Estes projetos foram cancelados por dificuldade de viabilização econômica mas foram fundamentais para a viabilização do Conjunto Habitacional Zezinho Magalhães Prado - Parque CECAP Guarulhos (1967), projetado em parceria com Vilanova Artigas, Paulo Mendes da Rocha, Maria Giselda Visconti, Geraldo Vespaziano Puntoni, Ruy Gama, Arnaldo Martino e Renato Nunes.

$60 \uparrow$ Maquete do Teatro Municipal de Piracicaba Fonte: (PENTEADO, 1998, p. 92).

$61 \uparrow$ Corte do Teatro Municipal de Piracicaba Fonte: (PENTEADO, 1998, p. 92). 
Em 1962, Penteado, Ubirajara Giglioli, Tito Lívio Frascino, Vasco de Mello e José Ribeiro conquistaram o 2 o lugar no concurso para o Monumento de Playa Girón (não construído). Para comemorar a vitória dos cubanos frente à invasão americana na Baia dos Porcos, o concurso, organizado pela União Internacional de Arquitetos - UIA, solicitava um monumento, uma praça para 30 mil pessoas e um museu para guardar as armas conquistadas do inimigo. A equipe de Penteado produz um projeto com grande poder de síntese e subverte as solicitações do edital. Contrário à ideia de um museu de guerra, os arquitetos propõem o enterramento das armas na fundação de um gigantesco monumento. A proposta elaborada em apenas quatro dias, foi representada por uma curiosa maquete de palitos de sorvete e chiclete fotografada pelo cenógrafo italiano Aldo Calvo (1906-1991), que residia no Brasil. O memorial elaborado por Penteado possuía nove laudas, e como não havia tempo suficiente para traduzi-las nos idiomas solicitados pela UIA (inglês, russo, francês e espanhol) coube ao arquiteto reduzi-lo a três frases:

\author{
De longe é paisagem. \\ De perto é monumento. \\ A praça é o povo. (PENTEADO, 1998, p. 78)
}

A premiação, que deveria ocorrer em um pavilhão de Havana, ocupou a extensão de $6 \mathrm{~km}$ das ruas e praças da cidade. O projeto de Penteado recebeu o elogio de Fidel Castro e um belo texto de um crítico da revista japonesa Kokusai Kentiku - International Review of Architecture (edição de junho de 1967) que o descreveu como "o grito de vitória de uma multidão, repentinamente congelado no espaço" (PENTEADO, 1998, p. 78). No entanto, segundo o arquiteto, no contexto de polarização política às vésperas do período de ditadura militar, este projeto fez com que surgissem muitos problemas:

(...) pelo fato de ter sido feito para Cuba, e até mesmo não só problemas com o governo, mas houve uma curiosa exigência, do grupo de cultura com o qual eu mais convivia, de me colocar como um herói, por conta de uma ideologia. Eu não concordei em nenhuma hipótese, por mais simpática que essa ideologia me fosse, e como argumento disse: 'olha, neste momento estou detestando muito o Papa e o Vaticano, mas se houvesse um concurso eu poderia também concorrer e não é por isso que eu iria apoiar o Vaticano'. Essa minha atitude foi muito
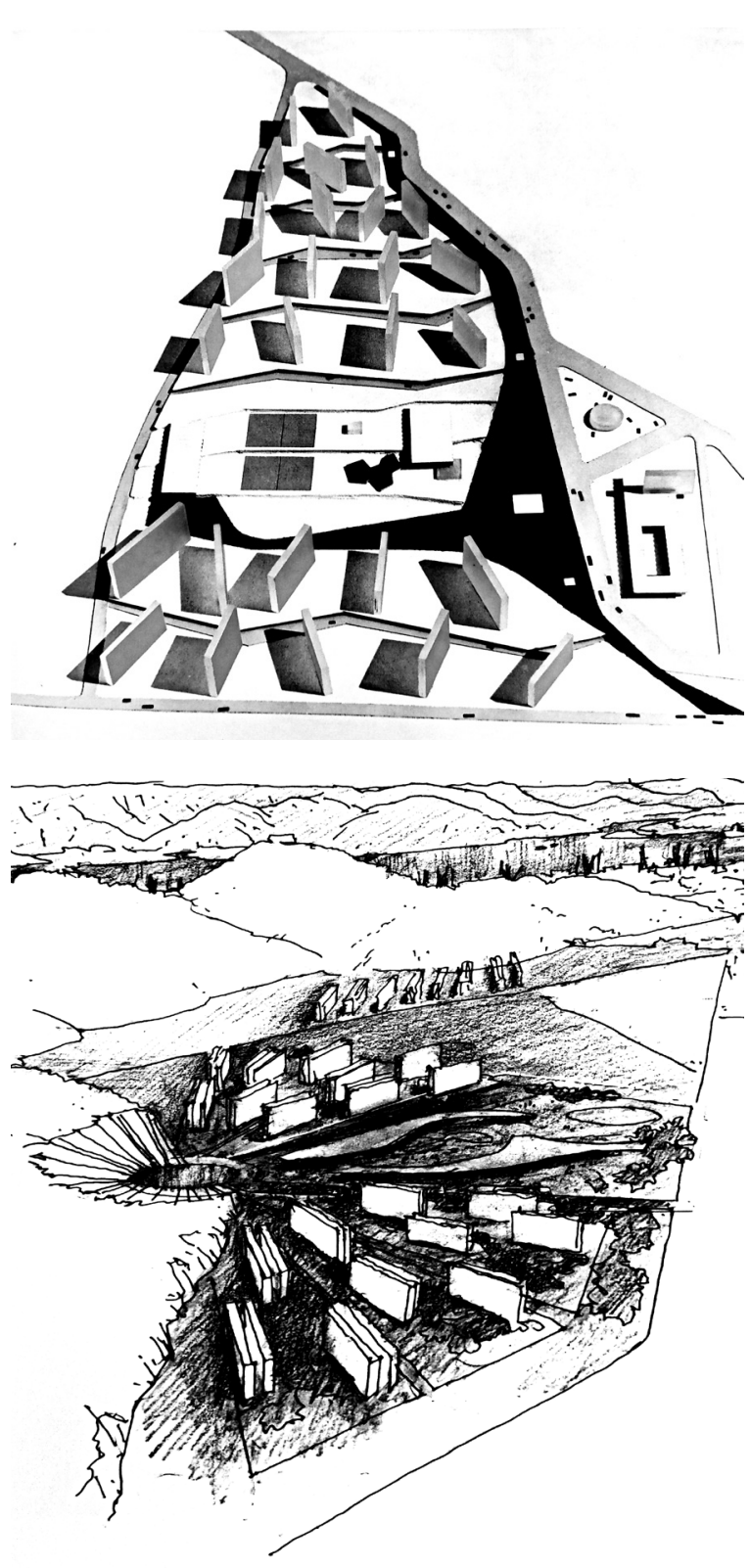

$62 \uparrow$ Maquete do projeto Bairro do Limão Fonte: (PENTEADO, 1998, p. 133)

$63 \uparrow$ Pespectiva para Cidade dos Doqueiros Fonte: (PENTEADO, 1998, p. 136). 


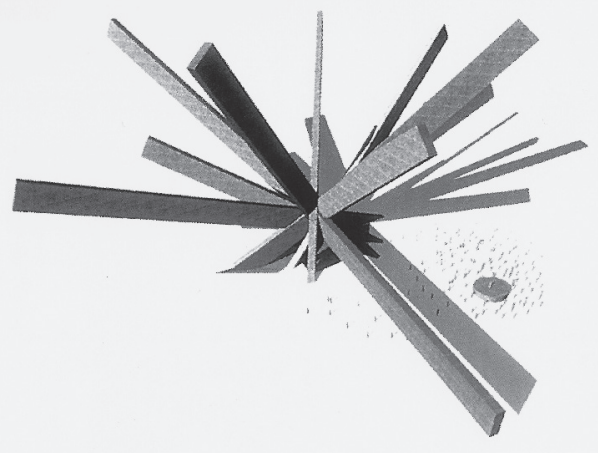

mal interpretada na época. (PENTEADO, 1983, p. 23)

Em 1964, no período em que foi realizado o Concurso para a Sede da Sociedade Harmonia de Tênis, Penteado já estava em uma fase madura de sua produção. Após desenvolver diversos projetos, muitos deles construídos, e participar da experiência proporcionada pelas encomendas do PAGE, sua arquitetura pouco se parecia com aquela proposta para o concurso de 1958. No entanto, o que pode conferir uma unidade entre estes períodos é a incessantemente busca por uma arquitetura libertária e humanista.

Embora não tenha se filiado ao Partido Comunista, em 1964 foi afastado do cargo que exercia como professor na Faculdade de Arquitetura do Mackenzie e reconhecidamente viabilizou o exílio de Artigas e de outros colegas. Segundo Adriana Penteado, filha do arquiteto, declara que seu pai era visto como um industrial no IAB e como um comunista no Clube Harmonia. Talvez seja esta uma das razões para o arquiteto se manter à margem das publicações e estudos dedicados à vanguarda arquitetônica desse período.

Em sua trajetória profissional, Penteado desempenhou diversas funções, das quais podemos destacar: a presidência do IAB Nacional (1968); Membro do Comitê Executivo e do Conselho Superior da UIA (1969); Diretor da Revista Projeto (1972-1986); e Membro Honorário do American Institute of Architects (1973). Entre 1949 e 2007, Penteado elaborou aproximadamente cem projetos de arquitetura. Faleceu aos 82 anos, em 26 de junho de 2011.

Duas publicações foram dedicadas exclusivamente à sua obra: o livro "Fábio Penteado - Ensaios de Arquitetura" de 2002; e a tese de Doutorado, fruto de uma ampla pesquisa, desenvolvida por Ivo Giroto pela Universidade Politécnica da Catalunha, intitulada "A praça é o povo. Intenção, projeto e multidão na arquitetura de Fábio Moura Penteado" (2013).

No ano de 2018, por iniciativa de Adriana Penteado, foi fundado o Arquivo Fábio Penteado, com o objetivo de catalogar, restaurar e promover a pesquisa do acervo do arquiteto. Ao todo foram identificados 10.603 itens, subdivididos entre Projetos de Arquitetura (desenhos, cadernos de apresentação, slides negativos e ampliações fotográficas relativos aos seus projetos) e Documentação Paralela, constituída por documentos referentes à atuação de Fábio Penteado em outras frentes. Em acordo firmado com a Casa de Arquitectura, localizada em Portugal, parte do acervo foi doado para a instituição. Em 2019 foi realizada a mostra: Irradiações - Fábio Penteado, em comemoração dos 90 anos do seu nascimento.

\section{NOTAS}

1 Disponível em: http://smul.prefeitura.sp.gov.br/historico_ demografico/img/mapas/1913.jpg. Acesso em: 01 de Dez. 2019.

2 Disponível em: https://1.bp.blogspot.com/aPB_qyzh3CM/WWSJHXhO9OI/AAAAAAAAEEI/ TukT9nlh-EgufnsMCwVr7qUunz6qBpanwCLcBGAs/ s1600/1300_Letchworth\%2Boriginal\%2Bplan. jpg. Acesso em: 01 de Dez. 2019.

3 O Estádio Jardim América foi utilizado para a realização do Campeonato Paulista até a profissionalização do esporte em 1929. Acabou sendo demolido em 1950. 

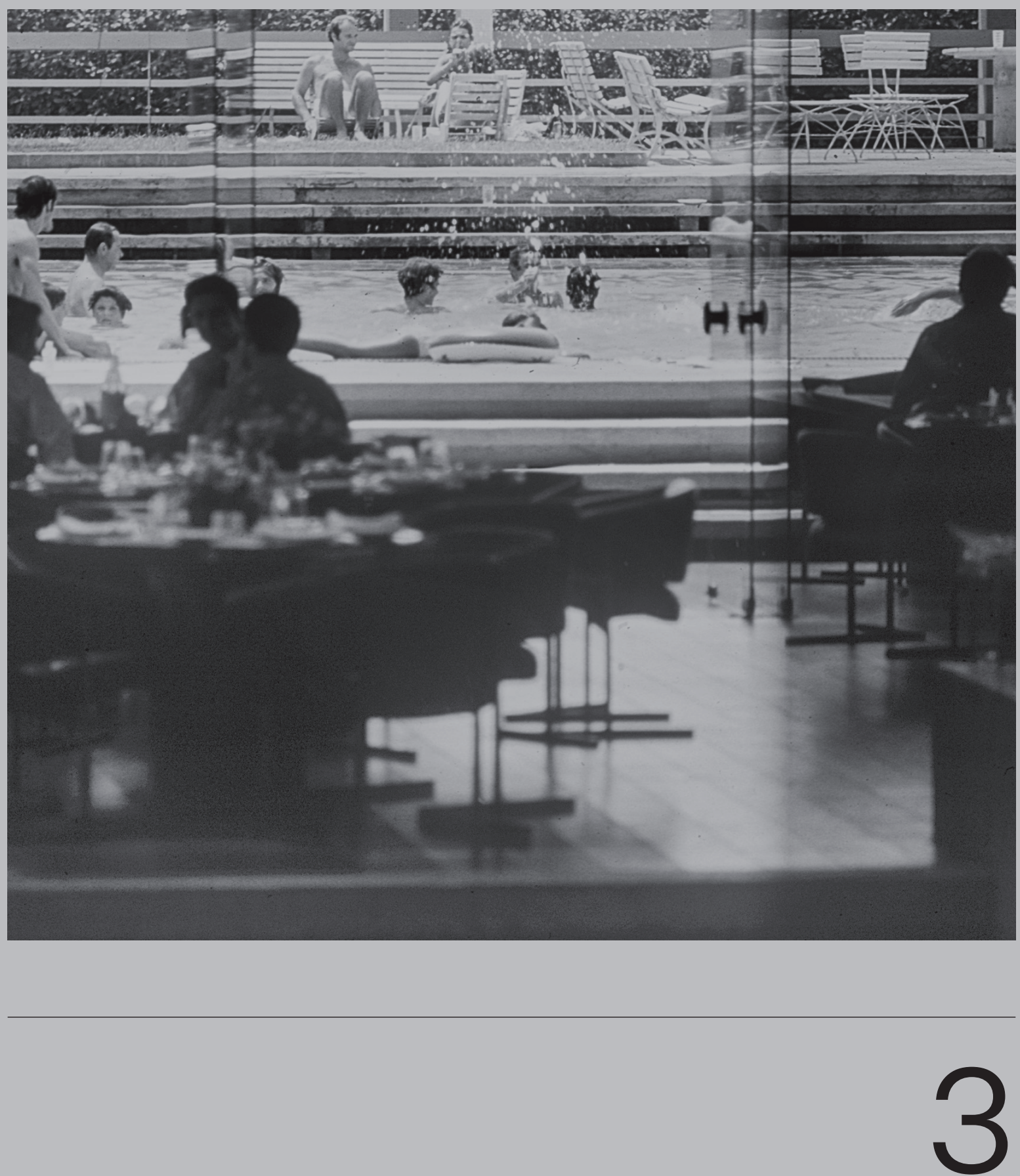


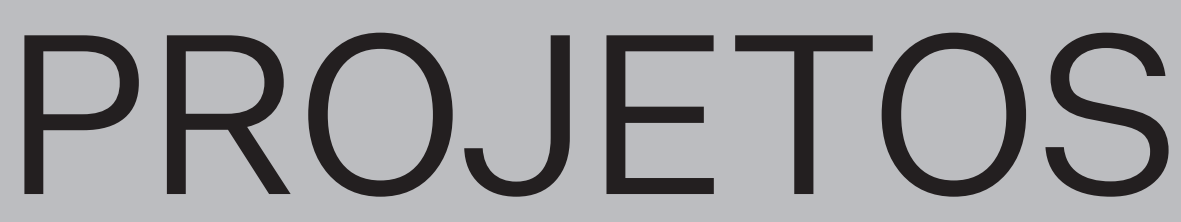




\section{CONCURSO DE 1958}

Para adequar suas instalações ao aumento de público, em 1958 o Clube Harmonia convocou o Instituto de Arquitetos do Brasil para promover um concurso nacional de arquitetura. Setenta e dois profissionais renomados foram convidados e 28 apresentaram trabalhos. O programa solicitava uma sede com salões de estar, jogos, restaurante, boite e um departamento esportivo, incluindo duas quadras de tênis cobertas.

Um dos sócios do clube, o arquiteto Fábio Penteado, com apenas cinco anos de formado, venceu o concurso em parceria com Luís Forte Neto e José Maria Gandolfi. Participaram da equipe os engenheiros civis Oswaldo Moura Abreu, Nelson de Barros Camargo e Waldemar Tietz, além de Francis Laugery, responsável pelo projeto das cozinhas.

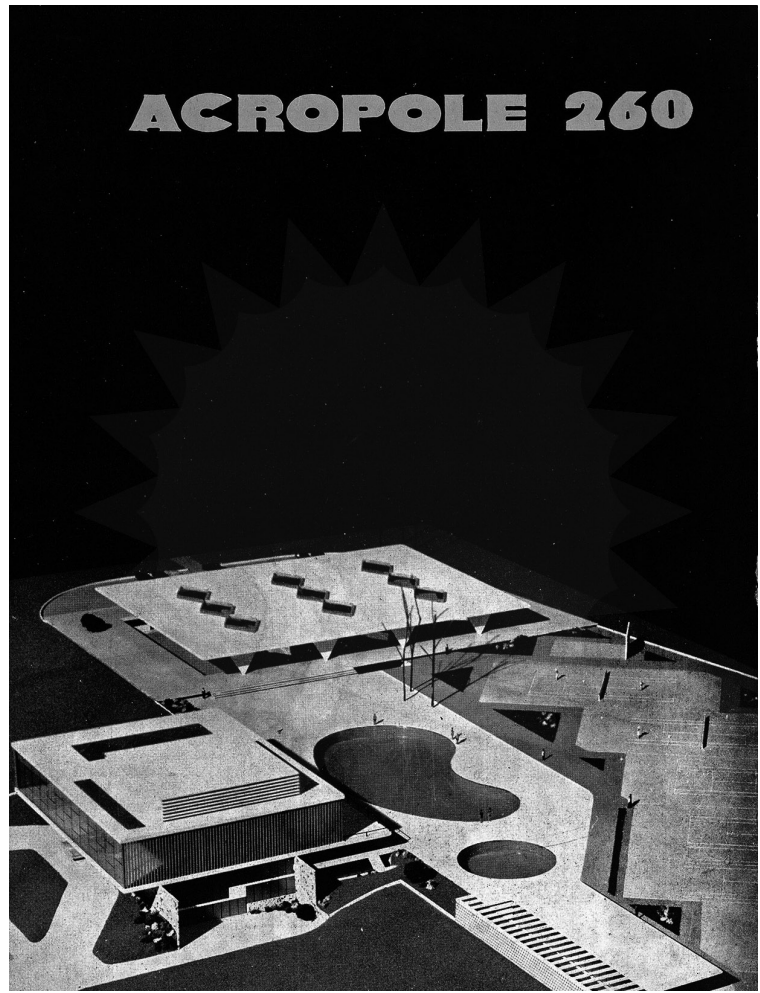

A Revista Acrópole n.o 260, de maio de 1960, publicou o projeto em sua matéria de capa. Segundo a reportagem, a principal característica do projeto vencedor foi a obtenção de grandes áreas livres ajardinadas, dando ao Clube um espírito adequado às suas finalidades.

O conjunto de desenhos definitivos entregue pela equipe de Fábio Penteado formavam nove pranchas e organizava-se por meio de um memorial explicativo (folha 1); planta de situação (folha 2); perspectivas (folhas 3 e 4); planta do edifício-sede (folha 5); cortes do edifício-sede (folha 6); elevações (folha 7); plantas do ginásio (folha 8); cortes do ginásio e desenhos da sede provisória (folha 9).

O projeto da equipe de Penteado possuía $6.375 \mathrm{~m} 2$ de área construída e previa o faseamento de suas obras em três etapas: inicialmente seria construída uma pequena sede provisória, que mais tarde seria convertida em pavilhão infantil; na segunda fase haveria a demolição da antiga sede, com frente para a rua Canadá, para a construção do novo edifício que ocuparia esta função. Em contraposição ao edifício-monumento que havia em seu lugar, o térreo do novo edifício era constituído por uma praça de acesso coberta e desimpedida, sobre pilotis. O hall estava encerrado em uma caixa de vidro curva, ao lado da secretaria e diretoria, a partir da qual se acessava às demais dependências sociais internas, em percurso ascendente, por uma ampla escada em leque. Os programas compartimentados eram distribuídos nos três níveis superiores. No subsolo estavam localizados os vestiário para sócios, interligados às piscinas, e áreas de apoio e vestiários para funcionários, acessados diretamente por um pátio lateral de serviços. No primeiro pavimento estavam o living (salão de festas), salas de leitura e de televisão, restaurante com terraço e bar. $O$ segundo pavimento era dedicado às áreas de jogos e o terceiro à boite; na terceira fase seria demolido o estádio de tênis para a construção de uma grande cobertura plana estruturada por uma laje nervurada de concreto protendido, que vencia um vão de $42 \mathrm{~m}$, apoiada em pilares em V. Esta estrutura abrigava o acesso coberto pela rua Argentina, uma quadra de tênis e uma quadra poliesportiva, semi-enterradas para adequar-se ao gabarito de altura exigido pela Cia. City, além uma sala de cinema e vestiários.

O projeto possui referências diretas à escola carioca, de matriz corbusiana, nos pilotis que liberam o

$65 \uparrow$ Capa da Revista Acrópole, n.o 260 - Estudo para o Concurso de Anteprojetos da Sociedade Harmonia de Tênis, São Paulo, 1958. Fonte: Revista Acrópole, n.o 260, maio de 1960. 


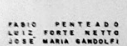

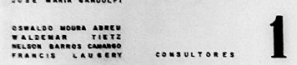

Ginaso e Ovato Coberta

Ginaso e Ovata Coberta

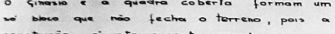

Datto $\infty$ bloco hì una pasragem que liga

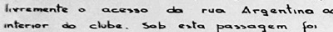

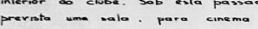

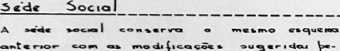

anterioer con - modificacóes sugerida

arilkào In|antil . Séde provisoria

o porithào infants devera abrigar, durante

as absas, a rede provisorio do clube a

construida. Pouts andente a mesma constie

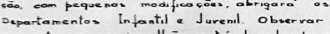

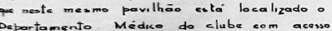

Departamento Médico do slub
independente. (ver follhe g)

Piscina

Aiscino
formas sentro de swas ponceses originais
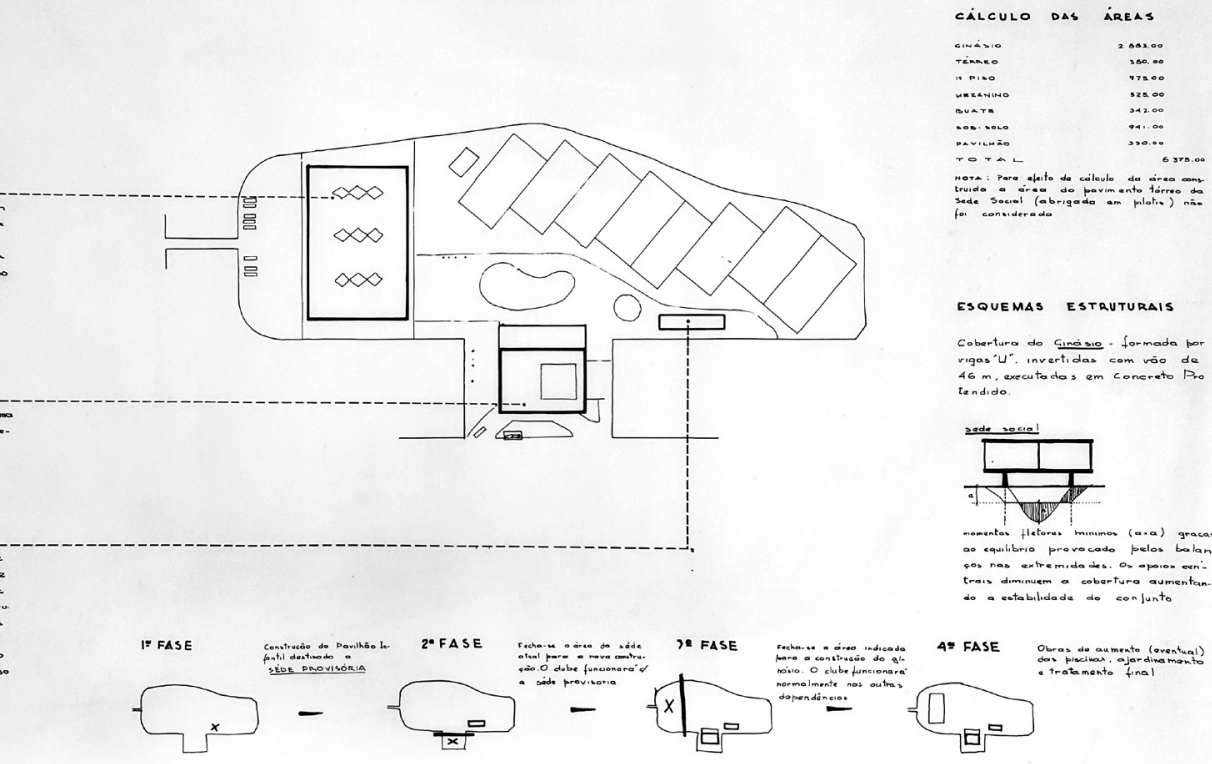

gemas estruturals

rgas "Ut, invertidas com vio de

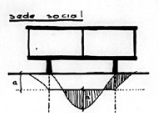

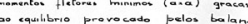

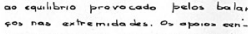
trais dimususer a cobertura aumentan

\section{$\mathbb{S} \mathbb{R} \mathbb{I} \mathbb{T}$ \\ ……................. 2}

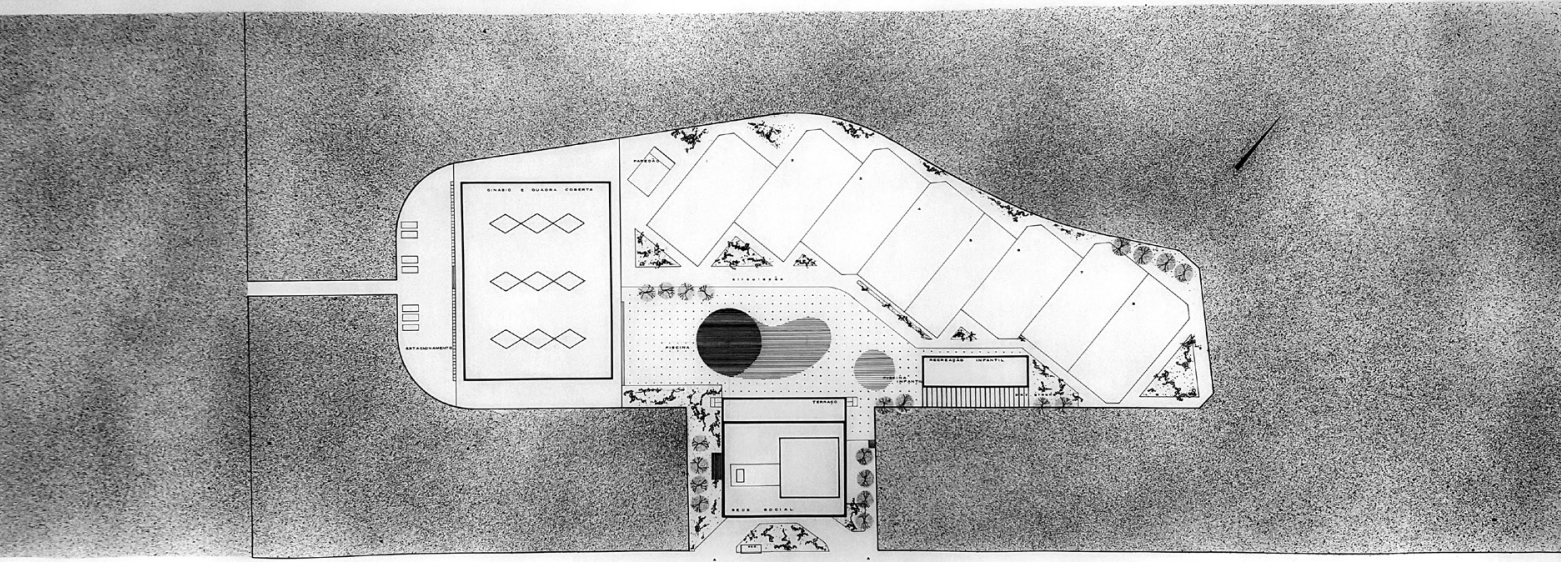

$66 \uparrow$ Folha 1, Memorial Explicativo - Estudo para o Concurso de Anteprojetos da Sociedade Harmonia de Tênis, São Paulo, 1958.

Fonte: Acervo do Arquivo Fábio Penteado.
$67 \uparrow$ Folha 2, Planta de Situação - Estudo para o Concurso de Anteprojetos da Sociedade Harmonia de Tênis, São Paulo, 1958.

Fonte: Acervo do Arquivo Fábio Penteado. 
$\mathbb{N} \mathbb{R} \mathbb{R}$

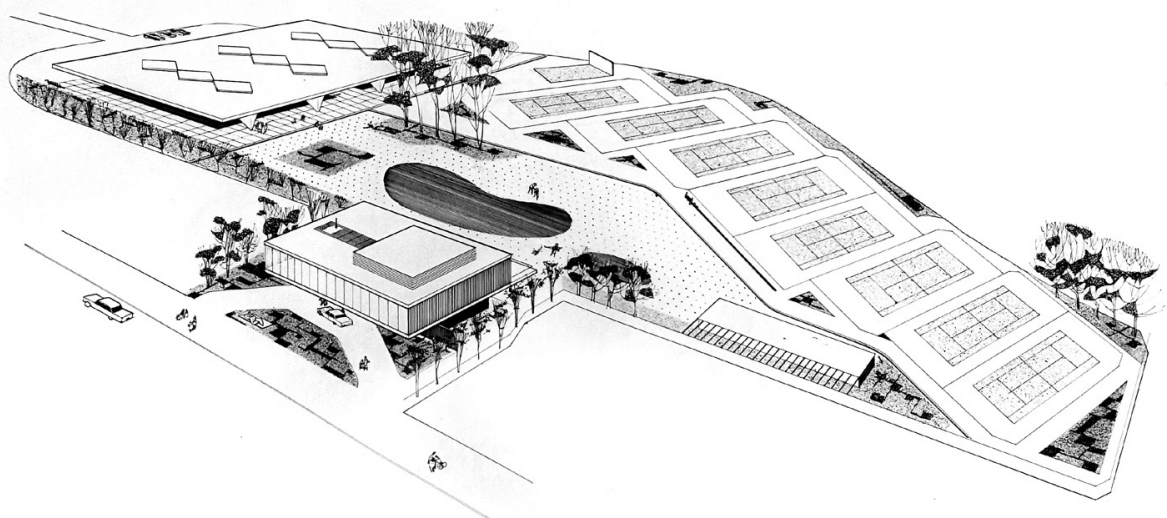

(1) II
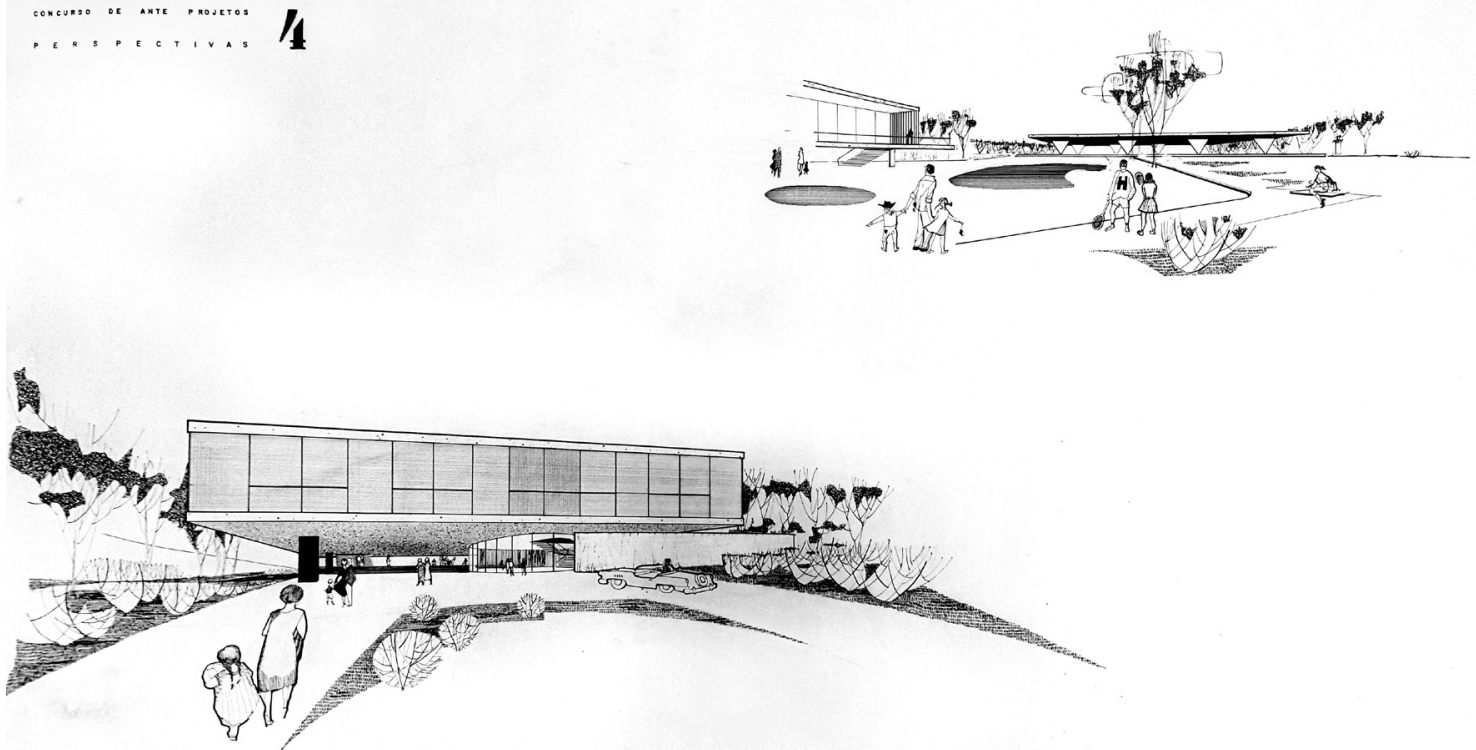

$68 \uparrow$ Folha 3, Perspectiva - Estudo para o Concurso de Anteprojetos da Sociedade Harmonia de Tênis, São Paulo, 1958. Fonte: Acervo do Arquivo Fábio Penteado.
$69 \uparrow$ Folha 4, Perspectivas - Estudo para o Concurso de Anteprojetos da Sociedade Harmonia de Tênis, São Paulo, 1958.

Fonte: Acervo do Arquivo Fábio Penteado. 


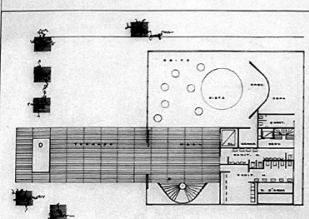

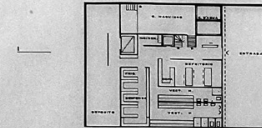

$\because=1 .+1$
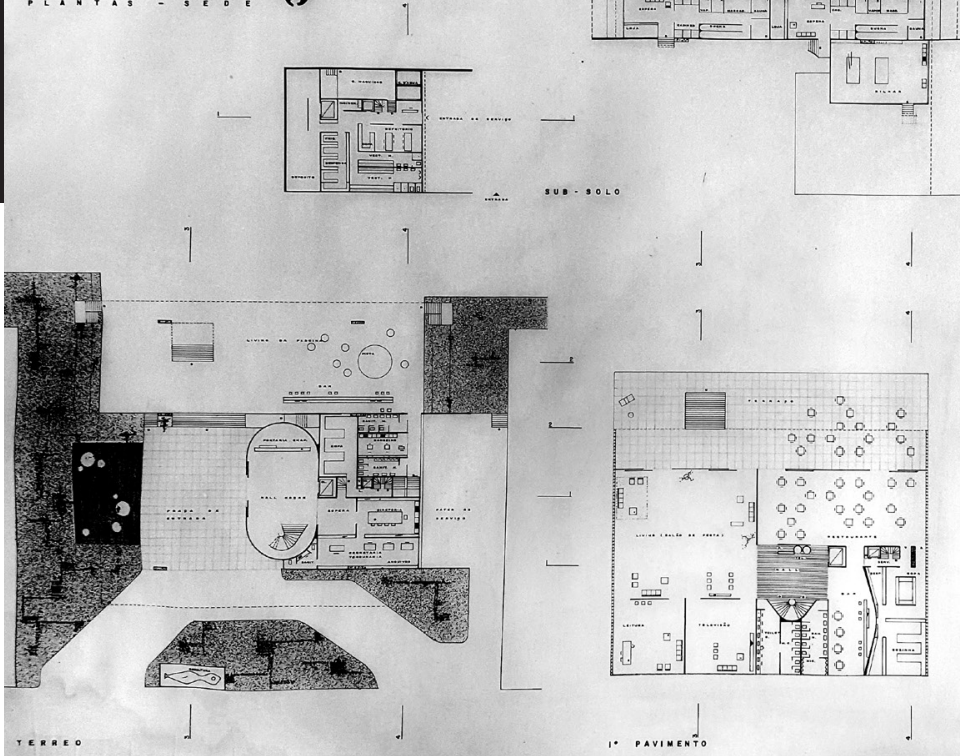

\section{(1) गI

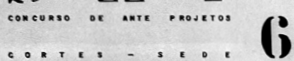
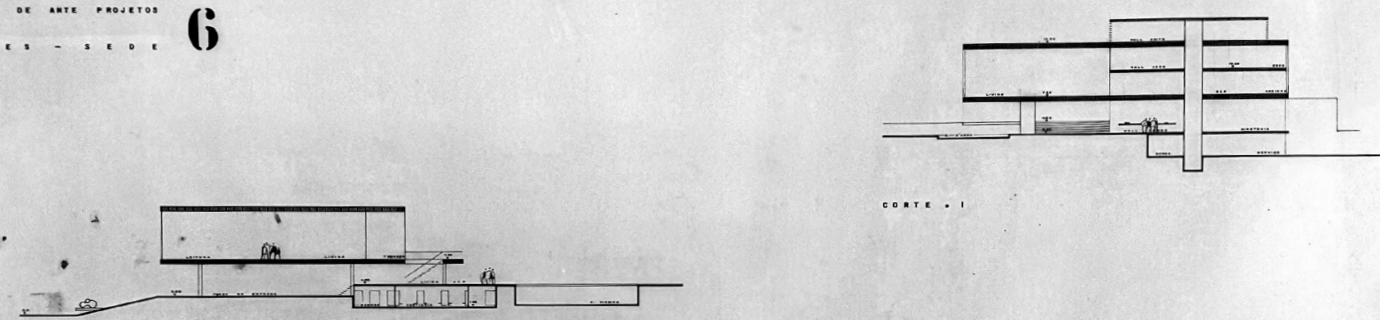

conse.
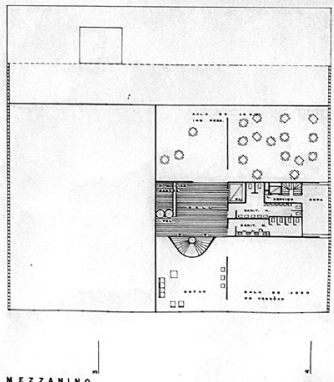

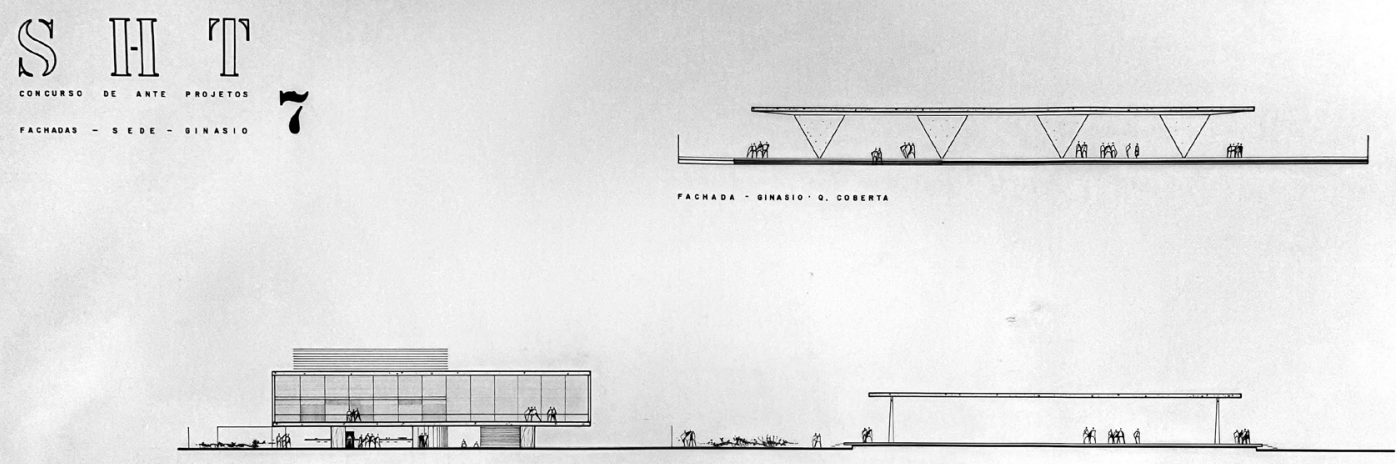
PACHADA InTERNA

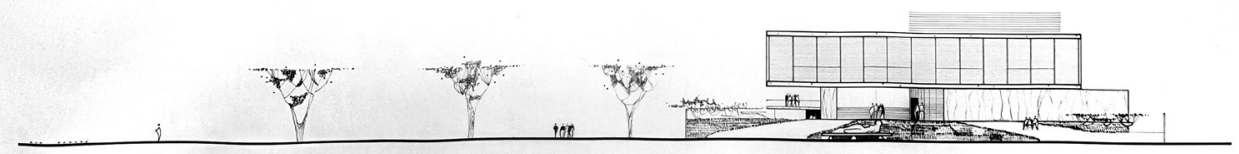

Eachade rua canade

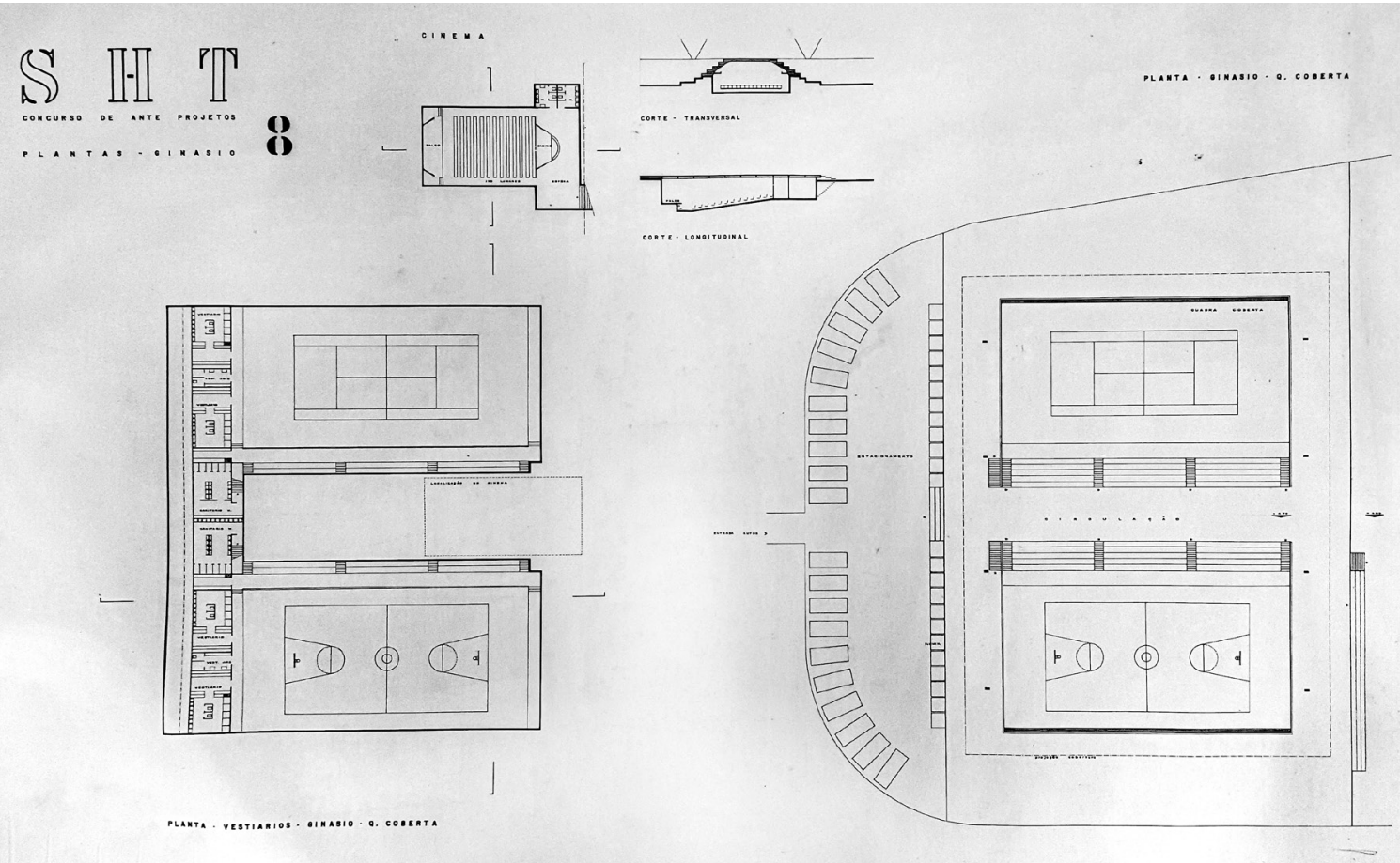

$72 \uparrow$ Folha 7, Elevações do Edifício-Sede - Estudo para o Concurso de Anteprojetos da Sociedade Harmonia de Tênis, São Paulo, 1958.

Fonte: Acervo do Arquivo Fábio Penteado.
$73 \uparrow$ Folha 8, Plantas do Ginásio - Estudo para o Concurso de Anteprojetos da Sociedade Harmonia de Tênis, São Paulo, 1958.

Fonte: Acervo do Arquivo Fábio Penteado. 
CORTE LONGTuQinal Ginasio. o. cosenta

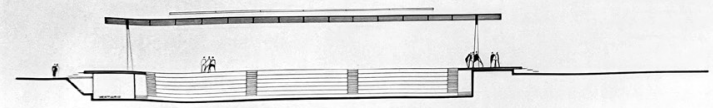

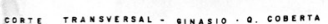
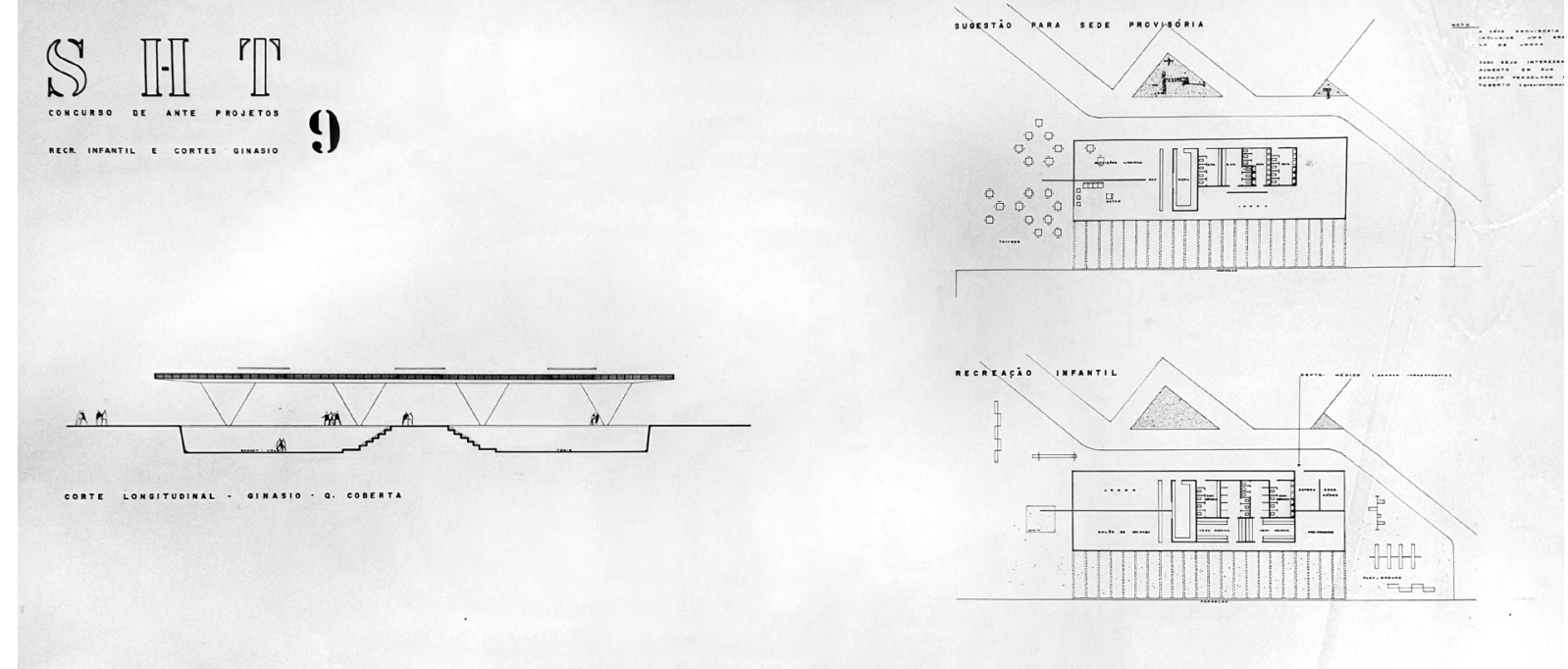

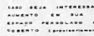
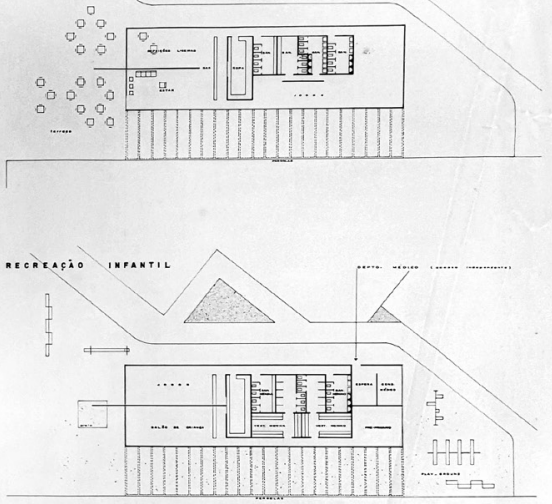

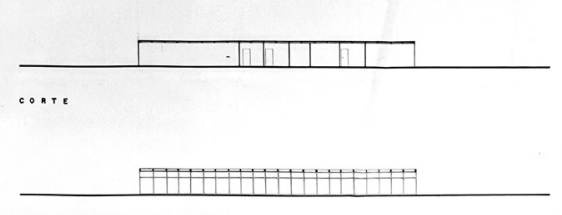

ELEYCSEO

$74 \uparrow$ Folha 9, Cortes do Ginásio e Desenhos da Sede Provisória - Estudo para o Concurso de Anteprojetos da Sociedade Harmonia de Tênis, São Paulo, 1958. Fonte: Acervo do Arquivo Fábio Penteado. 
térreo do edifício-sede e a sua escada escultural em leque encerrada na caixa de vidro. Os pilares em V que conformam os apoios da laje protendida, embora dispostos em placas, se assemelham aos utilizados nos projetos de Niemeyer. Após ser declarada vencedora, a proposta foi revisada pela equipe a pedido da comissão julgadora. Por falta de verbas, os projetos executivos e as obras não foram iniciados.

\section{CONCURSO DE 1964}

A Sociedade Harmonia de Tênis instituiu em 29 de outubro de 1964 um novo concurso para a escolha do anteprojeto e contratação do projeto definitivo de sua nova sede social, situada na rua Canadá, 658 , bairro do Jardim América em São Paulo.

O concurso foi organizado juntamente com o Instituto de Arquiteto do Brasil representado pelo arquiteto consultor, Júlio Neves, de acordo com o Regulamento Oficial para Concursos de Arquitetura, do IAB. Os concorrentes convidados foram os arquitetos Antônio Luiz de Anhaia Melo e o arquiteto Fábio Moura Penteado. O júri era composto pelos arquitetos Ícaro de Castro Mello, (1913-1986) Luiz Roberto de Carvalho Franco, (19262001) e Rubens Gouvêa Carneiro Vianna (1914-1987).

$\mathrm{O}$ anteprojeto deveria indicar a solução geral do problema com a definição do partido adotado, da concepção estrutural e das instalações em geral, possibilitando clara compreensão da obra a ser executada através de plantas, cortes e elevações em escala 1:100 e de memoriais explicativos nas próprias folhas de desenho. Não seriam permitidas variantes do projeto nem informações que identificassem seu autor. Os concorrentes deveriam fornecer, no mínimo, a perspectiva externa do conjunto vista da rua, perspectiva da entrada e perspectiva internas. Os desenhos e memoriais seriam apresentados em cópias heliográficas azuis do mesmo tamanho, fixados em superfície plana com dimensão máxima de $1,20 \mathrm{~m}$ x 1,20m. Os trabalhos deveriam ser entregues até às 17 horas do dia 30 de novembro de 1964.
O programa previa a possibilidade de realização da obra em duas fases, visto que a antiga sede não deveria ser demolida. Na primeira fase deveria ser proposta a construção em dois níveis, na frente da antiga sede. Na segunda fase seria prevista a demolição da antiga sede ampliando-se o segundo nível da primeira fase.

Para a primeira fase, deveria ser previsto o seguinte programa:

Acesso com portaria, chapelaria, PABX.

Secretaria para 6 funcionários, local para arquivos e serviços de addressograph e mimeógrafo.

Tesouraria para 4 funcionários, local para cofre, etc.

Contabilidade para 8 funcionários, local para arquivo, etc.

Departamento Pessoal para 2 funcionários, local para arquivo, etc.

Entrada de serviço para funcionários com portaria.

Sanitário para 20 funcionários administrativos, (ambos os sexos).

Sala de reuniões de Diretoria (aproximadamente 15 pessoas).

Sala de Gerência.

Sanitários funcionários.

Biblioteca - Salão de leitura.

Sala de televisão.

Sala de Jogo para bridge para 100 pessoas.

2 Saletas para carteado para 4 mesas de dez pessoas cada.

Sanitários sócios.

Para a segunda fase seria previsto:

Bar ( frequência atual até 50 pessoas). Restaurante (frequência atual até 200 refeições).

Salão de festas.

Copa de distribuição.

Copa.

Cozinha.

Despensa.

Cambusa.

Sorveteria, etc.

Sanitários. 
Os concorrentes poderiam sugerir alterações ao programa, fundamentando-as através do memorial descritivo.

A título informativo era esclarecido que em seu quadro societário o clube possuía 3500 sócios maiores e 2300 sócios menores de idade e que a diferença de nível entre a guia da rua Canadá e a borda da piscina era de $4,45 \mathrm{~m}$, posteriormente aferida no projeto executivo em $3,685 \mathrm{~m}$.

De acordo com a escritura do lote, foram feitas pela Cia. City as exigências dos seguintes parâmetros:

\author{
- recuos \\ lote de frente - frente $10 \mathrm{~m}$ - lateral 10m \\ lote de fundo - 5 metros em relação às divisas \\ - alturas permissíveis \\ lote de frente - 2 pavimentos acima do nível \\ superior de terreno e um pavimento \\ no nível inferior do terreno. \\ lote de fundo - 2 pavimentos com \\ altura máxima de $10 \mathrm{~m}$
}

O anteprojeto deveria ter área máxima aproximada de 2000m2, possibilitando uma previsão de custo inicial de $\mathrm{Cr} \$ 200$ milhões ( $\mathrm{R} \$ 5.826 .489,11$ corrigidos pelo IGPM-DI da FGV em dezembro de 2019), aproximadamente $\mathrm{R} \$ 2900,00 / \mathrm{m} 2 \mathrm{em}$ valores atuais. A remuneração seria paga em dinheiro pelo clube para o desenvolvimento do projeto executivo, de acordo com a minuta de contrato e ao segundo colocado caberia a importância de $\mathrm{Cr} \$ 2,8$ milhões ( $\mathrm{R} \$ 81.570,85$, corrigidos pelo IGPM-DI da FGV em dezembro de 2019) e ao IAB, como remuneração dos trabalhos de orientação e organização do concurso, do júri e do arquiteto consultor, a importância de $\mathrm{Cr}$ \$1,4 milhões ( $R$ \$ $40.785,42$ corrigidos pelo IGPM-DI da FGV em dezembro de 2019)

O anúncio do vencedor e o ato de encerramento do concurso seria realizado em 7 de dezembro de 1964.

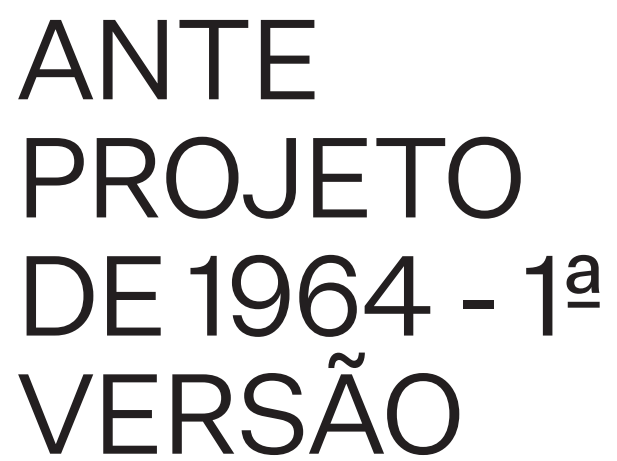

Fábio Penteado, em parceria com Alfredo Paesani e Teru Tamaki, entregaram a proposta para o anteprojeto de 1964, representada por um conjunto de 11 pranchas de $1,20 \mathrm{~m} \times 1,20 \mathrm{~m}$ distribuídas em plantas (folhas $1 \mathrm{a}$ 4); cortes (folha 5); elevações (folha 6); perspectiva vista da rua (folha 7); perspectiva da entrada (folha 8); perspectivas internas (folhas 9 e 10); e memorial explicativo (folha 11).

A proposta manteve algumas das intenções do projeto vencedor em 1958, tais quais: a opção por uma planta quadrada; o posicionamento dos programas administrativos no térreo e a liberação do solo para o acesso dos sócios à área esportiva conformando uma praça coberta; os acessos e instalações de serviços no subsolo. Porém, neste período, Penteado e a vanguarda moderna paulista produziam uma arquitetura com linguagem muito distinta daquela que remetia à arquitetura carioca. A nova proposta se apresentava em consonância aos projetos dos colegas da vanguarda moderna paulista, com ênfase na tensão do estrutural, entre a laje de grande vão e seus pilares, ambos em concreto aparente, com dissociação entre a forma contínua da cobertura e as lajes de piso em meios-níveis intercalados, a interiorização da paisagem com ênfase a continuidade espacial, exteriormente as empenas de concreto se referenciam ao projeto para o edifício da FAU-USP, de 1961, de Vilanova Artigas.

O projeto apresenta o edifício-sede configurado por um volume único, delimitado pela cobertura de aproximadamente $46 \mathrm{~m} \times 42,5 \mathrm{~m}$. A partir de uma malha de $1,70 \mathrm{~m} \times 1,70$, a cobertura é estruturada por uma laje nervurada em dois sentidos, de 27 módulos de frente por 25 módulos de profundidade, apoiada no ritmo de 3/6/9/6/3 (frente e fundo) e 3/6/6/6/3 (laterais) em 12 
pilares de seção cruciforme, periféricos e recuados a 3 módulos do perímetro externo. Seus beirais são vazados, com exceção de duas passagens para o acesso da entrada e passagem para a piscina, e a área interna do edifício é coberta contendo algumas aberturas zenitais em domos de iluminação e ventilação distribuídos de acordo com os ambientes internos. Os fechamentos verticais são compostos por empenas cegas e caixilharia de vidro temperado incolor.

$\mathrm{Na}$ área compreendida entre o passeio público e o edifício, os arquitetos redesenham a área de embarque e desembarque, que já havia na antiga sede e propõem vagas para o estacionamento de automóveis, junto à rua Canadá.

Atendendo à exigência do programa, a proposta apresenta um edifício a ser construído em duas etapas. Para a primeira fase, era prevista uma edificação de dois pavimentos na frente do lote. Considerando o passeio público como cota 0 , no térreo, cota $+1,25 \mathrm{~m}$, estaria localizada a recepção (entrada); área de leitura e setor administrativo. No primeiro pavimento, na cota $+4,15 \mathrm{~m}$, estaria a área de jogos, salas para carteado, sala de TV e bar. Uma escada helicoidal provisória, sob o beiral, interligava os andares.

O projeto ocupava o subsolo, na cota $+0,05 \mathrm{~m}$, ao fundo do lote, onde estariam os sanitários para uso dos associados, sala de estar e sala de TV. Um acesso na lateral do edifício para os funcionários que desceriam ao subsolo, na cota $+0,05 \mathrm{~m}$, onde estaria a recepção de serviços, portaria para funcionários, sanitários para funcionários e área da cozinha (área de recepção e preparação de alimentos, adega, despensa e câmaras frias). Um elevador para alimentos e uma escada para funcionários interligaria a cozinha do subsolo à cozinha do salão na cota $+2,65 \mathrm{~m}$, a ser construída na segunda etapa.

Para a segunda fase estavam previstos dois tramos de escadas, conformando três patamares amplos que ocupariam quase toda a extensão transversal do edifício. O programa de extensão do edifício se distribuía a partir do patamar da cota $+2,65 \mathrm{~m}$, onde estava localizada a sala de estar, restaurante e cozinha, em volume cônico posicionado na área livre; o último patamar, na cota $+3,55 \mathrm{~m}$, outra sala de estar, bar e áreas para mesas externas, sob o beiral ao fundo do edifício. Situava-se neste patamar, uma outra escadaria interligava a cota $+4,45 \mathrm{~m}$, onde estava localizada a piscina. Sobre a área da secretaria os recuos laterais possuem tratamento paisagístico.

A seguir, reproduzimos o Memorial Explicativo da folha 11 da proposta de Penteado:

Preliminares:

Ligação visual com a piscina; garantia da intimidade do clube em relação aos lotes vizinhos; ambientação interna sugestiva, para os dias comuns (de pouca frequência) e para os dias de festa.

A Solução:

A planta do edifício é toda definida pelos cortes no terreno e pela forma solta da copa-cozinha. As pequenas diferenças de nível não cortam a integração do interior, com os entornos da piscina, e oferecem várias sugestões de arranjos, caracterizando também os grandes espaços livres para os dias de festa.

\section{A Cobertura:}

Em todo o interior do clube, a cobertura é um grande painel de concreto, marcado várias vezes por entradas de luz e composição de cores. A variação de efeitos de luz facilitará os arranjos internos.

\section{As Laterais}

As empenas laterais e o pergolado (que funciona como quebra-sol) formam varandas ajardinadas que eliminam todo o contato visual com os lotes vizinhos e ao mesmo tempo, alargam os espaços internos, propiciando ainda efeitos de iluminação em toda a volta do edifício.

\section{A 1 1 Fase:}

A 1․ Fase ocupou (em dois pisos), apenas 11 metros dos 14 permissíveis. Os três metros de afastamento da construção atual facilitarão os trabalhos de arrimos e cimbramento da cobertura. Para ligação dos dois pisos, na 1a Fase, será usada [usou-se] uma escada provisória.

\section{Solução Estrutural:}

A cobertura é uma grelha ortogonal de concreto armado, com altura adequada (1.70), que permite esbeltez nas peças componentes e está apoiada em 12 pilares recuados em relação ao perímetro, com balanços, em pérgola, e sustentando as empenas de fecho. A laje de cobertura é constituída de placas armadas de concreto alveolar extra-leve com juntas armadas e rejuntadas no local. 


\section{Estrutura na 1ํ Fase:}

O painel de cobertura correspondente à $1^{\text {a }}$ Fase está apoiado em 3 lados. 04 .o lado, terá além da cobertura da 1a Fase, um módulo a mais executado e que ficará à espera da estrutura da $2^{a}$ Fase com a qual se solidarizará, não sofrendo o conjunto solução de continuidade. Em toda a extensão deste 4.o lado será mantida uma linha de cimbramentos, para a execução da 2.a etapa de obra.

Na 1a Fase, o piso superior (jogos), está sustentado de um lado pelo peitoril externo e do outro, por vigas que descarregam em pilares internos.

Para a proteção da construção existente, durante as obras da 1â Fase, será executada uma cortina temporária para submuração da parede lindeira, a fim de permitir as escavações necessárias.

A 1- Fase pode funcionar independente das obras da $2^{\text {a }}$ Fase e contém todas as áreas pedidas no programa. O único elemento provisório será uma escada externa de ligação ao piso superior (jogos).

Áreas:

1.a Fase $865,80 \mathrm{~m} 2$

2a Fase $\quad 1.228,90 \mathrm{~m} 2$

Área Total $1.994,20 \mathrm{~m} 2$

O edifício proposto pela equipe, embora recue em $10 \mathrm{~m}$ o perímetro de fechamento do edifício, avança três módulos de $1,70 \mathrm{~m}$ cada, aproximadamente $5,10 \mathrm{~m}$, dos beirais da cobertura sobre os recuos laterais e afastamento frontal, o que impossibilitaria a sua aprovação pela Cia. City. 


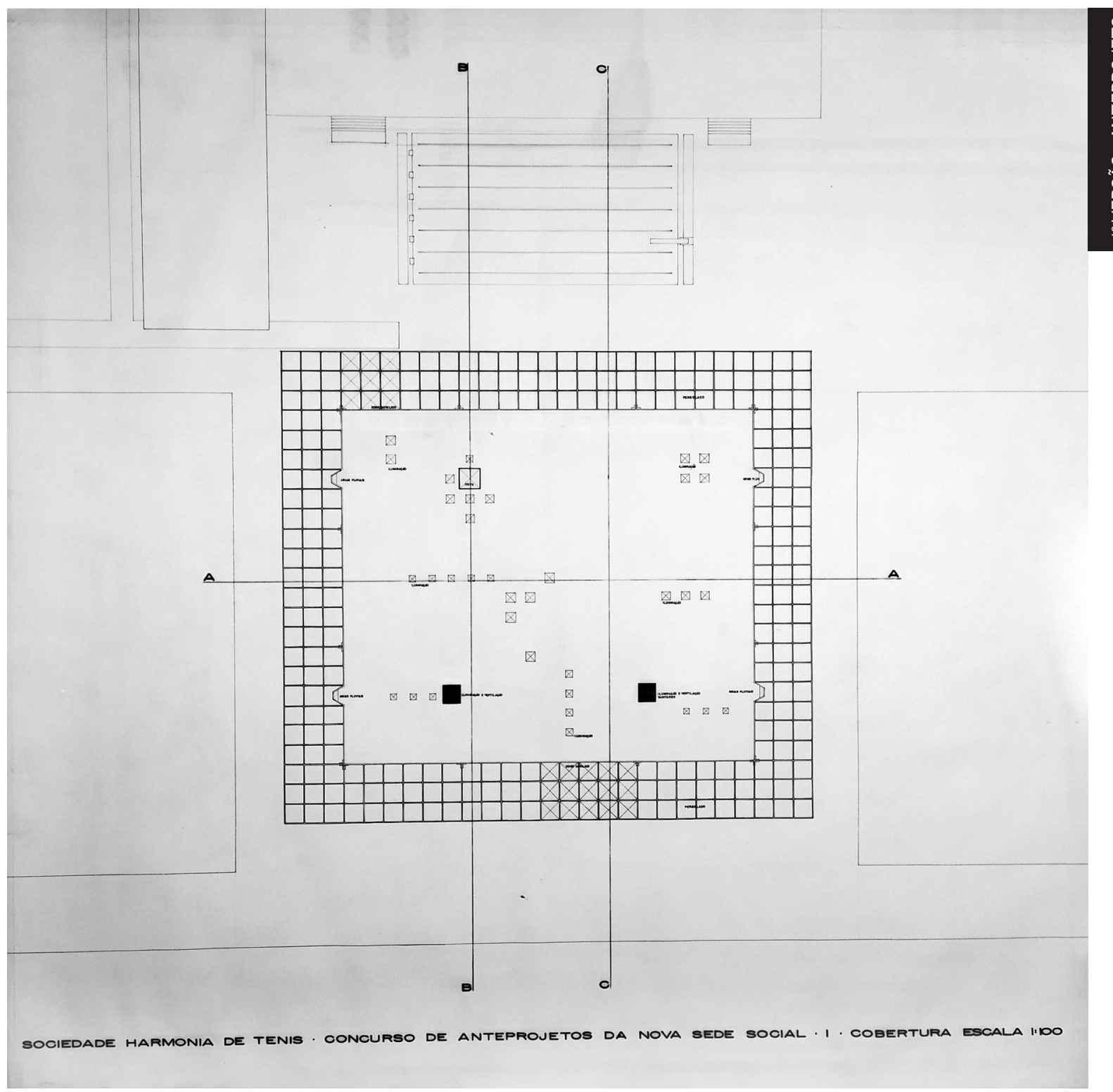

$75 \uparrow$ Folha 1, Planta - Estudo para o Concurso de Anteprojetos da Sociedade Harmonia de Tênis, São Paulo, 1964.

Fonte: Acervo do Arquivo Fábio Penteado. 


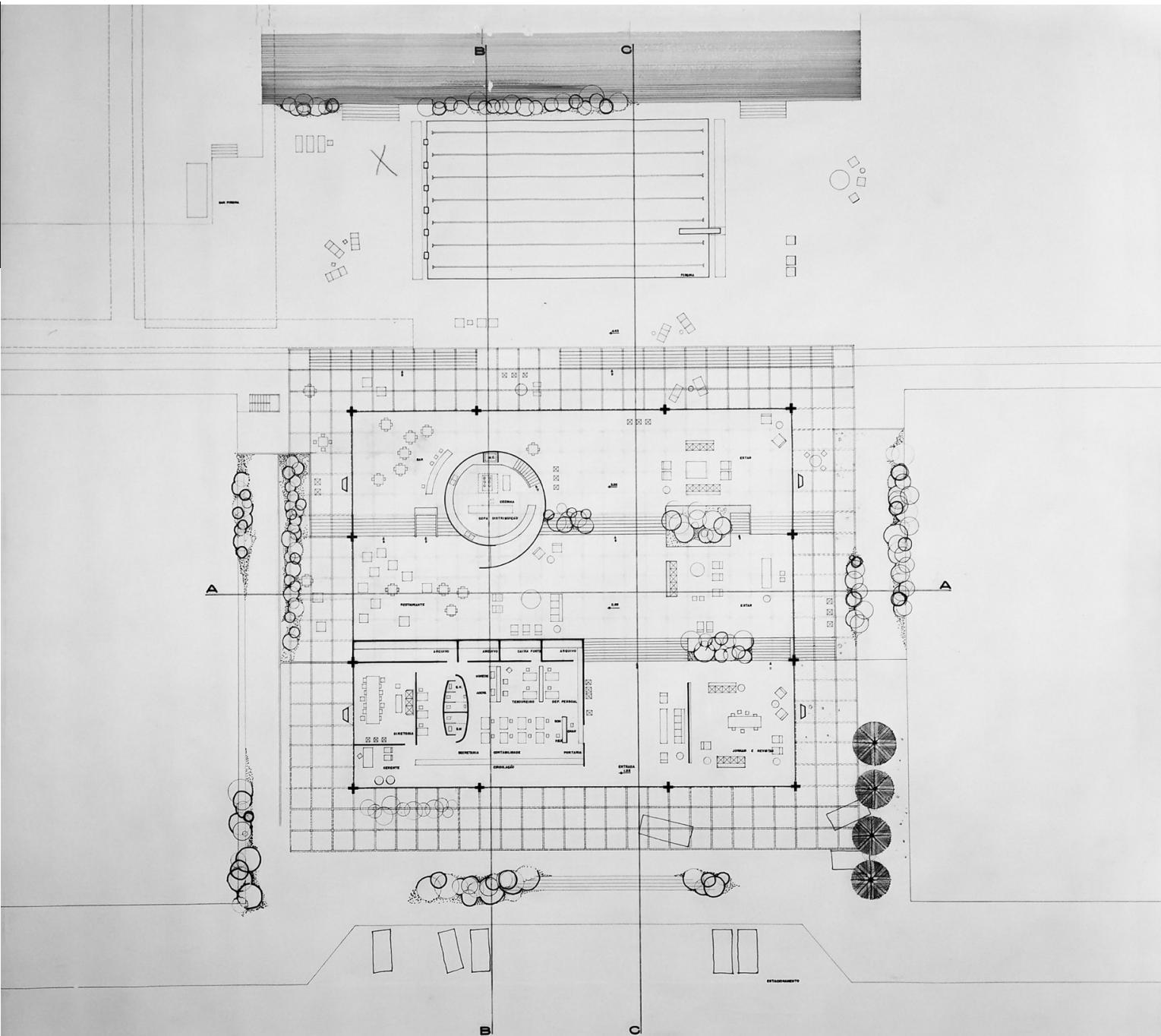

SOCIEDADE HARMONIA DE TENIS . CONCURSO DE ANTEPROJETOS DA NOVA SEDE SOCIAL. 2 . PLANTA ESOALA I:IOO 


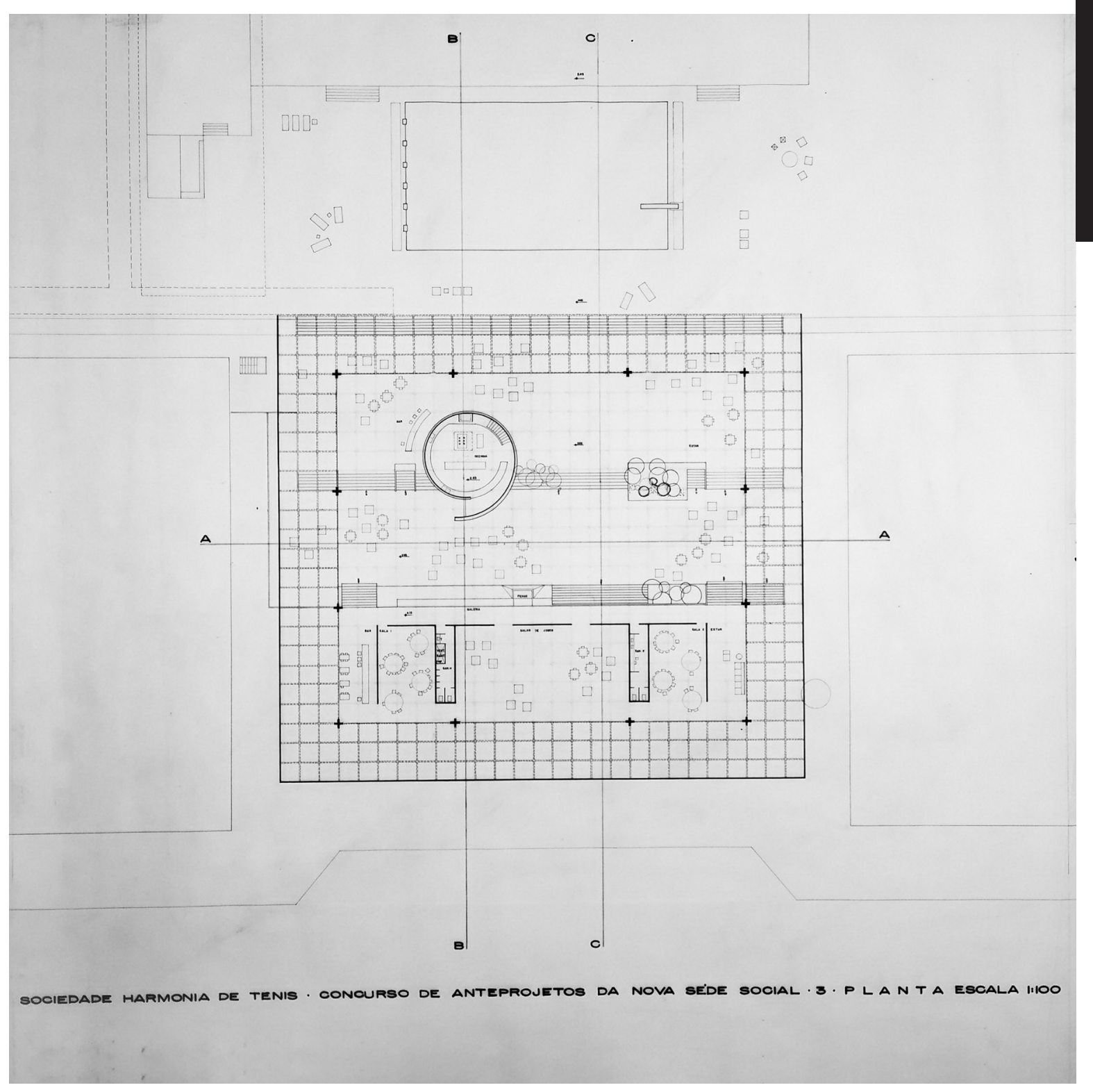




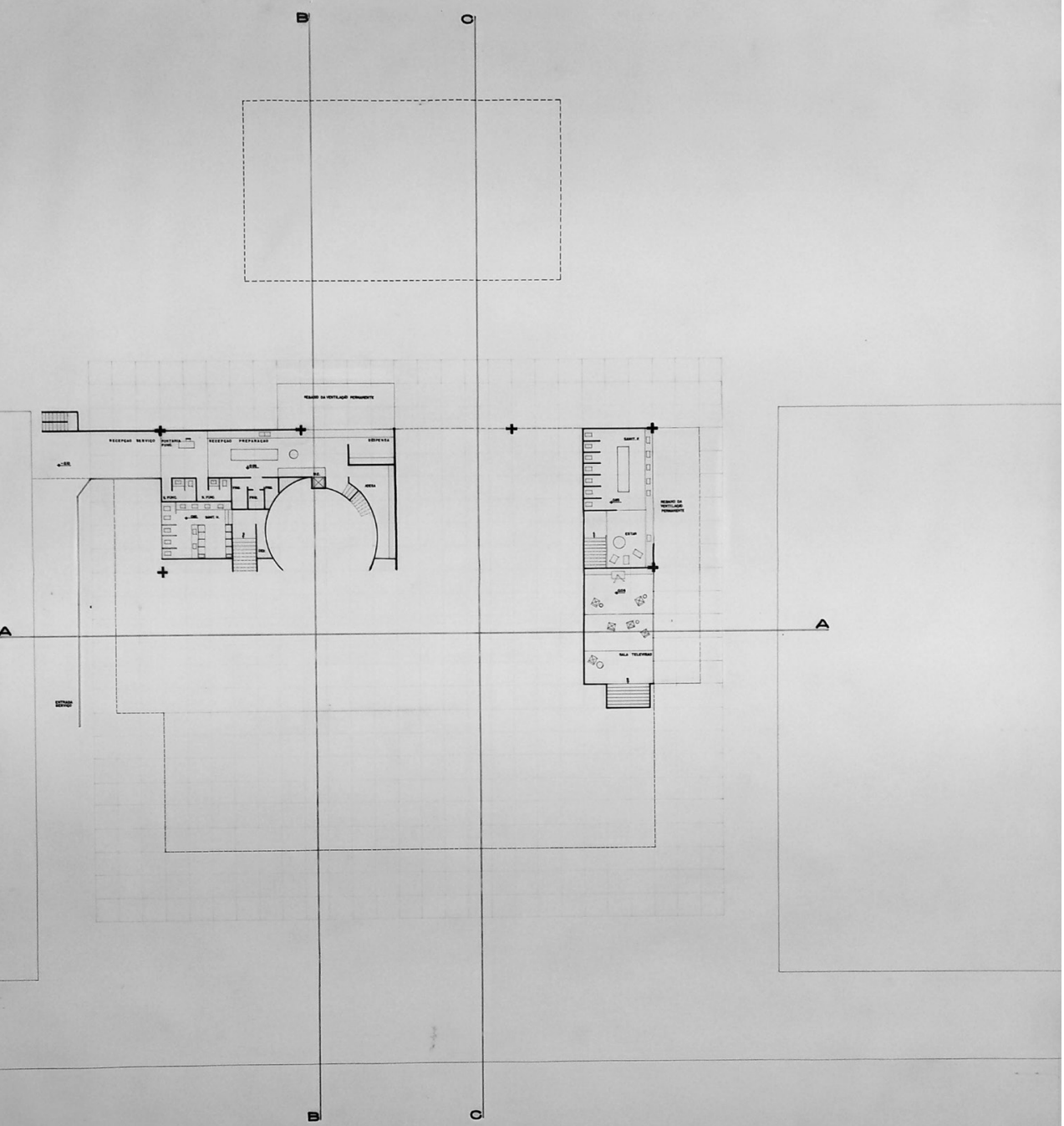

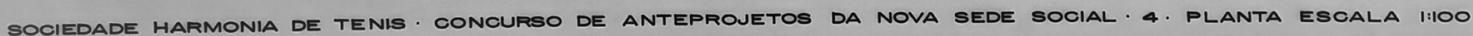

Fonte: Acervo do Arquivo Fábio Penteado. 


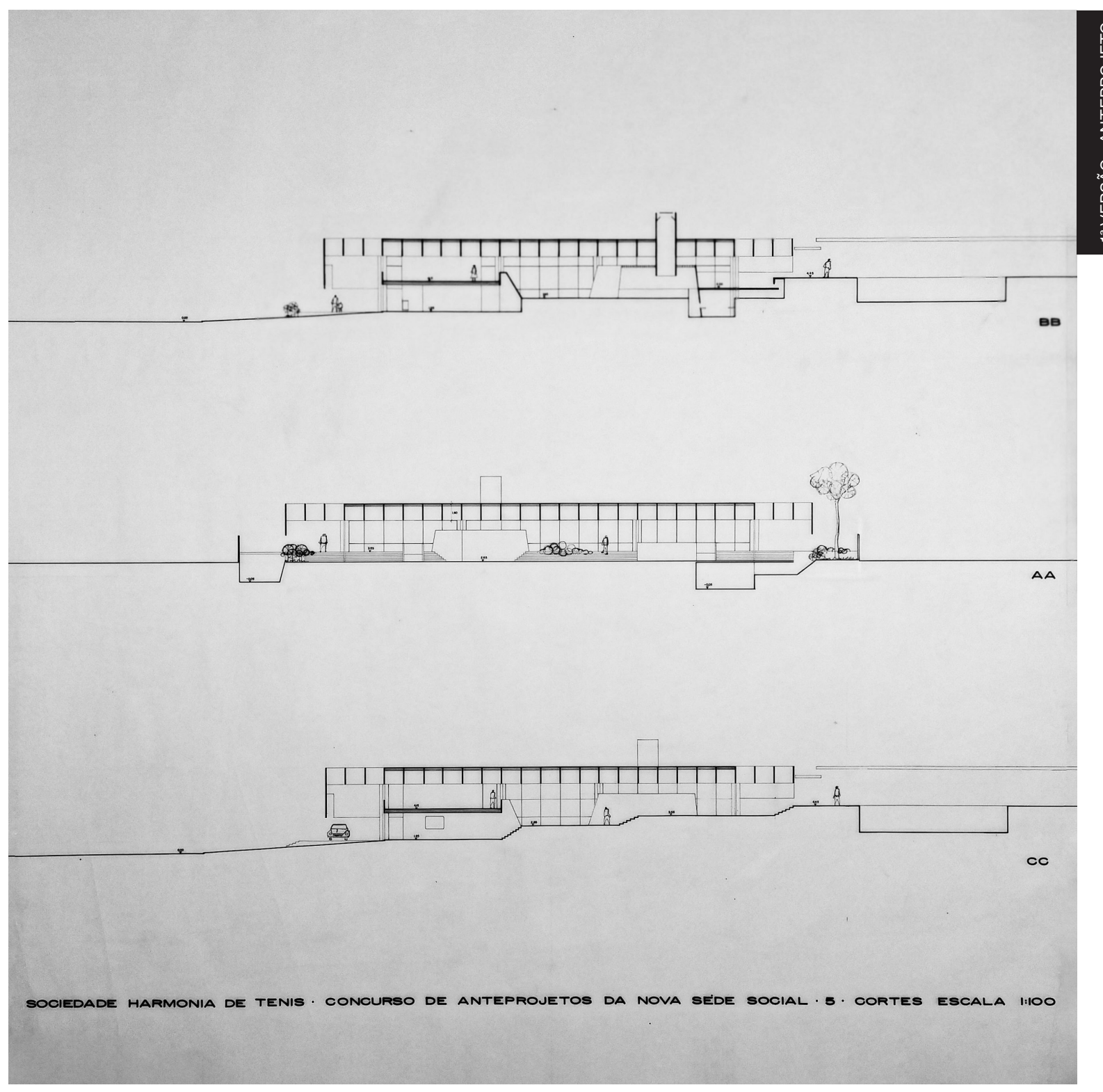

$79 \uparrow$ Folha 5, Cortes - Estudo para o Concurso de Anteprojetos da Sociedade Harmonia de Tênis, São Paulo, 1964.

Fonte: Acervo do Arquivo Fábio Penteado. 


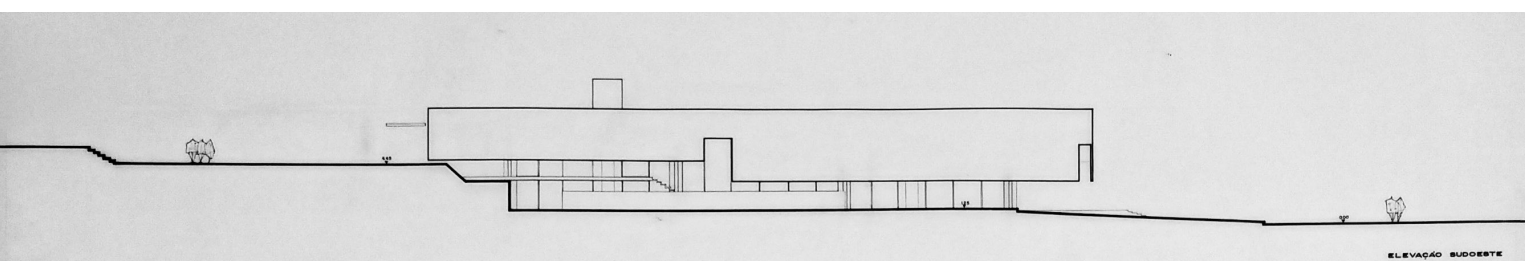

ELEvagio sudozote
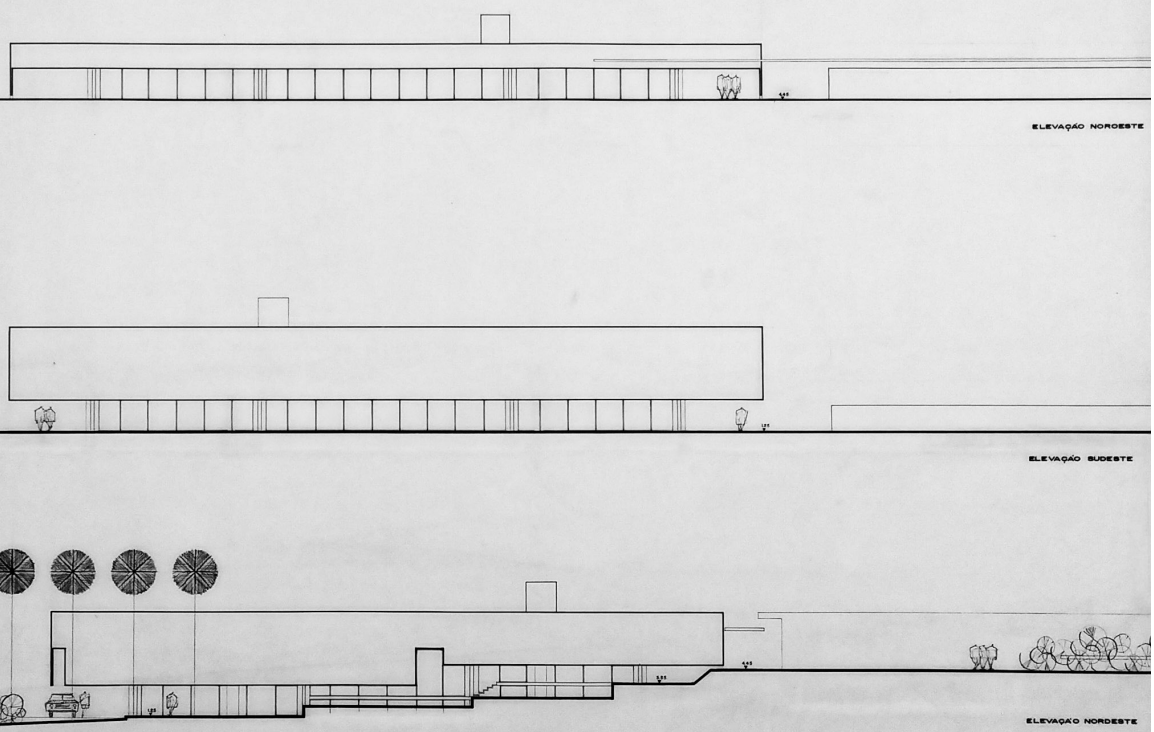

SOCIEDADE HARMONIA DE TENIS - CONCURSO DE ANTEPROJETOS DA NOVA SEDE SOCIAL . G . ELEVACOES ESCALA I:IOO

Fonte: Acervo do Arquivo Fábio Penteado. 


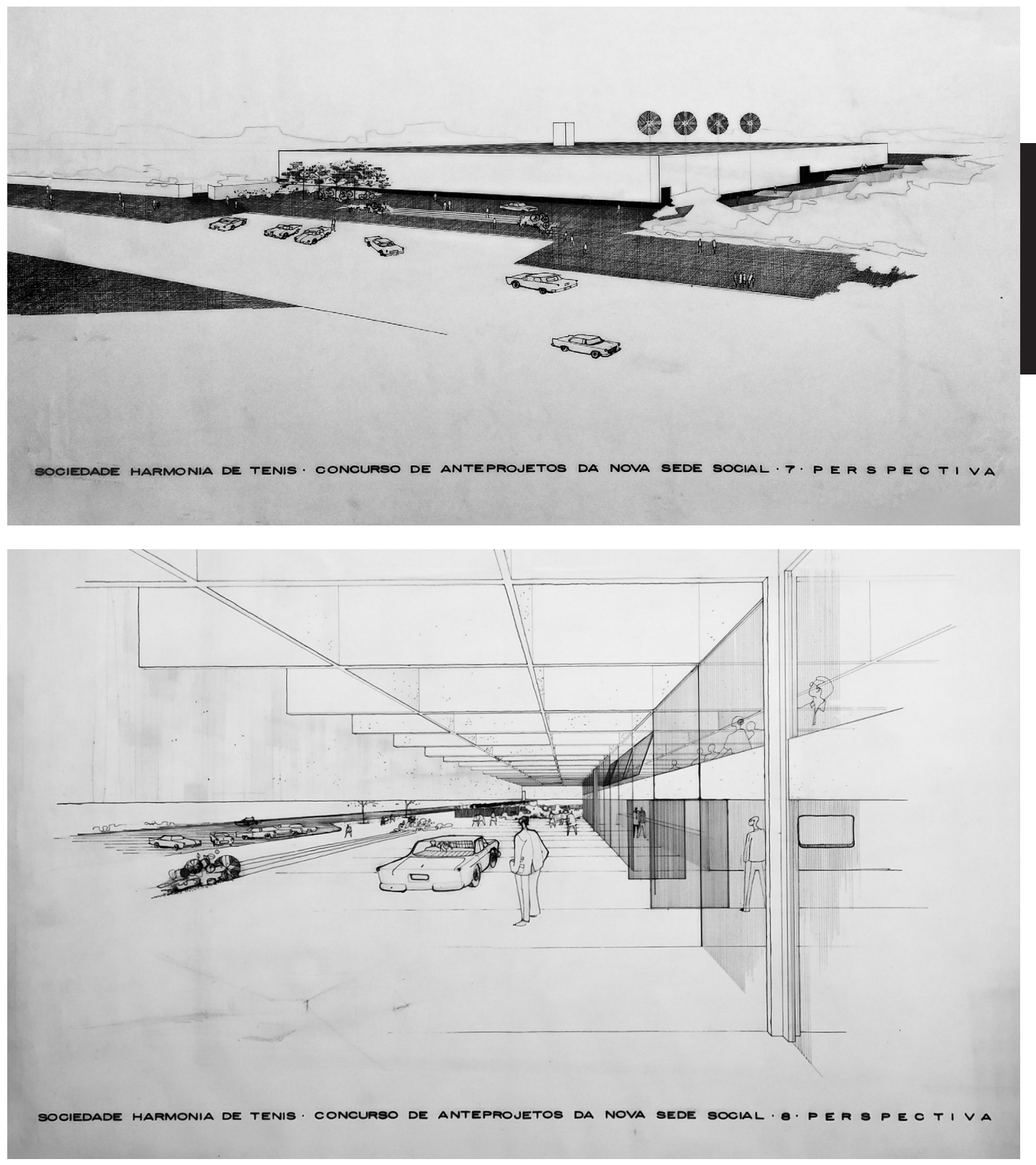

$81 \uparrow$ Folha 7, Perspectiva - Estudo para o Concurso de Anteprojetos da Sociedade Harmonia de Tênis, São Paulo, 1964. Fonte: Acervo do Arquivo Fábio Penteado.
$82 \uparrow$ Folha 8, Perspectiva - Estudo para o Concurso de Anteprojetos da Sociedade Harmonia de Tênis, São Paulo, 1964. Fonte: Acervo do Arquivo Fábio Penteado. 


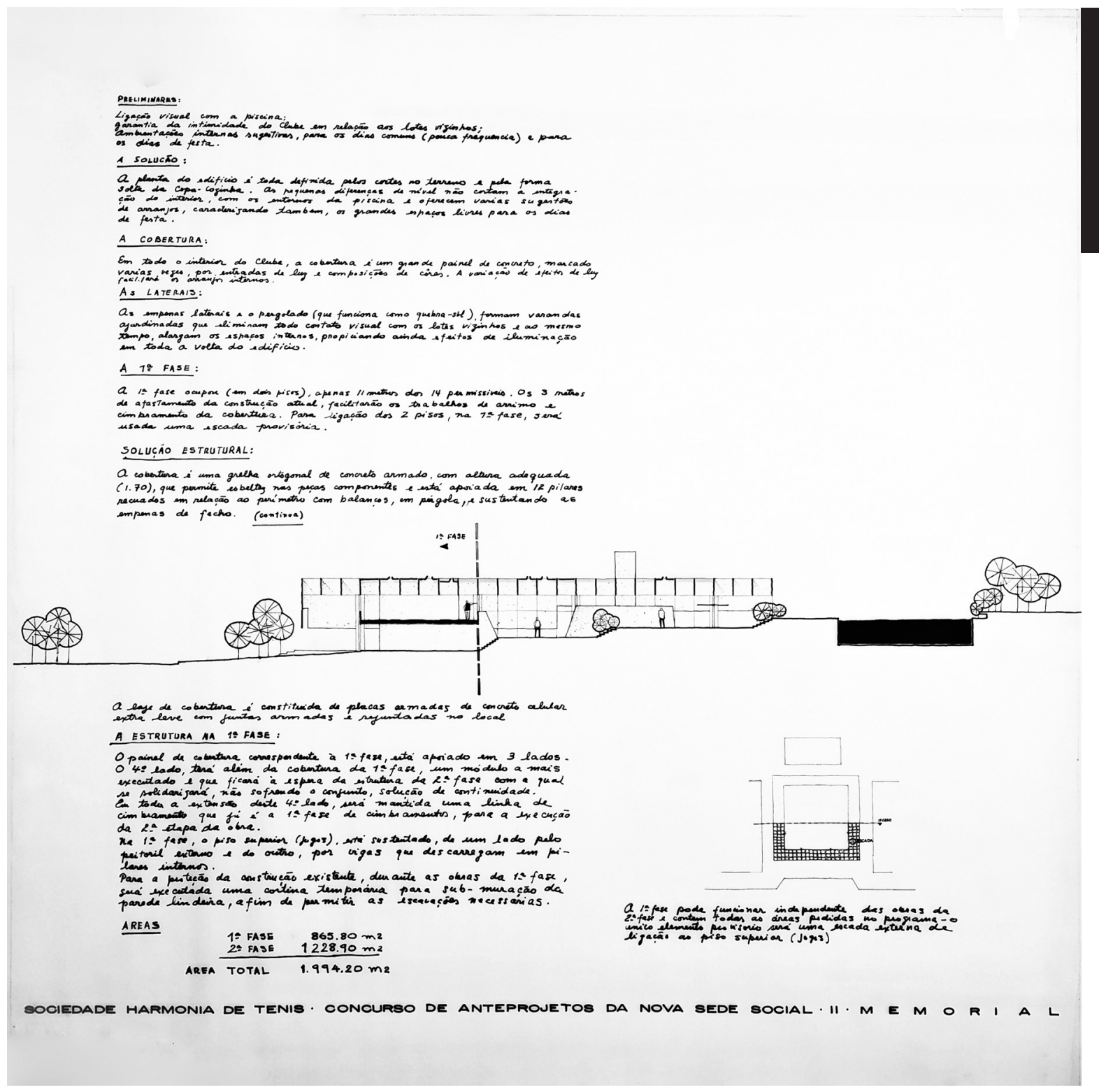

$85 \uparrow$ Folha 11, Memorial Explicativo - Estudo para o Concurso de Anteprojetos da Sociedade Harmonia de Tênis, São Paulo, 1964.

Fonte: Acervo do Arquivo Fábio Penteado. 


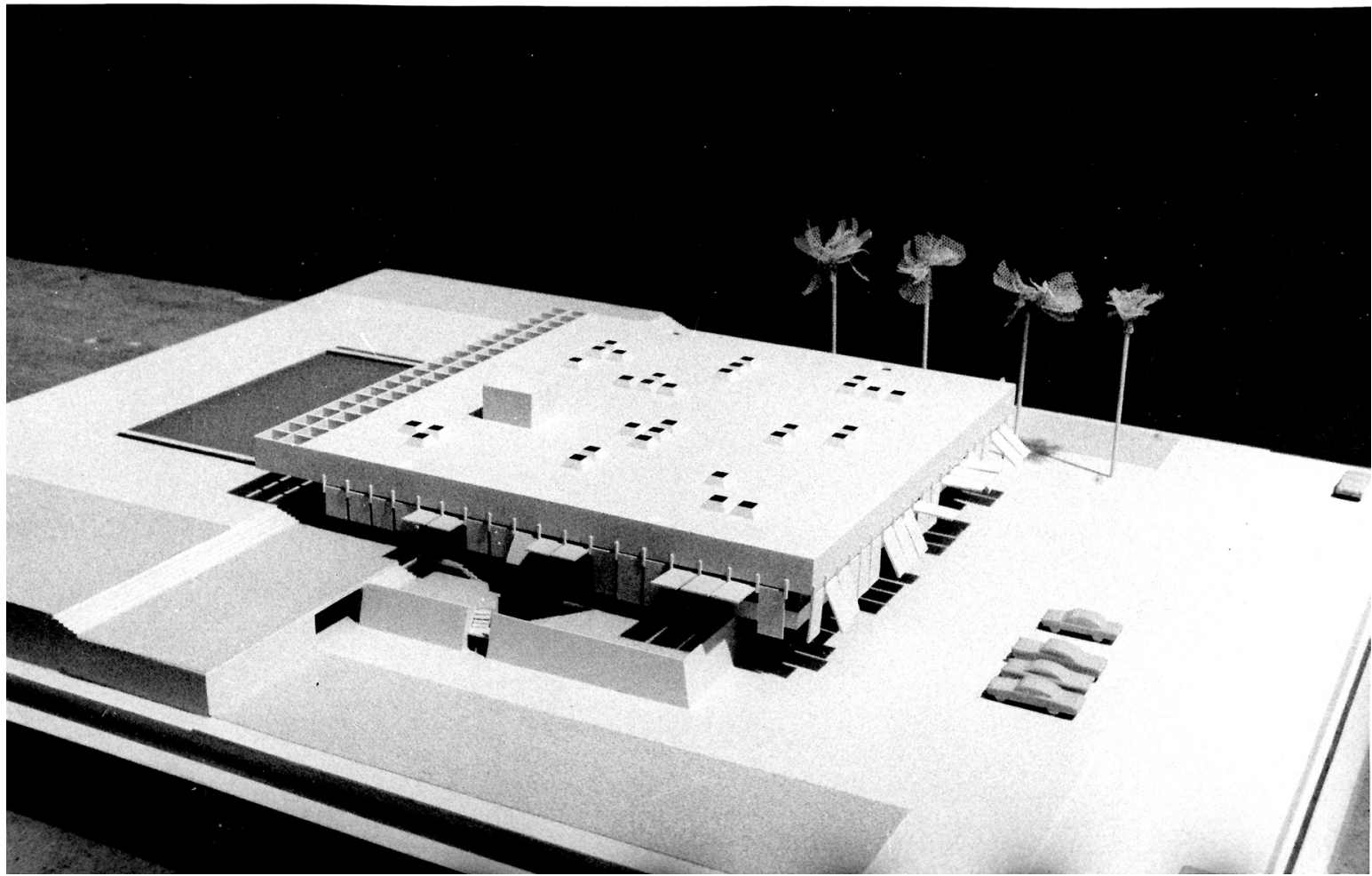

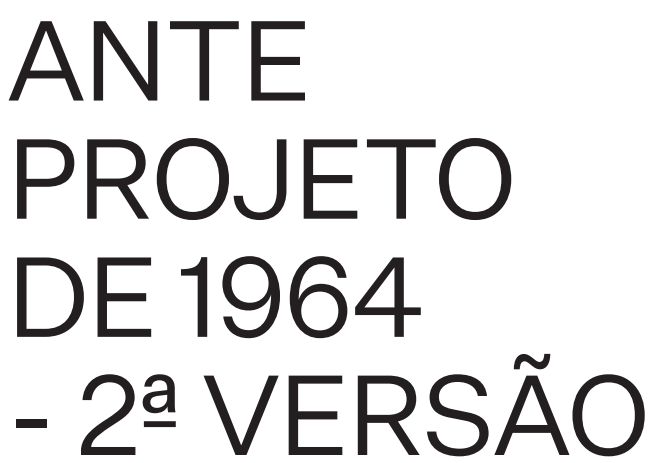

Em 3 de dezembro de 1964, três dias após a entrega dos projetos, os concorrente receberam o "Termo de Complementação de Concurso de Arquitetura", o qual informava que os trabalhos entregues não foram aceitos pelo júri. O IAB, representado pelo seu presidente, Arq. Alberto Rubens Botti, decidiu pela continuidade do concurso, solicitando a revisão dos anteprojetos. O Termo introduziu uma nova cláusula ao edital validando a permanência do antigo regulamento, exceto a escala dos desenhos exigidos, alterada para 1:200, e proibiu a apresentação de qualquer perspectiva, obrigando-se o vencedor a entregá-las em data posterior. A nova entrega do concurso deveria ocorrer em 15 dias, passando para 14 de dezembro de 1964 e o ato de encerramento em 18 de dezembro de 1964.

O conjunto de desenhos definitivos entregue pela equipe de Fábio Penteado formavam sete pranchas e organizava-se em plantas (folhas 1 a 4); cortes (folha 5); elevações (folha 6); e memorial explicativo (folha 7).

$\mathrm{O}$ projeto se adequa às exigências de recuos e afastamentos da Cia. City e contém outras duas alterações marcantes em relação à primeira versão: $\mathrm{O}$ recuo frontal é transformado em estacionamento, um auditório para 250 pessoas é proposto no subsolo e a fachada frontal e as laterais possuem brises articuláveis com venezianas metálicas.

$86 \uparrow$ Maquete - Estudo para o Concurso de Anteprojetos da Sociedade Harmonia de Tênis, São Paulo, 1964. Fonte: Acervo do Arquivo Fábio Penteado. 
A seguir, reproduzimos o Memorial Explicativo da folha 7 da proposta de Penteado:

Preliminares:

Interação visual da sede com a piscina

Isolamento dos lotes vizinhos

Flexibilidade de uso:

- para os dias comuns (pouca frequência)

- para os dias de festa (grande frequência)

\section{A Solução:}

A planta do edifício é toda definida pelos cortes no terreno e pela forma solta da copa-cozinha. As pequenas diferenças de nível "não cortam" os ambientes, mas oferecem sempre perspectivas novas para os arranjos de interiores, que podem ser variados.

\section{A Cobertura:}

Em todo o interior do clube, a cobertura é um grande painel de concreto, marcado muitas vezes por entradas de luz e composição de cores. A variação de efeitos de luz (maiores ou menores aberturas no teto), formará no interior espaços caracterizados, de acordo com os arranjos desejados.

\section{Auditório (proposição)}

O programa não cogitou de um auditório, todavia vem sendo normal, entre as atividades do clube, reuniões de caráter cultural, científico, etc., em locais improvisados e não condizentes.

A proposta de uma auditório para aproximadamente 250 pessoas parece vir ao encontro de uma necessidade real e atual do clube.

Acesso e Estacionamento:

A entrada do clube é uma pequena praça (+ ou $1.300 \mathrm{~m} 2$ ) que facilita o acesso, estacionamento e entrada abrigada. O tratamento paisagístico deverá ser em função do próprio uso da praça, com desenhos de piso, indicando os locais de estacionamento e conjuntos de árvores para o sombreamento de veículos.

\section{Cortina de Venezianas:}

Em toda a volta do edifício (exceto a face da piscina), haverá cortinas (persianas metálicas), fixadas nas extremidades da grelha de cobertura. As venezianas são fixas; todavia haverá várias delas móveis, por onde serão abertas grandes faixas, para comunicação com os jardins laterais, onde vegetação densa, fará a vedação com relação aos vizinhos.

\begin{abstract}
A Primeira Fase
A 1 a Fase é prevista para funcionar de acordo com o programa pedido, com um único elemento provisório, que é a escada de acesso ao piso de jogos.
\end{abstract}

\section{Solução Estrutural:}

A cobertura é uma grelha ortogonal de concreto armado, com altura adequada (1.70), para permitir esbeltez nas peças componentes.

O conjunto se apoia em 12 pilares, recuados um módulo, em relação ao perímetro.

A laje de cobertura é constituída de placas armadas de concreto alveolar extra-leve, com juntas armadas e rejuntadas no local.

$\mathrm{Na} 1^{\text {a }}$ Fase, o painel de cobertura está apoiado em 3 lados. O 4.o lado será mantido em toda a sua extensão, por uma linha de cimbramento e ficará à espera da estrutura restante ( $2^{\mathrm{a}}$ Fase), com a qual se solidarizará, não sofrendo o conjunto, no final, solução de continuidade.

Estes cimbramentos já passam a ser a 1.a linha de cimbramentos para a execução da estrutura, na $2^{\mathrm{a}}$ Fase. A laje superior (jogos), que tem um balanço de 3,60, terá apoios de pilares e cortinas de concreto, de acordo com a distribuição da planta térrea.

Para a proteção da construção existente, durante as obras da 1a Fase, será feita uma cortina temporária para submuração, para as escavações necessárias.

$\begin{array}{ll}\text { Áreas: } & \\ \text { 1a Fase } & 868,50 \mathrm{~m} 2 \\ 2^{\text {a }} \text { Fase } & 983,50 \mathrm{~m} 2 \\ \text { Área Total } & 1.852,00 \mathrm{~m} 2 \\ \text { Auditório } & 220,00 \mathrm{~m} 2\end{array}$

$2.072,00 \mathrm{~m} 2$

O conjunto de desenhos definitivos entregue pela equipe de Fábio Penteado, formavam sete pranchas e organizava-se em plantas (folhas 1 a 4); cortes (folha 5); elevações (folha 6); e memorial explicativo (folha 7). 


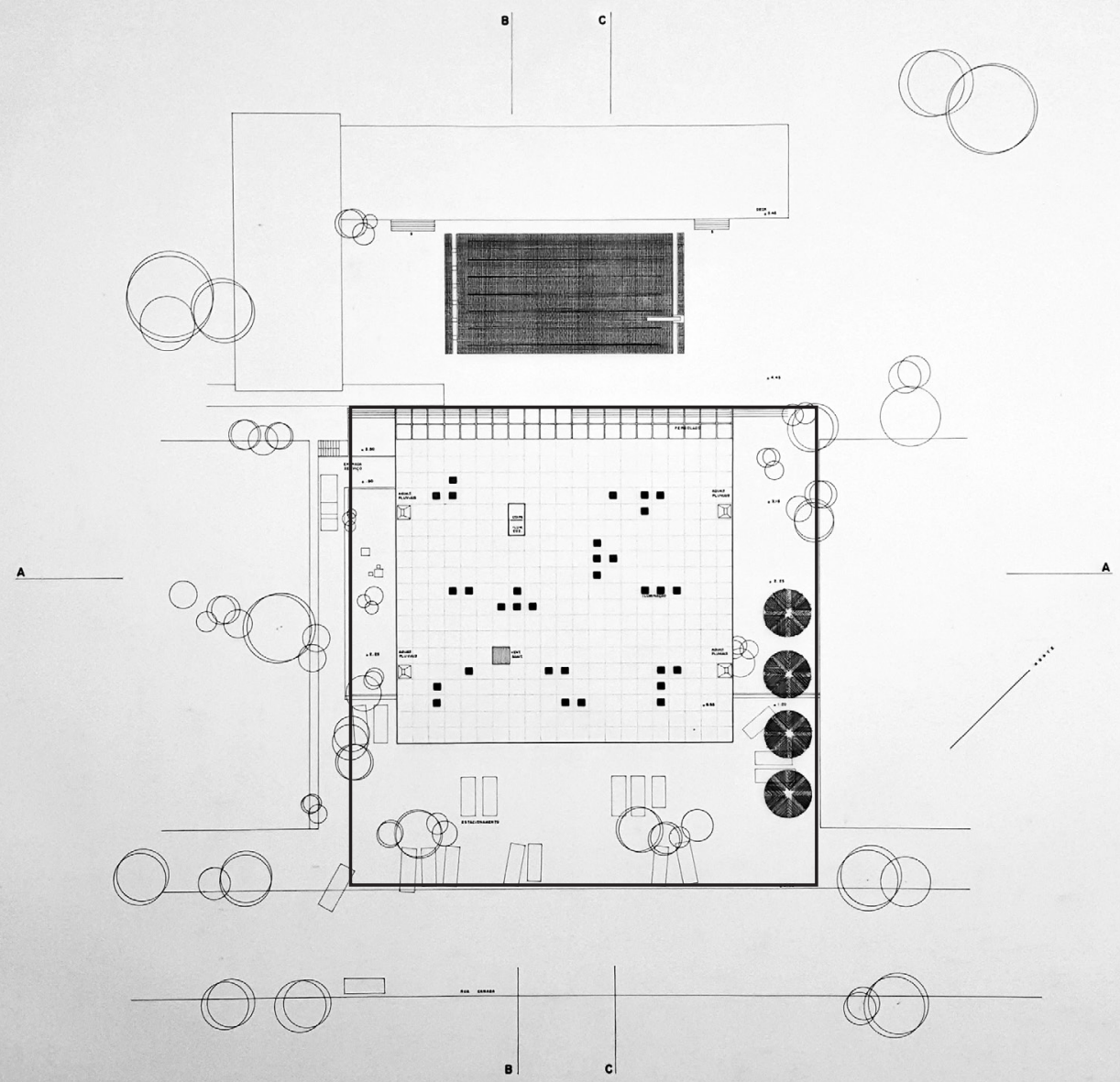

SOGIEDADE HARMONIA DE TENIS

CONOURSO DE ANTEPROJETO DA NOVA SEDE SOCIAL

PLANTA Escala 1.200 


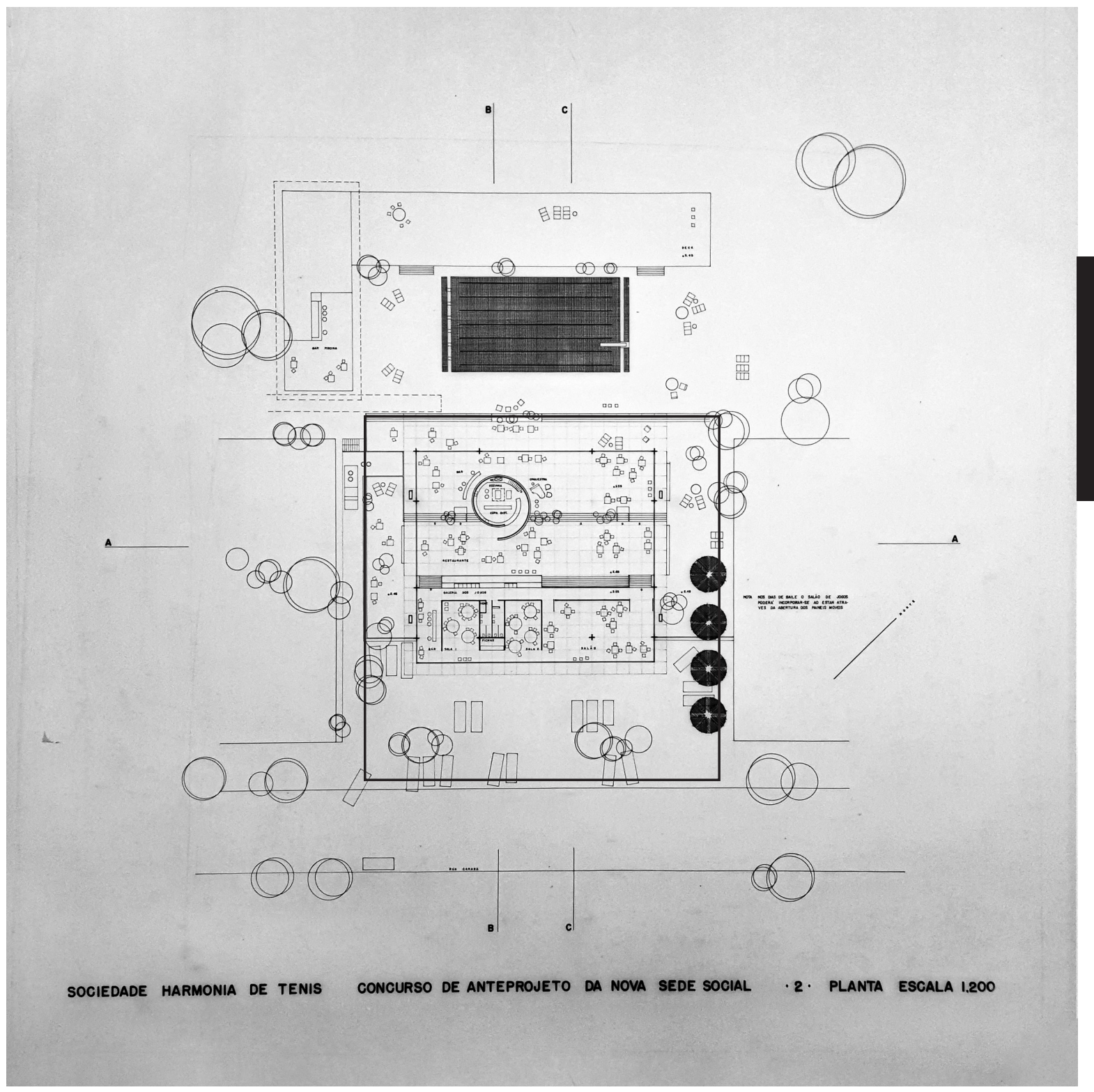

$88 \uparrow$ Folha 2, Planta - Estudo para o Concurso de Anteprojetos da Sociedade Harmonia de Tênis, São Paulo, 1964.

Fonte: Acervo do Arquivo Fábio Penteado. 


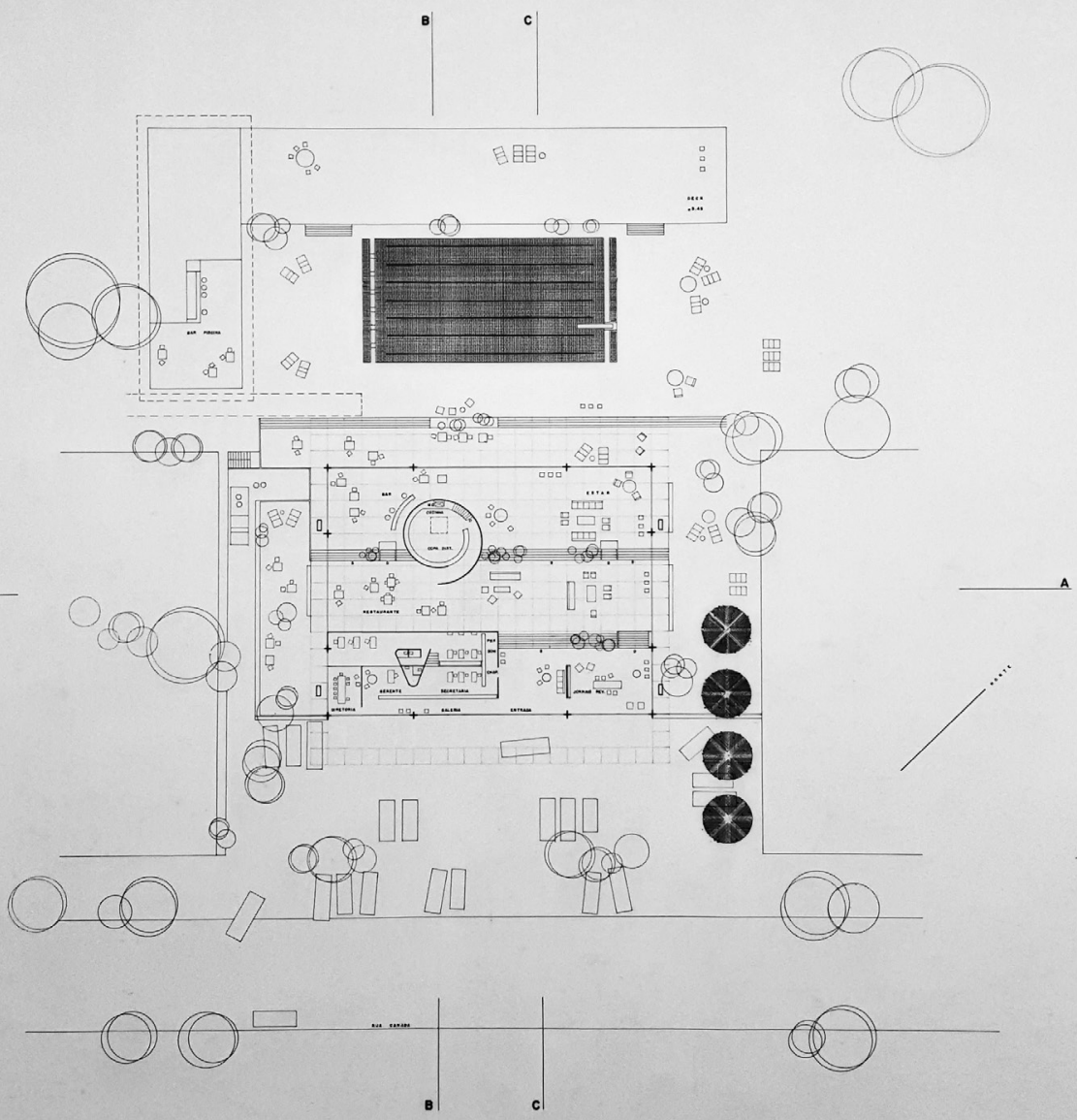

SOGIEDADE HARMONIA DE TENIS CONCURSO DE ANTEPROJETO DA NOVA SEDE SOGIAL · 3. PLANTA ESCALA I.200 


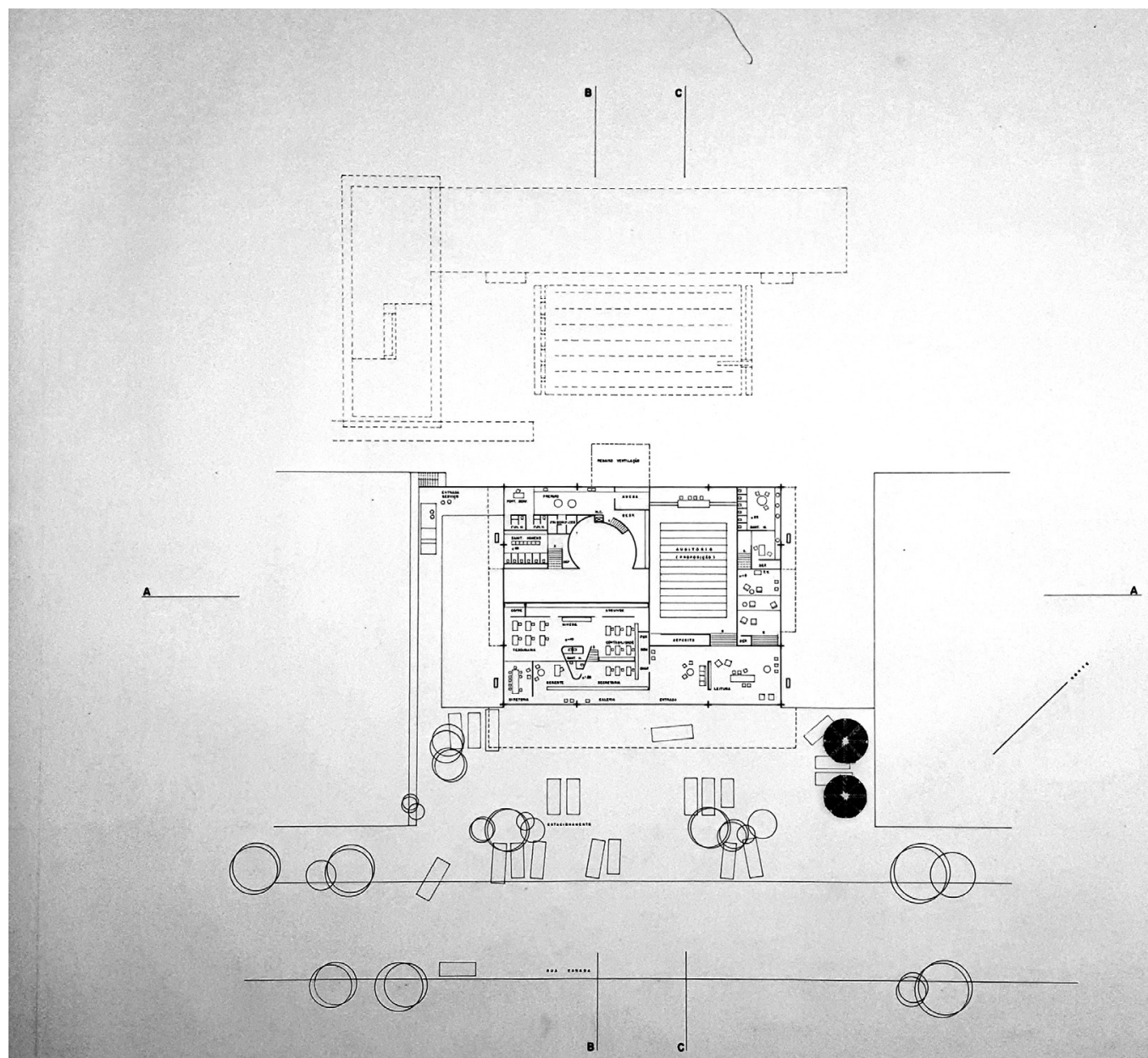

SOGIEDADE HARMONIA DE TENIS

CONGURSO DE ANTEPROJETO DA NOVA SEDE SOCIAL

4. PLANTA ESCALA 1.200

$90 \uparrow$ Folha 4, Planta - Estudo para o Concurso de Anteprojetos da Sociedade Harmonia de Tênis, São Paulo, 1964.

Fonte: Acervo do Arquivo Fábio Penteado. 

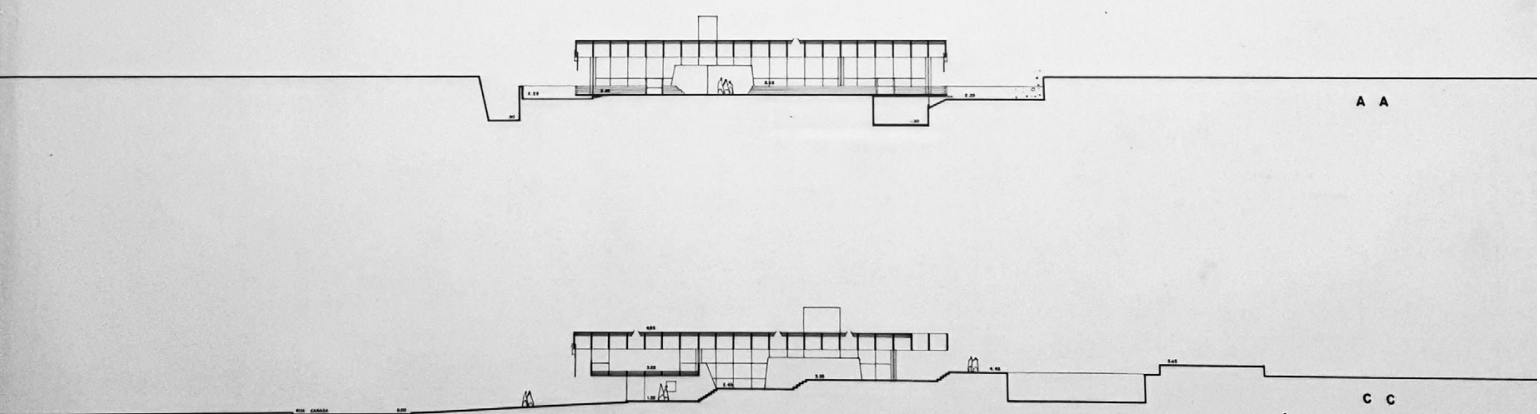

SOCIEDADE HARMONIA DE TENIS

CONCURSO DE ANTEPROJETO DA NOVA SEDE SOCIAL . 5 . CORTES ESCALA I.200

$91 \uparrow$ Folha 5, Cortes - Estudo para o Concurso de Anteprojetos da Sociedade Harmonia de Tênis, São Paulo, 1964.

Fonte: Acervo do Arquivo Fábio Penteado. 


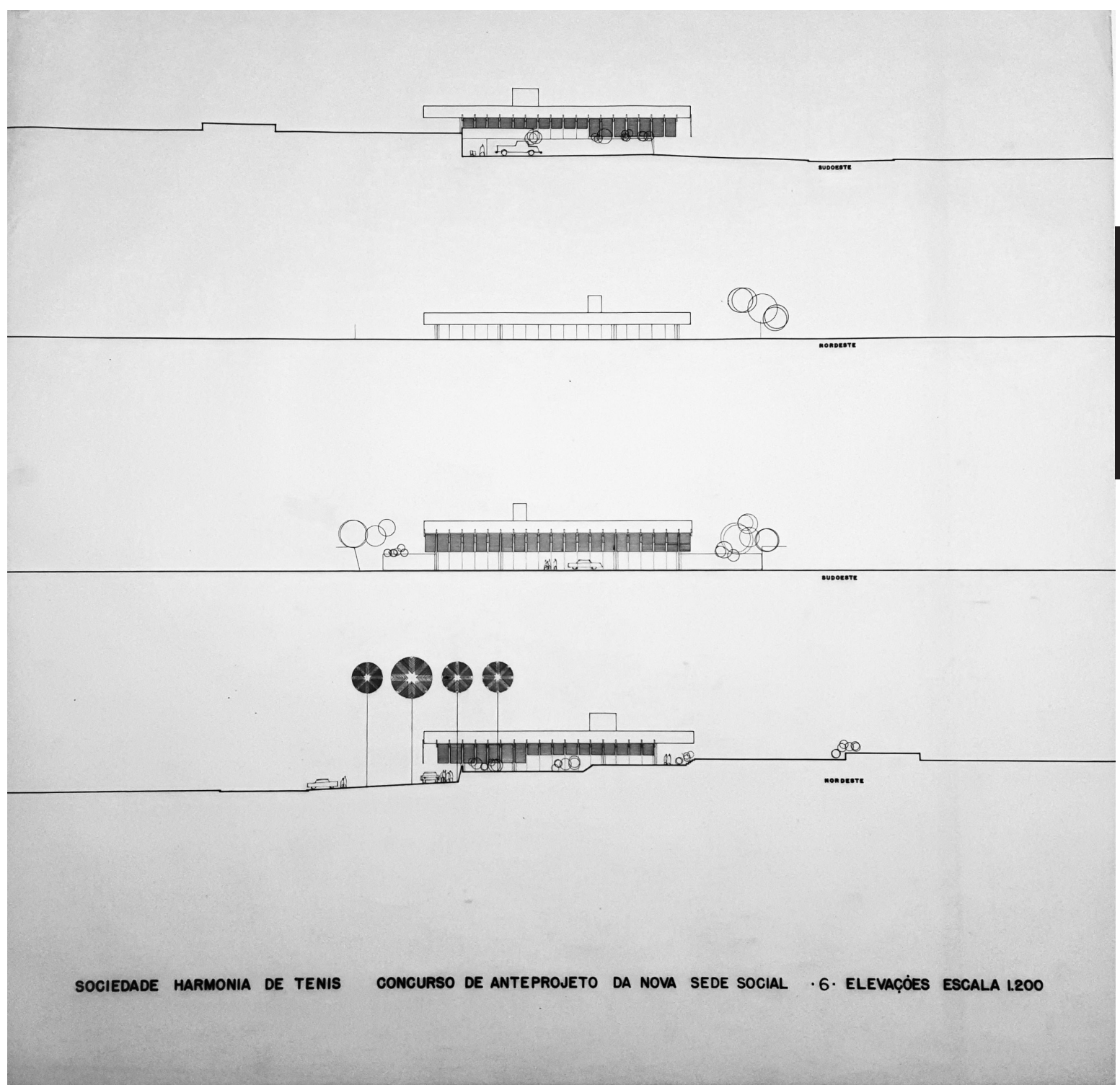

$92 \uparrow$ Folha 6, Elevações - Estudo para o Concurso de Anteprojetos da Sociedade Harmonia de Tênis, São Paulo, 1964.

Fonte: Acervo do Arquivo Fábio Penteado. 


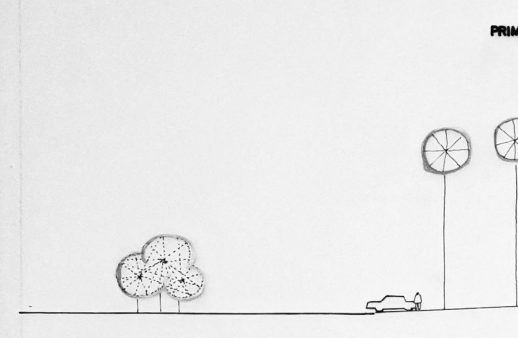

- PRELiminares Integacaro visual da side com a piscina.
Isolamento dos botes vijinkios

Terriblidade do uso para os dias comens (pouca frequencia) Texribuldade do uso para os dias de festa (gande a flumencia) Solucäo adequada acesso e edacionamanto de

- a soluçá

A planta do edificio i toda definida pelos cortes no terreno el pela forma solta da copa-cozinhe. As pequenas diferences de mivel, nas cortam" os am bientes, mas oferecem sempere, peropectivas novas para os arranjis de interiores que podem ser

- a cobertura

Em todo o interior do clube, a cobertura é um grande painell de concreto, marcado mui tas vezes, por entradas de luze composiçós de côres. A variacias dos efeitos de luy (maiores ou menores aberturas no teto), forman no interior, espacos caracterizados, de acindo com os arranjos desejados.

- AUDITORIO (proposiçâo)

O programa näs cogitan de um anditoris, Todavia vem de carater cultural, cientificio ete. em bocais impresisado de canater condigentes. (contina)

SOCIEDADE HARMONIA DE TENIS
PRIMEIRA FASE

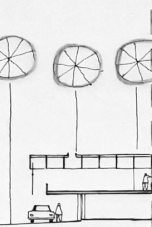

1 TRitis

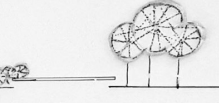

A proposta be um auditóris para apeoximadamente 250 pesióas parece vir de encontro

\section{- acesso e estalionamento}

A entrada do |clube é uma pequena praca $( \pm 1.300 \mathrm{mz})$ que facilita o acesso, estacionamento e entrod da abrigada. O tretamento paisagístico, deverá ser em funcōo do propsio uso da praca, com desentwos de piso, ina can árvares para $\mid b$ sombreamento de vé́culos.

\section{- cortina de venzzianas}

Em toda a volta do edíficio (exceto a face da piscina), havera cortinas (Anegianas metalicas), fixadas nas entre midades da jueha de cobertura. As venegianas sế fixas, todalia havera varias delas, movers, por onde seras pbertar grandes faixas, para comunicactas com os jardins laterdis, onde vegeta. ças dénsa, fard a vedacāos com as ciajinthos

\section{- a primeira fasi}

A la fase e previtta para funcionar, de acindo com 0 programa pedido, form um cinico elemento provisáris que i a escada de fesso as piso de jogo.

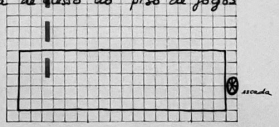

esquema estrutural

A cobertura é uma grelha ortogonal de concreto armado, com altura $(1,70 \mathrm{~m})$, adequada a permitir esbeltez nas pecas componentes. - confunto se apoia em 12 pilares, recuados um moduls, em relacas as perimetro. A laje de cobertura será constituida de placas armadas, de concreto celular extra-le
ve, com juntas armadas e rejuntadas no

Na 1I fase, o paind de cobertura está apoia do em 3 lados. 040 lado, sera mantido em toda sua extensias, por uma linha de cimbina. mentos e ficara a espera da estrutura res tante (2Ifase), com a qual se solidarizara" nao sofrendo o confunto, no final, qualquer solucaso de continuidade.

Estes cimbramentos ja passam a ser, a 72 linha de cimbramentos para a execuctás da estrutura, ha $Z$ a fase. A laje superior (jogos). que tem um balanco de $3,60 \mathrm{~m}$, terá $a$ poios de pilares e cortinas de concreto, de acoindo com a distribuiaro da placta teirea.

Para protecas da construcáo existente, devante as obras da 1-afase, será feita uma cartina tempo rária de sub-muracáo, para as escava cóes necessánias.

AREAS

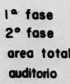
$\begin{array}{r}868.50 \mathrm{~m}^{2} \\ 963.50 \mathrm{~m}^{2} \\ \hline 1.852 .00 \mathrm{~m}^{2} \\ 220.00 \mathrm{~m}^{2} \\ \hline\end{array}$

areas $2^{\circ}$ fase
areo total
auditorio $2.07200 \mathrm{m2}$ 


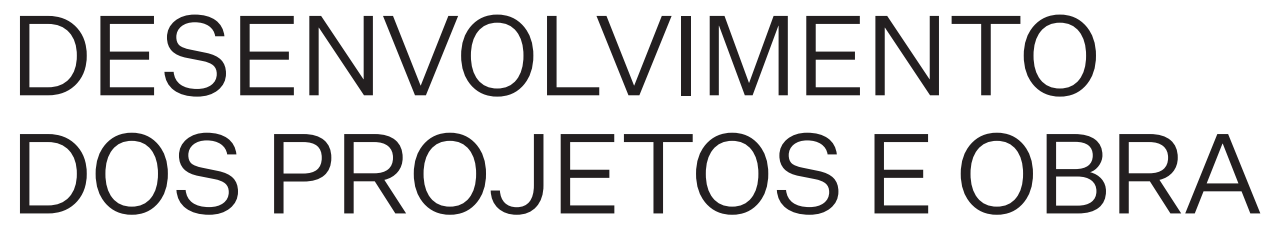

\section{CONTRATO}

O contrato de pagamento de direitos autorais é assinado no dia 16 de dezembro de 1964, dois dias antes da previsão para o encerramento do concurso. Nele estão descritas as condições de contratação do projeto completo de arquitetura, contendo plantas, cortes, elevações em escala 1:50, desenhos de detalhes em escala de $1: 1$ a 1:20, memoriais descritivos e quantitativos dos materiais a serem empregados no projeto, exceto material básico (tijolos, areia, cal, cimento, pedra, etc.), além dos projetos de aprovação frente aos poderes competentes.

Os projetos e serviços técnicos complementares de sondagem, cálculo estrutural, cálculo das instalações hidráulicas e sanitárias, cálculo das instalações elétricas, telefônicas e das instalações especiais, paisagismo, seriam contratados pelo clube, ficando o arquiteto responsável pelo perfeito entrosamento entre tais fatores e o projeto arquitetônico.

Os prazos estabeleciam a entrega dos dados necessários à aprovação dos poderes competentes em 10 de janeiro de 1965 e o projeto definitivo com plantas, corte e elevações em 31 de janeiro de 1965 e desenhos de detalhes e memoriais em 28 de fevereiro de 1965.

$O$ valor correspondente a contratação do arquiteto ficou estipulado em $\mathrm{Cr} \$ 14$ milhões ( $\mathrm{R} \$ 364.999,26$ corrigidos pelo IGPM-DI da FGV em dezembro de 2019).

Ainda previa o comprometimento do clube em executar o projeto de acordo com os desenhos e memoriais apresentados, que uma vez entregue não poderia sofrer modificações, cabendo ao arquiteto o direito de vistoriar periodicamente a obra. Outra cláusula previa o fornecimento de todos os desenhos originais.

\section{PROJETOS EXECUTIVOS}

A pesquisa obteve acesso aos projetos executivos originais sob guarda do clube, porém não foi permitida a digitalização deste conjunto. $\mathrm{O}$ anexo 1 a este documento apresenta uma tabela com as folhas, tipos de desenhos e pastas em que se encontram os projetos.

As equipes de profissionais que desenvolveram os projetos executivos e construção do edifício-sede, entre os anos de 1965 e 1970, são:

\section{Arquitetura: Fabio Penteado, Alfredo Paesani e Teru Tamaki \\ Interiores: Arq. Cesar Luiz Pires de Mello \\ Serviços: Francis Laugery \\ Cálculo estrutural: Oswaldo de Moura Abreu, Waldemar Tietz e Nelson de Barros Camargo, Sociedade Civil Ltda.}

Hidráulica e Elétrica: Escritório Técnico Heinrich Zwilling e Companhia Ltda.

Acústica e sonorização: arq. Igor Sresnewsky Jardins: Walter Doening

Estrutura executada pela Construtora Dumez

Estudo de cores: Antonio Maluf

Construtora: Moraes Dantas S.A.

O projeto executivo, ao contrário do que previa o edital do concurso, não foi desmembrado em duas etapas. O projeto se manteve muito próximo à segunda versão apresentada, com a inclusão do auditório, com o número de assentos reduzidos a 154 lugares e a implantação do térreo com a área de jardim e vagas justapostas à rua Canadá. Os brises metálicos articuláveis receberam fechamento em lonas de cor laranja, substituindo as venezianas metálicas anteriormente propostas.

A definição do espaço sob a cobertura do edifício, é configurada por três patamares, intercalados por dois tramos de escadas coincidentes com intercolúnios 
laterais, que interligam a área de entrada do clube na cota $+0,90 \mathrm{~m}$ à piscina na cota $+3,685 \mathrm{~m}$. $\mathrm{O}$ volume entre a cobertura e o piso dos ambientes sociais enfatiza a continuidade espacial, com variações de pés-direitos, e é iluminado pelas aberturas zenitais e fachadas de vidros, protegidas pelos brises. Estrategicamente implantada entre os patamares, uma peça-tronco cone, onde se localiza a cozinha, organiza os ambientes de estar, restaurante e bar à sua volta e interliga a área social ao setor de serviços no subsolo, onde também estão localizados o auditório, o salão de jogos, assim como os sanitários para uso dos sócios.

O acesso dos sócios está localizado no primeiro patamar, na cota $+0,90 \mathrm{~m}$ em relação à rua, onde também está situada uma sala de leitura, a secretaria e as áreas administrativas do clube. A entrada possui dimensões restritas e pé-direito de $2,50 \mathrm{~m}$, tornando-se um local de passagem controlada e constrangida. Esta área possui dois tramos de escadas, sendo um descendente, que se articula ao subsolo onde estão localizados o salão de eventos e auditório para 154 lugares, permitindo o ingresso de pessoas externas sem a necessidade de circular pelas demais áreas do edifício; e outro tramo ascendente, que se articula com o segundo patamar.

Localizado na cota $+2,425 \mathrm{~m}$, o segundo patamar possuí 9,75m de comprimento e um pé direito elevado, com 3,675m de altura, e abriga uma ampla sala de estar, área de mesas do restaurante e acesso à copa interna ao volume em tronco de cone. Este patamar se interliga ao mezanino, sobre a área da entrada, aos banheiros masculino e feminino, aos jardins laterais externos e ao terceiro patamar localizado na cota $+3,325 \mathrm{~m}$.

O terceiro patamar possui $8,55 \mathrm{~m}$ de comprimento, pé-direito de $3,375 \mathrm{~m}$, nele está localizado o bar e outra ampla sala de estar, que se comunicam diretamente com a varanda coberta, onde estão as mesas externas para atendimento do restaurante junto à piscina, situada na na cota 3,685 . O mezanino para a prática de bridge está na cota $3,90 \mathrm{~m}$, sobre o patamar de entrada do nível próximo ao da piscina, com pé-direito reduzido de 2,20m; possui também um bar e sanitários próprios. Sua privacidade é resguardada pelo conjunto de brises e por painéis verticais móveis, que podem ser removidos nos momentos de festas e eventos de grande público.

$O$ ingresso de funcionários, materiais e fluxo de lixo é realizado pela lateral do edifício, sem contato visual com as áreas sociais do clube. $\mathrm{O}$ acesso das áreas de serviços ocorre sob o edifício a partir da cota +98,52m, em relação à rua, onde está localizada a portaria de serviços, banheiro e vestiário de funcionários, despensa, cozinha de primeiro preparo, adega e depósitos. Da cozinha de primeiro preparo é possível acessar em nível o atendimento ao salão de eventos sociais ou ascender por escada ao volume tronco de cone, na cota $+2,425 \mathrm{~m}$, onde está a cozinha de cocção e o acesso ao salão para o atendimento do restaurante e bar. 


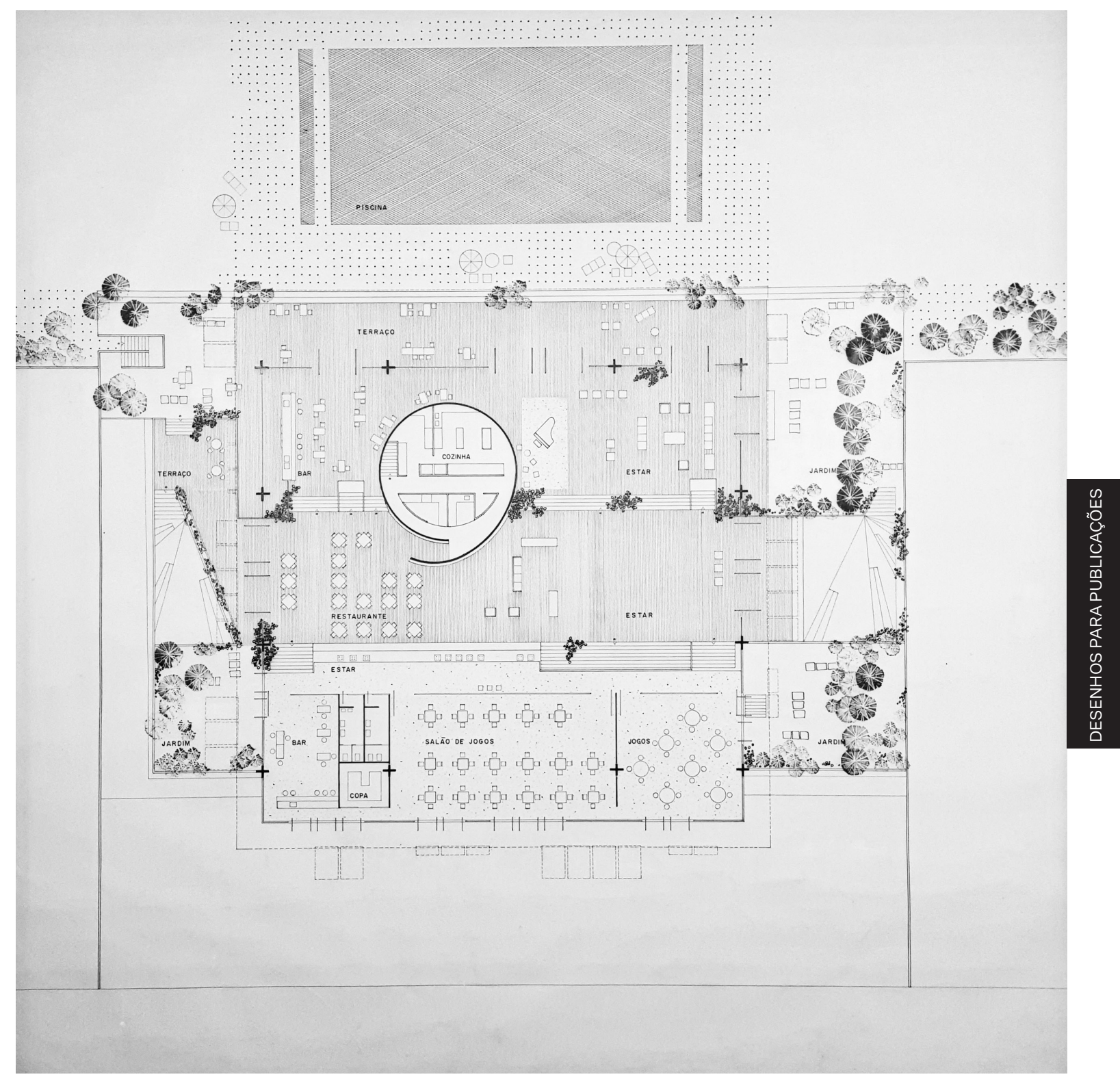

$94 \uparrow$ Planta Térreo e Mezanino - Desenhos para Publicações, São Paulo, 1965.

Fonte: Acervo do Arquivo Fábio Penteado. 


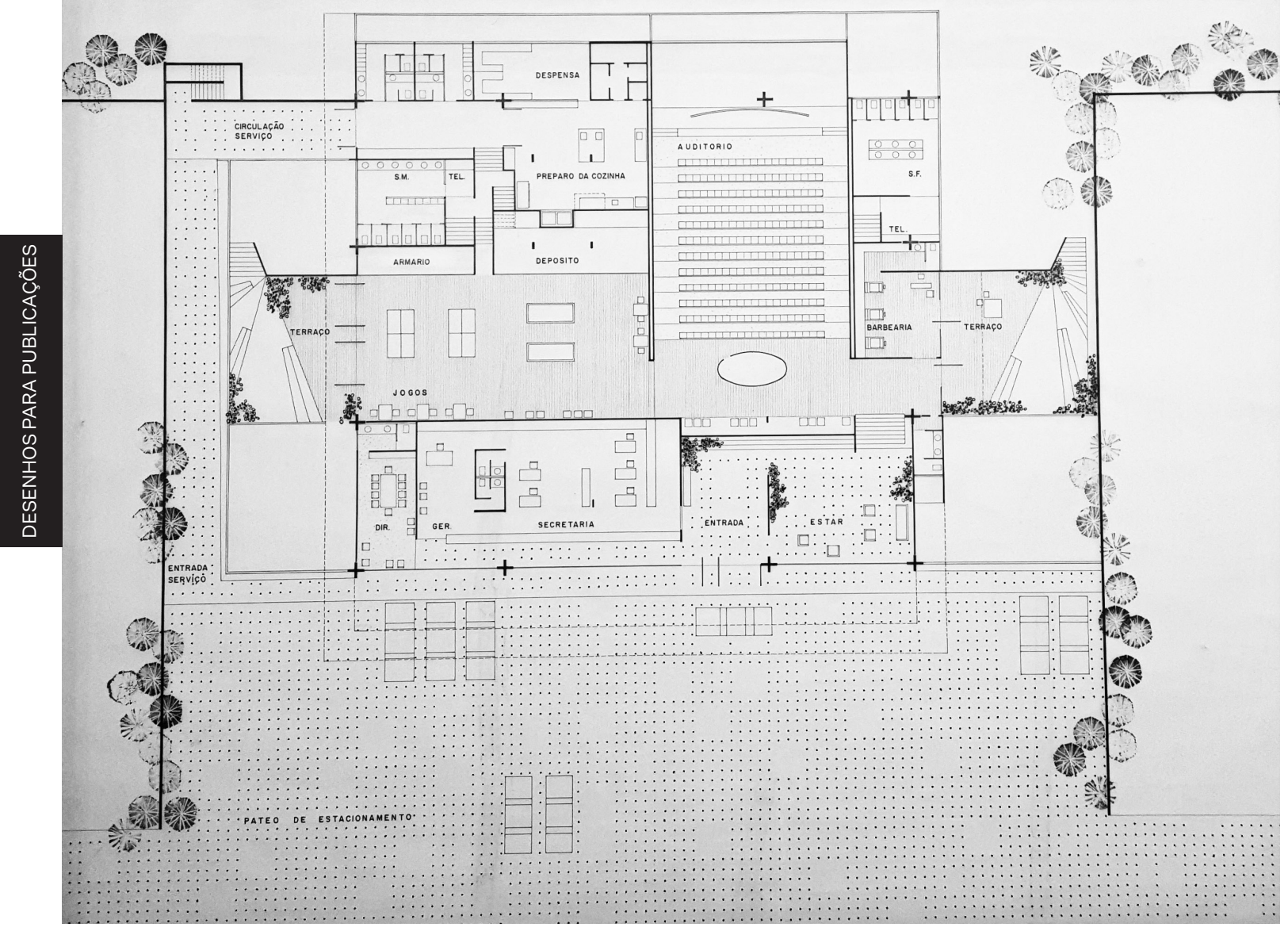

$95 \uparrow$ Térreo e Subsolo - Desenhos para Publicações, São Paulo, 1965.

Fonte: Acervo do Arquivo Fábio Penteado. 

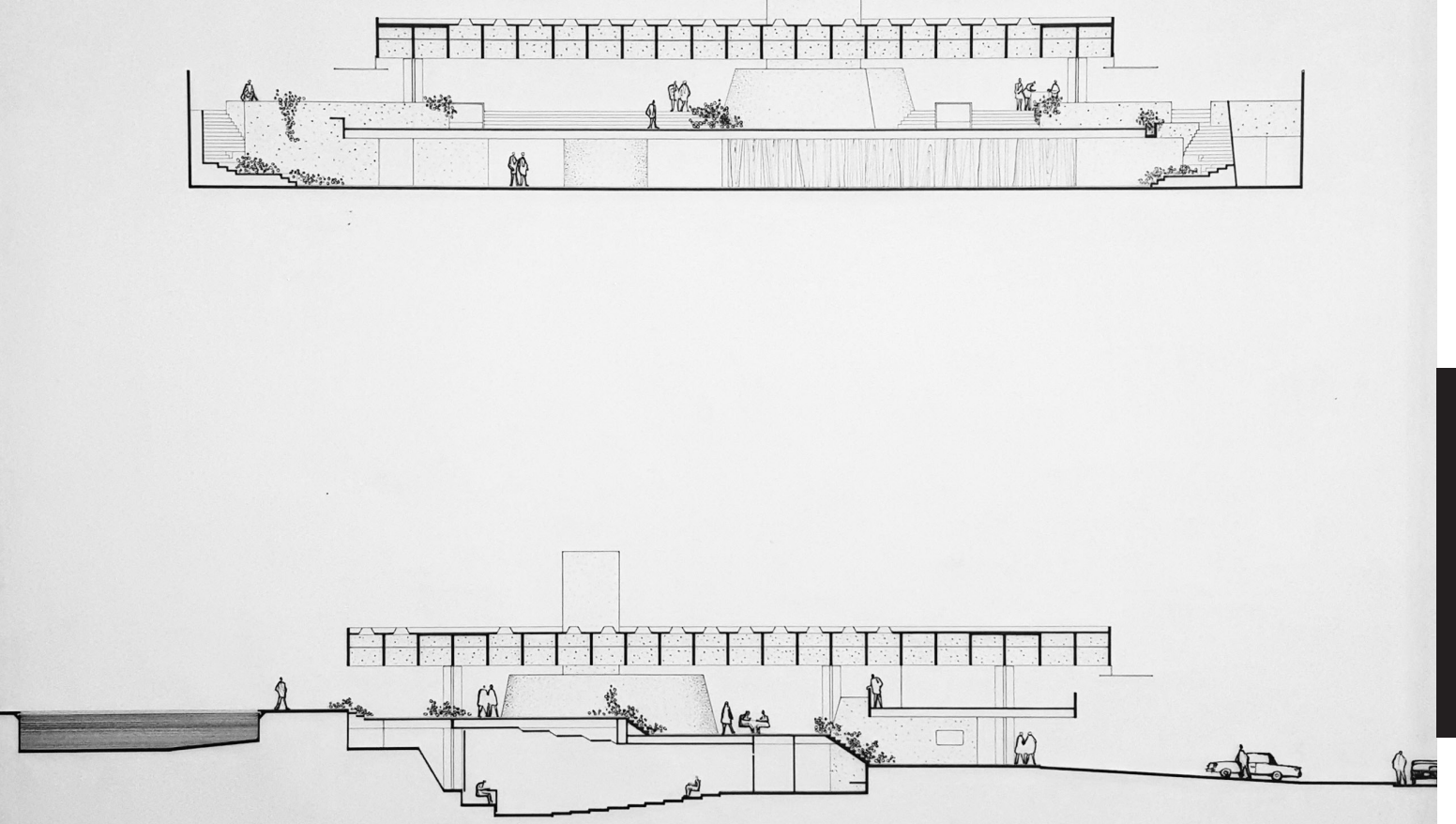

$96 \uparrow$ Cortes - Desenhos para Publicações, São Paulo, 1965.

Fonte: Acervo do Arquivo Fábio Penteado. 

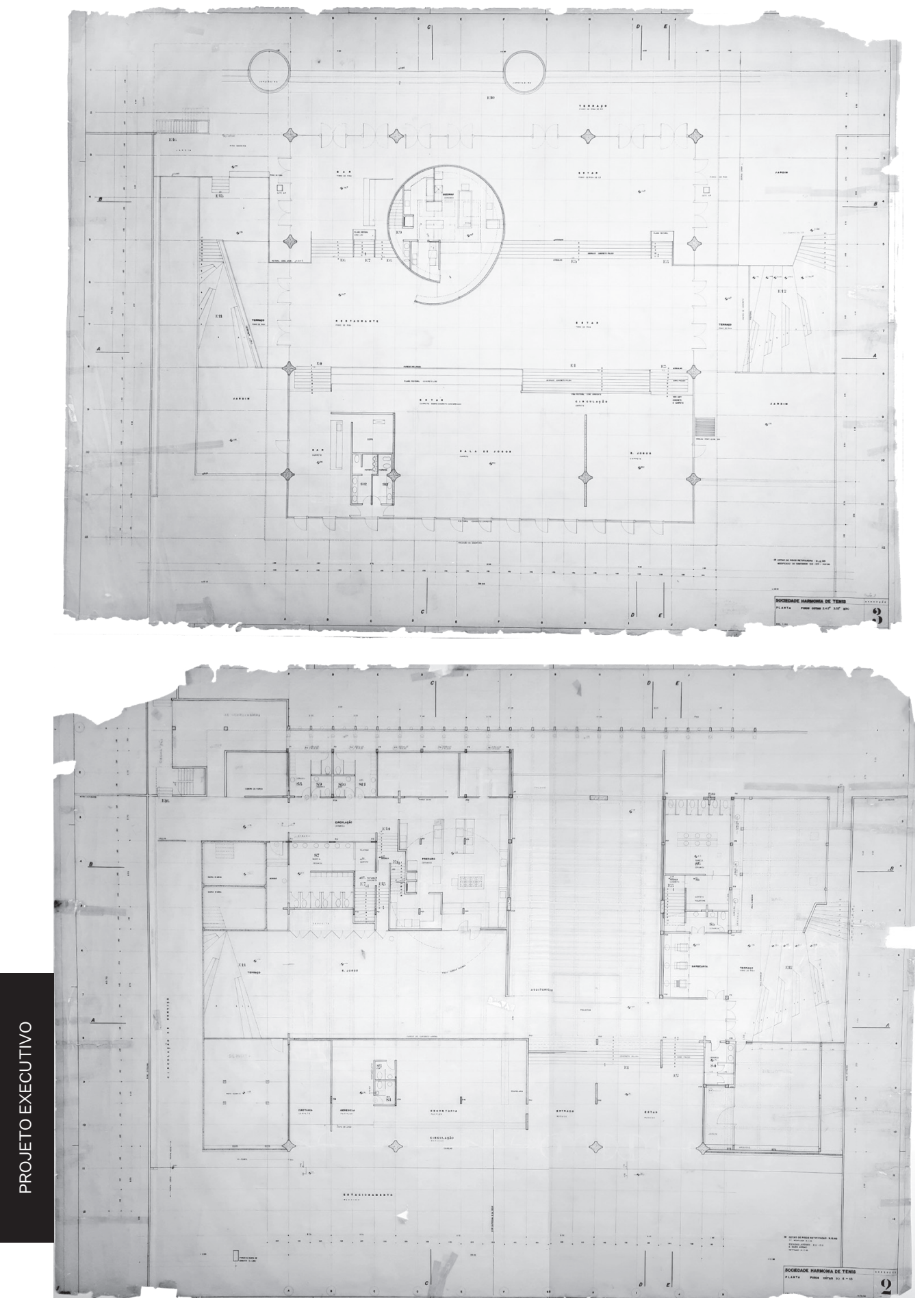

Figura 97 - Planta Térreo e Mezanino - Projeto Executivo, São Paulo, 1965.

Fonte: Acervo do Arquivo Fábio Penteado.
Figura 98 - Planta Térreo e Subsolo - Projeto

Executivo, São Paulo, 1965.

Fonte: Acervo do Arquivo Fábio Penteado. 

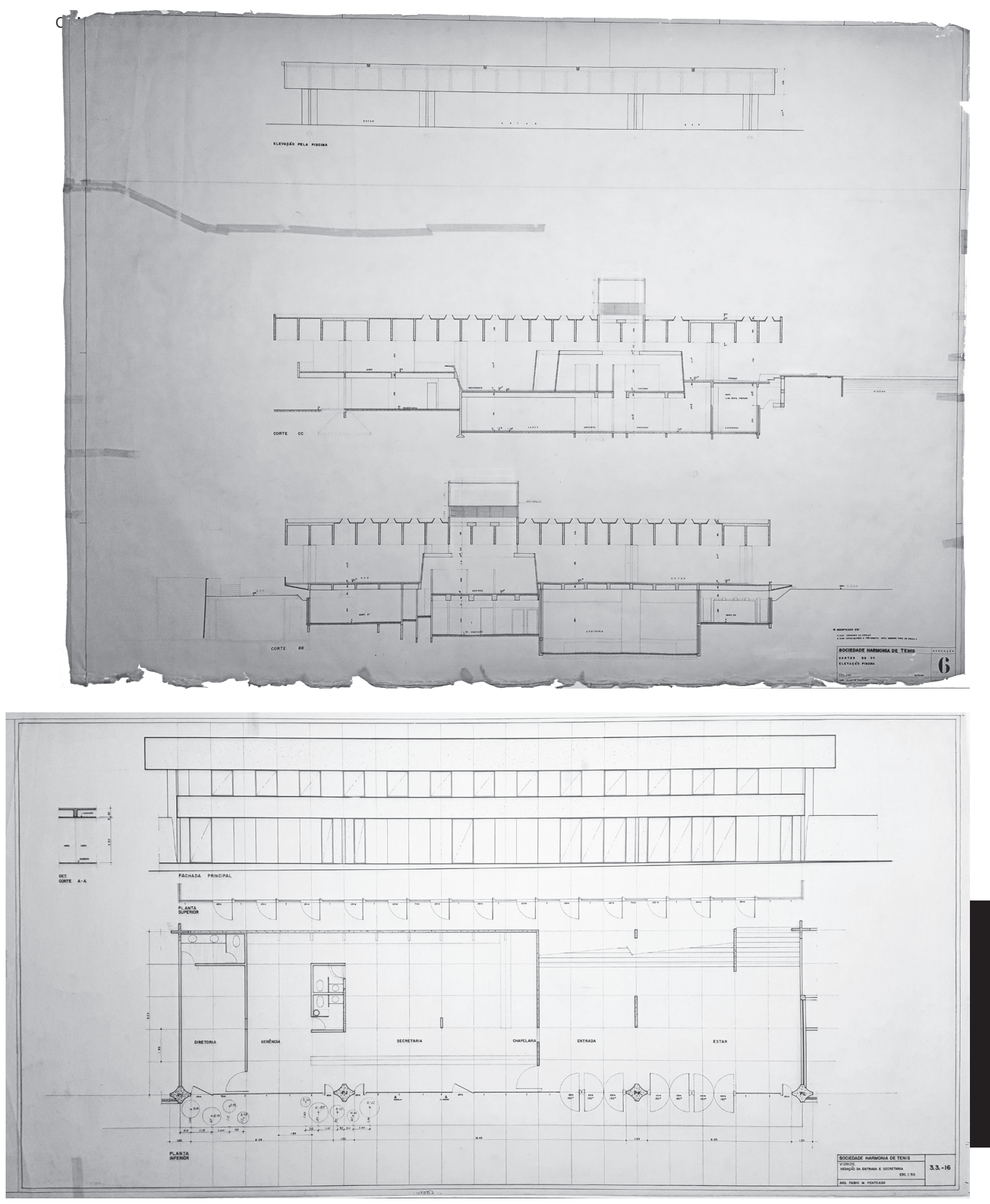

$99 \uparrow$ Cortes - Projeto Executivo, São Paulo, 1965. Fonte: Acervo do Arquivo Fábio Penteado.
$100 \uparrow$ Vedação da entrada e Secretaria - Projeto Executivo, São Paulo, 1965.

Fonte: Acervo do Arquivo Fábio Penteado. 

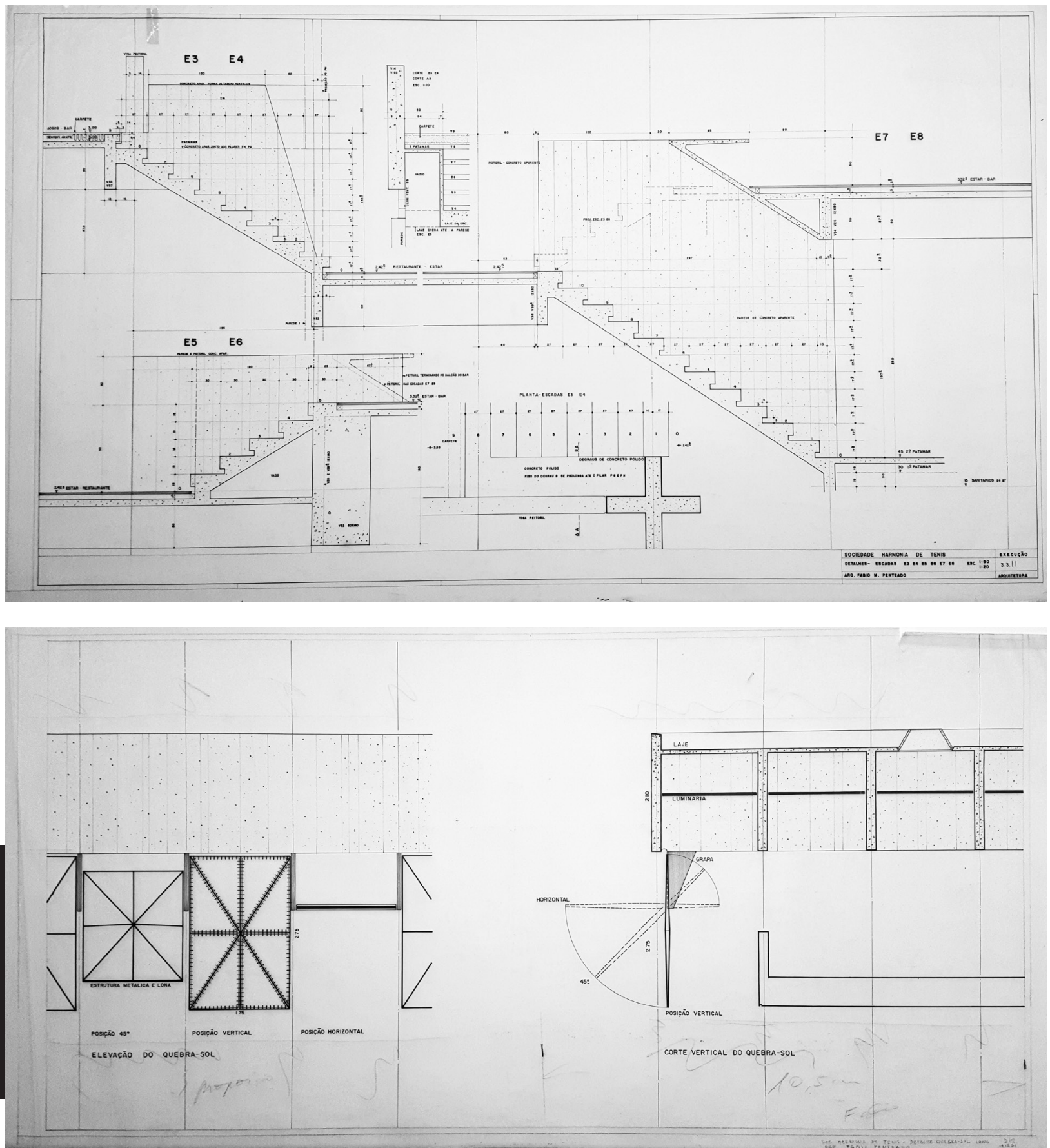

$101 \uparrow$ Detalhes Escadas - Projeto Executivo, São Paulo, 1965. Fonte: Acervo do Arquivo Fábio Penteado.
$102 \uparrow$ Brises de Fechamento - Projeto Executivo, São Paulo, 1965. Fonte: Acervo do Arquivo Fábio Penteado. 


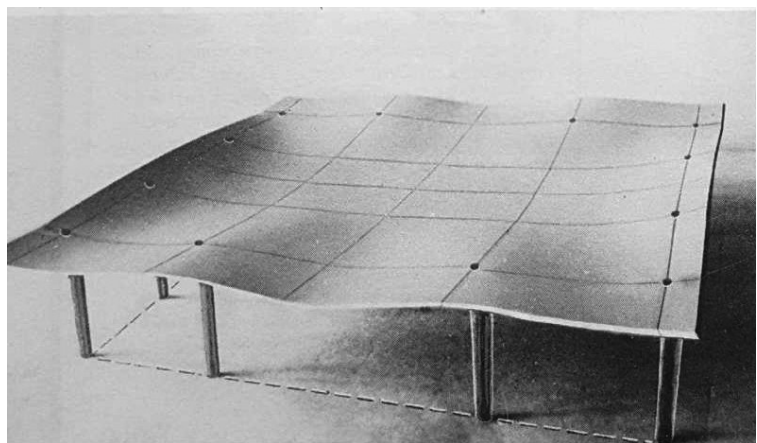

ESTRUTURA

A estrutura definitiva do edifício é toda projetada em concreto armado aparente. A cobertura é uma laje plana tipo grelha e possui $39,03 \mathrm{~m}$ de frente por $40,88 \mathrm{~m}$ de profundidade, conformando uma área de $1595 \mathrm{~m} 2 \mathrm{sem}$ apoios centrais. A partir de uma malha ortogonal $1,85 \mathrm{~m}$ $\mathrm{x} 1,85 \mathrm{~m}$ as vigas de $1,80 \mathrm{~m}$ de altura e $18 \mathrm{~cm}$ de espessura estão apoiadas em 12 pilares, de seção cruciforme de $1,20 \mathrm{~m} \times 1,20 \mathrm{~m}$, periféricos recuados em relação ao perímetro externo. A frente totaliza 21 módulos cadenciados pelo pilares no ritmo de 1/5/9/5/1 igualmente dispostos nos fundos. As laterais totalizam 22 módulos cadenciados pelo pilares no ritmo de $3 / 5 / 6 / 5 / 3$.

O vão livre longitudinal contém 21 módulos $(38,85 \mathrm{~m})$ e os balanços, no mesmo sentido, possuem 3 módulos (5,55m). O vão livre transversal é composto por 19 módulos $(35,15 \mathrm{~m})$ e os balanços por 1 módulo $(1,85)$.
O pré-dimensionamento da cobertura para o concurso foi realizado a partir da hipótese de uma grelha livremente apoiada na periferia, permitindo aos calculistas a utilização de tabelas elaboradas para este fim. Posteriormente um novo cálculo foi realizado reorganizando seus apoios e elevando a altura das vigas de $1,70 \mathrm{~m}$ para $1,80 \mathrm{~m}$. Conforme afirma a reportagem da revista O Dirigente Construtor de 1966:

Entretanto, em virtude de tratar-se de uma grelha apoiada na periferia somente em quatro pilares de cada lado - no total de 12 apoios - e os balanços nas suas extremidades, os calculistas (...) julgaram necessário elaborar outro cálculo, mais rigoroso, para o dimensionamento definitivo da grelha, baseado nas condições reais de contorno.

A integração das equações diferenciais em derivadas parciais de quarta ordem com condições de contorno definidas, para o cálculo das tensões na placas, representa um dos mais difíceis problemas da teoria da elasticidade, e apenas em restrito número de casos os calculistas tem chegado a esta solução. Para solucionar o problema em pauta foram aplicados os métodos aproximados propostos por Rubenov e Galerkin, baseado no princípio dos deslocamentos virtuais.

(...) Os dados obtidos com o emprego desse método permitiram dimensionar a cobertura em grelha com mais precisão, resultando, dessa forma, em maior segurança e economia. ( O Dirigente Construtor, 1996, p. 14)

A reportagem realizada no período de obras do edifício informa ainda que "o grau de exatidão obtido na solução dos problemas pelo método de cálculo de variação depende principalmente da exatidão da construção".

Os 12 pilares de seção cruciforme, com $1,20 \mathrm{~m}$ $\mathrm{x} 1,20 \mathrm{~m}$, possuem suas arestas internas abauladas e apoiam apenas em seus centros as lajes maciça (sala de jogos) e nervurada (cobertura). Esta solução tornou a cobertura visualmente afastada em relação ao perímetro do pilar, contribuindo para a leveza visual do conjunto estrutural e remete a proposta de Paulo Mendes da Rocha para as bases dos pilares do projeto do Ginásio do Paulistano e ao encontro entre a cobertura e os pilares externos do edifício da FAU-USP (1961) de Vilanova Artigas:

$103 \uparrow$ Modelo Reduzido para o Cálculo Estrutural Fonte: Revista O Dirigente Construtor, 1966, p. 14. 


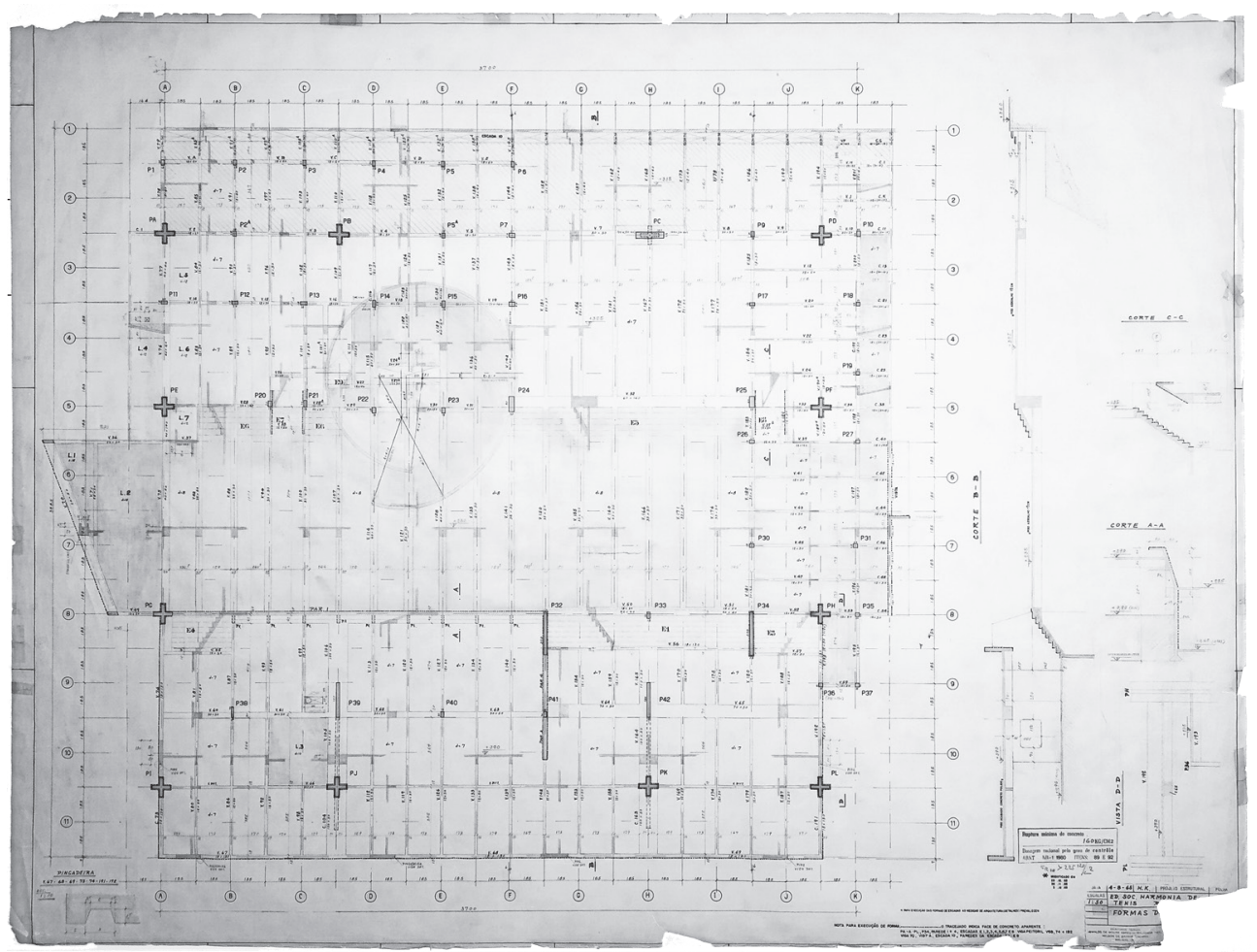

$104 \uparrow$ Planta de Forma Subsolo - Projeto Executivo, São Paulo, 1965.

Fonte: Acervo do Arquivo Fábio Penteado. 
Procuro o valor da força da gravidade, não pelos processos de fazer coisas fininhas, umas atrás das outras, de modo que o leve seja leve por ser leve. O que me encanta é usar formas pesadas e chegar perto da terra e, dialeticamente, negá-las. (ARTIGAS, 2004, p. 225)

Para o apoio do mezanino, foram previstos pilares de $18 \mathrm{~cm}$ de espessura com tamanhos variados, organizados de acordo com a modulação das alvenarias e ambientes propostos para a cota $+0,90 \mathrm{~m}$. O subsolo possui uma parede cortina, junto ao desnível da $+0,90 \mathrm{~m}$, muros de arrimos, ao fundo e laterais, além de 23 pilares, de dimensões variadas, distribuídos para sustentar as lajes da área social. Os apoios estão concentrados nas áreas compartimentadas, liberando a área auditório e salão de eventos.

\section{ÁGUAS PLUVIAIS}

Para o escoamento das águas pluviais da cobertura a equipe optou por reduzir ao mínimo os tubos de descidas evitando a interferência destes nas áreas internas. $\mathrm{Na}$ etapa de anteprojeto, foram previstos quatro tubos posicionados nos beirais laterais do edifício. No projeto

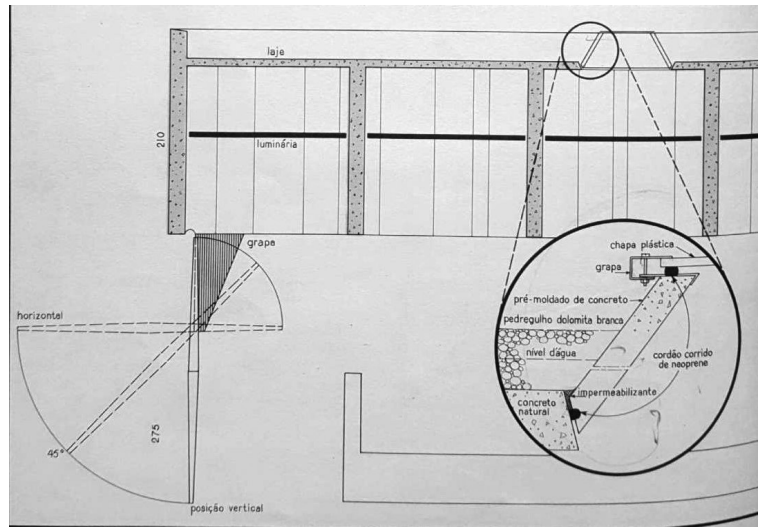

definitivo, além da previsão de uma concretagem estanque da cobertura, a precipitação é absorvida pela área de pedregulhos sobre a laje de cobertura em forma de piscina, que evaporam naturalmente. Para as chuvas excessivas, foram instalados apenas dois tubos de descida com $30 \mathrm{~cm}$ de diâmetro cada nos beirais laterais; em caso de mau funcionamento do sistema, 16 gárgulas distribuídas nas empenas, quatro em cada uma, extravasam essas águas.

\section{ILUMINAÇÃO}

Para a iluminação diurna foram instalados entre as nervuras da cobertura aproximadamente 230 domos de pexiglas, com aproximadamente $45 \mathrm{~cm} \mathrm{x} 45 \mathrm{~cm}$ de abertura, que funcionam em conjunto com as aberturas dos planos de vidro temperado nos fechamentos verticais. Um estudo luminotécnico foi desenvolvido pela empresa francesa Clemenceau, a qual apresentou uma solução para manter a mesma qualidade lumínica diurna nos horários noturnos. O projeto não foi implementado pelo clube, conforme afirmou Penteado:

E por cima entra essa luz, conforme passa o dia muda esse ambiente. Mas à noite fica triste, porque faltou uma iluminação adequada. Eu fiz um estudo com o melhor escritório de luminotécnica na França, mas o Harmonia na época não quis pagar o projeto. (GIROTO, 2013, p. 450)

A proposta luminotécnica foi minuciosamente descrita na revista O Dirigente Construtor:

À noite a variação dos efeitos de luz se processará através de reostatos, dispositivos habitualmente utilizados em iluminação teatral, adaptados aos equipamentos de luz artificial. Será utilizada luz fluorescente com uma intensidade de 400 lux.

Em cada abertura serão dispostas 8 lâmpadas de 1,20m de comprimento, com 40 watts cada, duas a duas, formando quadrado. A luz fluorescente foi escolhida por apresentar menor consumo de energia - de 4 a 5 vezes menos que ao da luz incandescente - e maior durabilidade das lâmpadas - de aproximadamente 7.500 horas contra mais ou menos 2.000 horas para as incandescentes, já que as dimensões dos vãos não permitiriam o emprego de luz de catódio fria - neon - que se apresenta mais econômica e é de maior durabilidade. 
A iluminação demasiado crua das lâmpadas fluorescentes será corrigida por meio de difusores em placas de PVC, coloridos, se possível em tom de carne, o que proporcionará tonalidade mais agradável à iluminação, com apenas pequena perda de intensidade. Esta deverá ser talvez a primeira realização nesse sentido entre nós, sendo que nos Estados Unidos já existem no comércio lâmpadas fluorescentes cujos envoltório são de cor amarelada, com o mesmo objetivo.

Esta iluminação será regulada de acordo com os vários ambientes e a necessidade de ampliar ou restringir os diversos setores, em decorrência do maior ou menor número de pessoas nas dependências do clube. Controles eletrônicos de comando manual, localizados junto aos quadros gerais governarão a iluminação das diversas seções, permitindo diminuição da intensidade da iluminação fluorescente, sem que comece a 'piscar'. (O Dirigente Construtor, 1966, p. 14)

\section{ACÚSTICA}

O projeto de acústica foi desenvolvido pelo arquiteto Igor Sresnewsky, (1913-1996) formado em 1939 na primeira turma de arquitetos do curso de engenharia do Mackenzie, ao lado de Miguel Forte (1915-2002).

Os estudos de acústicas foram especialmente dedicados a dois aspectos: o conforto acústico sob a grande cobertura e a audibilidade do auditório. Em reportagem da revista O Dirigente Construtor, foram levantados os principais desafios encontrados sob a cobertura:

O volume interno total, de cerca de 6 mil m3, autorizava uma previsão de 3 a 5 segundos de tempo de reverberação, dependendo da quantidade de pessoas no ambiente, aberturas para o exterior, móveis, tapeçarias etc.

Um estudo prévio do projeto sob o ponto de vista do conforto acústico indicava três pontos:

Reverberação excessiva;

Possibilidade pequena de formação de ecos devido à estrutura central que contém a cozinha, difundindo o som direto e as reflexões;

Impedimento bastante forte à propagação normal do som, imposto pela estrutura de cobertura, em caixões profundos $-1,75 \mathrm{~m}$. (O dirigente construtor, 1966, p.16)
Para solucionar o problema, Igor Sresnewsky desenvolveu, com a equipe de estruturas, um estudo que impediria a propagação do som através da instalação de ressonadores sintonizados fundidos junto às vigas. Estes componentes permaneceriam visíveis apenas como pequenos orifícios de $1 \mathrm{~cm}$ a $2 \mathrm{~cm}$ de diâmetro, fechados com telas. Também foram propostas luminárias vedadas com plástico perfurado e lã mineral no interior que atuariam em conjunto com os ressonadores.

O projeto acústico para o auditório pretendia eliminar as vibrações dos motores das câmaras frias, exaustor, entre outros, e da entrada de ruídos dos ambientes justapostos: cozinha, salão de jogos e banheiro, além da saída de som do auditório. Foram implantadas paredes duplas no perímetro do auditório com bases e conexões plásticas além do atapetamento do piso e forro refletor de madeira para distribuir o som uniformemente pelo ambiente.

\section{ESTUDO DE CORES}

Penteado encomendou ao artista plástico Antônio Maluf (1926-2005) ao menos dois estudos para a sede do clube. Inicialmente, o artista ficou responsável pelo desenvolvimento de uma proposta para as cores na entrada da sede do clube, no acesso e estacionamento dos automóveis, sobre a qual escreveu:

Seleção e criação de meios que objetivam a integração. Seleção e criação de elementos, tais como nichos, vegetação, cores e sinais que visam a sua integração com a arquitetura e se componham com os automóveis. (Santiago, 2009, p. 108)

Em sua dissertação de mestrado sobre a obra de Antônio Maluf, Santiago (2009) afirma que a pesquisa do artista:

(...) determinaria desde o levantamento de pisos que suportassem o desgaste da intensa circulação, até a utilização dos materiais indicativos que facilitassem o estacionamento e disposição dos automóveis, visando ao máximo de aproveitamento da área, a proteção dos veículos do sol e da chuva e a integração com a paisagem. (2009, SANTIAGO, p. 108) 
O texto de Maluf afirma a intenção do artista e do arquiteto em estabelecerem a integração entre arte e arquitetura superando a ideia decorativa, sobre a qual Penteado demonstraria certa aversão:

Então as madames do Harmonia quando estava ficando pronto fizeram uma revolta, porque não tinha nenhuma parede para pendurar quadros. Eu falei: nos banheiros tem parede. (GIROTO, 2013, p. 450)

A segunda encomenda de Penteado seria o estudo para tornar a grelha de cobertura um grande mural, integrando a estrutura ao estudo de cores de Maluf. Este painel é citado na publicação da revista O Dirigente Construtor:

As cores a serem aplicadas, cujo estudo está a cargo do pintor Antônio Maluf, obedecem a um plano que considera as finalidades típicas do local. Ficarão totalmente integradas ao sistema estrutural, sendo seu sentido tradicional de decoração superado pela ambientação.

Na concepção do arquiteto a cobertura da sede constitui toda a sua arquitetura. A modulação estrutural dessa arquitetura, completa o sr. Antônio Maluf, já foi idealizada como um quadro gigantesco, onde a cor não é simplesmente aquela com que foram pintados os elementos estruturais, mas as que vierem a ser reveladas em cada dia e hora pela intensidade da luz natural ou artificial.

De acordo com as necessidades, os ambientes serão configurados pelas cores através dos controles de iluminação. Esses ambientes poderão ser múltiplos, ao mesmo tempo, como também um único, para um dia de comemoração coletiva. Em um e outro caso é o agrupamento de cores e luzes que os definirá. O número ou tipos de ambientes necessários ao uso do clube poderão variar com o tempo e quantas vezes eles variem sua arquitetura acompanhá-los-á. (O dirigente construtor, 1966, p.18)

Entretanto, estes projetos não foram executados, nem representados através de esboços ou croquis, permanecendo toda a estrutura do concreto aparente até os dias de hoje. O profissional contratado para o projeto de interiores, Arq. Cesar Luiz Pires de Mello (1929-2014), optou pela obra “Bananas”, pintada por Antonio Henrique Amaral (1935-2015) em 1968. “Um

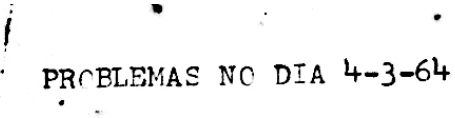

1. FABIC PENTEADC

2. PROVINCIA IMOBILIARIA

3. SIMBCLC PARA FUNDAÇAC BIENAL

4. In ina de Papeis para BCRIS RClCFF

5. N VA PAREDE PARA VILA NCRMANDA

6. Iinha de papeis para ANTCNIC MALUF

7. inarciano

1: De FANIC PENTEADO

$C$ problema é a sua propria formulação.

o Fábio deseja que se apresente o mais

rapidamente, um estudo a cores do que

seria a entrada da SCCIEDADE HARMONIA

de TENIS.

* um trabalho no qual eu mesmo estou

inseguro, pois ainda terla que real-

mente conceituar o seu objetivo utili-

tário e não tenho back-ground para ter

uma concepção formal rapida.

Deverei considerar no desenho, todos os elementos de fachada, e a melhor dispo sição dos automoveis, seja para que se tenha um maximo de aproveitamento da area de estacionamento, seja para que a mesma tenha um novo valor integrando os automoveis na paisagem ou ainda, criando um novo valor com outres elementos que sejam necessarios para isso. $r$ s automoveis ainda deverão ser resguar dados o mais possivel do sol ou da chuv Para a sua boa disposiçăo no local devì räo ser utilizados recursos de comunicação no prprio piso a ser determinado por mim ou outros recursos idem.

trabalho com características distintas da arte concreta desenvolvida por Maluf, inicialmente pensada para o ambiente.” (SANTIAGO, 2009, p. 109).

Segundo o verbete da enciclopédia do Itaú Cultural:

Como metáfora, a banana refere-se tanto à ditadura militar quanto à posição do Brasil no conjunto dos países democráticos, ao "ser" brasileiro no momento do slogan "Brasil, ame-o ou deixe-o", ao mesmo tempo em que retoma uma tradição moderna de representação do caráter nacional que se inicia com a bananeira em Tropical, (1917) de Anita Malfatti, (1889-1964) passando pela pintura A Negra, (1923) de Tarsila do Amaral, (1886-1973) e Bananal, (1927), de Lasar Segall (1891-1957). (Amaral. In: ENCICLOPÉDIA Itaú Cultural de Arte e Cultura Brasileiras. $)^{1}$ 


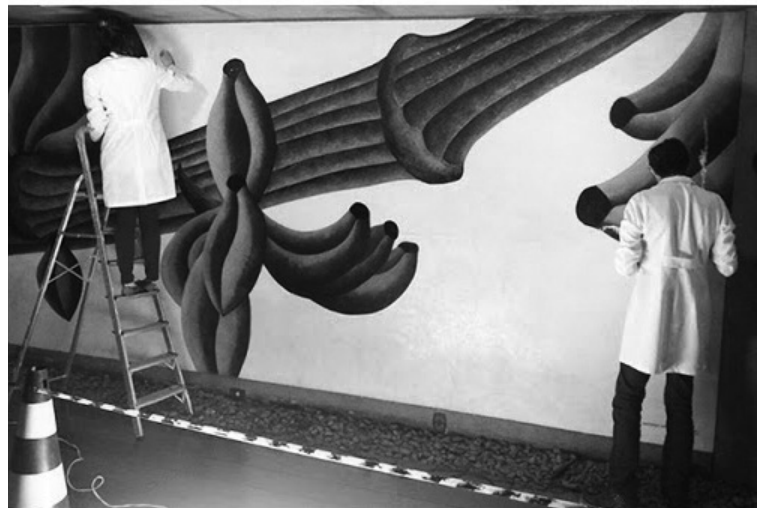

\section{MOBILIÁRIO}

Penteado projetou o conjunto de mobiliário para as áreas de estar. Estes seriam móveis para facilitar a reconfiguração o ambiente. As poltronas do auditório também foram detalhadas a partir de peças verticais de concreto que sustentariam os encostos e assentos estruturados em metal e revestidos em couro. Nenhum destes mobiliários foram executados pelo clube, que optou pela compra de itens de prateleira especificados pelo arquiteto responsável pelo projeto de interiores. 

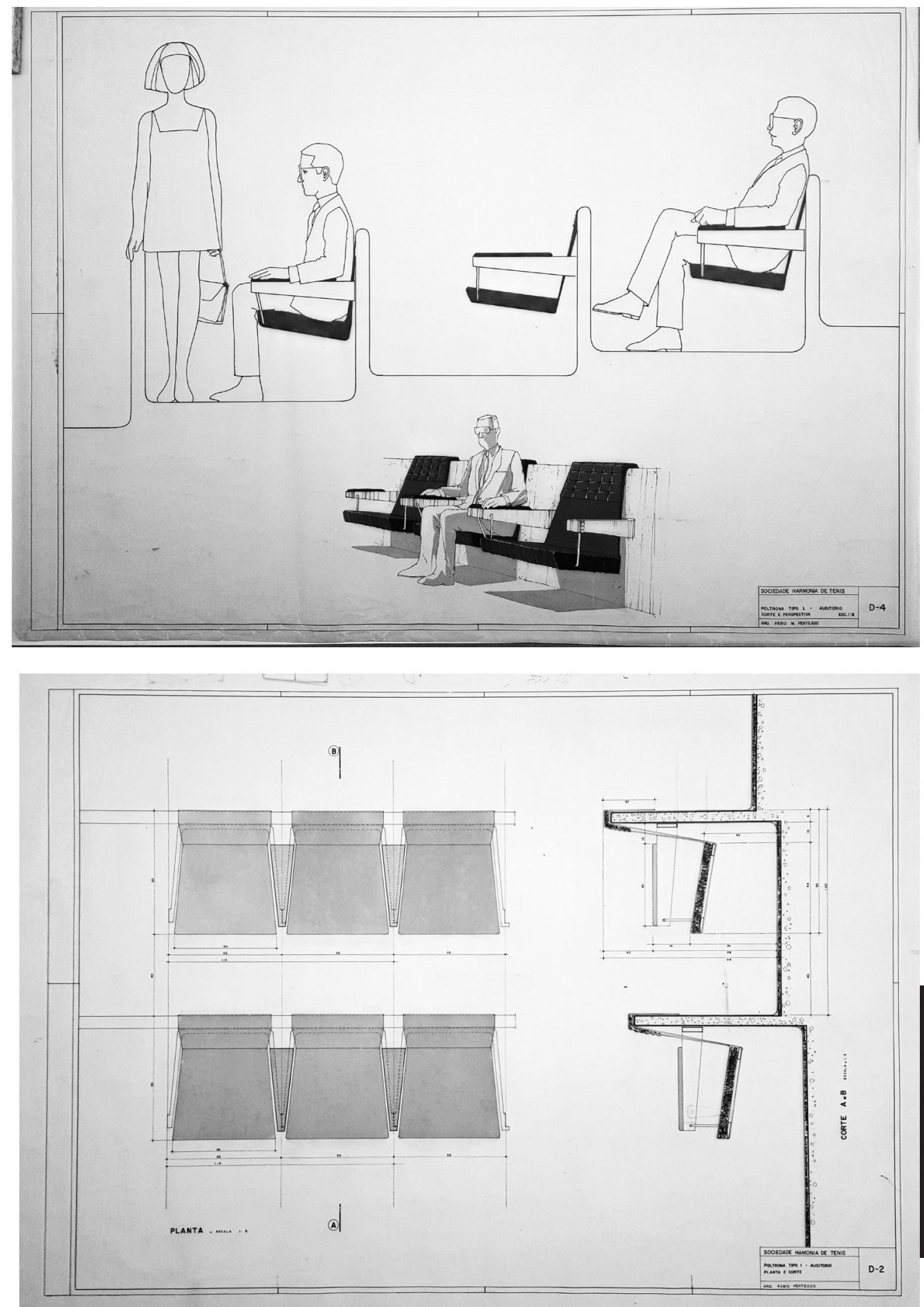

$108 \uparrow$ Perspectiva e Corte, Poltronas do Auditório Projeto Executivo, São Paulo, 1965.

Fonte: Acervo do Arquivo Fábio Penteado.
$109 \uparrow$ Planta e Corte, Poltronas do Auditório - Projeto Executivo, São Paulo, 1965.

Fonte: Acervo do Arquivo Fábio Penteado. 


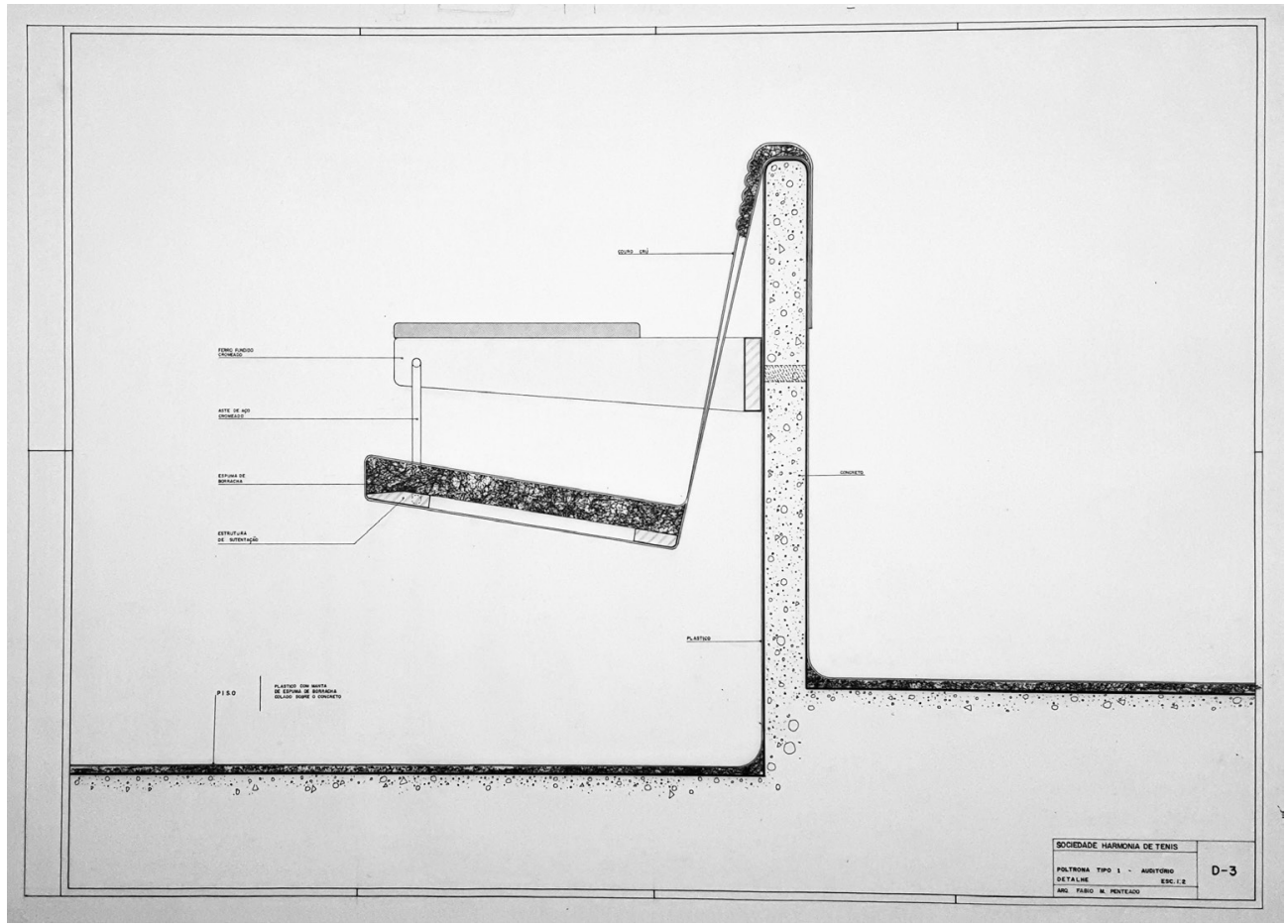

$110 \uparrow$ Corte, Poltronas do Auditório - Projeto

Executivo, São Paulo, 1965.

Fonte: Acervo do Arquivo Fábio Penteado. 


\section{RELAÇÃO COM}

\section{A PAISAGEM}

O bairro do Jardim América está localizado na zona sudoeste de São Paulo, região de privilegiada infra-estrutura urbana, que concentra grande parte dos domicílios da elite econômica paulistana. Implantado entre as cotas $+740 \mathrm{~m}$ e $+745 \mathrm{~m}$ em relação ao nível do mar, o bairro, praticamente plano, está situado a 2 quilômetros de distância do Rio Pinheiros $(\operatorname{cota}+720 \mathrm{~m})$ e da avenida Paulista (cota $+815 \mathrm{~m})$.

As características ambientais previstas no plano original do Jardim América permanecem em boa parte inalteradas até os dias atuais, por efeito da sobreposição de leis e regras estabelecidas pela Cia. City, Prefeitura Municipal de São Paulo e CONDEPHAAT. A sua paisagem se caracteriza pelas vias arborizadas e lotes de dimensões generosas, nos quais estão implantadas edificações isoladas com até dois pavimentos, de uso predominantemente residencial. A avenida Brasil, principal via planejada, é uma das exceções do bairro, com a predominância de comércio e serviços.

O edifício-sede de que estamos tratando está implantado na rua Canadá, a 160 metros da avenida Brasil, e representa o principal acesso social do Harmonia. $\mathrm{O}$ lote de $59 \mathrm{~m}$ de frente por $55 \mathrm{~m}$ de profundidade se interliga às áreas esportivas do clube, instaladas no antigo jardim central da quadra número 42 .

Penteado afirma que:

O Harmonia, de todos os projetos, eu acho que é o mais bem afirmado, porque é um terreno pequeno. Todos os terrenos de volta são de uma residência. A origem do Jardim América, sempre se deixava um espaço grande no meio, aquele sistema inglês, que os moradores usavam. Todos eles foram transformados, menos o Harmonia, que ficou mesmo, e tem um terreno que dá para a rua. A proposta é a seguinte, como o clube não é grande e tinha um programa, para ser colocado em dois mil metros quadrados de área, o Harmonia foi pensado como um espaço único.

(GIROTO, ano 2013, p. 450)

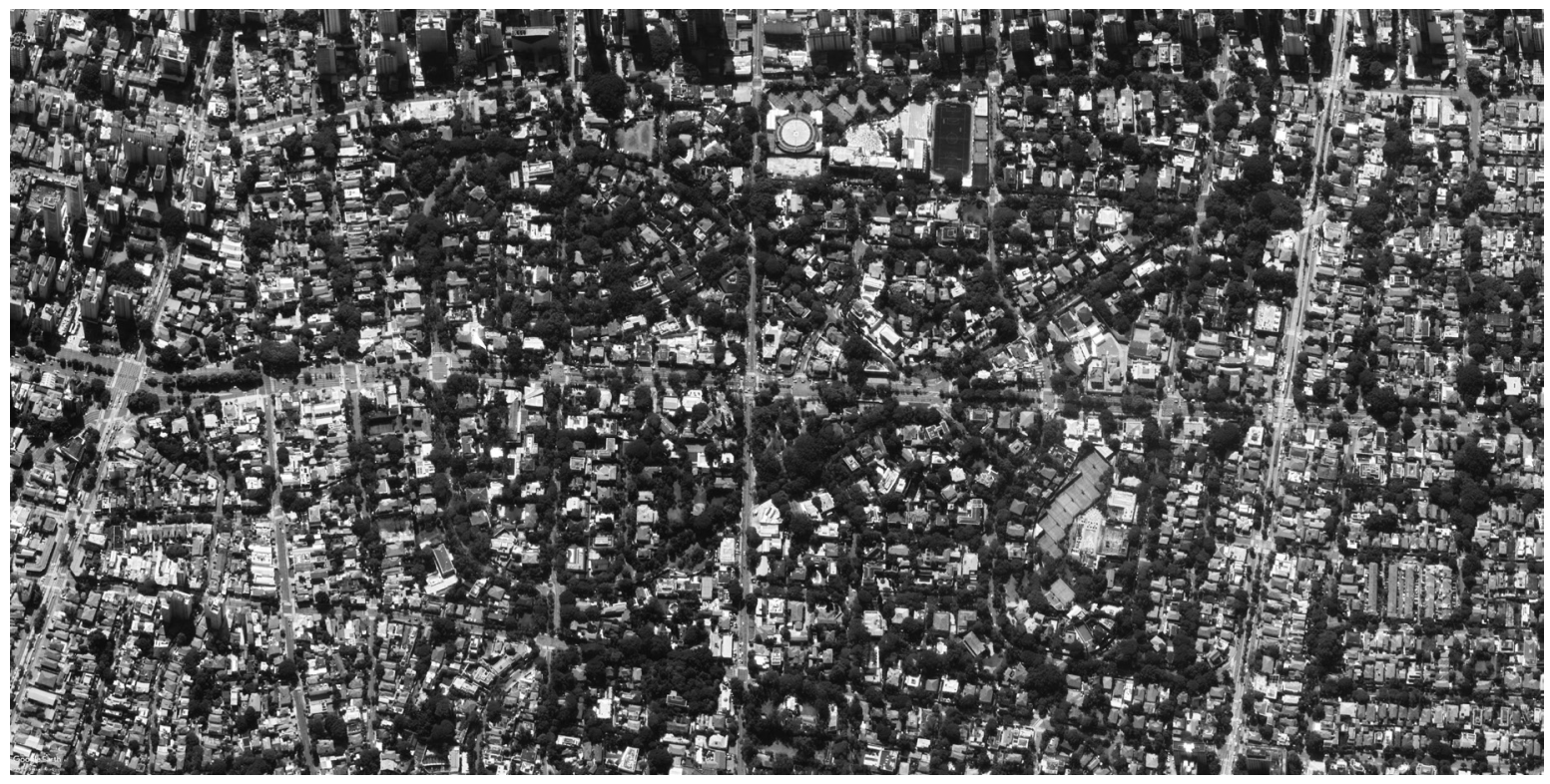

$111 \uparrow$ Imagem de Satélite da Região do Jardim América Fonte: Google Earth, 2019. 


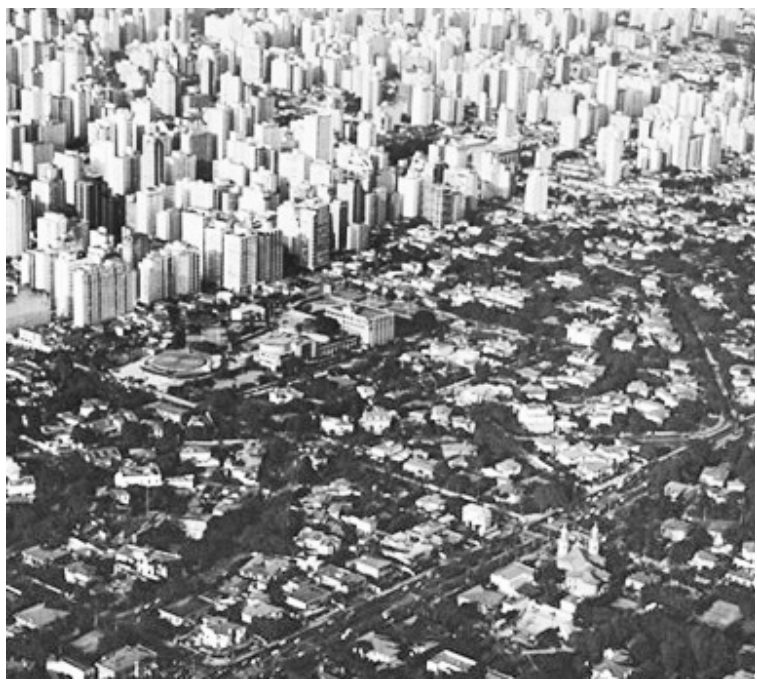

Obedecendo praticamente aos mesmos parâmetros urbanísticos dos demais lotes do bairro, a volumetria do edifício-sede se integra à paisagem da vizinhança, com dois pavimentos acima do solo, recuada das divisas laterais e afastada do alinhamento frontal. A sua distinção se evidencia, principalmente, pela ausência de muros e fechamentos junto ao passeio público e pela concepção moderna da sua arquitetura.

Para atender à prerrogativa da City de delimitar o lote em relação ao passeio público, os arquitetos projetaram um jardim no alinhamento frontal, com uma escada ao centro e rampas suaves nas laterais, que possibilitam o acesso de veículos ao embarque e desembarque coberto dos sócios e área para carga e descarga. Sem dispor de áreas para estacionamentos dentro do clube, foram propostas 13 vagas justapostas à rua Canadá.

A partir da rua é possível visualizar as fachadas laterais e frontal do edifício constituídas por um conjunto sucinto de materiais. No alto, as vigas de concreto armado, com aproximadamente $40 \mathrm{~m}$ de largura e $2,30 \mathrm{~m}$

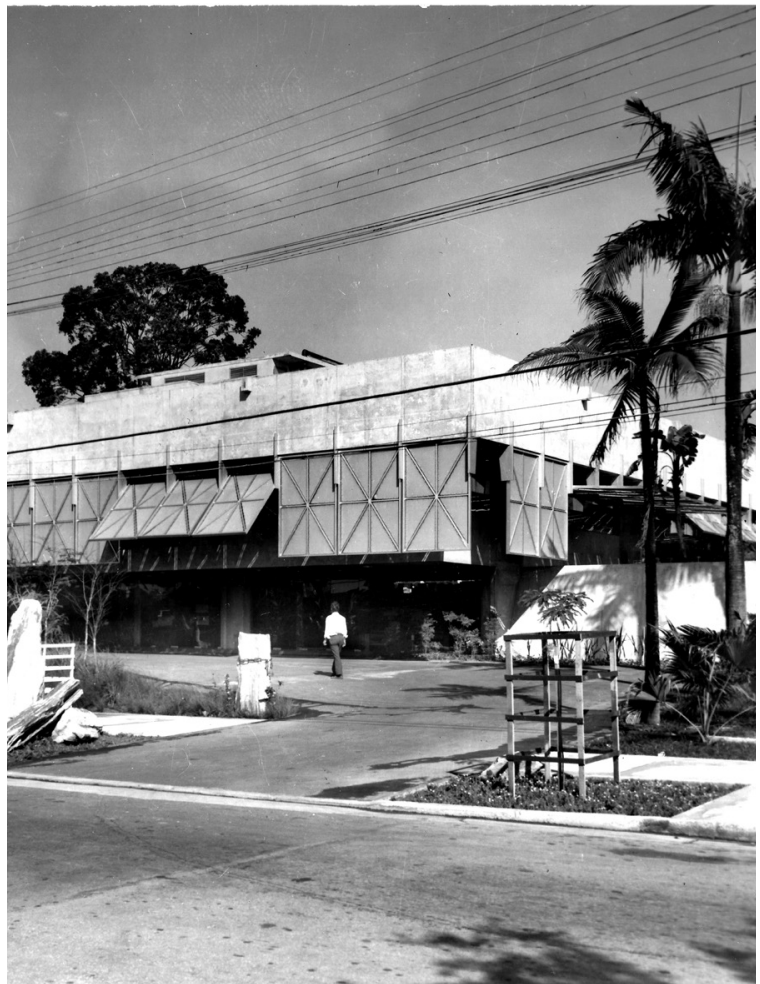

de altura, delimitam o perímetro da cobertura plana em balanço e reforçam a horizontalidade da construção. Nas bases destas vigas estão fixados os conjuntos de brises articulados, que conferem movimento às fachadas, são elementos metálicos com lonas alaranjadas que se destacam do restante do conjunto. No nível do térreo, as vedações são translúcidas, compostas por caixilhos recuados em relação à projeção da cobertura, definindo assim limite entre a área pública e os espaços restritos no interior do edifício.

Sua exterioridade discreta se aninha entre a horizontalidade do bairro silenciosamente, como se não quisesse chamar a atenção mais do que o necessário. Sem a finalidade de atração social, sua dimensão pública e seu valor comunicativo residem dentro da arquitetura, na experiência que o amplo espaço comum sugere. (GIROTO, 2013, p. 212)
$112 \uparrow$ Vista aérea do Jardim América, São Paulo Fonte: Acervo Cia City. ${ }^{3}$
$113 \uparrow$ Macardi, José. Edifício-Sede do Clube Harmonia, 1971. Fonte: Acervo do Arquivo Fábio Penteado. 


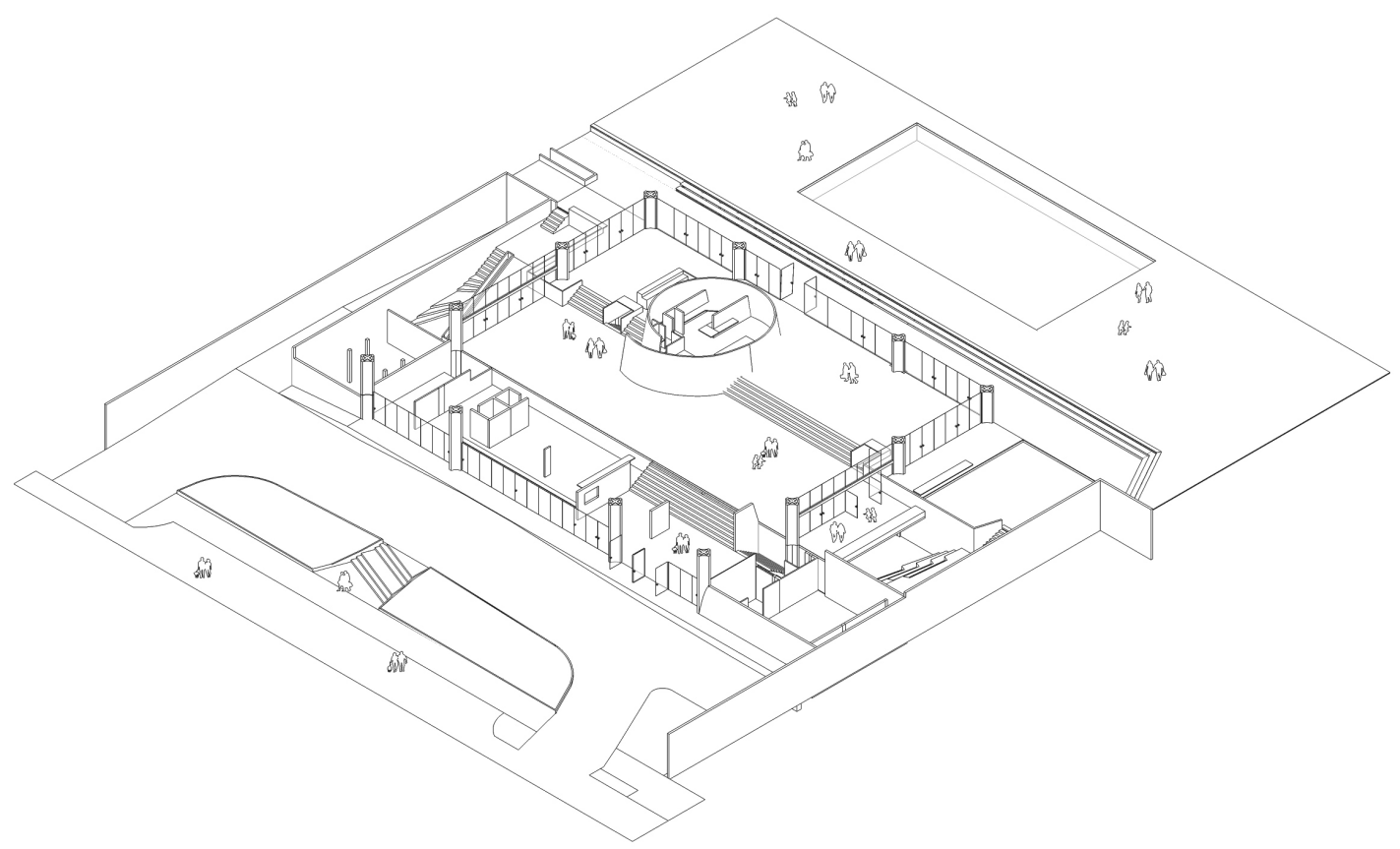

\section{A PRAÇA COBERTA}

A experiência dos espaços sociais do edifício-sede é bastante fluida desde a entrada até chegar à área das piscinas. Seu propósito basilar compreende-se na sequência de ambientes que conformam uma praça implantada em meios-níveis, concebida como um lugar "confortável para duas ou duas mil pessoas" (GIROTO, 2013, p. 215), onde predomina a sensação de continuidade espacial. A passagem de dimensões generosas que conformam o lugar de encontro, e caracteriza também o edifício da FAU-USP, de Artigas, no Harmonia se apresenta como uma praça protegida por sua cobertura luminosa, com visuais desimpedidas que proporcionam a leitura do seu programa social e a perspectivas da paisagem constituída pelos jardins dos recuos laterais e a área de piscina ao fundo.

Penteado afirma que desde o projeto não construído para o Hotel Praia do Peró (1958), sua prática profissional foi pautada pela tentativa de produzir uma arquitetura "de intenções humanísticas de grande beleza." (PENTEADO, 1983, p. 19) Os projetos aqui analisados demonstram a atenção do arquiteto à fruição dos usuários em suas obras, ao passo que rejeita os padrões reproduzidos em outros edifícios com usos similares.

A partir das declarações de Penteado, é possível sugerir que seu projeto é antitético, pois se estabelece a partir da crítica à maioria dos clubes consolidados até aquele período.

Em um depoimento posterior à construção do edifício-sede, Penteado demonstra a sua antipatia ao conceito fundamental dos clubes que pressupõe o isolamento de determinado grupo de pessoas:

O Brasil era o país com o maior número de clubes do mundo - não sei se mudou agora -, o sujeito um pouco mais rico já se separa, para a filha não casar com um sujeito mais pobre. (GIROTO, 2013, p. 450)

$114 \uparrow$ Modelo 3D do Edifício-Sede do Clube Harmonia. Fonte: Material Desenvolvido pelo Autor. 

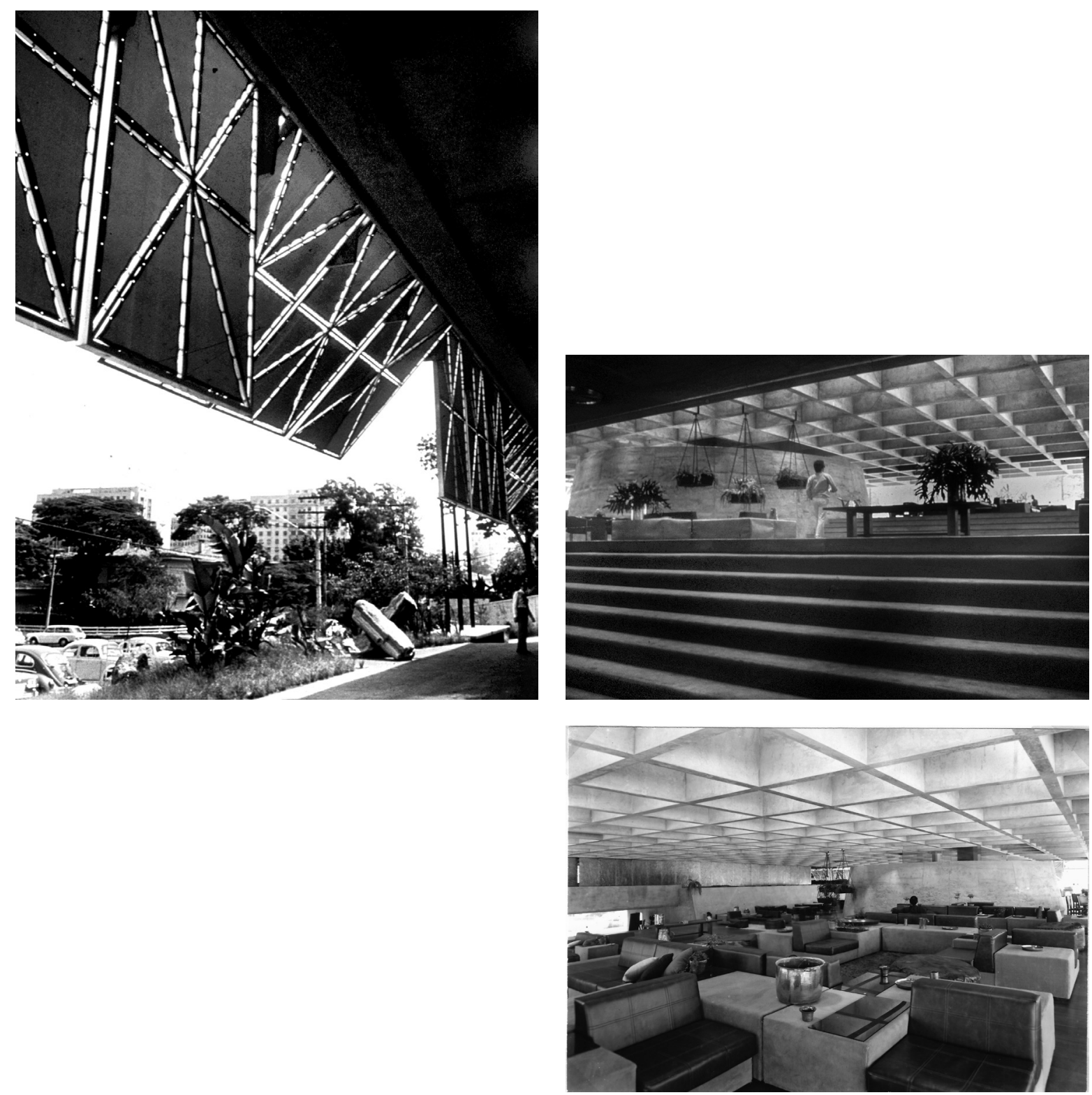

$115 \uparrow$ Área de Embarque e Desembarque do Clube Harmonia, 1971.

Fonte: Acervo do Arquivo Fábio Penteado.
$116 \uparrow$ Vista Desde a Entrada do Edifício-Sede do Clube Harmonia, 1971. Fonte: Acervo do Arquivo Fábio Penteado.

$117 \uparrow$ MASCARDI, José. Sala de Estar do Edifício-Sede do Clube Harmonia, 1971. Fonte: Acervo do Arquivo Fábio Penteado. 


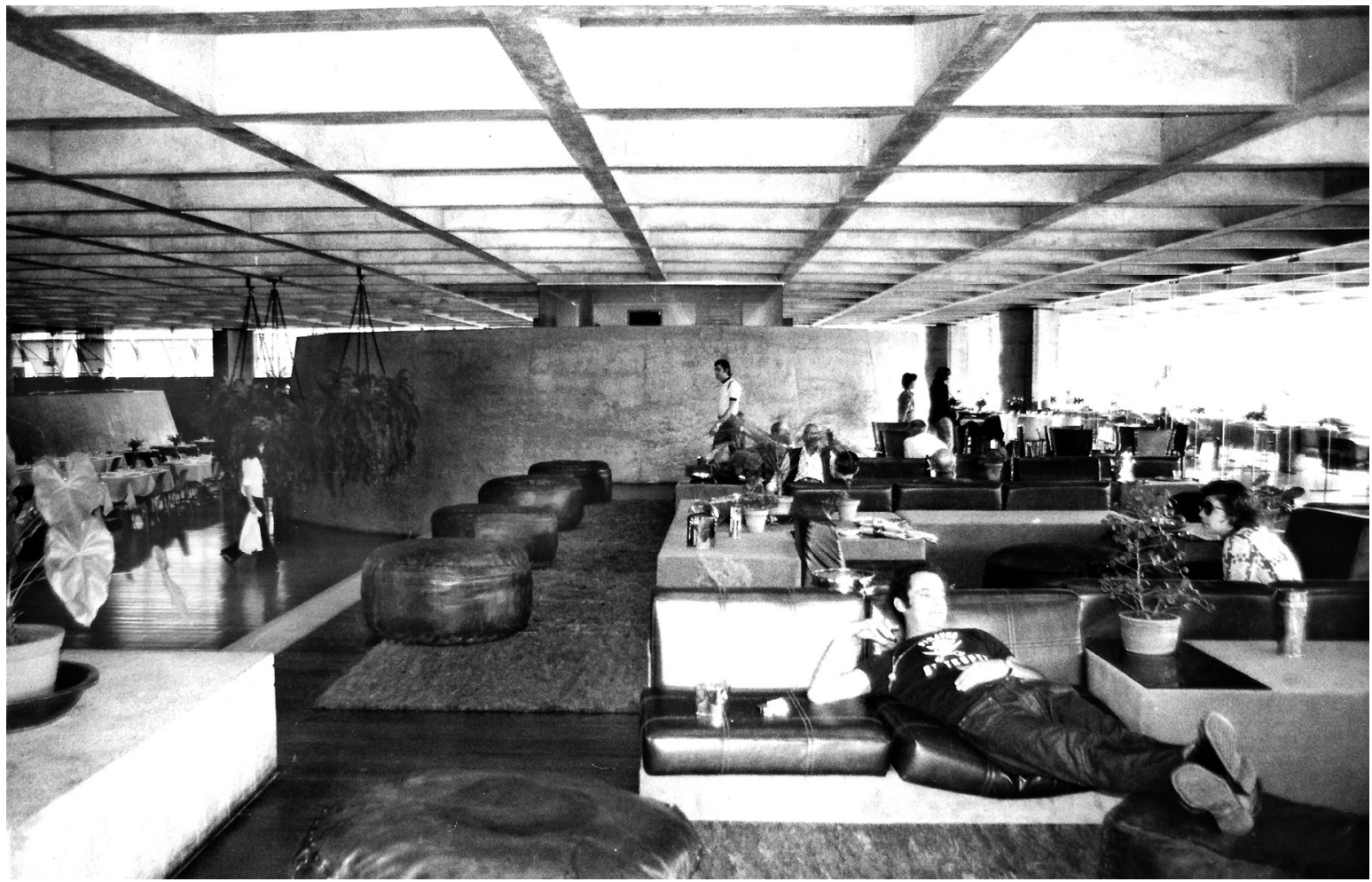

Sua proposta para o Harmonia fundamenta-se nos espaços públicos e democráticos da cidade que promovem o encontro e a convivência dos cidadãos e toma a praia e a praça como seus arquétipos:

A praia de Copacabana é um clube. Um milhão, dois milhões de pessoas vão e, mesmo sem infraestrutura, convivem num nível de cortesia. Ou qualquer pequena praça pública, onde você chega e senta num banco, e não sente constrangimento (...) Eu conheci a praia de Copacabana e cada um em Copacabana tem uma tribo, não é? Então cada um vai chegando, cumprimenta e vai pra praia. Então é uma forma de convivência. O clube tradicional no Brasil é formal. Tira até do cidadão o conforto de estar com liberdade. (...) (GIROTO, 2013, p. 450)
A relação entre o edifício e a cidade experimentada a partir dos pilotis propostos por Le Corbusier e interiorizados na obra da Escola Carioca, na qual o edifício libera o solo para a continuidade da cidade, encontra desdobramentos na obra dos arquitetos paulistas. Em análise sobre a produção dos paulistas, Segawa argumenta que:

A prática arquitetônica paulista dos anos 60 - apesar do golpe militar de 1964 - não abandonou o positivista ideário utópico de um país novo, econômica e socialmente resolvido. Mesmo distante de qualquer transformação redentora da sociedade brasileira (...), a arquitetura deveria ensaiar modelos de espaços para uma sociedade democrática, atendendo aos anseios da maioria da população. Para esses arquitetos, a cidade era concebida como um espaço democrático, espaço de convivência, de encontro. O solo urbano deveria ser de todos e assim manejado, com a minimização da propriedade privada. (SEGAWA, 2010, p. 150-151) 

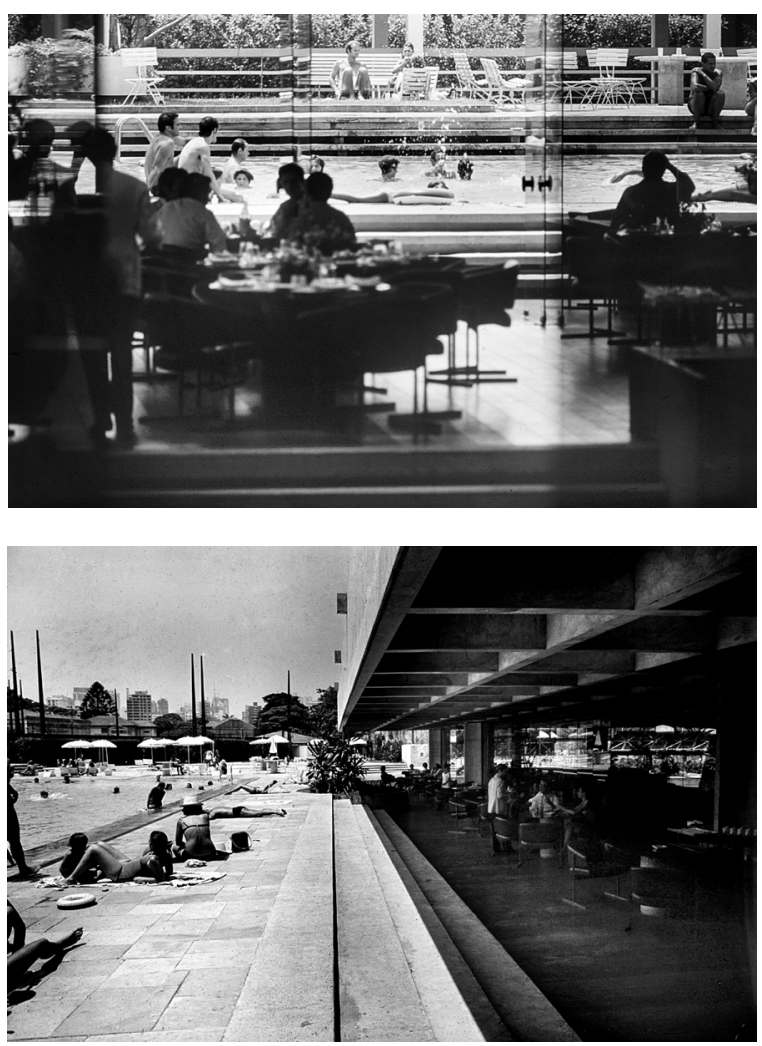
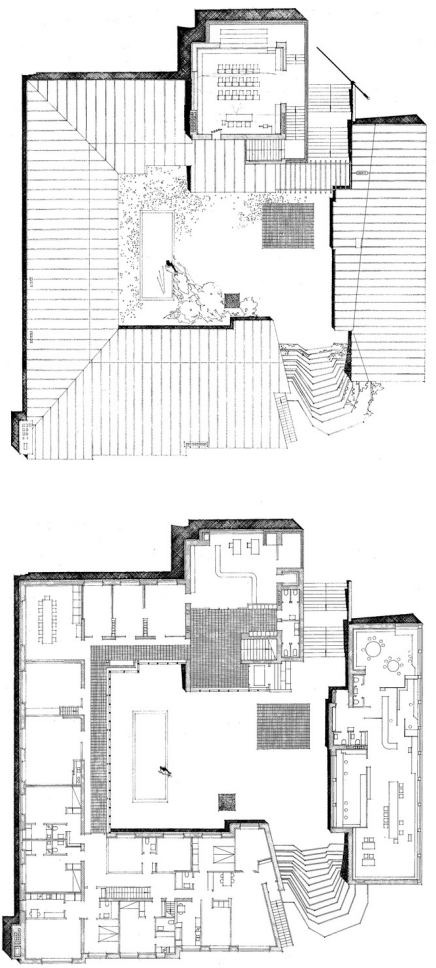

Para Wisnik (2004), os projetos desenvolvidos em São Paulo agregam ao discurso social a característica de serem predominantemente introvertidos, ao contrário da escola carioca, em decorrência da própria lógica construtiva da cidade:

Produzida em uma cidade que cresceu vertiginosamente e quase sem planejamento, sob a lógica selvagem da especulação imobiliária, essa arquitetura vai se introverter. Pois o contexto caótico e arrivista da metrópole - capital econômica e industrial do país -, tornaria insólitas as tentativas de se estabelecer relações francas e transparentes entre a construção e o tecido urbano, própria do projeto moderno, e marcante na produção carioca. (ANDREOLI e FORTY, 2004, p. 42)
$119 \uparrow$ Restaurante do Edifício-Sede do Clube Harmonia Fonte: Acervo do Arquivo Fábio Penteado.

$120 \uparrow$ Piscina do Clube Harmonia. Fonte: Acervo do Arquivo Fábio Penteado.
$121 \uparrow$ Plantas Centro Cívico de Säynätsalo, Finlândia, 1952 Fonte: Página Archdaily Brasil ${ }^{4}$ 
A ideia do vazio no edifício configurado como praça se repercute nos projetos dos fóruns paulistas, obras públicas impulsionadas pelo PAGE, citado anteriormente. Zein (2005) nota que tal arranjo espacial já havia sido explorado anteriormente na obra de Alvar Aalto, no início dos anos 1950:

Esse arranjo espacial do fórum em torno de um vazio- praça que libera parte do térreo para o usufruto da cidade, embora esteja presente também em algumas das obras de Alvar Aalto - como o Centro Cívico de Säynätsalo, Finlândia, 1952 - é igualmente comum aos projetos de fórum desse momento em São Paulo, realizados por outros autores afinados com o brutalismo paulista - como o Fórum de Promissão, de João Baptista Vilanova Artigas e Carlos Cascaldi, (1959) ou o Fórum de Araras, de Fábio Penteado, (1960) o Fórum de Avaré, de Paulo Mendes da Rocha e João de Gennaro, (1961) ou o Fórum de São José dos Campos, de Paulo Sérgio Souza e Silva (1961). (ZEIN, 2005, p. 317)

No projeto de Aalto para o Centro Cívico de Säynätsalo o edifício delimita a praça descoberta em seu centro. Com características distintas, a praça coberta interiorizada no edifício proposta pelos paulistas ocorre a partir do projeto de Penteado para o Fórum de Araras e do Ginásio de Itanhaém de Artigas, ambos de 1959, seguido pelo Ginásio de Guarulhos, de 1960, e então na obra mais representativa deste grupo, o edifício da FAU-USP de 1961, sobre a qual Penteado afirma:

O Harmonia só pôde ser feito porque eu convivia com o Artigas e vi ele fazer a FAU. Uma vez até, antes de acabar o projeto ele foi comigo na obra, e até me lembro que falei: 'Olha Artigas, eu acho que aqui vai ficar tão bonito um dia, que vão pensar que você que fez.' Então você não escapa, você convive e você é o que você vê, o que você ouve, o que você gosta de ver. (GlROTO, 2013, p.450)

Embora no caso do clube Harmonia a praça coberta se apresente como um espaço exclusivo, que distancia os seus usuários da cidade, o projeto de Penteado pode ser entendido como uma tentativa de se produzir nestas circunstâncias um espaço democrático; como a praça pertencente ao edifício, conforme o projeto de Aalto; e ainda como uma introversão da arquitetura, de acordo com Wisnik. Em uma análise poética sobre as áreas sociais do clube, Jorge Czajkowski (1948-2010) desenvolve o seguinte texto:

Este exercício de liberdade não surge dissociado de uma visão política mais ampla - encerrado ludicamente em si mesmo -, mas se baseia na aguda consciência da necessidade de elaborar uma arquitetura para a multidão, problema que a explosão demográfica coloca premência cada vez maior.

(...) É desta atitude que surge o Clube Harmonia, que sugere caminhos para a atividade de lazer. Seu interior é um momento de exterioridade aprisionado num pavilhão de luz, que não força a existência do prédio como objeto fechado, mas sim como como espaço que dignifica o relaxamento protegido frente à natureza. Os recursos utilizados para conseguir esta atmosfera são, basicamente, apenas dois. O primeiro é a desmaterialização do invólucro, que é sólido e fechado, quando visto de fora - passa a ser quase imaterial para que está dentro, filtrando magicamente a luz através de domos translúcidos e toldos reguláveis. O segundo é a articulação do solo, tratado numa sequência contínua de planos que sobem do nível da rua ao nível da piscina, as várias atividades atribuídas em patamares que lhe asseguram a escala e o isolamento apropriados sem quebra do grande espaço unitário. É uma progressão que precisa ser experimentada, esta misteriosa escadaria que parte do hall e se alarga a cada degrau, revelando novas perspectivas e alterando a compreensão do espaço. (PENTEADO, 1998, p. 175) 


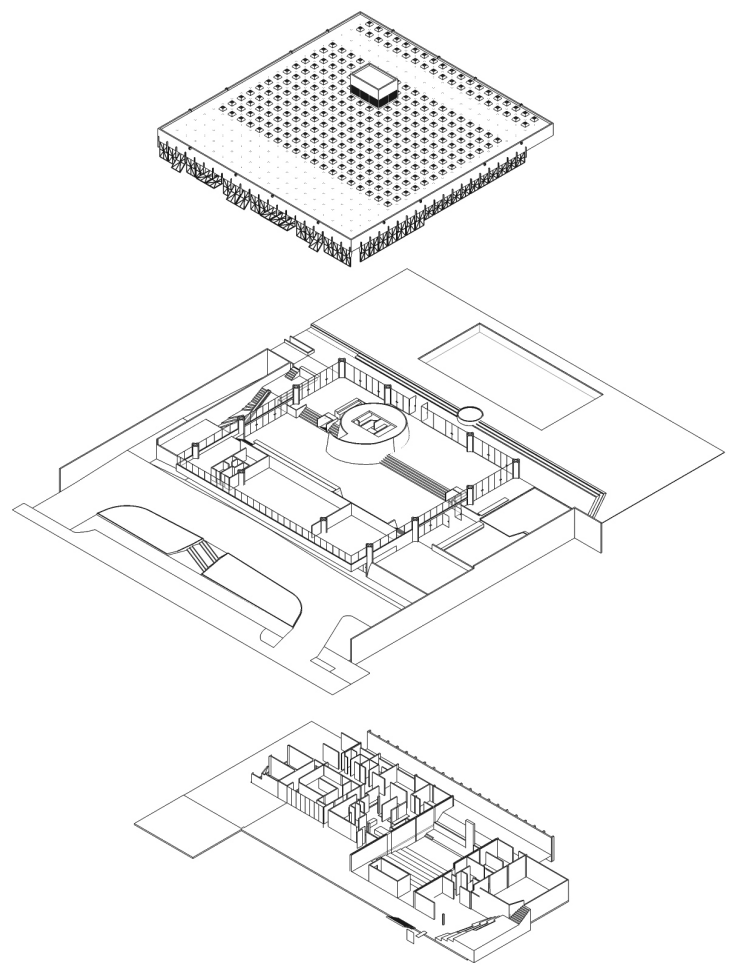

\section{COBERTURA ÚNICA}

\section{E OS PLANOS DE LAJES}

A cobertura plana e homogênea que confere unidade ao edifício, tem a sua geometria definida pelo afastamento dos recuos laterais e frontal obrigatórios para o lote, incorporando a maior área disponível para a sua implantação. Em contrapartida, os pés-direitos diminutos do patamar de acesso, com $2,50 \mathrm{~m}$, e do mezanino de jogos sobreposto, com $2,20 \mathrm{~m}$, reduzem a altura total da construção, resultando num edifício bastante horizontal.

Estas estratégias demonstram que a concepção da forma do edifício foi orientada pela mesma lógica sob a qual Artigas projetou os seus edifícios, evitando a monumentalidade das fachadas em contraponto à complexidade espacial dos ambientes internos. Pode-se sugerir, uma semelhança projetual às obras anteriormente mencionadas como a casa Olga Baeta, (1956-1957)
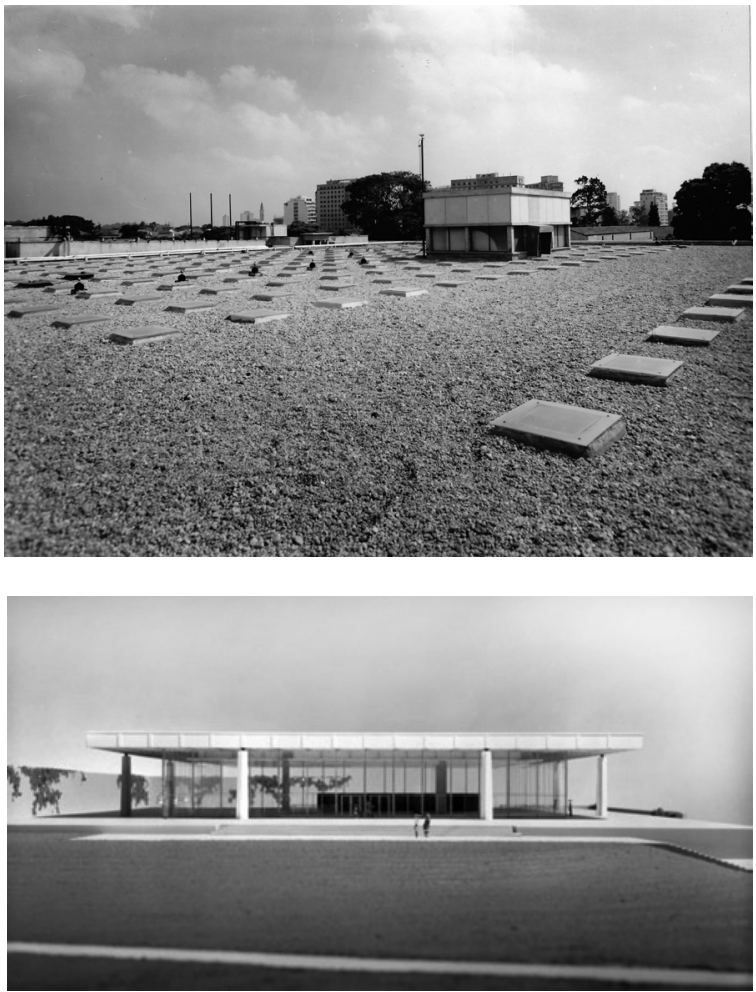

a Casa Rubens de Mendonça/Casa Triângulo, (1958) a residência Mário Taques Bittencourt, (1959) que se desdobraram posteriormente em obras de maior escala, como no Fórum de Araras, (1959) no Ginásio de Itanhaém, (1959) no Ginásio de Guarulhos, (1960) onde já se apresentam aberturas zenitais, e no edifício da FAU-USP, (1961) com a cobertura composta de uma laje estruturada por um sistema hierárquico de vigas simples, que remete à uma laje em grelha, com domos.

Embora Penteado tenha afirmado que o Harmonia tem no edifício da FAU-USP a sua referência mais direta, é necessário considerar que entre os anos de 1950 e 1962 Mies Van der Rohe produziu ao menos oito projetos que se organizam a partir de uma cobertura única apoiada em pilares perimetrais e distribuem o programa sob as suas sombras.

Dentre este conjunto, podemos destacar o edifício administrativo do Ron Bacardi em Cuba, (1957) e a Galeria Nacional de Berlim, (1962-68) para as quais Mies projetou a cobertura estruturada em grelha bidirecional
$122 \uparrow$ Modelo 3D do Edifício-Sede do Clube Harmonia, 1971. Fonte: Material Desenvolvido pelo Autor.
$123 \uparrow$ MASCARDI, José. Cobertura do Edifício-Sede do Clube Harmonia. Fonte: Acervo do Arquivo Fábio Penteado.

$124 \uparrow$ Maquete do Edifício Ron Bacardi em Cuba, Mies Van Der Rohe, 1957

Fonte: Página averyreview. ${ }^{5}$ 

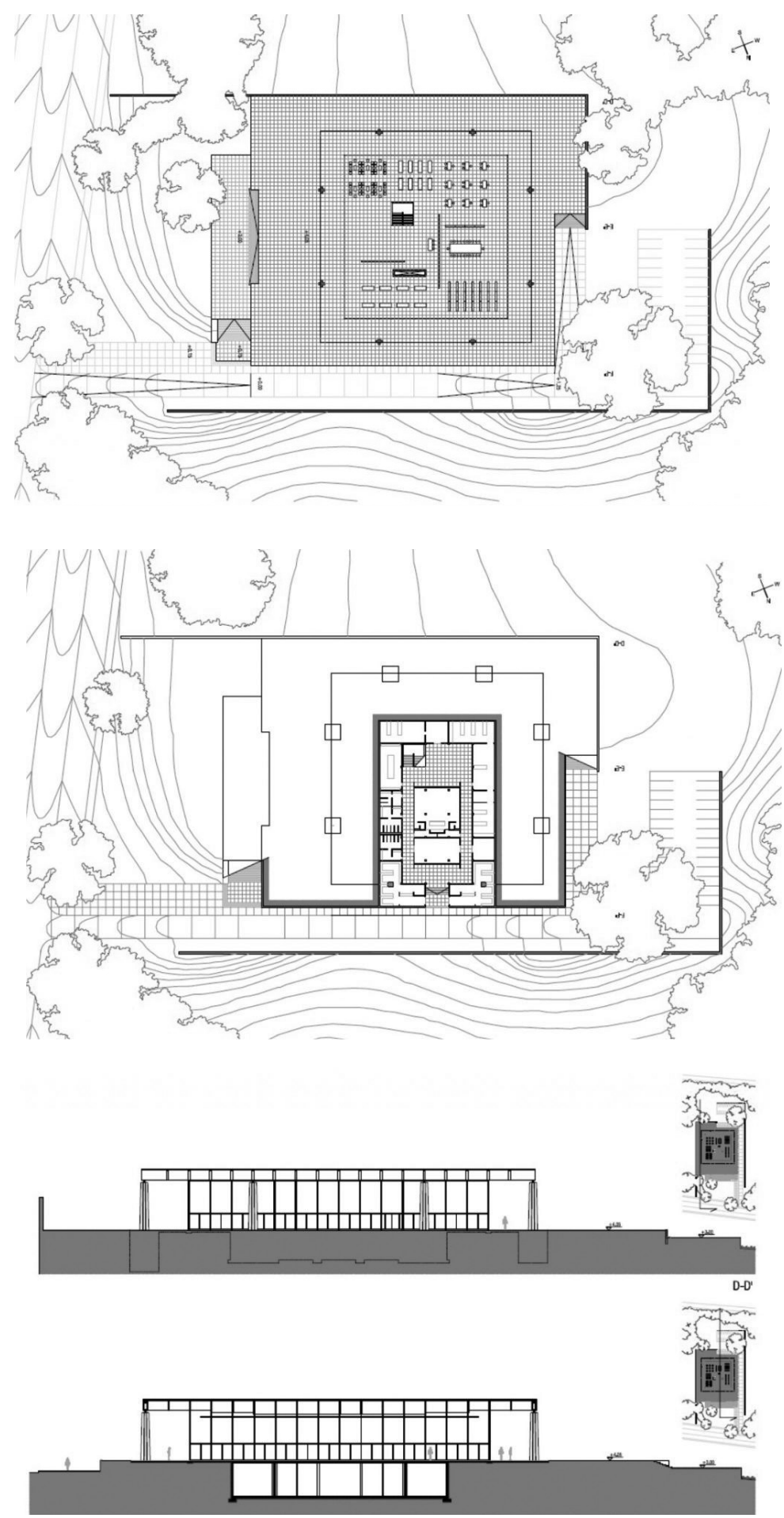

$125 \uparrow$ Planta do térreo do Edifício Ron Bacardi em Cuba, Mies Van Der Rohe, 1957

Fonte: Página wikiarquitectura. ${ }^{6}$

$126 \uparrow$ Planta do subsolo do Edifício Ron Bacardi em Cuba, Mies Van Der Rohe, 1957. Fonte: Página wikiarquitectura. ${ }^{7}$
$127 \nwarrow$ Cortes do Edifício Ron Bacardi em Cuba, Mies Van Der Rohe, 1957 Fonte: Página wikiarquitectura. ${ }^{8}$ 


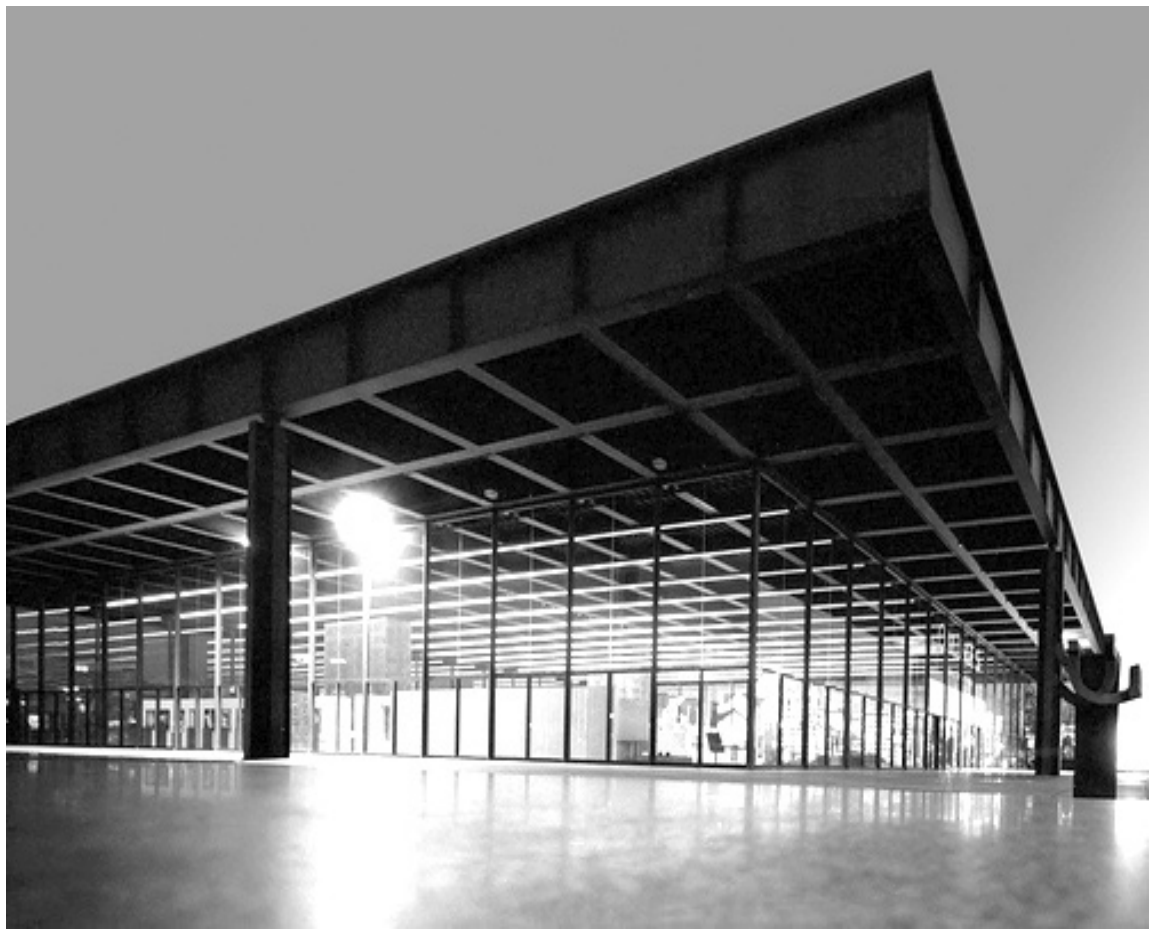

homogênea apoiada em pilares cruciformes e implantou o seu programa compartimentado no subsolo, enfatizando a continuidade espacial em seu interior e revelando à paisagem uma caixa diáfana, ligeiramente elevada em relação ao solo.

Podemos ainda encontrar entre o edifício-sede e as obras de Mies a associação entre a simplicidade formal e alta capacidade técnica, além do princípio que define a arquitetura do edifício a partir de sua estrutura.

Projetado em concreto armado, o edifício Ron Bacardi é uma exceção deste conjunto das obras de Mies. Em comparação à obra de Artigas, Cotrim (2009) argumenta que:

Nos projetos de Artigas depois de 1956 prevaleceu a utilização do concreto armado in loco; nos de Mies, com uma evidente anterioridade, prevaleceu a partir da década de 1930 a utilização de estruturas metálicas industrializadas. Por trás desta evidente e importante diferença esconde-se uma atitude que em essência os aproxima: a eleição de materiais condizentes com a realidade técnica local, tanto no que diz respeito a questões orçamentárias como tecnológicas e construtivas. Se considerarmos a prevalência da obra de Mies - depois de 1937 - nos Estados Unidos, a escolha dos materiais, nos dois casos, se insere numa possível tradição moderna local. (COTRIM, 2009)

A arquitetura da vanguarda moderna paulista, conforme Zein analisa em sua pesquisa de doutorado, não é uma tradução literal destes projetos de Mies. No Harmonia, assim como no edifício da FAU-USP, as lajes dos pisos estão intercaladas em meios-níveis, independentes da cobertura homogênea, tornando os ambientes interiores mais complexos. Nos projetos públicos citados anteriormente, existe a intenção de continuidade do solo urbano no chão do edifício e, embora existam barreiras físicas no acesso do Harmonia, Penteado faz referência à praça pública em seu projeto. Em Mies, a planta principal é térrea e os edifícios estão apartados do espaço público como um monumento. 

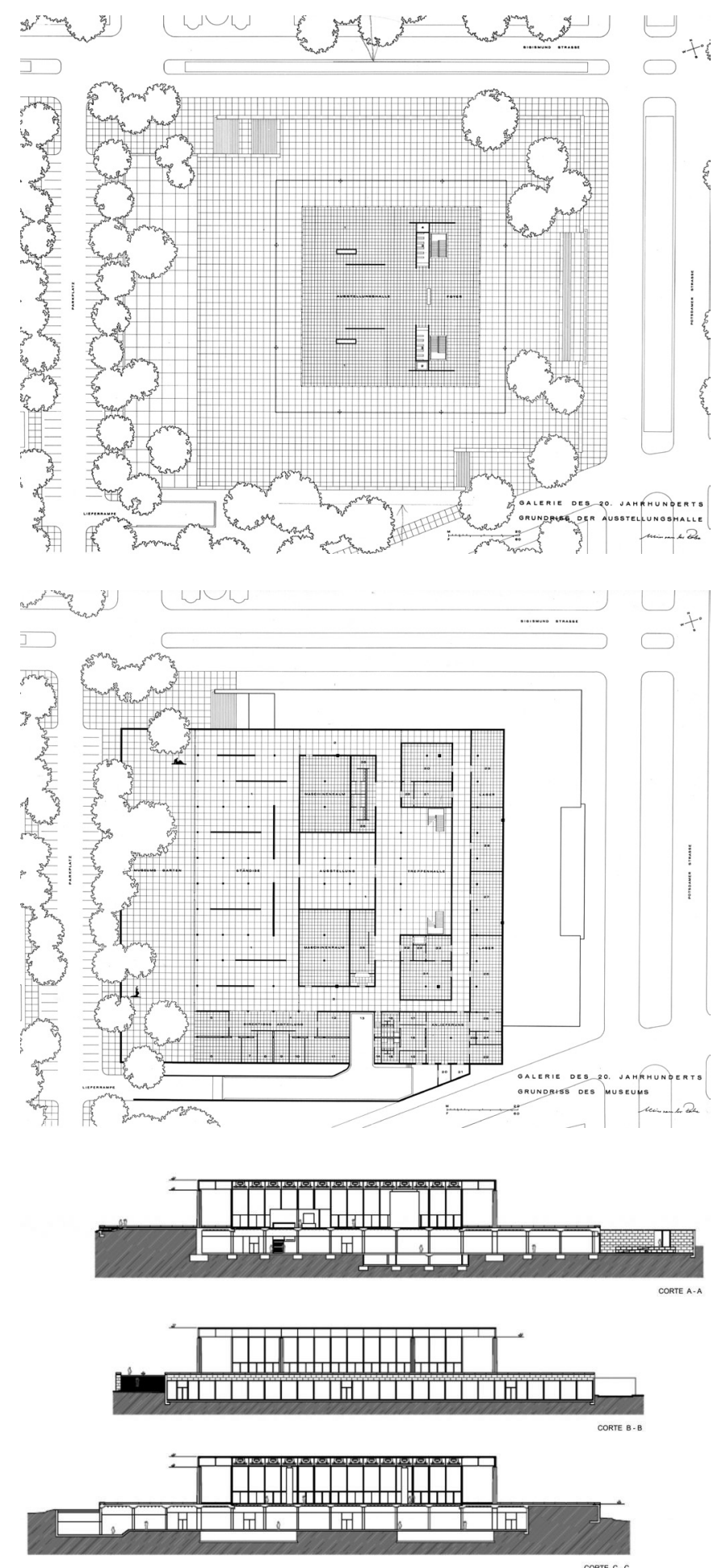

$129 \uparrow$ Planta do Térreo da Galeria Nacional de Berlim, Mies Van Der Rohe

Fonte: Página atlasofspaces.10

$130 \uparrow$ Planta do Subsolo da Galeria Nacional de Berlim, Mies Van Der Rohe.Fonte: Página atlasofspaces. ${ }^{11}$
$131 \nwarrow$ Cortes da Galeria Nacional de Berlim, Mies Van Der Rohe Fonte: Página wikiarquitectura. ${ }^{12}$ 


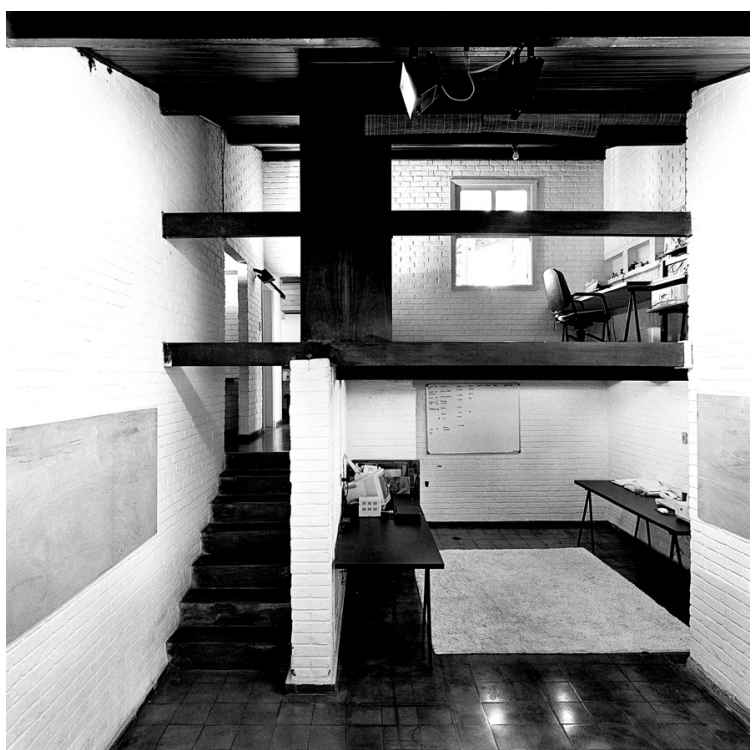

A implantação do programa por meios níveis, sem perder a continuidade espacial, pode ser observado nas obras de Artigas a partir da Casa do Arquiteto, a $\mathrm{Ca}$ sinha, de 1942. Esta estratégia projetual ocorre também nas obras de maior escala como nos Ginásios de Itanhaém, de 1959, Guarulhos, 1960, na FAU-USP, de 1961 e Utinga, 1962.

O edifício-sede apresenta os seus desníveis e mezanino com especial similaridade ao Ginásio de Guarulhos (1960), inclusive no que diz respeito ao desenho dos bancos de base angulada utilizados como guarda-corpo e dos arrimos inclinados. Com a variação ascendente de meios-níveis entre o acesso e o platô mais alto com a piscina no Clube Harmonia e as salas de aula no caso do Ginásio, ambos sob uma cobertura plana. Também possuem em comum o acesso com pé-direito reduzido sob o mezanino e ampliado nos ambientes sucessivos.
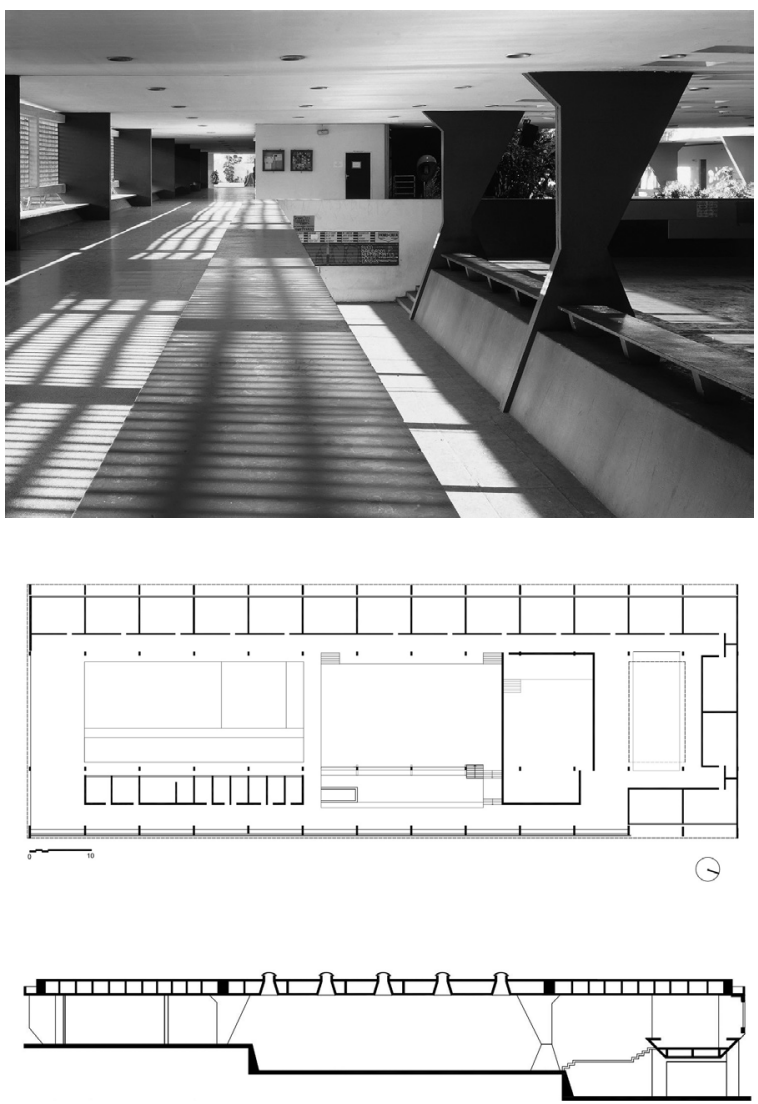

$132 \uparrow$ Casinha, Vilanova Artigas Fonte: Página Vilanova Artigas. ${ }^{13}$
$133 \uparrow$ Ginásio de Guarulhos. Fonte: Página Archdaily Brasil. ${ }^{14}$

$134 \uparrow$ Planta do Ginásio de Guarulhos

Fonte: Página Archdaily Brasil. ${ }^{15}$

$135 \uparrow$ Corte Longitudinal do Ginásio de Guarulhos Fonte: Página Archdaily Brasil. ${ }^{16}$ 


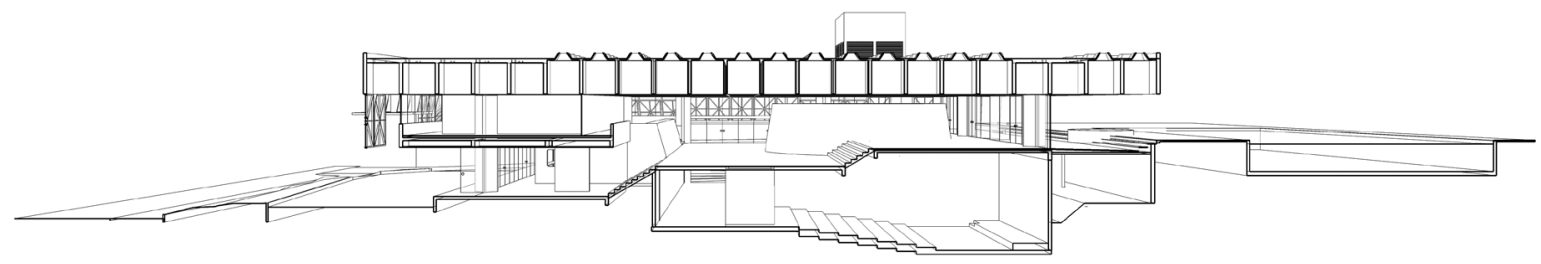

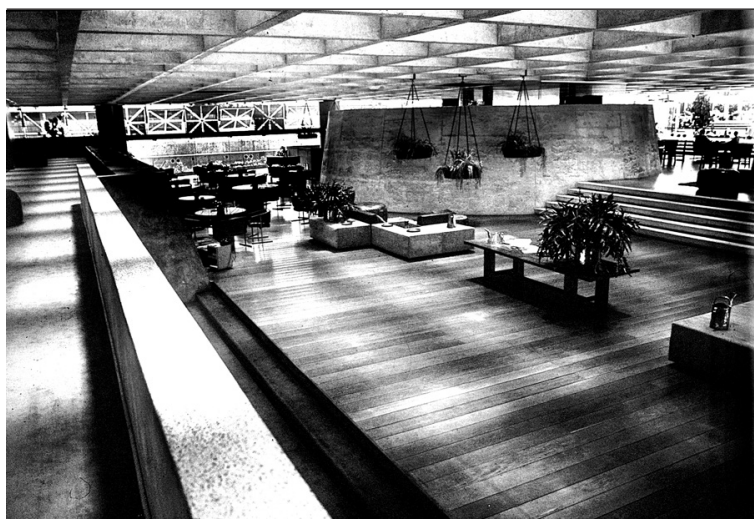

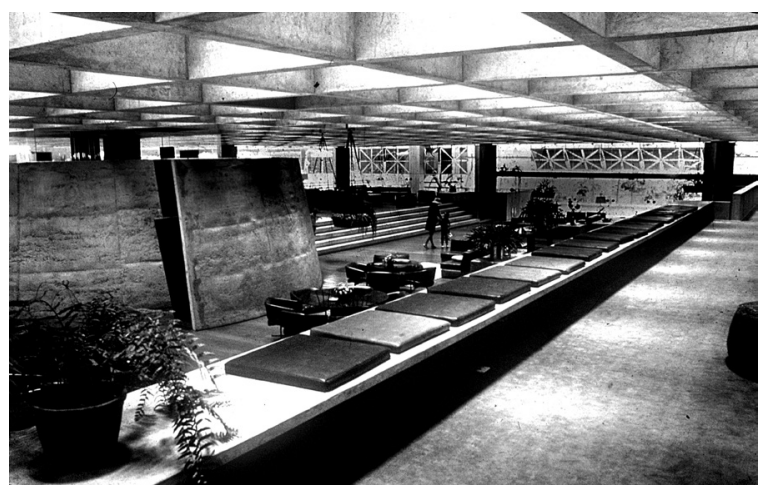

\section{REDESENHO DA TOPOGRAFIA}

A partir da leitura dos cortes longitudinais do edifício-sede, é possível compreender como Penteado adapta o edifício à topografia pré-existente. Esta operação, recorrente na obra da vanguarda moderna paulista, deve-se, em parte, ao relevo irregular da cidade de São Paulo, mas também ao desejo de tornar o térreo do edifício continuidade do espaço público, em contraposição à arquitetura do monumento encerrado em si mesmo. Zein (2005) afirma que esta não é uma operação que represente por si só a obra dos paulistas:

Embora a arquitetura moderna manifeste sempre, caracteristicamente, o desejo de liberação do solo (indicado claramente nos cinco pontos de Le Corbusier), e o tratamento do chão enquanto composição espacial seja, sem dúvida, um dos pontos fortes da Arquitetura Paulista Brutalista, que não pousa delicadamente no lugar, mas, talvez por força da topografia ondulada da geografia local, vê-se sempre solicitada a projetar e amoldar o chão; e embora essa não seja característica exclusiva dos paulistas - podendo já ser encontrada na definição urbanística de Brasília, por exemplo - não se pode dizer levianamente que essa seria uma característica propriamente típica da arquitetura da escola carioca - ou, ao menos, não é o traço que poderia ser escolhido para melhor representá-la. (ZEIN, 2005, p. 343)

O texto de Zein pode ser complementado pela leitura Annette Spiro sobre a obra de Paulo Mendes da Rocha: Bauten und Projekte, de 2002:
$136 \uparrow$ Modelo 3D do Edifício-Sede do Clube Harmonia Fonte: Material Desenvolvido pelo Autor.
$137 \nwarrow$ Ambientes de Estar do Edifício-Sede do Clube Harmonia Fonte: Acervo do Arquivo Fábio Penteado.

$138 \nwarrow$ Mezanino do Edifício-Sede do Clube Harmonia Fonte: Acervo do Arquivo Fábio Penteado. 

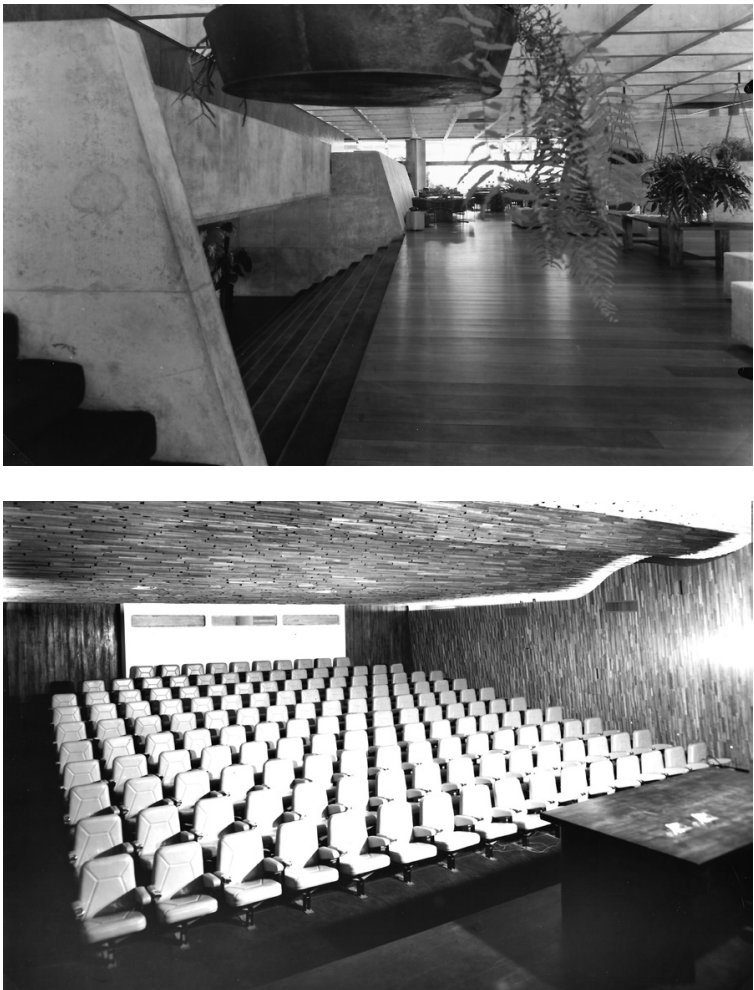

One can imagine Le Corbusier's Villa Savoie removed from its surroundings, and with little power of imagination one can then imagine the natural surroundings in their untouched state once again. In this intellectual experiment both the terrain and the building remain relatively unharmed.

This is not the case of Paulo Mendes da Rocha. Should one try to remove his buildings from their terrain not only scars remain behind, but the buildings themselves became fragments. (SPIRO, 2002, p. 19).

Em Penteado, é nítida esta operação, principalmente a partir do projeto não construído para o Teatro Municipal de Piracicaba, do ano de 1960, que torna não o térreo, mas a cobertura do edifício uma praça sempre aberta à comunidade.

Contra aquele teatro que só abre as portas na hora do espetáculo, um teatro que seja usado e tenha rentabilidade 24 horas por dia: se você usa dinheiro público, deve garantir uma rentabilidade cultural, como se fosse o melhor negócio. (PENTEADO, 1998, p. 92)
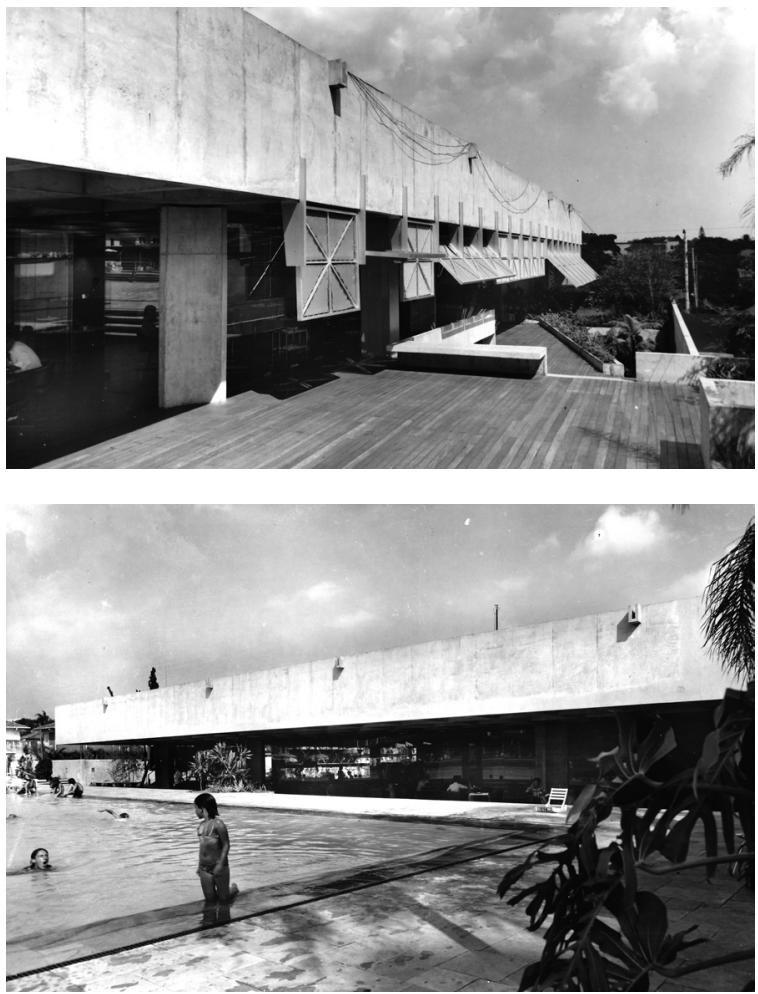

Para o projeto do edifício-sede, Penteado organiza o programa social a partir do térreo em percurso ascendente intercalado em meios-níveis, desde a entrada até a piscina, com grande ênfase para a continuidade espacial. O mezanino, sobre a secretaria, possui fechamentos removíveis, para resguardar este ambiente nos momentos em que é utilizado para a prática de bridge e possibilitar a sua integração com as áreas de estar e restaurante quando houver reuniões de grande público. Os demais programas utilizados pelos associados que necessitam de compartimentação, e poderiam inviabilizar a continuidade visual, como o auditório e banheiros, são implantados no subsolo.

Os ambientes dedicados aos serviços de atendimento aos salões tais quais vestiários, cozinha de primeiro preparo, despensa, adega e câmara-fria estão implantados abaixo do nível do solo. Desta maneira, além de evitar compartimentações nas áreas sociais, todo o fluxo de funcionários, mercadorias e lixo ocorrem sem interferir na dinâmica da praça de uso coletivo.
$139 \uparrow$ MASCARDI, José. Ambientes de Estar do Edifício-Sede do Clube Harmonia, 1971 Fonte: Acervo do Arquivo Fábio Penteado.

$140 \uparrow$ MASCARDI, José. Auditório do EdifícioSede do Clube Harmonia, 1971 Fonte: Acervo do Arquivo Fábio Penteado.
$141 \uparrow$ MASCARDI, José. Fachada Lateral do EdifícioSede do Clube Harmonia, 1971

Fonte: Acervo do Arquivo Fábio Penteado.

$142 \uparrow$ MASCARDI, José. Piscina do Clube Harmonia, 1971 Fonte: Acervo do Arquivo Fábio Penteado. 


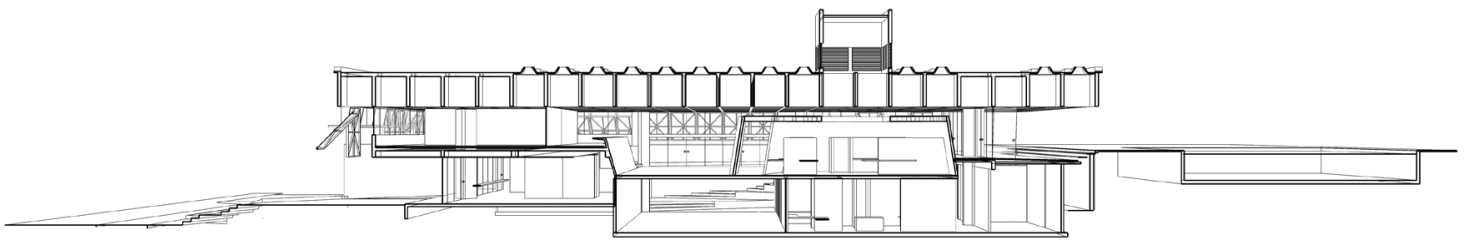

\section{FORMA DE EXCEÇÃO}

O volume em forma de tronco de cone, no qual está localizada a copa, é a peça fundamental na articulação entre o programa de serviços implementados no subsolo e as áreas de restaurante e de bar no térreo. Uma escada e um monta-cargas, internos à copa, conecta o fluxo de funcionários e alimentos entre os dois níveis.

A saída da copa para o salão remete às pernas dos palcos italianos. Os funcionários se apresentam aos associados do clube somente após vestirem os seus uniformes no subsolo para realizarem o atendimento no salão.

Sem encostar no teto, este volume cônico em concreto aparente não se revela como um fundo mas como uma peça que permite a continuidade visual do ambiente social. Visto em corte e em planta, é uma forma de exceção no projeto, concebido a partir da disposição ortogonal em malha que organiza e distribui os ambientes do clube. Penteado implanta esta forma de exceção, uma espiral em planta, de maneira a organizar os ambientes a sua volta, desimpedindo a passagem e as perspectivas visuais, entre a portaria e a piscina, e resguardando a área de bar e restaurante.

A estratégia projetual de organizar os ambientes em planta, praticamente sem divisões, a partir de um volume solto, foi recorrente na produção dos maiores expoentes da arquitetura moderna: Frank Lloyd Wright pode ser considerado o precursor na utilização desta estratégia com os projetos para as prairie houses, entre 1900 e 1917; Le Corbusier se utilizou de volumes com formas orgânicas, contendo frequentemente os banheiros das casas, desde a Villa à Vaucresson, em 1922; e Mies os implantou sob a sua matriz ortogonal, para abrigar geralmente os banheiros e cozinhas, desde o projeto para a Farnsworth House, em 1951.
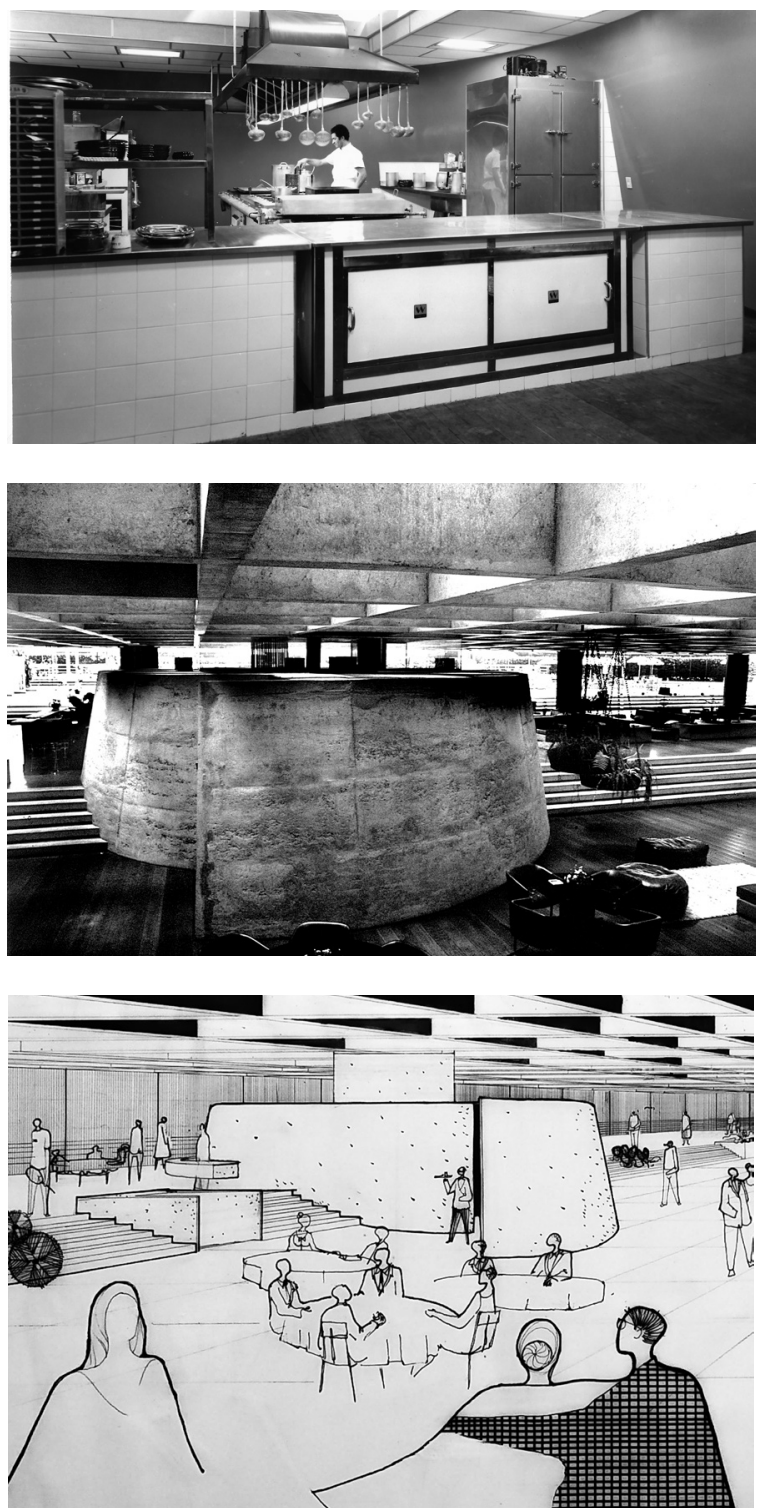

$145 \uparrow$ MASCARDI, José. Copa do Edifício-Sede do Clube Harmonia, 1971. Fonte: Acervo do Arquivo Fábio Penteado.

$146 \uparrow$ Detalhe da Perspectiva - Estudo para o Concurso de Anteprojetos da Sociedade Harmonia de Tênis, São Paulo, 1964. Fonte: Acervo do Arquivo Fábio Penteado. 

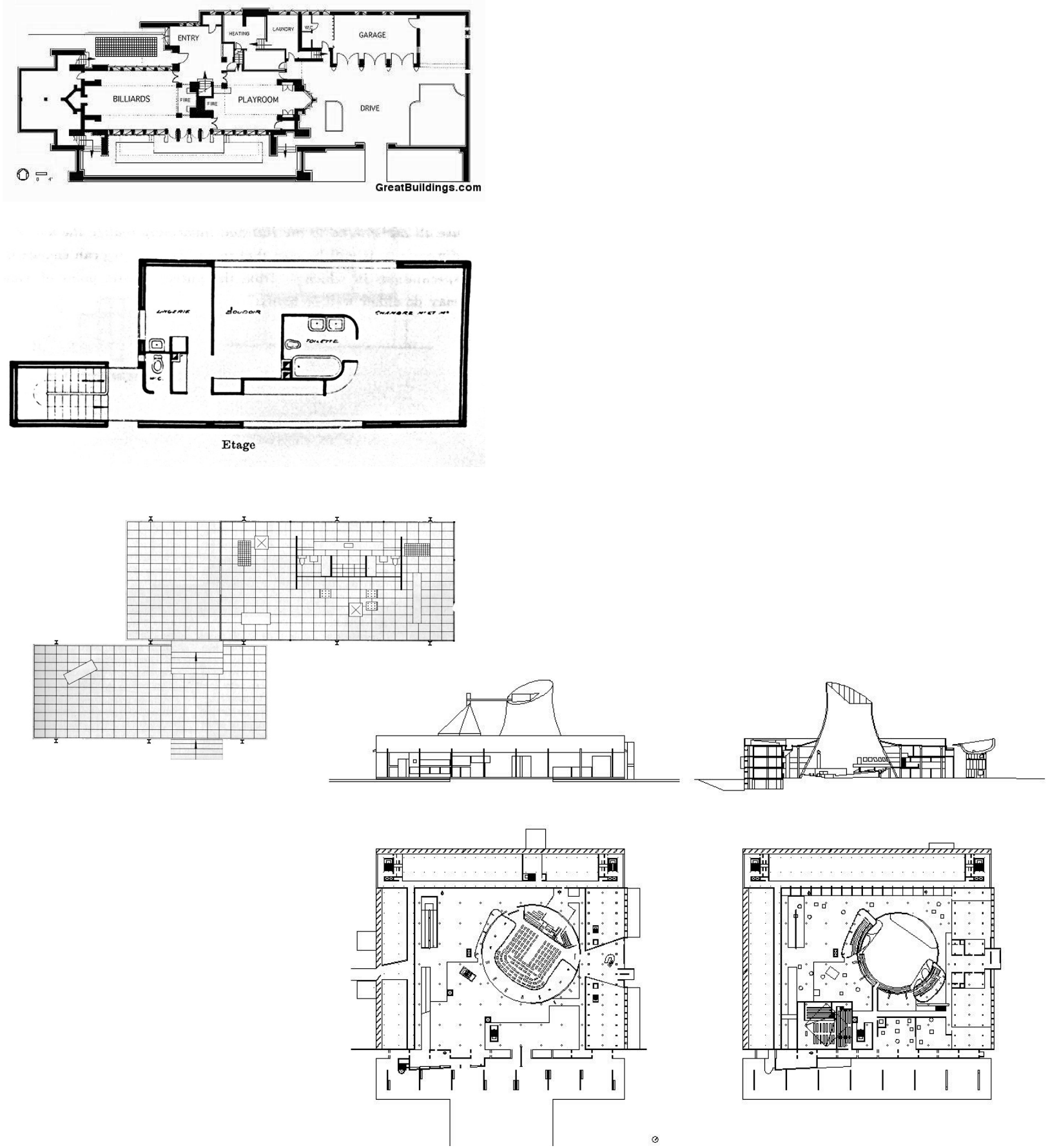

$147 \uparrow$ Planta do Térreo da Robie House, Frank Lloyd Wright, 1908-1910. Fonte: Página Archdaily Brasil. ${ }^{17}$

$148 \uparrow$ Planta do Térreo da Vila Vaucresson, Le Corbusier, em 1922 Fonte: BOESIGER, 2006, p. 51.
$149 \nwarrow$ Planta Farnsworth House, Mies Van Der Rohe, 1951 Fonte: Página Commo. ${ }^{18}$

$150 \uparrow$ Plantas e Cortes do Palácio da Assembleia em Chandigarh de Le Corbusier , 1951-1963.

Fonte: Página slideshare. ${ }^{19}$ 


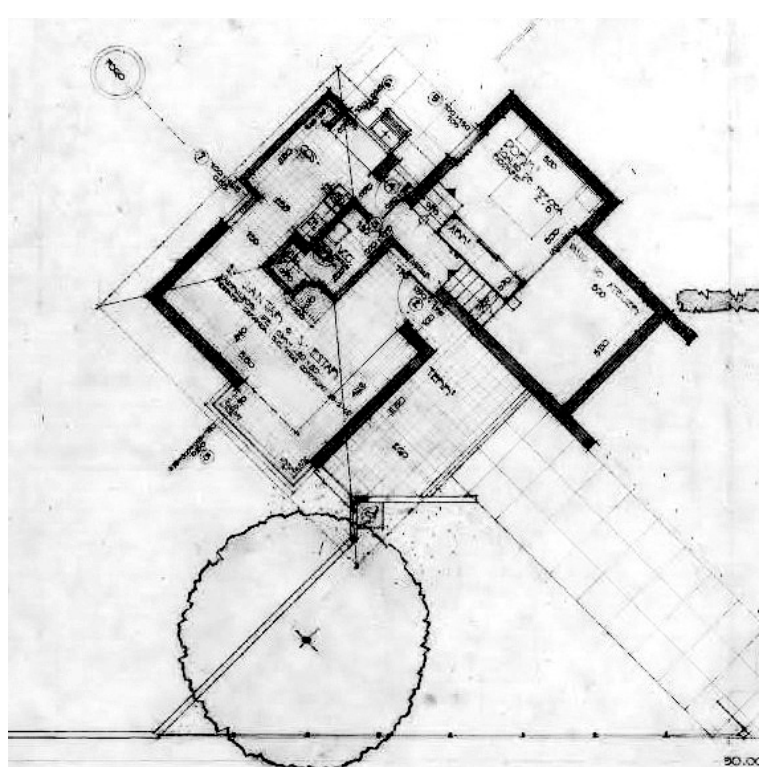

Experimentada nas casas, esta estratégia foi aplicadas posteriormente em obras de maior escala. Não se pode deixar de considerar o projeto para o Palácio da Assembleia em Chandigarh, de Le Corbusier, 1951-1963, inaugurado um ano antes do concurso para o edifício-sede do clube Harmonia. O edifício possui um volume tronco de cone de grandes proporções, que adquire protagonismo de programa e forma em sua arquitetura.

No Brasil, Vilanova Artigas organiza os ambientes da Casinha, de 1942, a partir do volume da lareira e banheiro ao centro, em esquema semelhante à Wright. Na Segunda Casa do Arquiteto, o núcleo hidráulico de banheiros define as áreas de sala e cozinha. Para citar uma obra de maior escala, no Ginásio de Guarulhos (1960) Artigas implanta os programas em volumes independentes sob a cobertura única. $O$ auditório é a peça fundamental na configuração do pátio central e do jardim.
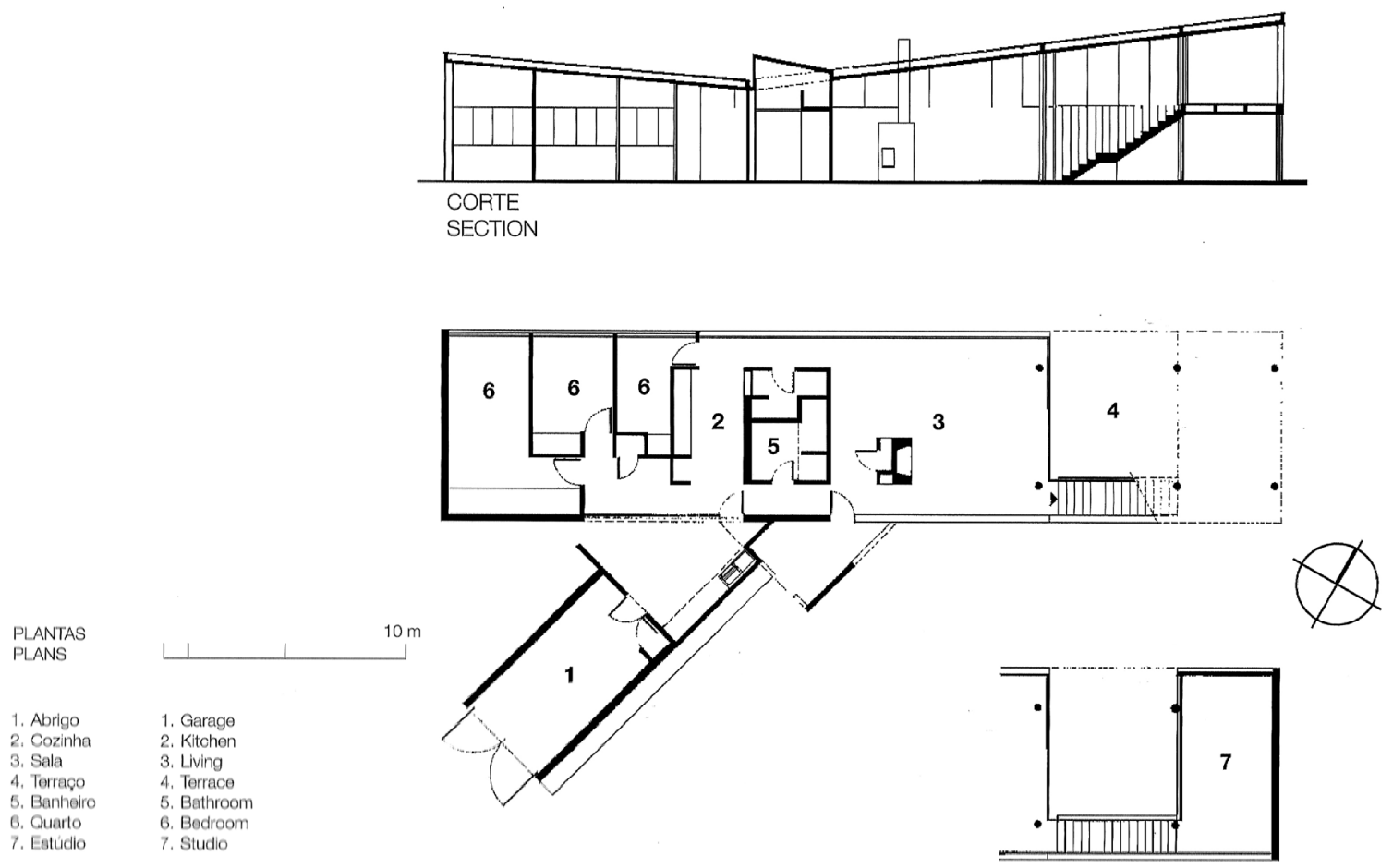

$151 \uparrow$ Planta do Térreo Casinha, Vilanova Artigas, 1942 Fonte: Kamita, 2000, p. 49.

$152 \uparrow$ Planta e Corte da Segunda Casa do Arquiteto, Vilanova Artigas, 1949 Fonte: Kamita, 2000, p. 61. 

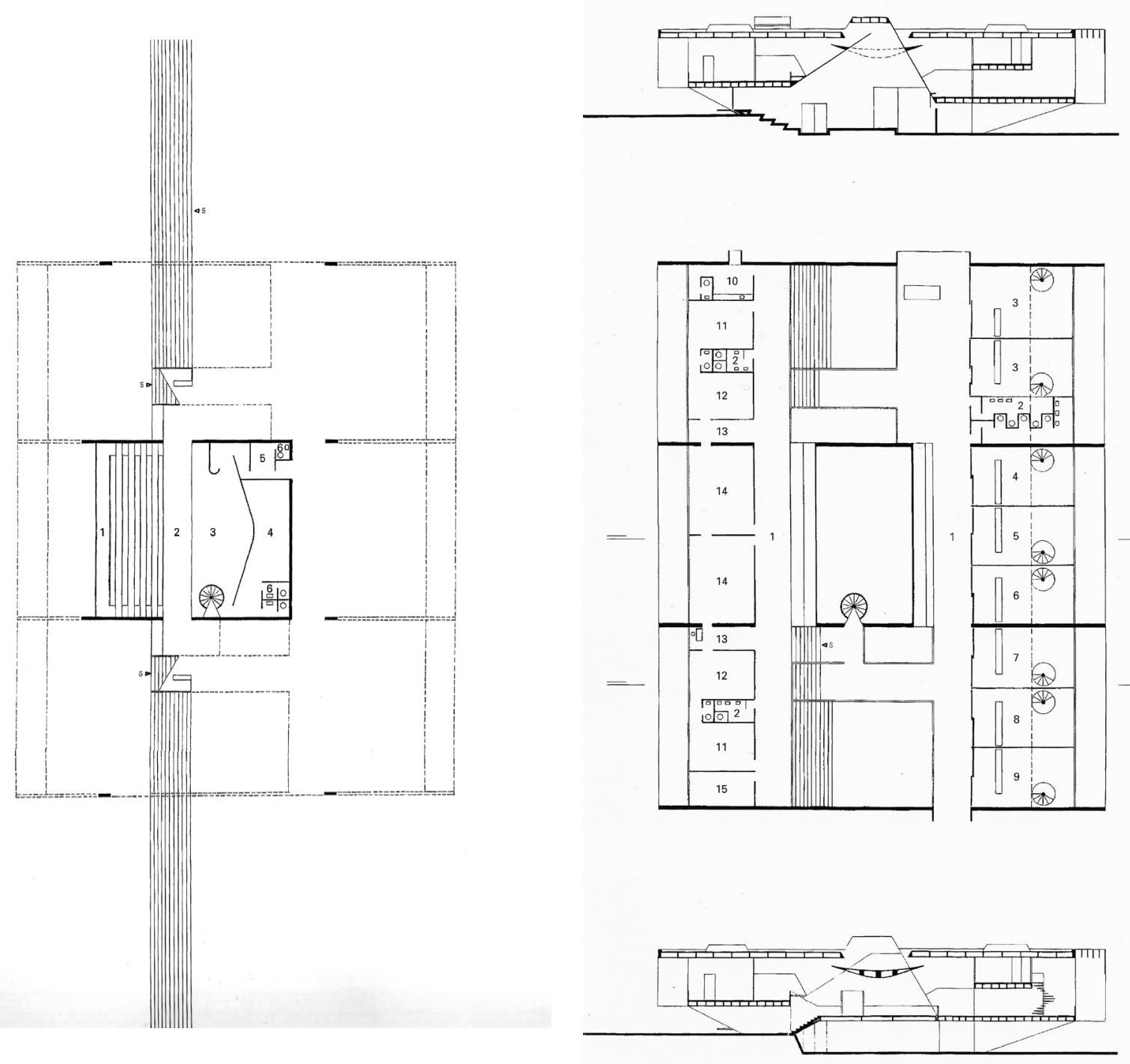
da Rocha, 1961. Fonte: Artigas, 2000, p. 140.
$154 \uparrow$ Planta do Segundo Pavimento e Cortes do Fórum de Avaré, Paulo Mendes da Rocha, 1961.

Fonte: Artigas, 2000, p. 141. 

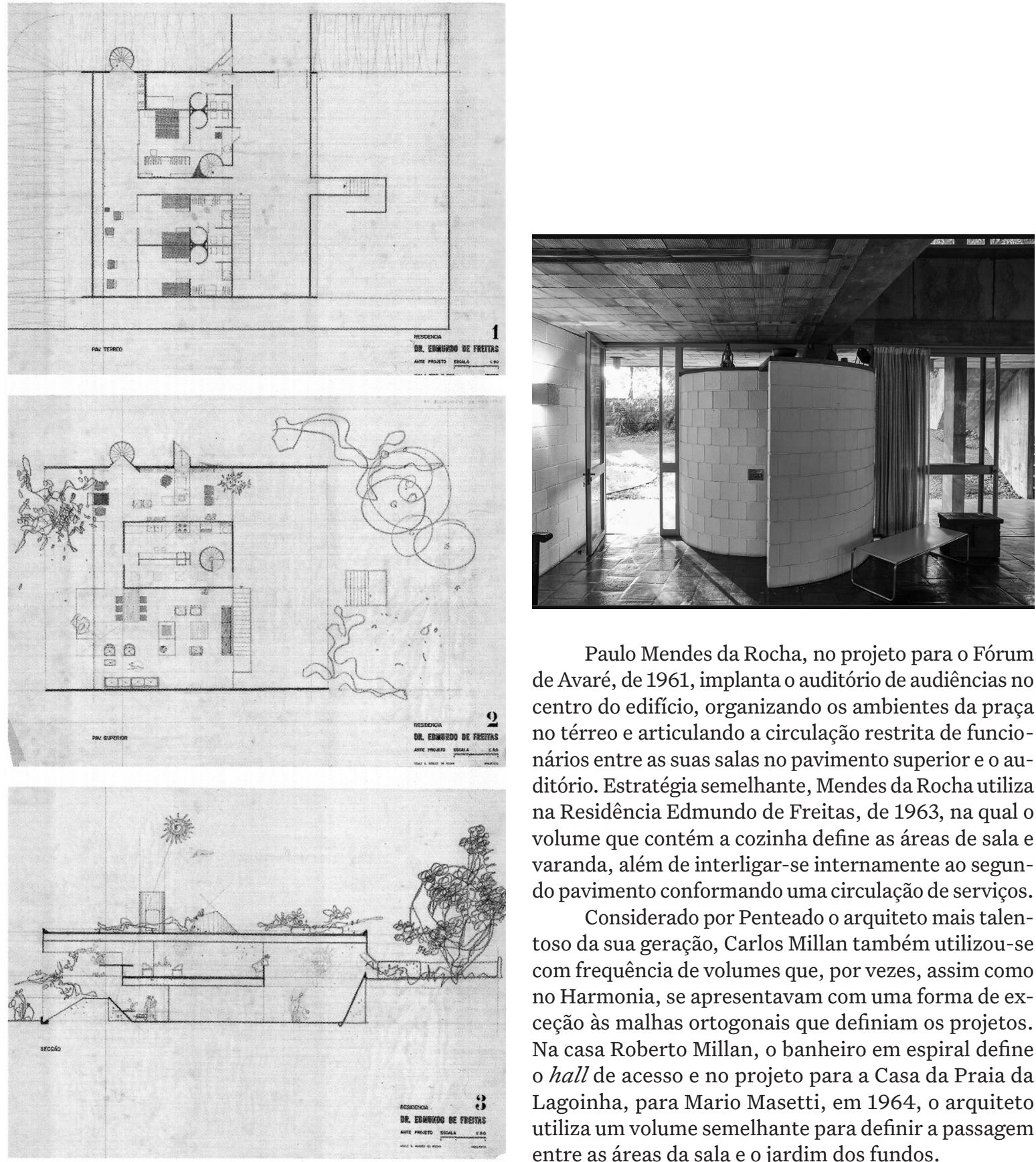

Paulo Mendes da Rocha, no projeto para o Fórum de Avaré, de 1961, implanta o auditório de audiências no centro do edifício, organizando os ambientes da praça no térreo e articulando a circulação restrita de funcionários entre as suas salas no pavimento superior e o auditório. Estratégia semelhante, Mendes da Rocha utiliza na Residência Edmundo de Freitas, de 1963, na qual o volume que contém a cozinha define as áreas de sala e varanda, além de interligar-se internamente ao segundo pavimento conformando uma circulação de serviços.

Considerado por Penteado o arquiteto mais talentoso da sua geração, Carlos Millan também utilizou-se com frequência de volumes que, por vezes, assim como no Harmonia, se apresentavam com uma forma de exceção às malhas ortogonais que definiam os projetos. Na casa Roberto Millan, o banheiro em espiral define o hall de acesso e no projeto para a Casa da Praia da Lagoinha, para Mario Masetti, em 1964, o arquiteto utiliza um volume semelhante para definir a passagem entre as áreas da sala e o jardim dos fundos.

$155 \uparrow$ Plantas da Residência Edmundo de Freitas, Paulo Mendes da Rocha, 1963.

Fonte: PISANI, 2013. p. 106.
$156 \uparrow$ Stankuns, 2013. Casa Roberto Millan, Carlos Millan Fonte: Página de Fernando Stankuns. ${ }^{20}$ 


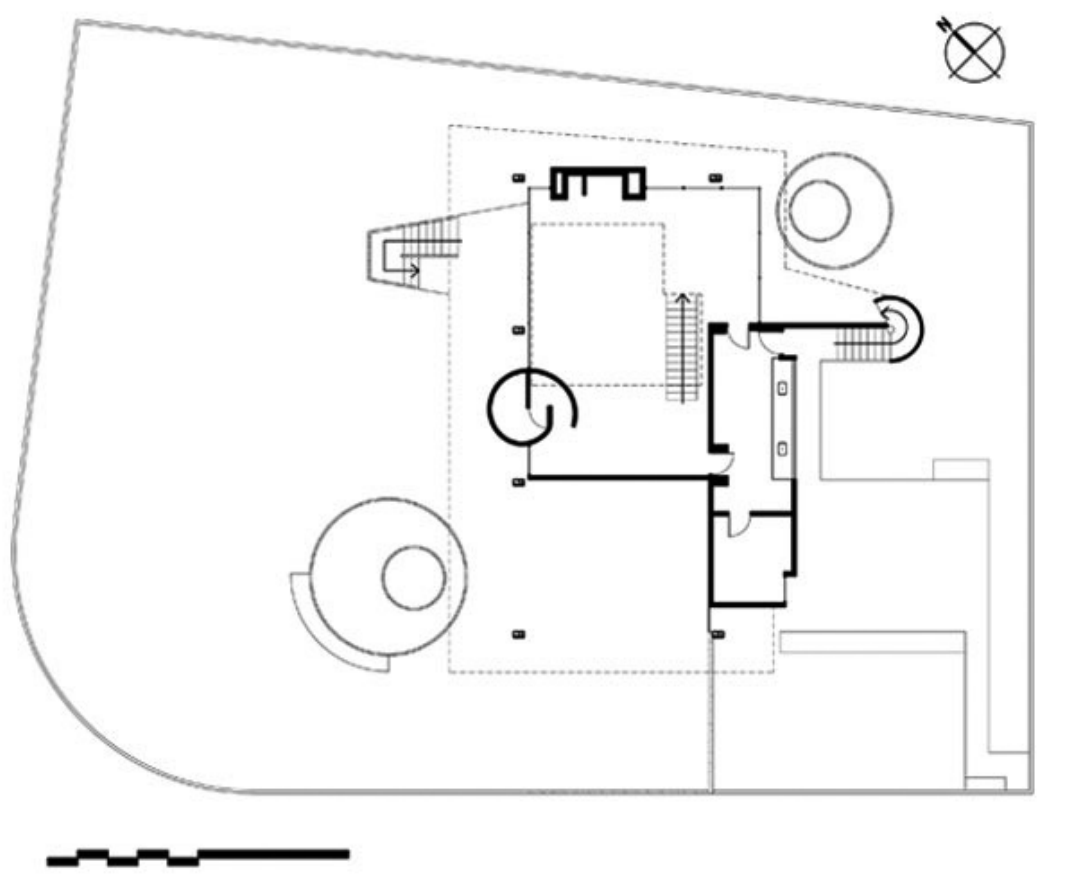

A tentativa de encontrar pontos de convergência entre as obras e arquitetos aqui mencionados não buscou estabelecer um jogo de espelhos entre elas, mas explorar, a partir dos seus antecedentes e a produção contemporânea daquele momento, o contexto no qual o edifício-sede foi produzido, apontando similaridades e descolamentos. Dentre o conjunto de obras da vanguarda moderna paulista, o edifício-sede da Sociedade Harmonia de Tênis é um dos poucos exemplares a contemplar uma execução primorosa e manter-se íntegro até os dias atuais, na relação entre a sua estrutura e arquitetura, permitindo a verificação in loco das estratégias projetuais dos arquitetos e a obra concebida.

Podemos verificar que as estratégias em conceber o edifício vinculado ao discurso da praça pública, a partir de uma cobertura única e da transformação da topografia, fazem parte de um ideal moderno tão arraigado que ainda reverberam na arquitetura contemporânea paulista.

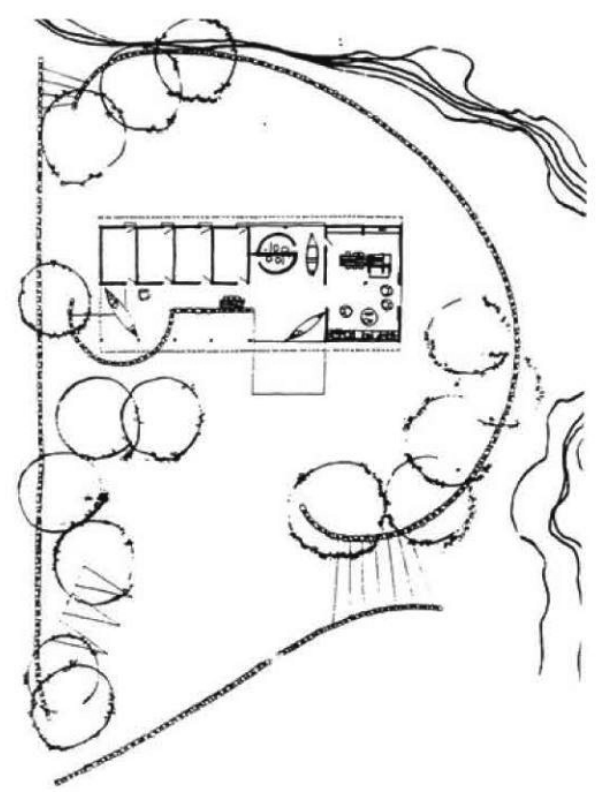

$157 \uparrow$ Planta do Térreo da Casa Roberto Millan, Carlos Millan. Fonte: Pagina Arquitetura Brutalista. ${ }^{21}$
$158 \uparrow$ Implantação da Casa da praia da Lagoinha, para Mario Masetti, Carlos Millan. Fonte: BAROSSI, 2005. p.142. 
Disponível em: https://en.wikiarquitectura.com/ building/bacardi-office-building-in-santiago-decuba/\#bacardi-cortes3. Acesso em: 01 de Dez. 2019.

9 Disponível em: https://www.atlasofplaces.com/architecture/ neue-nationalgalerie/\#figure-12. Acesso em: 01 de Dez. 2019.

10 Disponível em: https://www.atlasofplaces.com/architecture/ neue-nationalgalerie/\#figure-4. Acesso em: 01 de Dez. 2019.

11 Disponivel em: https://www.atlasofplaces.com/architecture/ neue-nationalgalerie/\#figure-12. Acesso em: 01 de Dez. 2019.

12 Disponível em: https://pt.wikiarquitectura.com/ constru\%C3\%A7\%C3\%A3o/neue-nationalgalerie2/\#6-nationalgalerie. Acesso em: 01 de Dez. 2019.

13 Disponivel em: http://www.vilanovaartigas.com/cronologia/ projetos/casinha Acesso em: 01 de Dez. 2019.

14 Disponível em: https://www.archdaily.com.br/br/769052/ classicos-da-arquitetura-ginasio-de-guarulhos-vilanovaartigas-e-carlos-cascaldi/558991f7e58ecef4b500014aclassicos-da-arquitetura-ginasio-de-guarulhos-vilanovaartigas-e-carlos-cascaldi-foto. Acesso em: 01 de Dez. 2019.

15 Disponível em: https://www.archdaily.com.br/br/769052/ classicos-da-arquitetura-ginasio-de-guarulhos-vilanovaartigas-e-carlos-cascaldi/558992f8e58ece1c290001

3e-classicos-da-arquitetura-ginasio-de-guarulhos-vilanovaartigas-e-carlos-cascaldi-foto. Acesso em: 01 de Dez. 2019.

16 Disponível em: https://www.archdaily.com.br/br/769052/ classicos-da-arquitetura-ginasio-de-guarulhos-vilanovaartigas-e-carlos-cascaldi/55899302e58ece1c290001 3f-classicos-da-arquitetura-ginasio-de-guarulhos-vilanovaartigas-e-carlos-cascaldi-foto.Acesso em: 01 de Dez. 2019.

\section{NOTAS 3}

'Disponível em: https://www.archdaily.com.br/br/01-94257/ classicos-da-arquitetura-frederick-c-robie-house-slashfrank-Iloyd-wright/51089db9b3fc4b276d000169-classicosda-arquitetura-frederick-c-robie-house-slashfrank-lloyd-wright-planta-2-degrees-pavimento. Acesso em: 01 de Dez. 2019.

1 Disponível em: http://enciclopedia.itaucultural org.br/pessoa8581/antonio-henriqueamaral. Acesso em: 10 de Nov. 2019

2 Disponível em: http://www.stephan-schafer.com/ restauro.php. Acesso em: 15 de Jan. 20.

3 Disponível em: https://sao-paulo.estadao. com.br/noticias/geral,a-historia-do-jardimamerica,1800919. Acesso em: 1 de Dez. 2019.

4 Disponivel em: https://www.archdaily.com.br/br/877675/ classicos-da-arquitetura-camara-municipal-de-saynatsaloalvar-aalto/56de40fce58ece683d00009f-ad-classicssaynatsalo-town-hall-alvar-aaltoAcesso em: 01 de Dez. 2019.

5 Disponível em: https://www.averyreview.com/issues/8/ architecture-inspirited. Acesso em: 01 de Dez. 2019.

6 Disponivel em: https://en.wikiarquitectura.com/ building/bacardi-office-building-in-santiago-decuba/\#bacardi-pa. Acesso em: 01 de Dez. 2019.

7 Disponível em: https://en.wikiarquitectura.com/ building/bacardi-office-building-in-santiago-decuba/\#bacardi-plat. Acesso em: 01 de Dez. 2019.

18 Disponível em:http://commoestudio. com/2016/09/12/iconos-la-arquitectura-la-casafarnsworth/. Acesso em: 01 de Dez. 2019.

19 Disponivel em: https://pt.slideshare.net/4kks/plan-ofparliament-building-chandigarh-lecorbusier. Acesso em: 01 de Dez. 2019.

20 Disponível em: https://www.flickr.com/photos/ stankuns/9780398685. Acesso em: 01 de Dez. 2019.

21 Disponível em: http://www.arquiteturabrutalista.com.br/ fichas-tecnicas/DW\%201960-46/1960-46-fichatecnica. htm. Acesso em: 01 de Dez. 2019. 


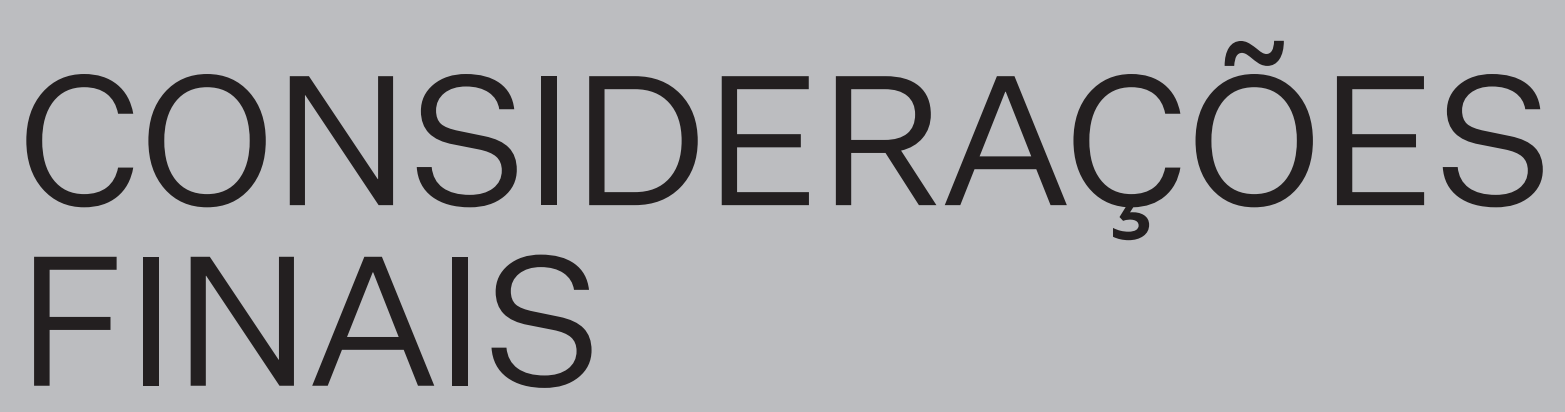


As pesquisas relacionadas à obra de Fábio Penteado se reduzem a duas publicações dedicadas exclusivamente à sua obra: o livro Fábio Penteado - Ensaios de Arquitetura, de 2002, organizado pelo próprio arquiteto; e a tese de doutorado, fruto de uma ampla pesquisa desenvolvida por Ivo Giroto pela Universidade Politécnica da Catalunha, intitulada $A$ praça é o povo. Intenção, projeto e multidão na arquitetura de Fábio Moura Penteado (2013). Além disso, a iniciativa de Adriana Penteado em fundar o Arquivo Fábio Penteado, com o objetivo de catalogar, restaurar e promover a pesquisa do acervo relativo à obra de seu pai, constitui uma das ações mais importantes dentro do panorama da arquitetura nacional e se tornou fundamental para a realização deste trabalho.

A presente dissertação parte das pesquisas anteriormente desenvolvidas para realizar um levantamento e análise de forma centrípeta em torno do projeto e obra do edifício-sede da Sociedade Harmonia de Tênis. Inicialmente, com o auxílio da equipe do Arquivo Fábio Penteado, foram organizados os documentos e desenhos relacionados diretamente à obra. Esta etapa inicial indicou a necessidade da ampliação da pesquisa com o objetivo de revelar os propósitos que conceberam o projeto.

A partir da análise do contexto histórico é possível sugerir o papel fundamental do engajamento das políticas públicas que promoveram a arquitetura, para a consolidação das vanguardas modernas carioca e paulista. Estes grupos, além de evidente talento profissional, estiveram vinculados a uma pesquisa em torno do desenvolvimento de uma arquitetura nacional e de importantes conquistas sociais.

Em São Paulo, os arquitetos estiveram apoiados pelo governo estadual durante o Programa de Ação do Governo Carvalho Pinto - PAGE (1959-1963) e por parte das elites econômicas que formaram uma importante base de clientes. O principal mentor do grupo, Vilanova Artigas, atuou para a formação de jovens arquitetos que responderam às encomendas, frequentemente de forma inovadora e associada à tecnologia nacional mais avançada e disponível naquele momento.

O loteamento do Jardim América, em que se situa o Clube Harmonia, foi projetado para se tornar um dos bairros de moradia da elite econômica da cidade. Seu traçado, que remete ao urbanismo dos subúrbios anglo-americanos, possuía amplos jardins públicos no interior de algumas de suas quadras. Estes jardins não se perpetuaram, devido aos encargos de suas manutenções, ao lado da falta de interesses por estes bens comuns da vizinhança, tornando-se lotes privados. A área na qual a Sociedade Harmonia de Tênis se instalou, preservou o seu uso de lazer, embora restrito aos associados do clube.

O Harmonia promoveu ao longo de sua existência ao menos três concursos para a construção de sua sede. O último, de 1964, foi vencido por Penteado, Paesani e Tamaki. O edifício tornou-se uma das obras mais representativas da arquitetura de seu tempo, por reunir estratégias projetuais alinhadas a esta vanguarda paulista e ser construído com exímia qualidade técnica, o que motivou o seu tombamento pelo CONDEPHAAT, no ano de 1992. Este foi um dos motivos que preservou a sua arquitetura em bom estado até os dias de hoje, após 50 anos de sua inauguração, possibilitando a verificação in loco das estratégias de projeto aplicadas à obra construída.

Em uma análise sobre a arquitetura moderna paulista, Czajkowski argumenta que o Harmonia "é o desmistificador da pecha de inviabilidade funcional e gratuidade técnica que atinge essa tendência como um todo, e lhe empresta uma maturidade que a salva de ser justificada antes de mais nada como um exercício ideológico."1

Penteado concebeu um edifício como "uma praça confortável para duas ou duas mil pessoas", os ideais que fundamentaram o projeto, com "intenções humanísticas de grande beleza"2, produziram um espaço ímpar na cidade de São Paulo desfrutado por um pequeno grupo de pessoas. Embora as evidentes limitações do programa contribuam com a segregação social - em oposição ao ideal de praça -, ainda subordinado aos costumes da época, na qual havia uma separação ainda mais severa entre o cliente e os empregados, Penteado foi capaz de conceber um espaço para o uso coletivo que potencializa o encontro e a convivência.

A vanguarda moderna paulista vem sendo objeto de estudo de inúmeras pesquisas acadêmicas, com especial atenção aos seus maiores expoentes: Vilanova Artigas e Paulo Mendes da Rocha. A presente dissertação revela a oportunidade de investigação não apenas do edifício-sede da Sociedade Harmonia de Tênis, mas também dos demais arquitetos e obras contemporâneas ao período.

\section{NOTAS}

1 (PENTEADO, 1998, p. 175)

2 (PENTEADO, 1998, p. 19) 


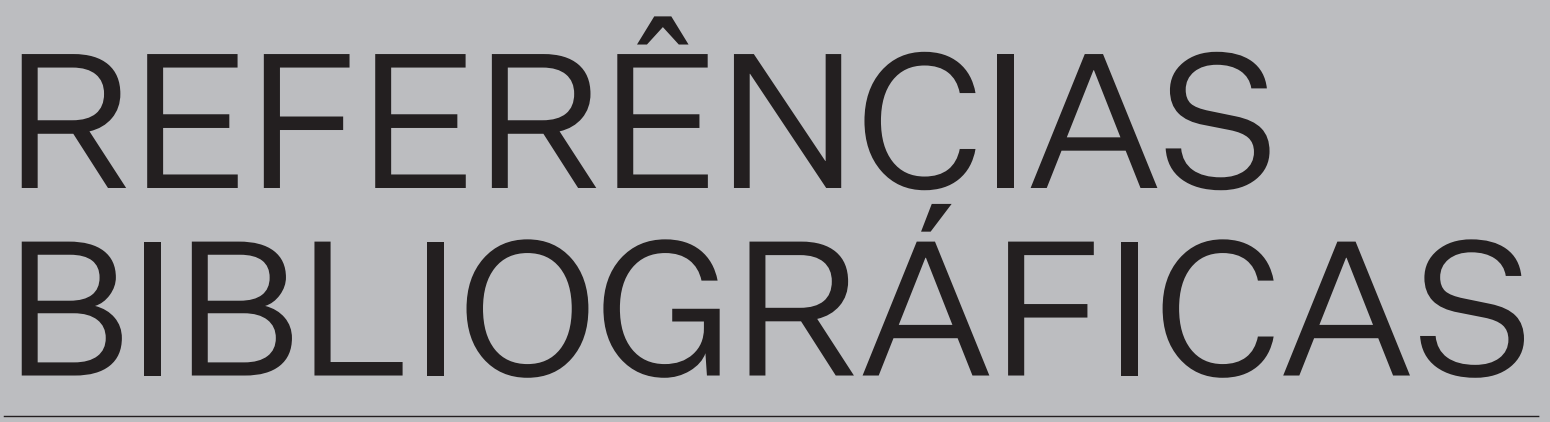




\section{PUBLICAÇÕES}

ALMEIDA, Deborah Sandes de. Companhia City além dos rios: os bairros-jardins na zona norte de São Paulo (1975-1992). Trabalho apresentado no XV Seminário de História da Cidade e do Urbanismo, Rio de Janeiro, 2018.

ANDRADE, Carlos Roberto Monteiro de. Jardim América: a arquitetura do primeiro bairro-jardim de São Paulo. Arquitextos, São Paulo, ano 1, n. 006.01, Vitruvius, jun. $2002<$ https://www.vitruvius.com.br/revistas/read/ resenhasonline/01.006/3240.> Acesso em: 08 de Out. 2019

ANDREOLI, Elisabetta; FORTY, Adrian (org.) Arquitetura moderna brasileira. Londres: Phaidon Press Limited, 2004.

ANELLI, Renato; GUERRA, Abílio; KON, Nelson. Rino Levi: Arquitetura e cidade. São Paulo: Romano Guerra Editora, 2001.

AQUINO, Flávio. Max Bill critica a nossa moderna arquitetura. Rio de Janeiro: Manchete, p. 38-39, jun. 1953.

ARTIGAS, Rosa Camargo et al (ed.). Vilanova Artigas: arquitetos brasileiros. São Paulo, Instituto Lina Bo e P. M. Bardi e Fundação Vilanova Artigas, 1997.

ARTIGAS, Rosa Camargo (org.). Paulo Mendes da Rocha: projetos 1999-2006. Tradução Anthony Doyle. São Paulo: Cosac \& Naify, 2007. . (org.). Paulo Mendes da Rocha. 2 edição. São Paulo: Cosac \& Naify, 2002.

ARTIGAS, João Batista Vilanova. Caminhos da Arquitetura. São Paulo: Cosac \& Naify. 2004.

ARGAN, Giulio Carlo. Arte Moderna. São Paulo: Cia. das Letras, 1992.

BACELLI, Roney.Jardim América. São Paulo: Prefeitura do Município de São Paulo, Secretaria Municipal de Cultura, Departamento de Patrimônio Histórico, Divisão do Arquivo Histórico, 1982.

BAROSSI, Antonio Carlos (org.). O edifício da FAU-USP de Vilanova Artigas. São Paulo: Editora da Cidade, 2016.

Ensino de projeto na FAU-USP: Faculdade de Arquitetura e Urbanismo da Universidade de São Paulo. 2005. Tese (Doutorado em Estruturas Ambientais Urbanas) Faculdade de Arquitetura e Urbanismo, Universidade de São Paulo, São Paulo, 2005.
BAXANDALL, Michael. Padrões de intenção: a explicação histórica dos quadros. São Paulo: Cia.das Letras, 2008.

BLASER, Werner. Mies Van der Rohe. 2 a edição. Barcelona: Editorial Gustavo Gili, 1976.

BOESIGER, Willy (ed.) Le Corbusier: Oeuvre Complète en 8 volumes. 7a edição. Basel: Birkhauser Publishers, 2006.

BROADBENT, Geoffrey. Diseño arquitetónico: arquitectura y ciencias humanas. Barcelona: Gustavo Gili, 1971.

BROADBENT, Geoffrey et al. Metodología del Diseño Arquitectónico. Barcelona: Gustavo Gili, 1971.

BRUAND, Yves. Arquitetura Contemporânea no Brasil. São Paulo: Ed. Perspectiva, 2008.

BUZZAR, Miguel Antonio; CAMARGO, Mônica Junqueira de; CORDIDO, Maria Tereza R. L. B. Os significados da mudança de paradigma arquitetônico advindo com o Plano de Ação de Governo de Estado/SP (PAGE) na gestão Carvalho Pinto (1959-1963). Trabalho apresentado no 11o seminário DOCOMOMO Brasil, Recife, 2016.

CAMARGO, Mônica Junqueira de. Princípios da arquitetura moderna na obra de Oswaldo Arthur Bratke. 2000. Tese (Doutorado em Arquitetura e Urbanismo). Faculdade de Arquitetura e Urbanismo, Universidade de São Paulo, 2000.

.Fábio Penteado: Arquitetura de integração. Revista AU. São Paulo. n105, dez 2002. . Escola Paulista, Escola Carioca: Algumas considerações. Trabalho apresentado no 13올 seminário DOCOMOMO Brasil, Salvador, 2019. . De Architectura, Vitrúvio, Edição de 1586: A curiosa trajetória da Iugoslávia à biblioteca da FAU-USP. Revista da Pós. São Paulo. V.17, no27 especial, p. 10-24, jun 2010.

. Inventário dos bens culturais relativos ao Plano de Ação do governo Carvalho Pinto (1959-1963). Revista CPC. São Paulo. no22 especial, p. 164-203, jul 2016.

CONTIER, Felipe de Araujo. O edificio da Faculdade de Arquitetura e Urbanismo na Cidade Universitária: projeto e construção da escola de Vilanova Artigas. 2015. Tese (Doutorado em Teoria e História da Arquitetura e do Urbanismo). Instituto de Arquitetura e Urbanismo, Universidade de São Paulo, São Carlos, 2015.

COSTA, Angélica Irene da. As obras escolares do Plano de Ação do Governo do Estado (PAGE): A educação em novas formas. 2015. Tese (Doutorado em Teoria e História da Arquitetura e do Urbanismo). Instituto de Arquitetura e Urbanismo, Universidade de São Paulo, São Carlos, 2015. 
COTRIM, Marcio. O papel da casa Mario Taques Bittencourt na definição da obra de Vilanova Artigas. Revista Risco. São Carlos. no21, p. 96-107, 2015.

- Mies e Artigas: a delimitação do espaço através de uma única cobertura. Arquitextos, São Paulo, ano 09, Vitruvius, mai.2009 <https://www.vitruvius.com. br/revistas/read/arquitextos/09.108/52> Acesso em: 04 de Ago.2019.

DEDECCA, Paula Gorenstein. Sociabilidade, crítica e posição: o meio arquitetônico, as revistas especializadas e o debate do moderno em São Paulo (1945-1965). 2012. Dissertação (Mestrado em História e Fundamentos da Arquitetura e do Urbanismo). Faculdade de Arquitetura e Urbanismo, Universidade de São Paulo, São Paulo, 2012.

FIALHO, Valéria Cássia dos Santos. Arquitetura, texto e imagem: a retórica da representação nos concursos de arquitetura. 2007. Tese (Doutorado em Projeto de Arquitetura). Faculdade de Arquitetura e Urbanismo, Universidade de São Paulo, São Paulo, 2007.

FAGGIN, Carlos Augusto Mattei. Carlos Millan: Itinerário profissional de um arquiteto paulista. Tese (Doutorado em Arquitetura e Urbanismo). Faculdade de Arquitetura e Urbanismo, Universidade de São Paulo, São Paulo, 1992.

FRAMPTON, Kenneth. História critica da arquitetura moderna. São Paulo: Martins Fontes, 1997.

GIROTO, Ivo Renato. A praça é o povo: Intenção, projeto e multidão na arquitetura de Fábio Moura Penteado. 2013. Tese (Doutorado em Teoria e História da Arquitetura). Departamento de Composição Arquitetônica, Universidade Politécnica da Catalunha, Barcelona, 2013.

- A praça é o povo: a arquitetura de Fábio Penteado. Trabalho apresentado no 8o seminário DOCOMOMO Brasil, Rio de Janeiro, 2009.

. Arquitetura para a multidão: explosão demográfica na arquitetura de Fábio Penteado. Trabalho apresentado no 9o seminário DOCOMOMO Brasil, Brasília, 2011.

. Metadesenho: uma análise sobre o projeto da Sede Social do Clube Harmonia, de Fábio Penteado. Revista Projetar. Natal. V.1, n³, p.76-86, dez 2016.

GOODWIN, Philip Lippincott. Brazil builds: architecture new and old, 1652-1942. Nova York: The Museum of Modern Art, 1943. Catálogo da exposição. 13 jan - 28 fev, 1943, MOMA.
GORDINHO, Margarida Cintra; MARTINS, Ana Luiza. Memória do Harmonia. São Paulo: Marca D’Água, 1993.

GOTO, Sheila Naomi; MONTEIRO, Ana Maria

Reis de Goes. A aplicação dos conceitos de "garden-city" no bairro do Jardim América. Trabalho apresentado no XVIII Enanpur, Natal, 2019.

HERTZBERGER, Herman. Lições de arquitetura. São Paulo, Martins Fontes, 1996.

IWAMIIZU, Cesar Shundi. A estação rodoviária de Jaú e a dimensão urbana da arquitetura. 2008. Dissertação (Mestrado em Projeto de Arquitetura). Faculdade de Arquitetura e Urbanismo, Universidade de São Paulo, São Paulo, 2008.

KAMITA, João Masao. Vilanova Artigas. Tradução Jeffery Hessney. São Paulo: Cosac \& Naify Edições, 2000.

KOOP, Anatole. Quando o moderno não era um estilo e sim uma causa. São Paulo: Nobel/Edusp, 1990.

KOURY, Ana Paula. Grupo Arquitetura Nova. 1999. Dissertação (Mestrado em Arquitetura e Urbanismo). Escola de Engenharia de São Carlos, Universidade de São Paulo, São Carlos, 1999.

LEITE, Lucas Löff Ferreira. Paulo Mendes da Rocha em solo: o projeto do edificio e seus redesenhos topográficos. 2019. Dissertação (Mestrado em teoria, história e crítica da arquitetura). Programa de pesquisa e pós graduação em arquitetura, UFRGS, 2019.

LIMA JUNIOR, Marcio Antonio de. O traço moderno na arquitetura religiosa paulista. 2016. Dissertação (Mestrado em História e Fundamentos da Arquitetura e Urbanismo). Faculdade de Arquitetura e Urbanismo, Universidade de São Paulo, São Paulo, 2016.

LOPES, Maria Ester de Araújo. Conhecer os Bairros-Jardins paulistanos confinados nos arquivos: o caso do Jardim América. 2016. Dissertação (Mestrado em Arquitetura, Tecnologia e Cidade). UNICAMP, Campinas, 2016.

MARGOTTO, Luciano. Lições da Arquitetura: leituras a partir de poéticas. 2016. Tese (Doutorado em História e Fundamentos da Arquitetura e Urbanismo). Faculdade de Arquitetura e Urbanismo, Universidade de São Paulo, São Paulo, 2016.

MARKUN, Paulo. Jornal Des Harmonia. São Paulo, agosto, 1991. 
MATERA, Sergio. Carlos Millan: um estudo sobre a produção em arquitetura. 2005. Dissertação (Mestrado em História e Fundamentos da Arquitetura e Urbanismo). Faculdade de Arquitetura e Urbanismo, Universidade de São Paulo, São Paulo, 2005.

MINDLIN, Henrique Ephim. Arquitetura moderna no Brasil. Tradução Paulo Pedreira. 2a edição. Rio de Janeiro: Aeroplano Editora e IPHAN, 2000.

MONTANER, Josep Maria. Después del Movimiento Moderno. Arquitectura de la segunda mitad del siglo XX. Barcelona: Gustavo Gili, 1993.

NAKANDAKARE, Fernando Shigeo. O Instituto de Arquitetos do Brasil na disseminação da profissão do arquiteto moderno entre 1945-1969. 2018. Dissertação (Mestrado em Arquitetura, tecnologia e cidade). Faculdade de Engenharia Civil, Arquitetura e Urbanismo, Unicamp, Campinas, 2018.

NASCIMENTO, Flávia Brito do. Blocos de memórias: habitação social, arquitetura moderna e patrimônio cultural. 2011. Tese (Doutorado em Habitat). Faculdade de Arquitetura e Urbanismo, Universidade de São Paulo, São Paulo, 2011.

NESBITT, Kate. Theorizing a new agenda for architecture. An anthology of architectural theory 1965-1995. New York: Princeton Architectural Press, 1996.

OKSMAN, Silvio. Preservação do patrimônio arquitetônico moderno: a FAU de Vilanova Artigas. 2010. Dissertação (Mestrado em Projeto, espaço e cultura). Faculdade de Arquitetura e Urbanismo, Universidade de São Paulo, São Paulo, 2010.

PAESANI, Alfredo. Entrevista: Alfredo Paesani. Projeto Design, São Paulo, edição 299, janeiro, 2005. Disponível em <https://www.arcoweb.

com.br/projetodesign/entrevista/alfredopaesani-01-01-2005> Acesso em: 14 de Ago. 2019.

PENTEADO, Fábio. Entrevista com Fábio Penteado. Arquitetura Revista, Rio de Janeiro, V.1, no1, p.12-29, setembro, 1983.

Entrevista: Fábio Penteado. Projeto Design, São Paulo, nำ290, abril, 2004. Disponível em $<$ https://www.arcoweb.com.br/

projetodesign/entrevista/fabio-penteado-comopaisagem-22-04-2004>. Acesso em: 12 de Ago. 2018. . Fábio Penteado: ensaios de arquitetura. São Paulo: Empresa das Artes, 1998.
PERRONE, Rafael A. Cunha. Arquitetura moderna em Brasil: a Escola Paulista. Palestra em Xornadas de Arquitetura Brasileña. ETSA Universidade da Coruña, 2010. . Desenho como signo da arquitetura. 1993. Tese (Doutorado em Arquitetura e Urbanismo). Faculdade de Arquitetura e Urbanismo, Universidade de São Paulo, São Paulo, 1993.

. El proyecto como investigación académica de posgrado. Anais da IV Jornadas Internacionales sobre investigación en Arquitectura y Urbanismo. Valencia: General de Ediciones de Arquitectura, 2010.

. Os croquis e os processos de projeto de arquitetura. 2008. Tese de livre-docência. Faculdade de Arquitetura e Urbanismo, Universidade de São Paulo, São Paulo, 2008.

PISANI, Daniele. Paulo Mendes da Rocha: Obra completa. Tradução Alexandre Salvaterra. São Paulo: Gustavo Gili, 2013.

PRÓSPERO, Vitor. Clubes privados, desenho e cidade dos anos 1960: o caso da Sociedade Harmonia de Tênis em São Paulo. Trabalho apresentado no 60 seminário DOCOMOMO São Paulo, São Paulo, 2018.

ROSSI, Aldo. A arquitetura da cidade. São Paulo: Martins Fontes, 1995.

SANTIAGO, Stella Elia Martins. Antonio Maluf: arte concreta na arquitetura moderna paulista (1960/70). 2009. Dissertação (Mestrado em História e Fundamentos da Arquitetura e Urbanismo). Faculdade de Arquitetura e Urbanismo, Universidade de São Paulo, São Paulo, 2009.

SANTOS, Luciene Ribeiro dos. Os professores de projeto da FAU-USP (1948-2018): esboços para a construção de um centro de memória. 2018. Dissertação (Mestrado em Design e Arquitetura). Faculdade de Arquitetura e Urbanismo, Universidade de São Paulo, São Paulo, 2018.

SANTOS, Valéria Cássia dos. Concursos de Arquitetura em São Paulo. 2002. Dissertação (Mestrado em Arquitetura e Urbanismo). Faculdade de Arquitetura e Urbanismo, Universidade de São Paulo, São Paulo, 2002.

SCULLY, Vincent. Arquitetura Moderna: A arquitetura da democracia. São Paulo: Cosac \& Naify, 2002.

SEGAWA, Hugo. Arquiteturas no Brasil: 19001990. 3a edição. São Paulo: Edusp, 2010.

. Prelúdio da Metrópole: Arquitetura e Urbanismo em São Paulo na passagem do século XIX ao $X X$. Cotia: Ateliê Editorial, 2000. 
SILVA, Helena A. Ayoub. Abrahão Sanovicz: o projeto como pesquisa. 2004. Tese (Doutorado em Arquitetura e Urbanismo). Faculdade de Arquitetura e Urbanismo, Universidade de São Paulo, São Paulo, 2004.

SNOZZI, Luigi. Luigi Snozzi, Progetti e Architetture 1957-1984. Milão: Electa, 1984.

SPIRO, Annette. Paulo Mendes da Rocha: Bauten und Projekte. Zurich: Verlag Niggli AG Sulgen, 2002.

SOARES, Luciano Margotto. $A$ arquitetura de Álvaro Siza: três estudos de caso. 2001. Dissertação (Mestrado em Arquitetura e Urbanismo). Faculdade de Arquitetura e Urbanismo, Universidade de São Paulo, São Paulo, 2001.

TOLEDO, Benedito Lima de. São Paulo: três cidades em um século. São Paulo: Livraria Duas Cidades, 1983.

VALDES, Rodrigo Millan. Arquitetura esportiva no interior do Estado de São Paulo: os projetos de Ícaro de Castro Mello entre 1950-1964. Trabalho apresentado no VI Encontro da Associação Nacional de Pesquisa e Pós-Graduação em Arquitetura e Urbanismo, Porto Alegre, 2016.

VESPUCCI, Ana Cândida. 60 anos de Harmonia: 0 tênis no Brasil. São Paulo: Empresa das Artes, 1990.

WISNIK, Guilherme. Artigas e a dialética dos esforços. Revista Novos Estudos. São Paulo. no102, p.153169, jul 2015.

WOLFF, Silvia Ferreira Santos. Jardim América: O primeiro bairro-jardim de São Paulo e sua arquitetura. São Paulo: Edusp, 2001.

.Jardim América: da casa de alguns a território preservado da metrópole. Revista CPC. São Paulo. no22 especial, p.217-232, abr 2017.

XAVIER, Alberto. Depoimento de uma geração: Arquitetura moderna brasileira. São Paulo: Cosac \& Naify, 2003.

XAVIER, Alberto; LEMOS, Carlos; CORONA, Eduardo. Arquitetura moderna paulistana. São Paulo: Pini, 1983.

YOSHIDA, Celia Ballario, et al. Henrique Ephim Mindlin, o homem e o arquiteto. São Paulo: Instituto Roberto Simonsen / Federação e Centro das Indústrias do Estado de São Paulo, 1975.

ZEIN, Ruth Verde. Arquitetura brasileira, escola paulista e as casas de Paulo Mendes da Rocha. 2000. Dissertação (Mestrado em Arquitetura). UFRGS, Porto Alegre, 2000.
_Arquitetura da Escola Paulista Brutalista: 1953-1973. 2005. Tese (Doutorado em Arquitetura). UFRGS, Porto Alegre, 2005.

ZEVI, Bruno. Saber ver a arquitetura. São Paulo: Martins Fontes, 1992.

\section{PERIÓDICOS}

ACRÓPOLE, São Paulo: Editora Gruenwald Ltda. . no260, maio 1960, p. 191-197. Projeto para sede social de clube. .. n-340, junho 1967, p. 30-33. Sede social de clube. . no377, setembro 1970, p. 12. Sobre escolas....

Harmonia. .n-384, maio 1971, p. 12-21. Sede do

O DIRIGENTE CONSTRUTOR, São Paulo, V.2, no11, p. 10-18, setembro 1966. Projeto Harmonia é sintese de arte e técnica.

VISÃO, São Paulo, agosto 1960, p.33. Harmonia com formas novas.

\section{SITES ACESSADOS}

www.archdaily.com www.archdaily.com.br www.averyreview.com www.arcoweb.com.br www.atlasofplaces.com www.commoestudio.com www.enciclopedia.itaucultural.org.br www.ibge.gov.br www.sao-paulo.estadao.com.br www.pt.slideshare.net www.vilanovaartigas.com www.vitruvius.com.br www.en.wikiarquitectura.com 


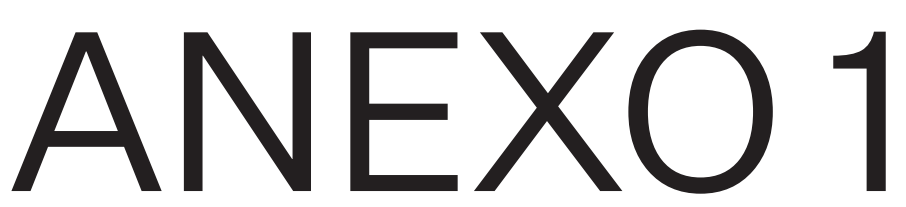

\section{LISTA DE DESENHOS SOB GUARDA DA SOCIEDADE HARMONIA DE TÊNIS}

\begin{tabular}{|c|c|c|c|c|}
\hline & FOLHA & TÍTULO & DATA & ESCALA \\
\hline Aprovação PMSP & 1 & Projeto de prefeitura & $31 / 8 / 1965$ & $1: 100$ \\
\hline Aprovação PMSP & 2 & Projeto de prefeitura & $31 / 8 / 1965$ & $1: 100$ \\
\hline Aprovação PMSP & 2 (cópia) & Projeto de prefeitura & $31 / 8 / 1965$ & $1: 100$ \\
\hline Aprovação PMSP & 3 & Projeto de prefeitura & $31 / 8 / 1965$ & $1: 100$ \\
\hline Aprovação PMSP & 4 & Projeto de prefeitura & $31 / 8 / 1965$ & $1: 100$ \\
\hline Aprovação PMSP & 4 (cópia) & Projeto de prefeitura & $31 / 8 / 1965$ & $1: 100$ \\
\hline Aprovação PMSP & $\mathrm{S} / \mathrm{N}$ & Salão de Jogos - Portas & $\mathrm{N} / \mathrm{C}$ & $1: 50$ e $1: 20$ \\
\hline Executivo & 33.13 & Sanitários Salão de jogos & $\mathrm{N} / \mathrm{C}$ & $1: 50$ \\
\hline Executivo & $\mathrm{S} / \mathrm{N}$ & Auditório & $\mathrm{N} / \mathrm{C}$ & $1: 50$ \\
\hline Executivo & 3.3 .16 & Vidros - Vedação na entrada e secretaria & $\mathrm{N} / \mathrm{C}$ & $1: 50$ \\
\hline Executivo & 2 & Planta de Pisos cotas 90 e - 65 & $18 / 10 / 1965$ & $1: 50$ \\
\hline Executivo & D1 a D23 & $\begin{array}{l}\text { Detalhes: Escadas, Sanitários, Vidros, } \\
\text { Portas e Brise ( } 23 \text { folhas) }\end{array}$ & 1965 & $1: 20$ \\
\hline Executivo & 5 & Salão das crianças & $8 / 1965$ & $1: 100$ \\
\hline Executivo & 6 & Salão das crianças & $8 / 1965$ & $1: 100$ \\
\hline Executivo & $\mathrm{S} / \mathrm{N}$ & Sauna & $5 / 10 / 1965$ & $1: 50$ \\
\hline Pré-executivo & $\mathrm{S} / \mathrm{N}$ & Bar da Piscina & $26 / 10 / 1965$ & $1: 50$ \\
\hline Pré-executivo & $\mathrm{S} / \mathrm{N}$ & Movimento de terra & 1965 & $1: 100$ \\
\hline Execução & 3.3.8 & Peitoril de concreto cota 3,325 & $27 / 1 / 1967$ & $1: 50$ \\
\hline Execução & 4.34 & Bar do salão & 4/3/1966 & $1: 20$ e $1: 2$ \\
\hline Execução & D2 E D3 & Detalhes escada & $17 / 2 / 1967$ & !:10 \\
\hline Execução & 3.311 & Detalhes escada & $17 / 2 / 1967$ & $1: 20$ \\
\hline Execução & 3.3 .10 & Detalhes escada & $17 / 2 / 1967$ & $1: 50$ \\
\hline Execução & 1 & Sede provisória & 1965 & $1: 100$ \\
\hline
\end{tabular}




\begin{tabular}{|c|c|c|c|c|}
\hline & FOLHA & TÍTULO & DATA & ESCALA \\
\hline Execução & 6.13 & Estudo do portão rua Argentina & $13 / 10 / 1966$ & 1:20 e $1: 1$ \\
\hline Execução & $\mathrm{S} / \mathrm{N}$ & Apoio das poltronas auditorium & 1965 & $1: 20$ \\
\hline Execução & $\mathrm{S} / \mathrm{N}$ & Refeitório de funcionários & $16 / 6 / 1970$ & $1: 50$ \\
\hline Execução & 6.3 .3 & Controle de entrada da rua argentina & $13 / 9 / 1966$ & $1: 20$ \\
\hline Execução & 3 & Entrada portaria rua Canadá & 1965 & 1:100 \\
\hline Execução & 6 & Elevação da piscina & $18 / 10 / 1965$ & $1: 50$ \\
\hline Execução & 2 & Planta de piso | cota 90 e -65 & $18 / 10 / 1965$ & $1: 50$ \\
\hline Execução & 3 & Planta de piso | cota 242,5 / 332,5 / 390 & $18 / 10 / 1965$ & $1: 50$ \\
\hline Execução & 4 & Planta de cobertura | cota 790 & $4 / 11 / 1965$ & $1: 50$ \\
\hline Execução & $4 \mathrm{~A}$ & Planta de cobertura | cota 790 & $7 / 1 / 1966$ & $1: 50$ \\
\hline Execução & 5 & Cortes AA, DD, EE & $18 / 10 / 1965$ & $1: 50$ \\
\hline Execução & 6 & Cortes BB, CC & 18/10/1965 & $1: 50$ \\
\hline Execução & 7 & Elevações & $5 / 11 / 1965$ & $1: 50$ \\
\hline Execução & D1 & Auditorium & $23 / 10 / 1968$ & $1: 50$ \\
\hline Execução & D2 & Poltrona tipo 1 - Auditorium I planta e corte & $23 / 10 / 1968$ & $1: 5$ \\
\hline Execução & D3 & Poltrona tipo 1 - Auditorium / detalhe & $23 / 10 / 1968$ & $1: 2$ \\
\hline Execução & D4 & $\begin{array}{l}\text { Poltrona tipo } 1 \text { - Auditorium | } \\
\text { corte e perspectiva }\end{array}$ & $23 / 10 / 1968$ & $1: 5$ \\
\hline Execução & $\mathrm{S} / \mathrm{N}$ & Poltrona - Elevação & $\mathrm{N} / \mathrm{C}$ & 1:1 \\
\hline Execução & $\mathrm{S} / \mathrm{N}$ & Poltrona - Corte & $\mathrm{N} / \mathrm{C}$ & 1:1 \\
\hline Execução & $\mathrm{S} / \mathrm{N}$ & Perspectiva Sede & $\mathrm{N} / \mathrm{C}$ & $S / E$ \\
\hline Execução & $\mathrm{S} / \mathrm{N}$ & Porta salão de jogos & $2 / 10 / 1969$ & $1: 10$ e $1: 1$ \\
\hline Execução & $15 \mathrm{~A}$ & Cozinha inferior & $\mathrm{N} / \mathrm{C}$ & S/E \\
\hline Execução & $17 \mathrm{~A}$ & Elevação dos sanitários & $\mathrm{N} / \mathrm{C}$ & $S / E$ \\
\hline
\end{tabular}



